VIVIAN ANNE FRAGA DO NASCIMENTO ARRUDA

\title{
A FLORESCÊNCIA DA COOPERAÇÃO JURÍDICA INTERNACIONAL NO COMBATE AOS CARTÉIS TRANSFRONTEIRIÇOS: A EXPERIÊNCIA BRASILEIRA E REFLEXÕES PARA SEU APERFEIÇOAMENTO
}

\author{
DISSERTAÇÃO DE MESTRADO \\ ÁREA DE CONCENTRAÇÃO: DIREITO INTERNACIONAL E COMPARADO
}

Orientador: Professor Doutor Wagner Luiz Menezes Lino

FACULDADE DE DIREITO DA UNIVERSIDADE DE SÃO PAULO

SÃO PAULO

2013 
VIVIAN ANNE FRAGA DO NASCIMENTO ARRUDA

\section{A FLORESCÊNCIA DA COOPERAÇÃO JURÍDICA INTERNACIONAL NO COMBATE AOS CARTÉIS TRANSFRONTEIRIÇOS: A EXPERIÊNCIA BRASILEIRA E REFLEXÕES PARA SEU APERFEIÇOAMENTO}

Dissertação de Mestrado apresentada à Comissão de Pós-Graduação da Faculdade de Direito da Universidade de São Paulo, como requisito parcial à obtenção do Grau de Mestre em Direito Internacional sob a orientação do Professor Doutor Wagner Luiz Menezes Lino.

FACULDADE DE DIREITO DA UNIVERSIDADE DE SÃO PAULO

SÃO PAULO 
Nome: Vivian Anne Fraga do Nascimento Arruda

Título: A Florescência da Cooperação Jurídica Internacional no Combate aos Cartéis Transfronteiriços: a Experiência Brasileira e Reflexões para o seu Aperfeiçoamento

Dissertação de Mestrado apresentada à Comissão de Pós-Graduação da Faculdade de Direito da Universidade de São Paulo, como requisito parcial à obtenção do Grau de Mestre em Direito Internacional.

Aprovado em:

Banca Examinadora

$\operatorname{Prof}(\mathrm{a}) . \operatorname{Dr}(\mathrm{a})$.

Instituição:

Julgamento:

Assinatura:

Prof(a). Dr(a).

Instituição:

Julgamento:

Assinatura:

Prof(a). Dr(a).

Instituição:

Julgamento:

Assinatura:

Prof(a). Dr(a).

Instituição:

Julgamento: Assinatura: 


\section{AGRADECIMENTOS}

A Florescência não foi por mim escolhida, ao contrário, me escolheu. Ela me elegeu enquanto sua autora quando fui arrebatada por um apaixonamento científico indescritível, um amor ao título em si e à pesquisa proposta pelo trabalho. Ela simplesmente floresceu em meu intelecto. Inicialmente, contudo, tal eleição foi um pouco atribulada, pois meu primeiro projeto era outro, versava sobre o estudo da persecução na esfera civil dos condenados pelo Conselho Administrativo de Defesa Econômica por infrações à Lei Brasileira de Defesa da Concorrência. Porém, a atribulada conjuntura da minha vida profissional me convidando a integrar a equipe de Antitruste de uma das maiores bancas de advocacia do Brasil e todas as responsabilidades e esforços inerentes à posição, além da possibilidade de reservar referido tema para um trabalho posterior, de doutorado, ante a complexidade e ineditismo que a matéria comporta, foram os fortes apelos da Florescência em detrimento do outro trabalho. Além de todos os outros créditos que meu marido teve e tem em minha vida, o título Florescência deve ser creditado a ele, pois teve inspiração em seu doutoramento ${ }^{1}$. É ao meu marido, assim, meu primeiro agradecimento, por me inspirar intelectualmente, por me aceitar e me amar, e, sobretudo, por me dar seu alento, sempre que preciso. E, preciso sempre. Aos meus pais, João e Helena, meus heróis, meus maiores incentivadores, meus exemplos de garra, retidão, amor incondicional à família. À minha sogra Maria Arminda, grande estímulo intelectual em minha vida acadêmica, por seu valioso apoio, fundamental motivação e por sua ternura. Ao professor Wagner Luiz Menezes Lino, modelo de orientador, sempre presente, rigoroso quanto ao cumprimento dos compromissos acadêmicos e mais ainda quanto à qualidade do trabalho. Seu incessante empenho e dedicação nas diversas análises deste trabalho, sua maneira com que me incentivou e me estimulou, me fizeram chegar muito mais preparada ao final deste caminho. Ao meu adorado filho Otávio, felicidade sem fim em minha vida. Seu nascimento no final da elaboração deste trabalho, foi o fruto mais doce da Florescência. Obrigada a Deus, minha fortaleza.

\footnotetext{
${ }^{1}$ Arruda, Jose Jobson do Nascimento. A florescência tardia: Bolsa de Valores de São Paulo e mercado global de capitais (1989-2000), 2011.
} 


\section{RESUMO}

ARRUDA, Vivian Anne Fraga do Nascimento. A Florescência da Cooperação Jurídica Internacional no Combate aos Cartéis Transfronteiriços: a Experiência Brasileira e Reflexões para o seu Aperfeiçoamento. 2013. 207 f. Dissertação (Mestrado) - Faculdade de Direito, Universidade de São Paulo, São Paulo, 2013.

O Direito Antitruste experimenta hoje uma verdadeira era dourada na qual a cooperação internacional entre os órgãos de defesa da concorrência e a aplicação de suas leis alcançaram níveis jamais vistos. Como efeito colateral do fenômeno "globalização", o qual marcou as últimas décadas pela expansão da economia de mercado, veio a internacionalização dos acordos entre concorrentes com vistas a limitar a concorrência. Os chamados cartéis, antes nacionais, passam a ter a dimensão dessa nova dinâmica da economia, a mundial. E os danos ao mercado, antes limitados a um território, passam a poder atingir dezenas de jurisdições. A partir desse introito, o objetivo dessa dissertação é oferecer ao leitor um quadro compreensivo da evolução da atuação das autoridades antitruste brasileiras na cooperação internacional de combate aos cartéis transnacionais, em termos normativos e na utilização na prática, considerando, sobretudo, o contexto do recente recrudescimento do instrumental persecutório das autoridades brasileiras de defesa da concorrência no combate às práticas anticompetitivas. Por meio de uma análise comparativa entre os acordos internacionais de cooperação mais sofisticados e os instrumentos cooperacionais existentes no Brasil à luz da sua florescente experiência, a dissertação procura identificar os elementos necessários para o aprofundamento da técnica cooperativa brasileira de combate aos cartéis transnacionais. Ou seja, intenta trazer elementos para a reflexão dos mecanismos cooperativos brasileiros para um combate mais efetivo à mais danosa infração à livre concorrência. Para tal análise comparativa, o centenário direito antitruste estadunidense é paradigma de direito estrangeiro, em especial porque alia a longa experiência jurídica nessa matéria a mecanismos bastante inovadores em relação ao sistema jurídico nacional. O presente trabalho tem também por escopo tratar dos principais temas que permeiam a discussão da cooperação internacional entre as agências de defesa da 
concorrência, passando pelo estudo dos conceitos de cooperação jurídica internacional; princípios do direito internacional público que regem a competência internacional dos Estados, incluindo a delimitação do escopo da cooperação em sede da aplicação extraterritorial do direito antitruste, noções de direito concorrencial, os instrumentos e mecanismos de cooperação internacional existentes, as melhores práticas, entre outros. Os desdobramentos das questões analisadas nesta reflexão se expressam em problemas jurídicos tanto de caráter geral quanto de ordem específica. De forma geral, impõe-se uma avaliação recapitulativa e analítica da natureza jurídica dos acordos de cooperação assinados pelo Brasil, de suas características e de sua utilização. Também se pretende avaliar o tratamento normativo dado aos cartéis e à questão da incidência extraterritorial da legislação antitruste brasileira e da legislação comparada, bem como do entendimento da jurisprudência (especialmente do CADE) sobre os principais temas que permeiam a pesquisa. No âmbito dos objetivos específicos, é necessário responder às seguintes perguntas: como a cooperação entre as agências de defesa da concorrência pode efetivamente auxiliar na aplicação de suas leis?; quais os limites e obstáculos dessa cooperação?; quais os tipos de cooperação disponíveis e quais deles fariam sentido para o Brasil na persecução de cartéis internacionais?; como o Brasil pode aperfeiçoar seu modelo jurídico-institucional de cooperação?

Palavras-chave:

Cooperação Internacional. Agências de defesa da concorrência. Cartéis internacionais. Direito Antitruste. 


\section{ABSTRACT}

ARRUDA, Vivian Anne Fraga do Nascimento. The Flowering of the Antitrust Cooperation in the fight against international cartels: Brazilian experience and remarks for its improvement, 2013. 207 f. Dissertação (Mestrado) - Faculdade de Direito, Universidade de São Paulo, São Paulo, 2013.

The Antitrust Law faces today a true golden age in which international cooperation among antitrust authorities and its enforcement have reached levels never seen before. As a side effect of the "globalization", the phenomenon that marked the past few decades by the world expansion of the economy, it came along the internationalization of agreements among competitors to restrain competition. Prior to that, the so-called cartels had then a national dimension, but along with the globalization, they now operate at a worldwide scale in this new dynamic of the world economy. And, the damages to the market, which was before limited to a single territory, now, reach dozens of jurisdictions. With that preamble into consideration, the goal of the present dissertation is offering the reader a comprehensive picture of the evolution of the Brazilian antitrust authorities on international cooperation in the fight of transnational cartels, both, in normative terms and in practice. That picture is especially important in light of the context of the recently enhanced Brazilian authorities instrumental competition in combating anti-competitive practices. Through a comparative assessment between the more sophisticated cooperation international agreements and the Brazilian cooperational instruments, the dissertation attempts to identify the essentials for the improvement of the Brazilian cooperative techniques in combating transnational cartels. That is, it brings elements to the reflection of the Brazilian cooperative mechanisms for a more effective combat of such damaging infringement to free competition. For the elaboration of said comparative assessment, the centennial USA antitrust law is the foreign law paradigm chosen, in particular because it combines the long legal experience in the matter and fairly innovative mechanisms in relation to the Brazilian legal system. The present work also deals with the most relevant themes that permeate the discussion of international cooperation among 
antitrust agencies, such as, the study of concepts of international legal cooperation; the public international law principles which govern the international jurisdiction of the States, including the extraterritorial application of antitrust law, relevant notions of competition law, international instruments and existing mechanisms for cooperation, best practices, among others. The unfolding of these relevant matters which are examined in the herewith reflection are expressed in legal problems of both general and specific orders. Generally, the work presents a summary and an analytical assessment of the legal nature of the cooperation agreements signed by Brazil, its characteristics, and its use. The work also aims at evaluating the regulatory treatment given to cartels and at addressing the question of the extraterritorial application of the Brazilian antitrust legislation and of comparative law, as well as at understanding the national case law (especially of CADE) on the main matters. With the specific objectives in mind, the present work deems necessary to respond to the following questions: How cooperation among the antitrust agencies can effectively enforce competition laws? What are the limits and obstacles of this cooperation? What types of cooperation are available and which ones make sense for Brazil in the prosecution of international cartels? How can Brazil enhance its legal and institutional model of cooperation?

Keywords:

International cooperation. Antitrust agencies. International cartels. Antitrust Law. 


\section{SUMÁRIO}

Introdução..................................................................................................................................................14

Capítulo I - Apontamentos conceituais e teóricos............................................................................21

Seção I - Referencial teórico: cooperação internacional latu sensu........................................21

1. Breve introdução ao tema: cooperação \& o contexto internacional ................................... 21

2. Surgimento do instituto e o conceito adotado por este trabalho........................................ 21

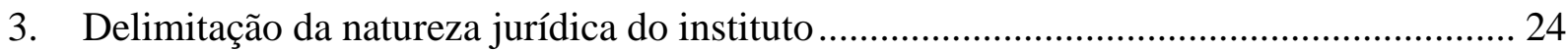

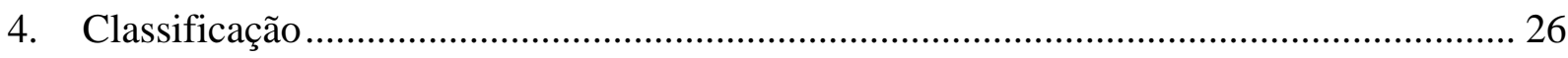

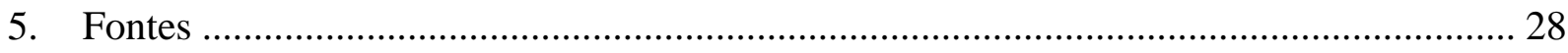

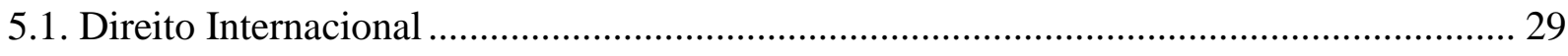

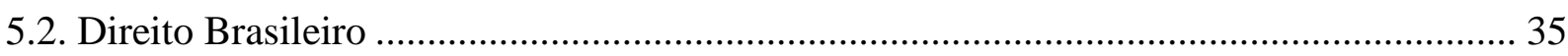

6. Procedimentos da cooperação jurídica internacional para fins de produção de prova....... 40

7. Direitos fundamentais: os limites da cooperação .............................................................. 42

Seção II - O Direito da Concorrência no Brasil ...................................................................... 46

1. Noções introdutórias sobre o Direito da Concorrência ........................................................ 46

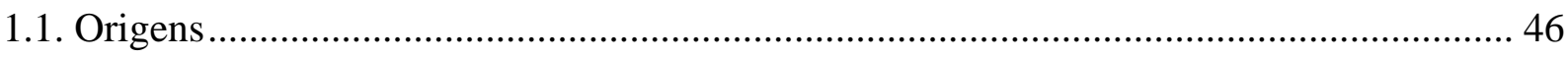

1.2. O bem tutelado pelo Direito Antitruste. Principais escolas: Harvard, Chicago e Ortoliberal 48

1.3. A evolução do Direito Antitruste no Brasil .................................................................. 52

2. O advento da Constituição Federal de 1998 ......................................................................... 57 
2.1. Contextualização constitucional do bem tutelado: princípios da Ordem Econômica e instrumentalidade da defesa da concorrência .......................................................................... 58

3. A Lei 8.884/1994: características gerais, esferas de atuação e autoridades responsáveis pela sua aplicação. Sua revogação pela Lei 12.529/11 ("Diploma Brasileiro Antitruste")...... 60

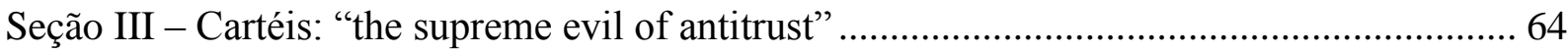

1. Nota introdutória e a classificação de cartel adotada por este trabalho................................ 64

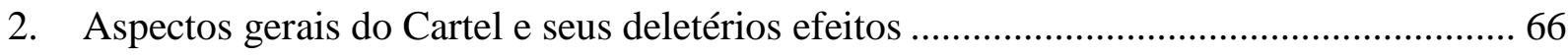

2.1. Conceito: revisão doutrinária e jurisprudencial à espécie .....................................................6 68

2.2. Tratamento normativo dado à espécie no Brasil \& sistema de análise de condutas da Lei n.

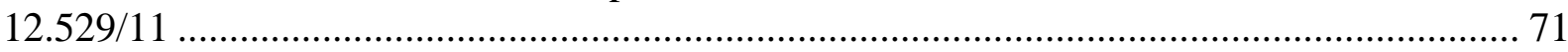

2.3. Tratamento jurisprudencial: a aplicação da regra per se na sistemática da regra da razão 74

2.4. Características: oportunidade e conveniência para cartelizar ............................................ 76

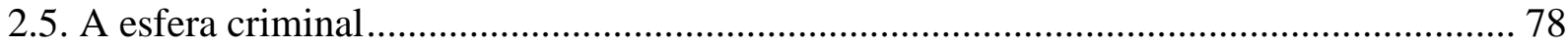

2.6. Paralelismo consciente: a não configuração da infração ………………………………..... 79

Capítulo II - Da incidência da jurisdição extraterritorial no Direito Antitruste................81

Seção I - Princípios de Direito Internacional necessários para a compreensão do instituto......81

1. Nota introdutória sobre a concepção de jurisdição extraterritorial.................................... 81

1.1. Fundamentos utilizados pelos Estados para justificar a extraterritorialidade de seu

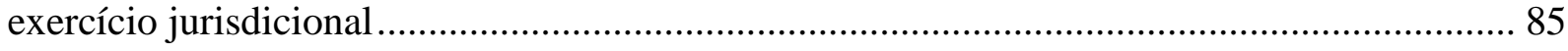

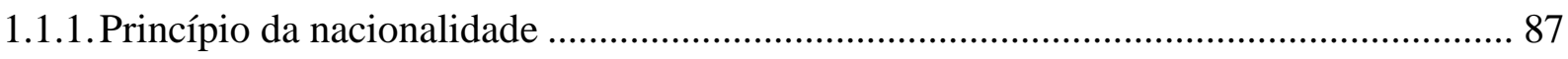

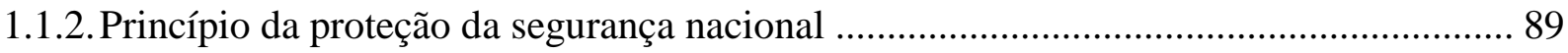

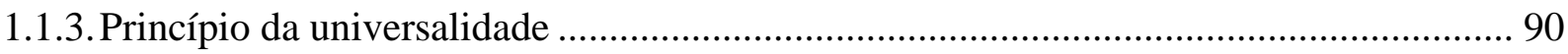




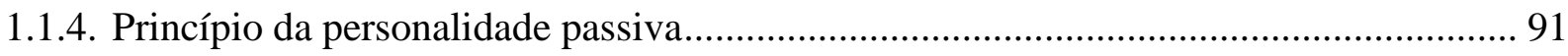

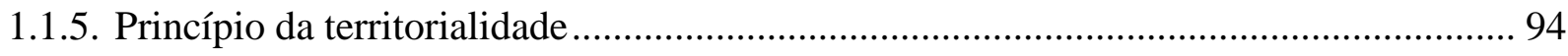

1.1.6. Princípio do efeito interno ou impacto territorial ou Teoria dos Efeitos ("Effects

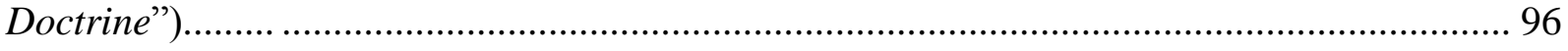

Seção II - A consagração do instituto pelo Direito Antitruste Brasileiro …………………..... 99

1. A jurisdição extraterritorial da Lei $\mathrm{n}^{\circ}$ 12.529/11 .............................................................. 99

2. Análise do artigo $2^{\circ}$ caput e $\S \S \&$ dos critérios de para aplicação extraterritorial da Lei Antitruste Brasileira ....................................................................................................... 100

2.1. Princípio da territorialidade e dos efeitos ...................................................................... 100

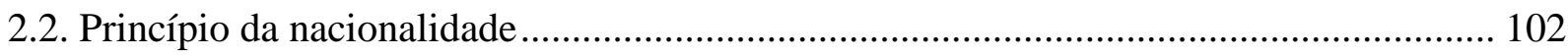

2.3. Análise da jurisdição pessoal ...................................................................................... 102

3. Sujeitos do Diploma Antitruste Brasileiro ..................................................................... 104

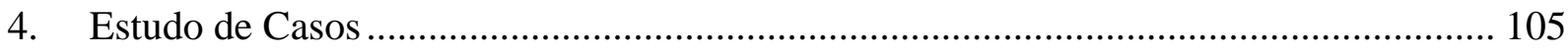

5. Extraterritorialidade da Defesa da Concorrência: análise de 42 jurisdições.................... 109

1. Panorama mundial no combate aos cartéis internacionais............................................. 112

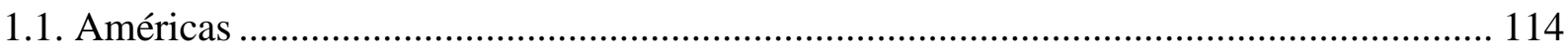

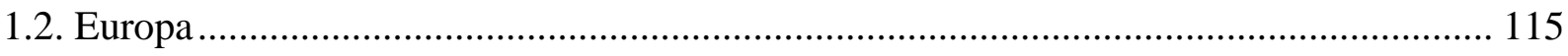

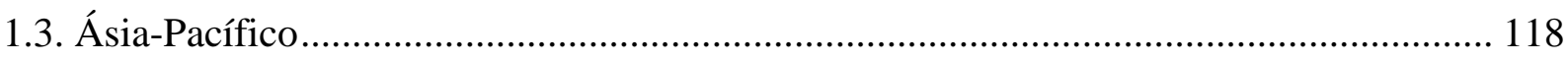

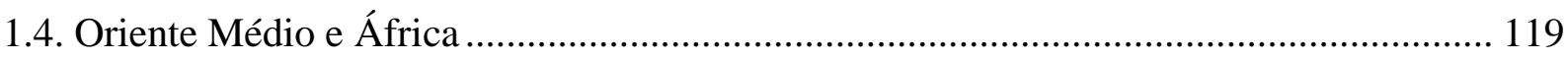


Capítulo III - A cooperação no combate aos cartéis internacionais: instrumentos existentes e características.........................................................................................121

Seção I - Cooperação multilateral e convergência: a soft law aplicada .............................. 121

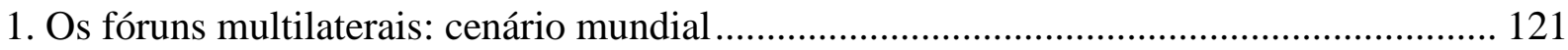

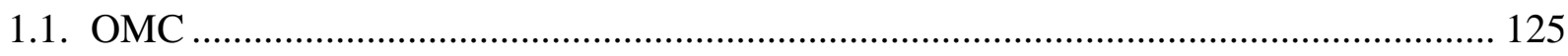

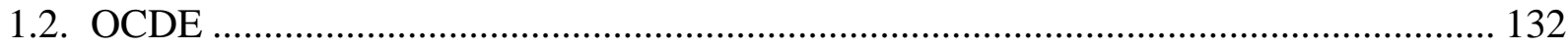

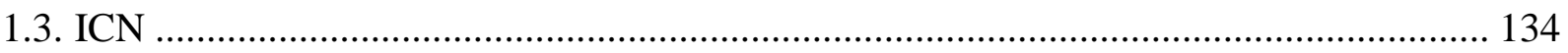

2. A ascensão dos fóruns multilaterais no Brasil ..................................................... 138

3. Principais obstáculos à cooperação internacional no âmbito da defesa da concorrência 141

Seção II - Cooperação bilateral: meios alternativos e eficazes da cooperação

Seção III - A cooperação internacional no Brasil em matéria antitruste no combate aos cartéis internacionais 153

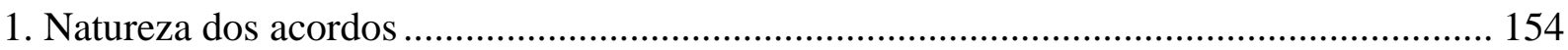

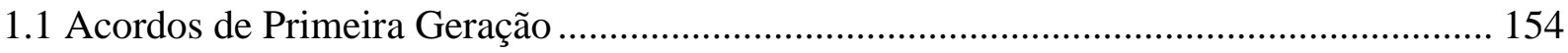

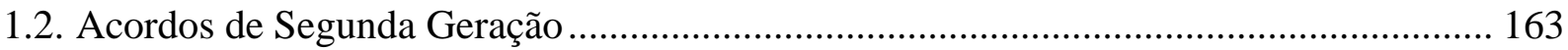

1.3. Acordos de Cooperação Judiciária e Assistência Mútua em Matéria Penal ................... 163

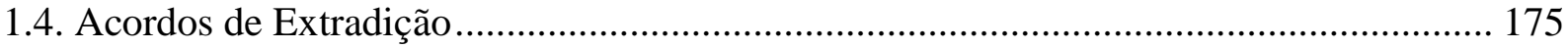

2.1 Acordos de Primeira Geração ......................................................................... 178

2.2. Acordos de Cooperação Judiciária e Assistência Mútua em Matéria Penal ................... 180

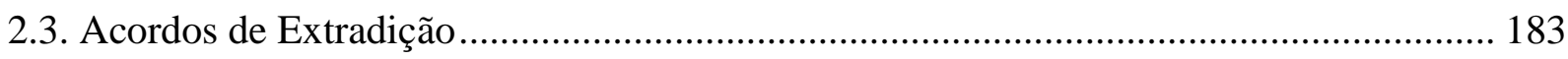

3. A jurisprudência brasileira em termos de cooperação ................................................ 184

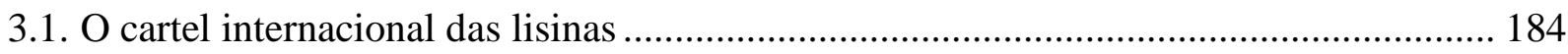




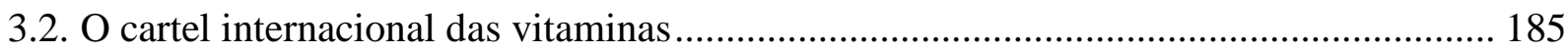

3.3. O suposto cartel entre 2001 e 2006 do LCD............................................................. 186

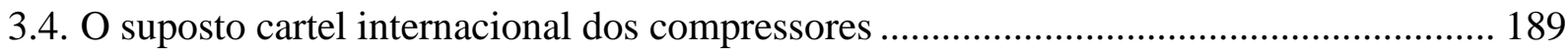

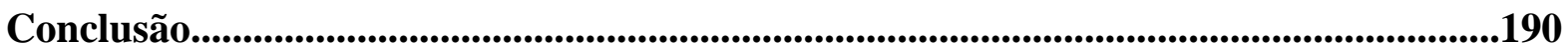

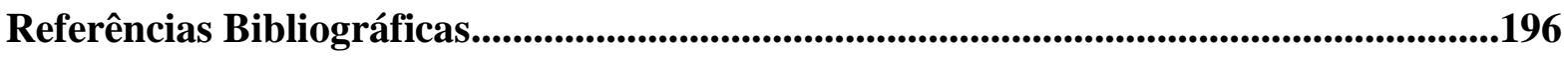




\section{Introdução}

O Direito Antitruste experimenta hoje uma verdadeira era dourada na qual a cooperação internacional entre os órgãos de defesa da concorrência e a aplicação de suas leis alcançaram níveis jamais vistos (SOKOL, 2007).

O fenômeno conhecido como "globalização" marcou as últimas décadas pela expansão da economia de mercado, pela liberalização do comércio mundial, pelos progressos tecnológicos - que não só são possíveis pela liberalização, mas que são, por si mesmos, molaspropulsoras da liberalização - e pela sem precedentes interdependência entre os países. Como resultado, os agentes econômicos passaram a expandir seus negócios globalmente. Essa mudança trouxe diversos aspectos positivos, entre eles, a promessa de um mundo mais rico, mais oportunidades de trabalho e, do ponto de vista do consumidor, ela aumentou significativamente suas opções de escolha. Efeito colateral dessa tendência é a internacionalização dos acordos entre concorrentes com vistas a limitar a concorrência. Os chamados cartéis, antes nacionais, passam a ter a dimensão dessa nova dinâmica da economia, a mundial. E, os danos ao mercado, antes limitados a um território, passam a poder atingir dezenas de jurisdições.

A emergência das multicorporações é assim acompanhada pelo risco de que tais empresas sejam tentadas a praticar atos contrários às leis de defesa da concorrência e que produzam efeitos em uma multiplicidade de jurisdições. Sem dúvida, o aumento no número de cartéis cujos efeitos tenham ocorrido em mais de uma jurisdição pode ser empiricamente comprovado. Estudo recente mostra que se, nos anos 90, o índice de descoberta dos cartéis internacionais variava de $4 \%$ a $6 \%$ ao ano, de 2003 a 2005, o índice passou para 35\% (CONNOR; HELMERS, 2007).

Um outro estudo (OCDE, 2002) estimou que o montante de comércio afetado por 16 cartéis de âmbito internacional excedeu os US\$ 55 bilhões no ano de 2001. Outro estudo 
(LEVENSTEIN; SUSLOW; OSWALD, 2003) mostrou que o valor das importações feitas por países subdesenvolvidos de produtos potencialmente afetados por cartéis em 1997 chegou à casa dos US\$ 51,1 bilhões, cifra quase $30 \%$ maior do que o total de ajuda oficial a todos os países subdesenvolvidos no mesmo ano.

Por outro lado, uma recente análise ${ }^{2}$ sobre a ótima política de repressão a cartéis internacionais mostrou que as punições não são suficientes para desestimular essa prática. Uma amostra de 283 cartéis internacionais descobertos desde janeiro de 1990 foi a base do estudo empírico referente aos cartéis globais. Foram ainda considerados os cartéis que operavam dentro dos EUA, dentro da União Europeia, além dos cartéis transnacionais atuando em dois ou mais continentes. Considerando apenas as penalidades pecuniárias, o estudo conclui que mesmo sob os pressupostos mais otimistas no que se refere à capacidade de se detectar os cartéis. Apesar do aumento das penas pecuniárias e da ampliação dos instrumentos de descoberta de cartéis em países como os EUA e os da UE, dentre outros, o valor dos lucros auferidos indevidamente com o cartel supera o valor das multas das condenações e dos montantes impostos por acordos. Tal resultado é reforçado quando se trata de cartéis globais que incluem países fora dos EUA e da UE e, onde a política de combate a cartéis ainda é mais frágil.

Os resultados obtidos por Connor, como ele mesmo comenta, reforçam trabalho anterior desenvolvido por Evenett (2004) que mostrou que cartéis internacionais eram capazes de discriminar países com e sem política de combate. Isto é, eram mais ativos nos países de pouca tradição na política antitruste, causando-lhes prejuízo maior do que nos países onde a probabilidade de serem descobertos, assim como as penalidades, eram maiores.

\footnotetext{
${ }^{2}$ Private International Cartels: Welfare Impacts and the Antitrust Response, apresentação do professor John Connor sobre cartéis no ICDC em 2003.
} 
Se, de um lado, os cartéis internacionais trazem colossais prejuízos ao ambiente concorrencial internacional, de outro, os resultados empíricos demonstram o paradoxo que as autoridades competentes de defesa da concorrência enfrentam: ainda que a persecução desses cartéis tenha recentemente incrementado o valor das penas pecuniárias, o conspirador médio tem incentivos monetários para participar de um esquema típico de fixação de preços em nível global.

As iniciativas de combate aos cartéis internacionais por parte das políticas de defesa da concorrência dos países têm sido suficientes para reprimir sua atuação? Como aperfeiçoar a repressão aos cartéis internacionais? Tais perguntas têm pertinência, entre outras, devido ao fato de que, muitas vezes, mesmo após o cartel ter sido pego e desmantelado pelas autoridades competentes desses países, a cartelização se perpetua nos países com autoridades de defesa da concorrência mais frágeis.

Assim, não é exagero afirmar que a falta de fiscalização e de perseguição eficaz. dos cartéis internacionais por parte das agências de defesa da concorrência pode comprometer todos os benefícios advindos da abertura dos mercados.

Da mesma forma, emerge desse contexto a complexa questão do conflito de jurisdições e de leis que podem se agravar a ponto de acarretar o desentendimento político entre os Estados envolvidos, prejudicando, assim, a harmonia das relações na esfera internacional. A aplicação extraterritorial de leis nacionais impõe problemas relevantes não só no âmbito do Direito, mas também no da esfera privada dos negócios internacionais. A título de ilustração, merecem registro as crescentes dificuldades enfrentadas pelas empresas internacionais para cumprir regimes de controle de concentração econômicas previstos em cerca de 70 das mais de 80 jurisdições estrangeiras que contam com uma legislação antitruste (U.S. DEPARTMENT OF JUSTICE, 2000, p. 87).

Se por um lado, as legislações antitrustes têm um viés nitidamente protecionista, preocupando-se apenas em preservar a concorrência em seus mercados (MARTINEZ, 2005), por outro, os países vêm se deparando cada vez mais com a situação de terem que exercer seus 
poderes de investigação e produzir provas fora de suas fronteiras e dar eficácia às penalidades impostas a indivíduos ou empresas estrangeiras.

É certo também que com o insucesso de Conferência Ministerial de Cancun (WTO MINISTERIAL CONFERENCE, 2003), realizada em 2003, e, na sequência, de Hong Kong (WTO MINISTERIAL CONFERENCE, 2005), em 2005, das negociações da OMC, a criação de um sistema supranacional de defesa da concorrência - originariamente proposto no Capítulo V da Carta de Havana (UNITED NATIONS CONFERENCE ON TRADE AND EMPLOYMENT, 1948) - deixou de ser uma realidade. Houve também outras tentativas de se criar um sistema internacional de regras de concorrência, como por exemplo, o International Antitrust Code, mas sem muito sucesso (PETERSMANN, 1999, p. 48-53). Ficou, assim, incerta e remota a possibilidade de se estabelecer regras internacionais sobre política de defesa da concorrência para uma maior convergência e harmonização entre os diferentes sistemas antitruste existentes em cada país.

É nesse contexto que a cooperação internacional entre as autoridades de defesa da concorrência surge enquanto instrumental de fundamental importância na persecução e no combate aos cartéis internacionais, considerados enquanto a mais danosa infração à ordem econômica.

Ora, a divergência de conteúdo nas regras materiais e nas posturas institucionais das diversas agências traz significativas dificuldades para a comunidade empresarial internacional. Tais empresas buscam maior transparência no procedimento das agências, mais rapidez e certamente padrões de regulamentações bem mais consistentes entre elas, já que podem enfrentar análises de suas operações e investigações concorrenciais em diversas jurisdições.

A cooperação entre as diversas agências antitruste para o combate dos cartéis internacionais tem sido enormemente exaltada pela OCDE em suas sucessivas recomendações de melhores práticas, pela ICPAC (2005), pela ICN (2007), pelo U. S. Department of Justice (2000) e pela Comissão Europeia, pelo Brasil, entre outros. Pode-se dizer que há um consenso 
generalizado de que no atual contexto econômico mundial nenhum aspecto da aplicação das leis de defesa da concorrência é mais importante do que a sua dimensão internacional (KLEIN, 1997). Por exemplo, os Guias de Melhores Práticas regularmente emitidos pela OCDE têm tido papel fundamental no desenvolvimento da cooperação entre as agências antitruste e têm inspirado diversos modelos de acordos entre as jurisdições. Em 2005, a OCDE adotou o documento de melhores práticas para a troca formal de informações entre autoridades em investigação de concorrência de hard core cartels (OCDE, 2005) que estabelece essa troca como elemento fundamental na cooperação, devendo ela ser baseada em alguns importantes princípios.

A despeito da grande propaganda que se faz à cooperação, é preciso reconhecer talvez o mais significativo obstáculo no combate aos cartéis internacionais no contexto da internacionalização da cooperação entre as agências antitruste. Notoriamente, dos Estados com forte tradição antitruste àqueles com pouca ou nenhuma tradição, certos governos acabam por encorajar medidas que prejudicam a livre concorrência internacional. São as chamadas “isenções antitruste para cartéis de exportação"

Como efeito da globalização econômica, emerge a necessidade da busca do melhor desenho cooperacional entre as Estados no combate às condutas anticompetitivas internacionais, sobretudo, aos cartéis. Independentemente do modelo escolhido pelos Estados, a intensificação da cooperação na luta contra os cartéis internacionais não pode e não deve atropelar as garantias individuais dos investigados.

\footnotetext{
3 Trabalho nacional bastante relevante sobre esses tipos de medidas adotadas por determinados países como forma de corrigir distorções no saldo comercial de um determinado setor ou alegadamente incrementar sua competitividade internacional é o de Martinez (2010). Para referência estrangeira, recomenda-se o trabalho de Evenett, Levenstein e Suslow (2004), The Changing International Status of Export Cartel Exemptions, em que as autoras fazem um trabalho empírico para diagnosticar que, dentre os 56 países pesquisados, dezessete adotavam explicitamente em suas leis tal tipo de isenção, enquanto outros adotam uma linguagem legislativa que se refere somente a condutas com efeitos no território nacional, não abarcando condutas que possam afetar outros territórios.
} 
Na última década, o Brasil tem se tornado referência para os países da América Latina no combate aos cartéis. No relatório da Organização para a Cooperação e Desenvolvimento Econômico (OCDE), divulgado em maio de 2010, o Brasil apontado como o líder no combate aos cartéis dentre os países latino-americanos (OCDE, 2010, p. 81). Tal referência decorre do louvável esforço das autoridades antitruste brasileiras em identificar e impor severas sanções pelas práticas de cartel, tal qual vem sendo feito pelas principais autoridades antitruste mundiais. A despeito desse reconhecimento internacional, a defesa da concorrência brasileira precisa amadurecer um dos seus mais importantes instrumentos de combate aos cartéis internacionais, a cooperação interjurisdicional.

Assim, é certo dizer que os mecanismos de cooperação são instrumentos fundamentais para melhorar a eficácia da política de defesa da concorrência, reduzir custos e diminuir os conflitos jurisdicionais entre Estados. Resulta daí o principal ponto a legitimar a análise acadêmica do instituto em questão: a premente necessidade do aprimoramento da técnica cooperacional do Brasil no combate aos cartéis internacionais.

A partir deste intróito, a presente dissertação tem por desafio tratar dos principais temas que permeiam a discussão da cooperação internacional entre as agências de defesa da concorrência, passando pelo estudo dos conceitos de cooperação jurídica internacional, princípios do Direito Internacional público que regem a competência internacional dos Estados, incluindo a delimitação do escopo da cooperação em sede da aplicação extraterritorial do Direito Antitruste, noções de Direito Concorrencial, os instrumentos e mecanismos de cooperação internacional existentes, as melhores práticas, entre outros.

O primeiro Capítulo da dissertação é o mais teórico, pois versa sobre o estudo dos conceitos essenciais que circundam a cooperação jurídica internacional; sua natureza jurídica; fontes e classificação. Também apresenta apontamentos sobre as principais noções de direito concorrencial e introduz os aspectos fundamentais conceituais, doutrinários e jurisprudenciais da infração ao Diploma Brasileiro Antitruste ora estudada, os cartéis. O Capitulo II também acrescenta alguns elementos esclarecedores para a melhor compreensão da reflexão que se 
propõe no último Capítulo. Apresenta princípios do direito internacional público que regem a competência internacional dos Estados, incluindo a delimitação do escopo da cooperação em sede da aplicação extraterritorial do direito antitruste, e, assim, pretende delimitar as concepções dos termos que permeiam a problemática da incidência da jurisdição extraterritorial em matéria antitruste. Neste sentido, os Capítulos I e II orientam a análise que seguirá no Capítulo III.

O Capítulo III tem por objetivo oferecer ao leitor um quadro compreensivo da evolução da atuação das autoridades antitruste brasileiras na cooperação internacional de combate aos cartéis transnacionais, em termos normativos e na utilização na prática, considerando, sobretudo, o contexto do recente recrudescimento do instrumental persecutório das autoridades nacionais de defesa da concorrência no combate às práticas anticompetitivas. Da mesma forma, por meio de uma análise comparativa entre os acordos internacionais de cooperação mais sofisticados e os instrumentos cooperacionais existentes no Brasil, à luz da sua florescente experiência, quer-se identificar os elementos necessários para o aprofundamento da técnica cooperativa brasileira de combate aos cartéis transnacionais.

Por fim, cumpre apontar sobre a metodologia e técnica de pesquisa empregues, que se pretende utilizar o método dialético para a busca da conclusão esperada, permeando esta técnica com (i) aspectos característicos do método histórico para alcançar um maior entendimento da questão através da evolução dos principais institutos investigados até os dias atuais e (ii) com aspectos do método dedutivo através do estudo de casos. Também, o trabalho terá como base fundamental de desenvolvimento a investigação dos arcabouços jurídicos sobre a matéria, com base no método comparatístico, tendo em vista a rica experiência do direito estadunidense e do europeu. Entende-se que o emprego de tais métodos viabilizará a busca da conclusão pretendida, qual seja, o desenho do melhor modelo cooperacional para o Brasil no combate aos cartéis. Não será descartada, também, a interdisciplinaridade com outros ramos do estudo jurídico que guardem relação com a matéria. 


\title{
Capítulo I - Apontamentos conceituais e teóricos
}

\author{
Seção I - Referencial teórico: cooperação internacional latu sensu
}

\section{Breve introdução ao tema: cooperação \& o contexto internacional}

A análise da cooperação jurídica internacional está imbricada àquela das relações internacionais que não é senão o estudo do sistema moderno de Estados, sendo fundamental, para tanto, o reconhecimento de que os principais atores do cenário internacional continuam sendo os Estados Nação, e não quaisquer outras pessoas de Direito Internacional.

Este campo específico de investigação pode ser caracterizado por meio das matérias que the deram origem, alcançando destaque a Filosofia Política e o Direito Internacional. Estes ramos da ciência interagem constantemente através da diplomacia, da guerra e das organizações internacionais, e, como requer o estudo conjunto e complementar com as demais áreas do Direito Público.

De tal maneira, o estudo de como os Estados se relacionam, ora se aproximando ora se afastando, apresenta-se essencial nos dias de hoje em razão da intensificação das relações entre os diversos Estados Nação, através da formação das organizações internacionais de integração, o avanço da globalização e a ampliação das trocas comerciais.

\section{Surgimento do instituto e o conceito adotado por este trabalho}


Segundo Soares (1994), a expressão cooperação internacional é definida pelo Dictionnaire de la terminologie du droit international como a "ação coordenada de dois ou mais Estados, com vistas a atingir resultados por eles julgados desejáveis”.

Para se compreender o instituto da cooperação internacional, faz-se necessário entender o seu surgimento, que se deu no pós-Segunda Guerra Mundial, quando os países tomaram consciência da necessidade de uma mútua cooperação para que resultados comuns fossem alcançados. Vários países do continente europeu foram fortemente afetados pela Grande Guerra, o que gerou um colapso estrutural generalizado no mundo. Em meio a esse cenário, para uma adequada reconstrução socioeconômica, parte da Europa passou a necessitar de ajuda de outros países, o que foi efetivado pela Organizações das Nações Unidas (ONU), instituição recém criada mas que foi de grande valia para o início das atividades de cooperação internacional.

Logo, pode-se afirmar que a ONU foi o marco jurídico da cooperação institucional, que permitiu, a um só tempo, que a idéia de cooperação fosse difundida, e que as atividades até então meramente idealizadas fossem concretizadas por meio de normas entre os entes de Direito Público Internacional. Tal iniciativa fomentou o estabelecimento de princípios e regras para reger essa cooperação entre Estados, preservando as peculiaridades e autonomia de cada um deles.

É de se notar, ainda, que a Carta das Nações Unidas, ao ser elaborada, refletiu os ideais dos Estados que demonstravam a necessidade de que fosse instituído um mecanismo internacional capaz de promover o progresso econômico e social, sanando problemas internacionais de caráter econômico, social, cultural e humanitário, promovendo a igualdade entre os povos.

Ainda segundo Soares (1994), é exatamente na Carta da ONU que se encontram os princípios da cooperação internacional, inseridos nos artigo 55 do Capítulo IX, que assim dispõe: 
Com o fim de criar condições de estabilidade e bem-estar, necessárias às relações pacíficas e amistosas entre as Nações, baseadas no respeito ao princípio de igualdade e direitos e da autodeterminação dos povos, as Nações Unidas favorecerão:

a) níveis mais altos de vida, trabalho efetivo e condições de progresso e desenvolvimento econômico e social;

b) a solução dos problemas internacionais econômicos, sociais, sanitários e conexos; a cooperação internacional, de caráter cultural e educacional; e

c) o respeito universal e efetivo dos direitos humanos e das liberdades fundamentais para todos, sem distinção de raça, sexo, língua ou religião (ONU, 1945).

$\mathrm{O}$ art. 56 do mesmo documento também apresenta princípios, a saber, "para a realização dos propósitos enumerados no artigo 55, todos os Membros da Organização se comprometem a agir em cooperação com esta, em conjunto ou separadamente".

Da análise dos dispositivos acima, percebe-se que a cooperação internacional, em sua origem, se preocupou com a promoção do desenvolvimento dos Estados, que devem ver representados os seus anseios e projetos. Ou, em outras palavras, a preocupação com o desenvolvimento de cada ente de Direito Público Internacional.

Embora Araújo (2008, p. 40) defina a cooperação jurídica internacional como o intercâmbio internacional para o cumprimento extraterritorial das medidas processuais do Poder Judiciário dum outro Estado, este trata-se de conceito bastante restritivo uma vez que desconsidera a cooperação entre autoridades administrativas - como o são algumas das agências estrangeiras de defesa da concorrência com as quais as autoridades brasileiras se relacionam - que igualmente se qualificam enquanto jurídicas.

Há, sim, clara preferência pela expressão "cooperação jurídica internacional” que decorre da idéia de que a efetividade da jurisdição, nacional ou estrangeira, pode depender do intercâmbio não apenas entre órgãos judiciais, mas também entre órgãos administrativos e/ou investigatórios, ou, ainda, entre órgãos judiciais e administrativos, de Estados distintos. Essa expressão foi utilizada pela Comissão do Ministério da Justiça, presidida por Cláudia Chagas, 
na elaboração do anteprojeto da denominada Lei de Cooperação Jurídica Internacional (SILVA, 2005).

\section{Delimitação da natureza jurídica do instituto}

Analisar a natureza jurídica de um instituto nunca é tarefa simples, pois clama do estudioso atenção redobrada, principalmente quando se trata de um instituto de tamanha complexidade, como a cooperação jurídica internacional, que pode ser enfrentada de diversos prismas.

Segundo Diniz (2010, p. 312), natureza jurídica é a "afinidade que um instituto jurídico tem, em diversos pontos, com uma grande categoria jurídica, podendo nela ser incluído a título de classificação". Para Magalhães (2007, p. 129), "quando se pesquisa a natureza jurídica de um instituto, o que se pretende é fixar em que categoria jurídica o mesmo se integra, ou seja, de que gênero aquele instituto é espécie”.

Tais conceitos fazem compreender que a natureza jurídica de um instituto consiste em identificar a sua própria essência, para então classificá-lo dentre as figuras existentes, ou seja, é a forma de localizá-lo topograficamente, buscando o seu gênero e a qual espécie se integra. Isso é o que se passa a fazer neste ponto da dissertação acerca do instituto da cooperação jurídica.

Conforme se viu acima, há uma tendência em se conceber a cooperação internacional como uma "ajuda", um auxílio aos países menos desenvolvidos e, consequentemente, mais carentes. Logo, pode-se afirmar que a cooperação jurídica internacional pode ser compreendida enquanto um valor de solidariedade, encontrando seus fundamentos na própria história da humanidade, em que aqueles que detêm maior poder, seja ele econômico ou cultural, auxiliam os entes menos privilegiados. 
Neste sentido, a cooperação internacional constitui expressão do valor da solidariedade, que é fundamento dos direitos e que significa uma relação entre pessoas que participam com o mesmo interesse na busca de certo bem e que se manifesta na atitude de uma pessoa com respeito a outras quando aquela coloca esforço num determinado tema pertinente a estas (CORTINA, 1990, p. 288).

Segundo Martinez (1999), a solidariedade pode ser compreendida como um valor que norteia a sociedade, uma vez reconhecidas as necessidades próprias e do outro, bem como os problemas, comuns ou não, na busca de uma solução advinda da atuação do Estado. Assim, defende o autor que o uso adequado da solidariedade enquanto valor conduziria os indivíduos a comportamentos positivos perante a sociedade e ao Estado, removendo obstáculos e promovendo a busca pela igualdade e pela liberdade dos indivíduos.

Nesse cenário, haveria intrínseca relação entre o instituto da cooperação institucional e a solidariedade, principalmente no que toca à adoção de um comportamento positivo perante a sociedade e o Estado, sem prejuízo da remoção dos obstáculos capazes de impedir o desenvolvimento e a superação dos problemas.

Neste ponto é importante ressaltar que a Constituição da República de 1988 traz expresso em seu texto a solidariedade, enquanto valor a nortear principalmente as políticas sociais, uma vez que encontra-se inserida no rol dos objetivos fundamentais do Estado, norteando as políticas voltadas à cooperação para o progresso da humanidade, além de reger as relações internacionais.

Apesar da correlação entre o instituto da cooperação internacional e o princípio da solidariedade, não é pacífico o entendimento de ser esta a natureza jurídica do instituto, tanto que Cervini (2000), ao enfrentar a problemática da natureza jurídica da cooperação internacional, apresenta teorias diversas.

Inicialmente, Cervini aponta que a cooperação internacional deve ser compreendida como uma jurisdição própria, ou seja, sem qualquer vinculação aos 
ordenamentos jurídicos dos Estados. Logo, esta seria a natureza jurídica da cooperação internacional. Mais adiante, apresenta uma segunda teoria para explicar a natureza jurídica da cooperação internacional, que seria a delegação de jurisdição, uma vez que há clara delegação de poderes para que outro Estado, ou organização, atue de acordo com os seus interesses, e em prol de um ideal comum. A terceira teoria apresentada pelo autor é a que compreende a cooperação jurídica internacional enquanto interação processual e funcional, que se assenta nas normas de Direito Internacional, e concebe os Estados como entes autônomos, mas que integram uma ordem jurídica internacional, sobre os quais incidem as normas dos tratados e convenções internacionais de que são signatários. Para esta teoria, e segundo explana Cervini, as normas de Direito Internacional atuam sobre os Estados de modo que a cooperação internacional se apresenta como um organismo de subsunção a esta ordem jurídica que, por sua vez, representa ideais comuns.

Essas breves considerações permitem compreender um pouco melhor o instituto da cooperação internacional, no tocante a sua natureza jurídica, como um misto dos ideais de solidariedade que norteiam os Estados, de forma expressa o Estado brasileiro, na busca de ideais comuns e no intuito de verem solucionados problemas específicos ou também comuns aos entes de Direito Público Internacional, sem ignorar a existência de um regime jurídico próprio a ser observado, composto por tratados e convenções internacionais, sem prejuízo da autonomia e soberania de que gozam os Estados.

\section{Classificação}

Uma análise sistematizada do tema cooperação internacional não pode prescindir de que seja apresentada uma classificação do instituto, adotando-se, no presente trabalho, os critérios da iniciativa da solicitação, da qualidade do ente que coopera, da finalidade e 
procedimento da cooperação jurídica internacional, e do procedimento utilizado para a efetivação da cooperação internacional.

Quanto à iniciativa na solicitação, primeiro critério a ser analisado, a cooperação internacional pode ser ativa ou passiva. Será ativa a cooperação quando se referir a quem solicita a assistência, e será passiva quando disser respeito àquele que é solicitado.

Machado (2005), ao enfrentar este critério de classificação, exemplifica que a cooperação jurídica internacional pode se dar de forma ativa, quando o Brasil remete uma carta rogatória a Estado estrangeiro para seu cumprimento; e será passiva, quando um Estado estrangeiro remete uma carta rogatória às autoridades brasileiras, para que o Superior Tribunal de Justiça conceda a exequatur. Percebe-se, portanto, que se trata de critério classificatório bem simples e limitado, sendo modalidade de cooperação internacional ativa sempre que o Brasil figurar como o Estado solicitante.

O segundo critério classificatório foca-se na qualidade daquele que coopera. Logo, em se tratando de autoridades judiciais, tem-se a denominada cooperação jurídica judicial; porém, se a autoridade cooperante for administrativa, estaremos diante da modalidade de cooperação jurídica administrativa.

Segundo Strenger (1981) a cooperação jurídica judicial se concretiza em três modalidades, sendo a primeira dela a atribuição ou distribuição da competência internacional entre as judicaturas dos distintos Estados. A segunda forma de exteriorização da cooperação jurídica judicial é o cumprimento extraterritorial de medidas processuais ditadas pela judicatura de um Estado, enquanto a terceira forma é o reconhecimento e a execução extraterritorial da sentença proferida pelos juízes de um Estado estrangeiro.

Quanto à finalidade da cooperação internacional, terceiro critério a ser enfrentado, faz-se necessária uma subdivisão, pois a cooperação pode se dar por mera assistência entre os Estados, como ocorre com a produção de provas, ou a mera notificação concretizada por um Estado estrangeiro. Pode, ainda, ter por finalidade causar gravames patrimoniais, como ocorre 
com o sequestro de bens, que pode ser cumprido em um território estrangeiro, desde que haja a intervenção do Estado. Ainda pode, a cooperação internacional, ter por escopo a execução de uma medida capaz de causar gravame irreparável aos direitos e liberdades do indivíduo, como ocorre com a extradição, compreendida como traslado forçado de pessoas (CERVINI, 2000).

Importante observar, neste ponto, que este critério de classificação é alvo de críticas, pois não há dúvidas que em determinadas situações há claro conflito de finalidade ou mesmo finalidades dúbias, pois um Estado pode solicitar medidas que, a um só tempo, podem envolver patrimônio, liberdade e meras notificações, sendo de pouca valia prática tal classificação.

Outro procedimento comumente utilizado como mecanismos de cooperação internacional é a homologação de sentença estrangeira, que objetiva reconhecer a eficácia de uma decisão proferida por outro Estado.

De igual forma, tem-se o procedimento de carta rogatória, que se destina ao cumprimento de medidas como a produção de provas, a comunicação de atos processuais, dentre outros, não se aplicando aos casos de extradição e de homologação de sentença estrangeira.

Por fim, no último critério de classificação encontra-se ainda o procedimento de pedido de auxílio direto, cujo objeto confunde-se com o objeto da carta rogatória, embora haja clara distinção quanto ao procedimento, já que este é mais ágil e menos burocrático, atingindo seus fins de forma mais eficaz.

\section{Fontes}


O enfrentamento das fontes do Direito tem importância crucial pelo seu caráter propedêutico e introdutório a todos os seus ramos, enfatizando o modo como o mesmo surge e se manifesta enquanto norma, e como se reflete nos indivíduos. Para Bobbio (1991, p. 197) “o conhecimento de um ordenamento jurídico (e também de um setor particular desse ordenamento) começa sempre pela enumeração de suas fontes”.

Logo, estudar as fontes é estudar a própria ciência jurídica e antes de qualquer coisa: o estudo das fontes permite desenvolver um rico percurso até a determinação do que são as regras jurídicas em si. Os itens a seguir se prestarão a apresentar as fontes formais ou de produção da cooperação jurídica internacional situada tanto no âmbito do Direito Internacional Público e Privado, como do Direito Interno, em nível constitucional e infraconstitucional.

No Direito Internacional Público, as fontes formais são os costumes e os tratados internacionais. No Direito Internacional Privado, as fontes formais são os acordos firmados entre os Estados, bilaterais, regionais ou multilaterais.

No Direito Interno, as fontes formais são a Constituição Federal e a legislação infraconstitucional vigente, como o Código de Processo Penal e a Lei de Introdução ao Código Civil no caso do Brasil.

\subsection{Direito Internacional}

Conforme se viu anteriormente, a natureza jurídica do instituto da cooperação internacional está intrinsecamente relacionada ao princípio da solidariedade, o que faz compreender a sua relação com a reciprocidade entre os Estados, ou seja, uma espécie de cortesia que um Estado faz para com o outro, seja por meio de uma acordo formal, como ocorre com os tratados e convenções internacionais, ou resultado de um costume no âmbito internacional. 
Dentre as fontes de Direito Internacional, no que se refere ao instituto da cooperação jurídica, tem-se a Convenção de Viena, datada de 1969, responsável por disciplinar o direito dos tratados. Tal convenção define o tratado como "um acordo internacional concluído entre Estados em forma escrita e regulado pelo Direito Internacional, consubstanciado em um único instrumento ou em dois ou mais instrumentos conexos qualquer que seja a designação específica”.

Os tratados internacionais surgiram da necessidade de se harmonizar as normas relativas à convivência e cooperação entre as nações, já que na atualidade, em especial por força da globalização, todas as relações, sejam econômicas, políticas ou culturais se dão em um espaço de tempo recorde, sendo imprescindível a regularização das condutas internacionais.

Em outras palavras, pode-se afirmar que a internacionalização é uma marca dos tempos modernos, fato ao qual não foi alheio o legislador constituinte ao promulgar a Constituição de 1988, pois consagrou, no art. $4^{\circ}$ do texto constitucional, uma série de princípios que regem as relações internacionais, assegurando a independência nacional, a prevalência dos direitos humanos, a autodeterminação dos povos, a não intervenção, a igualdade entre os Estados, a defesa da paz, a solução pacífica dos conflitos, a cooperação entre os povos para o progresso da humanidade e a concessão de asilo político como preceitos indispensáveis à integração econômica, política, social e cultural dos povos.

Percebe-se, portanto, que o fenômeno da globalização e da internacionalização não se limitam à esfera das relações econômicas, e influencia diretamente o Direito, pois a tomada de decisões pela comunidade internacional pode definir o destino dos ordenamentos jurídicos internos dos Estados.

Por isso Bonavides (2010, p. 123) assevera que a internacionalização contribuiu para a relativização do conceito de soberania e acrescenta: 
A crise contemporânea desse conceito envolve aspectos fundamentais: de uma parte, a dificuldade de conciliar a noção de soberania do Estado com a ordem internacional, de modo que a ênfase na soberania implicaria sacrifício maior ou menor do ordenamento internacional e, vice-versa, a ênfase neste se faz com restrições de grau variável aos limites da soberania, há algum tempo tomada ainda em termos absolutos; doutra parte, a crise se manifesta sob o aspecto e a evidência de correntes doutrinárias ou fatos que ameaçadoramente patenteiam a existência de grupos ou instituições sociais concorrentes, as quais disputam ao Estado sua qualificação de ordenamento político supremo, enfraquecendo e desvalorizando por consequência a ideia mesma de Estado.

Neste cenário, para que haja maior harmonia entre as nações, faz-se necessário o estabelecimento de normas que garantam, na esfera internacional, a proteção não apenas aos Estados soberanos, mas também aos seus integrantes. Os tratados internacionais são imprescindíveis nesse contexto, pois se propõem a estabelecer as relações entre as normas de Direito Internacional e as normas de cada Estado, resguardando, repita-se, a soberania das nações.

Ariosi (2004), ao enfrentar o tema, aponta que os tratados internacionais se apresentam como elemento decisivo na formação do sistema jurídico internacional que influencia a própria organização dos Estados, sendo uma importante fonte do Direito Internacional Público. A origem dos tratados, segundo a mesma autora, é tão antiga quanto a existência das sociedades organizadas, ainda que em sua forma primitiva, e visavam, não raras vezes, firmar alianças entre os povos, combater os inimigos comuns, estabelecer regras de comércio, migrações e extradições, dentre outras (ARIOSI, 2004).

Com a multiplicação dos regimes republicanos, e a constitucionalização das monarquias, que substituíram os regimes autoritários em grande parte do planeta, os tratados passaram a ser responsáveis pela exteriorização da interdependência crescente nas relações internacionais.

Todavia, foi com a Convenção sobre Tratados de Havana, datada de 1928, que os tratados evoluíram em seu aspecto normativo, ganhando importância entre os povos, tendo 
atingido o seu apogeu com a Convenção de Viena, em 1969, na qual foram estabelecidas normas relativas aos próprios tratados internacionais.

Coube, portanto, à Convenção de Viena estabelecer a definição do termo tratado, conceituando-o como o "acordo internacional celebrado por escrito entre Estados e regido pelo Direito Internacional, constante de um instrumento único ou de dois ou mais instrumentos conexos e qualquer que seja sua denominação particular”.

Fato é que o conceito de tratado pode assumir várias denominações, variando conforme seu conteúdo, objeto ou finalidade, embora se caracterize, em sua essência, por ser firmado entre atores internacionais, por meio da expressão da mútua vontade, de forma escrita (ARIOSI, 2004).

No tocante à classificação, que sofre variações conforme o critério utilizado pela autora, os tratados são classificados quanto ao número de partes envolvidas, ao procedimento empregado em sua elaboração, ou pela natureza as normas que apresenta.

Em relação ao número de partes envolvidas, podem os tratados serem classificados como bilaterais ou multilaterais, se estabelecidos entre dois Estados ou entre vários (ACCIOLY; SILVA; CASELLA, 2010).

Quanto ao procedimento empregado na elaboração, podem ser classificados em tratados em sentido estrito e em acordos simplificados, sendo que este último se apresenta sobre a modalidade de acordos executivos, que devido à abrangência dispensam a ratificação, operando efeitos imediatos, ou seja, não exigem que os Poderes Internos dos Estados manifestem sua intenção de aderir às normas neles constantes, ao contrário do que ocorre com os tratados em geral, que necessitam ser absorvidos pelo ordenamento interno, por meio da ratificação, para, só depois, surtir efeitos jurídicos (ACCIOLY; SILVA; CASELLA, 2010).

No tocante à natureza das normas, os tratados são classificados em contratuais, quando estabelecem operações jurídicas, e normativos, quando criam regras jurídicas válidas e 
objetivas, que têm por escopo reger os sujeitos de Direito Internacional que se encontrem em situação semelhante (ACCIOLY; SILVA; CASELLA, 2010).

Em relação aos elementos essenciais para a caracterização dos tratados, há quatro, quais sejam: o consentimento das partes, a habilitação dos agentes signatários, o mútuo consentimento, e o objeto lícito e possível.

Inicialmente somente os Estados possuíam capacidade para firmar tratados, o que cedeu com a evolução e progresso das relações jurídicas, sendo reconhecida a capacidade de outros personagens figurarem como partes nos tratados internacionais, como ocorre com as organizações internacionais, ou seja, na atualidade basta que a parte seja pessoa jurídica de direito internacional público para figurar como tal (MAZZUOLI, 2010).

Todavia, para que as partes possam expressar o livre consentimento, os seus representantes devem estar legalmente investidos de poderes para firmar o tratado em nome do Estado, pois tal compromisso é firmado perante a comunidade internacional. Ora, significa dizer, portanto, que as partes interessadas devem estar habilitadas perante os demais membros para aderirem às normas internacionais em nome de determinado Estado. Apenas para exemplificar, no ordenamento jurídico pátrio, por força do art. 84, XIII, da Constituição, o Presidente da República é competente para, na qualidade de Chefe de Estado, celebrar tratados e convenções internacionais, sendo lícito, contudo, que, na fase de negociações, entes públicos por ele habilitados o representem, desde que possua poderes plenos para tanto (MAZZUOLI, 2010).

O segundo elemento caracterizador do tratado é o livre consentimento, o que nada mais é que a livre manifestação da vontade dos sujeitos envolvidos (MAZZUOLI, 2010).

De tal regra decorre a especificidade dos vícios de consentimento nos atos de Direito Internacional, pois para a validade do tratado se faz mister a licitude de seu objeto, a possibilidade de sua consecução e, ainda, a manifestação de vontade dos Estados envolvidos. 
Além dos tratados internacionais, há o costume internacional, compreendido como prática geral que reflete uma obrigação jurídica, fruto da correspondência diplomática, das declarações de política externa e da prática de órgãos internacionais (BROWNLIE, 1997).

Em se tratando de Direito Internacional Público, podem-se citar, como principais fontes da cooperação jurídica, a Convenção Interamericana sobre Cartas Rogatórias, datada de 1975, o Protocolo Adicional, do ano de 1979, a Convenção das Nações Unidas contra o Crime Organizado Transnacional, editada no ano de 2000, a Convenção das Nações Unidas de Mérida, do ano de 2003, e o Tratado Interamericano, datado de 1947.

Já em se tratando de Direito Internacional Privado, podem ser citados o Código de Bustamante, do ano de 1928, e os acordos bilaterais firmados entre os Estados soberanos, que impõem direitos e deveres aos entes de direito público internacional.

No que se refere aos Direitos Humanos, e as normas de Direito Internacional, temse a Declaração Universal dos Direitos Humanos, datada de 1948, a Declaração Americana dos Direitos e Deveres do Homem, também do ano de 1948, o Pacto Internacional sobre Direitos Civis e Políticos, do ano de 1966, e a Convenção contra a Tortura e outros Tratamentos ou Penas Cruéis, Desumanos ou Degradantes, editada em 1984.

Por fim, não se pode esquecer, como importante fonte de Direito Internacional, o Pacto de São José da Costa Rica, que veio a lume no ano de 1984, como a Convenção Americana sobre Direitos Humanos.

Para o presente trabalho, como veremos no Capítulo III, será utilizada a definição de tratado em sentido lato, como qualquer acordo formal concluído entre sujeitos de Direito Internacional Público e destinado a produzir efeitos jurídicos (REZEK, 1994, p. 14) ${ }^{4}$. O 
acordo formal pode receber outras denominações como convênio, protocolo de intenções, memorando, pacto, dentre outras, de modo que todas estas citadas serão tratadas de forma sinônima.

Um esclarecimento final, a propósito, é necessário ser feito. Na noção de acordo formal está contido o significado daquilo que se denomina hard law e soft law ${ }^{5}$.

\subsection{Direito Brasileiro}

Inicialmente, para melhor compreensão das fontes do direito pátrio e sua relação com o instituto da cooperação internacional, é necessário compreender a hierarquia dos tratados internacionais no ordenamento jurídico, sendo mister, para tanto, dividi-los em dois grupos distintos: os tratados internacionais que versam sobre os direitos humanos e os tratados internacionais que tratam de temas diversos.

Anote-se que tal divisão é proposta pela própria Constituição, que confere natureza distinta aos tratados de direitos humanos, e, por conseguinte, coloca-os em posição hierárquica diferenciada.

Todavia, para compreensão de tal distinção, faz-se necessário observar que a hierarquia dos tratados está diretamente relacionada às teorias monistas e dualistas.

\footnotetext{
${ }^{5} \mathrm{O}$ termo soft law emergiu no contexto da prática reiterada e cada vez mais atuante no século XX da diplomacia multilateral e se refere a instrumentos "quase-legais", que não possuem caráter juridicamente vinculativo, sendo mais brandos do que as leis tradicionais, muitas vezes referidas como hard law ou jus cogens. A inadimplência da soft law se dá por um sistema de sanções distintas daquelas previstas nas normas tradicionais, possivelmente assimiláveis às obrigações morais versadas nos sistemas obrigacionais internos dos Estados. Cf. Soares (2004). Para uma análise importante sobre jus cogens, numa perspectiva brasileira, ver artigo de Rodas (1974, p. 125-36). Para uma literatura internacional sobre a distinção entre soft e hard law, ver Abbott e Snidal (2000).
} 
Os adeptos da teoria monista compreendem o sistema jurídico como único, embora tal corrente se divida em duas vertentes: a primeira defende a primazia do Direito Internacional sobre o direito interno de cada Estado, enquanto a segunda sustenta a soberania do direito interno de cada Estado em relação às normas de Direito Internacional, ou seja, o direito interno sempre se sobrepõe ao Direito Internacional (ACCIOLY; SILVA; CASELLA, 2010).

Os dualistas, por sua vez, veem dois sistemas independentes, ou seja, o direito interno de cada Estado soberano, assim como as normas de Direito Internacional, são independentes e autônomas, não sendo necessária consonância entre ambas. Logo, para que as normas de Direito Internacional tenham aplicação no direito interno, faz-se necessária a sua incorporação, por meio do processo de ratificação (ACCIOLY; SILVA; CASELLA, 2010).

Diante de tais correntes, sempre que existir um conflito entre o ordenamento jurídico interno e o Direito Internacional, a solução dependerá do sistema adotado, não havendo, por conseguinte, regra geral.

Logo, para os adeptos da teoria dualista, havendo conflito este deverá ser solucionado pelo princípio de que a lei posterior derroga a lei anterior, podendo o Estado ser inclusive responsabilizado na seara internacional caso descumpra uma norma de Direito Internacional. De outra forma, se o ordenamento interno adotar a teoria monista, em que as normas formariam um único sistema, tem-se que analisar o critério hierárquico, para então compreender qual regra prevalece no caso concreto.

Acontece que tais critérios, como critica a doutrina, podem não apresentar uma solução satisfatória ao conflito, principalmente quando se trata de tratados de direitos humanos, uma vez que a Constituição da República de 1988 conferiu hierarquia diferenciada a essa modalidade de tratados (ACCIOLY; SILVA; CASELLA, 2010). 
Neste ponto não se pretende enfrentar a hierarquia dos tratados de direitos humanos no Brasil, mas tão somente tecer comentários gerais que permitirão a compreensão do tema a ser abordado no próximo capítulo, visando responder ao problema de pesquisa.

Todavia, no que se refere aos tratados internacionais que versam sobre matéria diversa dos direitos humanos, importante observar como se posiciona a doutrina acerca do critério hierárquico para a solução de eventuais conflitos.

Inicialmente vale frisar que o ordenamento jurídico brasileiro adota a teoria monista, já que se fosse adotada a teoria dualista bastaria saber qual a norma foi editada posteriormente e, consequentemente, seria esta a aplicada. Porém, ao se adotar o critério hierárquico, divergências surgem.

A primeira corrente defende que os tratados internacionais que versem sobre matérias que não sejam direitos humanos encontram-se em paridade com o direito interno, revestindo-se do status de lei ordinária.

Uma segunda corrente, por sua vez, entende que os tratados possuem natureza infraconstitucional, mas supralegal, fundamentando tal posicionamento na análise do art. 102, III, "b" da Constituição da República de 1988, que confere ao Supremo Tribunal Federal, guardião da Constituição, a competência para declarar a inconstitucionalidade dos mesmos. Sobre a questão, assim se manifesta Gilmar Ferreira Mendes (1990, p. 266):

[...] a pronúncia de inconstitucionalidade, com o reconhecimento da nulidade, parece atingir, tão-somente, as normas nacionais de aprovação, ratificação e promulgação. No que concerne ao complexo normativo estabelecido pelo tratado ou convenção, há de se admitir que o juízo de inconstitucionalidade se resolve na não-aplicação, não se afigurando possível a decretação da nulidade, na espécie.

Importante observar que a declaração de inconstitucionalidade de um tratado internacional, pelo STF, não pode jamais implicar em sua nulidade, pois configuraria na 
ingerência do ordenamento interno de um país atingindo instrumentos integrantes de um sistema normativo diverso, no caso em tela de cunho internacional, sendo necessário tão somente afastar a sua aplicação internamente.

Logo, percebe-se que os tratados de Direito Internacional que versem sobre matéria diversa de direitos humanos, no ordenamento jurídico pátrio, se equiparam às leis ordinárias, estando sujeitos, inclusive, ao controle de constitucionalidade, sem que isso implique em sua nulidade, mas afasta a sua aplicação por incompatibilidade de suas normas com aquelas previstas na Constituição da República de 1988.

Diante de tais considerações, percebe-se que a cooperação internacional encontra suas fontes formais nos tratados ratificados pelo Brasil, sem prejuízo da legislação constitucional e infraconstitucional, dentre os quais se insere o Código de Processo Penal, a Lei de Introdução ao Código Civil, dentre outros.

Anote-se que não se pretende esgotar a matéria, mas apenas demonstrar como o Brasil disciplinou alguns procedimentos, como ocorreu, por exemplo, com os tratados firmados com diversos Estados estrangeiros, no qual o Brasil se comprometeu a extraditar os cidadãos estrangeiros que aqui se encontrem, sendo assegurada a reciprocidade, como é o caso da Argentina, de Portugal e da Espanha, dentre outros.

No que se refere a provas, o Brasil é signatário das Convenções da Organização dos Estados Americanos - OEA, sem prejuízo de outros tratados que foram introduzidos no ordenamento jurídico pátrio e que versam sobre a cooperação internacional, como ocorre com a Convenção das Nações Unidas contra o tráfico ilícito de entorpecentes e substâncias psicotrópicas, introduzida no ordenamento jurídico por meio do Decreto n. 154/1991, e a Convenção das Nações Unidas contra o crime organizado transnacional, por força do Decreto n. $5.015 / 2004$.

Como já apontado, o Brasil também ratificou o Código de Bustamante, que versa sobre os Direitos dos Tratados, e o fez por meio do Decreto n. 18.871/1929. 
Todos os instrumentos acima são multilaterais, ou seja, envolvem o Brasil e diversos Estados estrangeiros. Todavia, têm-se as fontes bilaterais de cooperação internacional, ou seja, documentos firmados entre o Brasil e determinado Estado, com objetos também específicos, como por exemplo o Decreto n. 3.810/2001, assinado pelo Brasil e os Estados Unidos da América.

Não se pode ignorar, ainda, que no próprio texto da Constituição da República de 1988, além de ter consagrado o princípio da solidariedade, o legislador constitucional introduziu uma série de dispositivos voltados a assegurar a cooperação jurídica internacional.

Cumpre salientar que no preâmbulo da Constituição, o Brasil reafirmou a sua forma de Estado, reconhecendo a autonomia e a soberania, e ressaltou a busca de soluções pacíficas das controvérsias, e a plena realização dos direitos sociais e individuais.

Ademais, em seu art. $3^{\circ}$, dentre os objetivos da República, o legislador expressamente assegurou a atenção ao valor da solidariedade, reconhecendo ser a cooperação entre os povos imprescindível ao progresso da humanidade, além de nortear as relações internacionais do Brasil.

Quanto aos procedimentos de cooperação internacional, o texto constitucional estabeleceu, em seu art. 102, I, “g”, a competência do Supremo Tribunal Federal para o julgamento da extradição solicitada por Estado estrangeiro, enquanto no art. 105, I, “i”, consagrou a competência do Superior Tribunal de Justiça para o conhecimento e execução das cartas rogatórias passivas, ou seja, aquelas encaminhadas pelo Estado estrangeiro, sem prejuízo da competência da Justiça Federal para sua execução (BRASIL, 1988, X, art. 109).

Além das normas constitucionais, tem-se o Decreto-lei n. 4.657/1942 - Lei de Introdução ao Código Civil, diploma legal que estabelece normas relacionadas à aplicação da lei estrangeira e que alcança o instituto da cooperação jurídica internacional, trazendo dispositivos específicos acerca de qual lei será aplicada em cada caso, além das limitações à prescrição de atos e sentenças proferidas por Estados estrangeiros. 
Ainda, tem-se a Lei n. 6.815/1980, denominada Estatuto do Estrangeiro, que, dentre outros procedimentos, disciplina a extradição.

O Código de Processo Civil também trouxe em seu bojo dispositivos acerca da admissibilidade e forma de cumprimento da carta rogatória, como ocorre com o art. 210, que remete à Convenção Internacional acerca do tema. E o mesmo ocorre com o Código de Processo Penal, que regulamenta as relações jurisdicionais com as autoridades estrangeiras, nos termos do art. 780 e seguintes, como ocorre com o art. 783, que disciplina as cartas rogatórias, sem, contudo, estipular qualquer regra acerca da legislação aplicável.

\section{Procedimentos da cooperação jurídica internacional para fins de produção de prova}

Alguns procedimentos de cooperação jurídica internacional já foram citados ao longo do presente estudo, tais como o procedimento de extradição, de cumprimento de carta rogatória, dentre outros, procedimentos que são diversos, principalmente no que se refere ao objeto e à finalidade a ser alcançada.

A carta rogatória é um instrumento jurídico destinado à prática de determinadas diligências, a serem cumpridas pela autoridade judiciária estrangeira, tal como a comunicação de atos processuais (citações e intimações), ou mesmo voltada à comunicação de atos que devam ser cumpridos ou realizados fora do território brasileiro, como avaliações, perícias, oitivas de testemunhas, dentre outros.

Logo, pode-se afirmar que a carta rogatória surge sempre que se faz necessário acionar a autoridade judiciária para que auxilie em determinada instrução processual (PEREIRA, 1984), e visa garantir não apenas a rapidez e eficácia dos atos processuais, mas também assegurar os direitos dos envolvidos na relação jurídica, observando as normas 
constitucionais e internacionais em vigor. Desta feita, o procedimento da carta rogatória visa a transmissão de pedidos judiciais, motivo pelo qual pode ser considerada um verdadeiro veículo de transmissão de qualquer pedido judicial. Todavia, não há um tratamento uniforme no âmbito do Direito Internacional e, no caso do Brasil, algumas regras disciplinam o tema, tais como os acordos bilaterais de cooperação entre o Brasil e os membros do Mercosul.

As cartas rogatórias podem ser classificadas de acordo com o objeto, quando serão denominadas de ordinatórias, instrutórias ou executórias. Por carta rogatória ordinária entende-se aquela cuja finalidade é a mera produção de atos como a intimação, citação ou notificação, ou seja, a prática de um ato processual. A carta instrutória, por sua vez, objetiva a coleta de provas, ao passo que a carta rogatória executória objetiva a prática de atos constritivos, como a apreensão de bens, o sequestro, dentre outras (BRAZ, 2004).

Quanto à iniciativa, as cartas rogatórias podem ser classificadas em ativa e passiva. São ativas as cartas rogatórias expedidas pelo Brasil, que devem ser encaminhadas por intermédio do Ministério das Relações Exteriores, ou do Ministério da Justiça, que não emitem qualquer juízo de valor sobre o pedido de cooperação, pois a eles cabe apenas verificar a observância das formalidades exigidas pelo acordo internacional, ou pela legislação do Estado estrangeiro que figura como requerido. Em se tratando de carta rogatória passiva, cuja execução se dá no Brasil, há de ser observada a formalidade de se passar pelo Superior Tribunal de Justiça, órgão do Judiciário responsável pela execução das cartas rogatórias passivas, desde o advento da Emenda Constitucional n. 45/2004. Anote-se que o procedimento a ser observado foi regulamentado pelo Superior Tribunal de Justiça por meio da Resolução n. 974, e se restringe àquelas cartas rogatórias que necessitem de juízo de deliberação, como ocorre com as hipóteses de cooperação administrativa, que são atendidas diretamente pelos juízes de primeira instância, sem a intervenção do Superior Tribunal de Justiça.

Além das cartas rogatórias, tem-se o procedimento denominado auxílio direto, compreendido como a cooperação que se realiza entre autoridades centrais dos Estados, desde 
que estes tenham disciplinados no seu ordenamento tal mecanismo de mútua assistência, por meio de acordos ou tratados bilaterais específicos.

Cumpre salientar que o auxílio direto não se particulariza apenas pela forma de processamento, já que é gerenciado pelas autoridades centrais, mas sim pelo fato de que o Estado estrangeiro não se apresenta na condição de juiz, mas sim de um administrador, uma vez que o pedido encaminhado não é de cunho judicial, mas sim uma mera solicitação a outra autoridade judicial do Estado, para que sejam tomadas providências (DIPP, 2008).

Percebe-se, portanto, que a distinção entre a carta rogatória e o pedido de auxílio direto é a não intervenção da autoridade judicial do Estado requerido, pois é a própria autoridade administrativa quem toma a decisão uma vez provocada pela autoridade estrangeira, desde que preenchidas as necessidades formais.

Importante observar que inexiste no Brasil pedido de auxílio direto no texto constitucional, mas sim vigência infraconstitucional, por meio da ratificação de tratados internacionais e acordos que preveem a cooperação em determinadas hipóteses.

\section{Direitos fundamentais: os limites da cooperação}

A cooperação entre o Sistema Brasileiro de Defesa da Concorrência (SBDC) e suas contrapartes estrangeiras deve encontrar seus limites no ordenamento jurídico brasileiro, sobretudo nas garantias processuais dos investigados. Em outras palavras, a persecução aos cartéis internacionais não pode ser um fim em si mesmo. Se, de um lado, há a urgência reconhecida pelos Estados da utilização de mecanismos tais como a cooperação entre as agências antitruste para a luta contra os cartéis transfronteiriços, de outro lado, há a consciência cada vez mais profunda de que os direitos fundamentais devem ser colocados enquanto termo de referência nessa matéria (GRINOVER, 2004). 
O Projeto de Resolução elaborado em 1992, durante a reunião preparatória de Helsinque para o XV Congresso da Associação Internacional de Direito Penal (AIDP) ${ }^{6}$ realizado no Rio de Janeiro, em setembro de 1994, confirmou dever ser dada proeminência à proteção dos direitos do homem diante das obrigações internacionais dos Estados de cooperarem em matéria penal (GRINOVER, 2004). O Projeto prevê a recusa da cooperação ou ainda sua submissão a certas condições para que não haja violações de direitos fundamentais ${ }^{7}$.

Neste sentido, percebe-se também uma grande afluência de convenções multilaterais, europeias ${ }^{8}$ e americanas ${ }^{9}$, dispondo sobre a necessidade de uma proteção mais forte aos direitos fundamentais do homem em um comprometimento internacional do sistema das liberdades públicas. É de se ressaltar que o Supremo Tribunal Federal (STF) não tem sido refratário a essa tendência mundial. Em decisões bastante competentes, o Pretório Excelso ${ }^{10}$ vem defendendo a necessidade do respeito pelo Poder Público às prerrogativas jurídicas que compõem a garantia constitucional do due process of law como expressiva limitação à

\footnotetext{
${ }^{6}$ A AIDP é órgão consultivo das Nações Unidas em matéria penal e congrega cerca de 3.000 membros em 50 países. O objetivo da associação é estabelecer a aproximação e a colaboração entre aqueles que, em diferentes países, se dediquem ao estudo do Direito Penal e da criminalidade, para promover o desenvolvimento teórico e prático de um Direito Penal Internacional (AIDP BRASIL, 2010).

${ }^{7}$ Nesse mesmo sentido, cf. art. $6^{\circ}$ do Decreto-Lei português n. 43/91 e art. $2^{\circ}$ da Lei da Confederação Helvética (1981).

${ }^{8}$ Citamos a Convenção Européia dos Direitos do Homem (1950), o Pacto Internacional sobre Direitos Civis e Políticos (1966) e a Carta dos Direitos Fundamentais da União Européia (1999), que constitui a mais moderna codificação dos direitos fundamentais do mundo.

${ }^{9}$ Citamos o Código Bustamante de Direito Internacional (1928), a Convenção Americana sobre os Direitos do Homem e a Convenção Interamericana sobre Direitos Humanos (Pacto de São José da Costa Rica, 1969).

${ }^{10} \mathrm{O}$ STF também ressaltou a garantia do princípio em questão mesmo em procedimentos de índole administrativa. "A jurisprudência do Supremo Tribunal Federal tem reafirmado a essencialidade do princípio que consagra o due process of law, nele reconhecendo uma insuprimível garantia, que instituída em favor de qualquer pessoa ou entidade, rege e condiciona o exercício, pelo Poder Público, de sua atividade, ainda que materialmente administrativa, sob pena de nulidade do próprio ato punitivo ou da medida restritiva de direitos. Precedentes. Doutrina". Cf. Mandado de Segurança n. 26.358-0, Distrito Federal.
} 
atividade persecutória do Estado ${ }^{11}$. É a qualificação do postulado do devido processo legal enquanto requisito legitimador da própria persecutio criminis.

Entende-se, assim, que qualquer meio de cooperação internacional que seja utilizado pelo Brasil em determinada investigação criminal deve desenvolver-se na plenitude do due process of $l a w^{12}$, princípio estabelecido no artigo $5^{\circ}$ inciso LIV $^{13}$ na Constituição Federal de 1998 indispensável à manutenção e efetivação do Estado Democrático (MAIA NETO, 2003). Tal princípio impede toda restrição ilegítima aos direitos dos homens sem um processo previamente estabelecido e com possibilidade de ampla participação contemplando também elementos tais como, oferecer decisões motivadas, o contraditório, a ampla defesa incluindo a defesa técnica, exclusão das provas obtidas por meios ilícitos, a transparência e a publicidade da atividade estatal. Mais do que isso, o confronto entre o poder punitivo do Estado e o direito de liberdade do cidadão, observa Ada Pellegrini Grinover, deve ser feito em termos de equilíbrio, assegurada a efetiva paridade de armas (GRINOVER, 1992, p. 43).

Efetivar o devido processo legal significa respeitar e fazer respeitar ${ }^{14}$ as garantias fundamentais do cidadão previstas na Constituição também nas relações em que o Brasil estabelecer com outros países, sendo certo, assim, que a essencialidade da cooperação

\footnotetext{
${ }^{11}$ Nesse sentido, cf. Extradições n. 633-9 e n. 977, HC 94601 CE - CEARÁ, AP 470 AgR, HC 94016, RE 158215 RS - RIO GRANDE DO SUL.

${ }^{12}$ Sobre o due process of law, vale trazer o voto do Ministro Carlos Velloso "abrindo o debate, deixo expresso que a Constituição de 1988 consagra o devido processo legal nos seus dois aspectos, substantivo e processual, nos incisos LIV e LV, do art. $5^{\circ}$, respectivamente. (...) Due process of law, com conteúdo substantivo substantive due process - constitui limite ao Legislativo, no sentido de que as leis devem ser elaboradas com justiça, devem ser dotadas de razoabilidade (reasonableness) e de racionalidade (rationality), devem guardar, segundo W. Holmes, um real e substancial nexo com o objetivo que se quer atingir. Paralelamente, due process of law, com caráter processual - procedural due process - garante às pessoas um procedimento judicial justo, com direito de defesa" (ADI 1.511-MC, voto do Min. Carlos Velloso, DJ 06/06/03).

13 "Ninguém será privado da liberdade ou de seus bens sem o devido processo legal" (BRASIL, 1988, LIV, art. $\left.5^{\circ}\right)$.

14 "Em outras palavras, o Estado requerido é responsável, com relação à pessoa que se encontra em seu território, não apenas pelo respeito às garantias processuais em seus próprios tribunais, mas também pela observância das garantias processuais no procedimento do Estado requerente. Sob pena de ter que recusar a cooperação internacional" (GRINOVER, 2004, p. 7).
} 
internacional na repressão criminal não pode e não deve exonerar o Estado brasileiro de velar pelo respeito aos direitos fundamentais dos indivíduos sob investigação.

A condição jurídica de investigado de um crime transnacional não pode reduzir o indivíduo a mero objeto do processo de investigação ou dele subtrair sua titularidade inalienável de direitos fundamentais, dentre os quais emerge a garantia do due process of law. O indivíduo sempre será sujeito de direitos, tutelado pelas normas internacionais e pelas garantias constitucionais e legais.

Estreitar laços internacionais a fim de se facilitar a colaboração entre as agências na cooperação para o combate aos cartéis internacionais só será salutar na medida em que se observar rigorosamente os direitos fundamentais e as garantias processuais dos investigados. 


\section{Seção II - O Direito da Concorrência no Brasil}

\section{Noções introdutórias sobre o Direito da Concorrência}

\subsection{Origens}

A defesa da concorrência, há muito, tem sido entendida como mecanismo de repressão aos abusos dos agentes econômicos pela manipulação das leis do livre mercado em detrimento de concorrentes e consumidores. A preocupação do ordenamento jurídico com a disciplina da concorrência acompanhou a história do desenvolvimento econômico. Na antiguidade grega e romana já havia regulação da prática dos agentes econômicos com o objetivo de resguardar o interesse público, ora visando evitar a manipulação dos preços e a escassez artificial dos produtos, ora concedendo monopólios a particulares como forma de assegurar fontes de receita ao Estado e coibir abusos de preços. Na Idade Média, por sua vez, o tema estava ligado à estrutura e funcionamento das corporações de ofícios.

Fábio K. Comparato (1978) afirma que o direito econômico nasce com a Primeira Guerra Mundial, que representa de fato o fim do século XIX e a superação de certa concepção clássica da guerra e da economia. A guerra, "até então uma atividade marginal, que interessava alguns grupos sociais por tradição ou profissão, e que podia se desenvolver paralelamente às outras atividades da nação", assumiu, a partir de 1914, proporções sociais e totalitárias, submetendo "a seus fins todas as classes sociais, sem exceção", de modo, que, doravante, "em período bélico, todas as funções do Estado são monopolizadas pelo conflito armado". 
Por seu turno, diante da constatação de que a guerra "não se ganha somente nas frentes de combate, mas também, e sobretudo, nos campos, nas usinas, nas fábricas e nos laboratórios", a economia transformou-se por completo sob a ação do novo fenômeno bélico. O Estado não podia permanecer "indiferente à evolução das atividades econômicas ou às decisões dos agentes da economia privada", devendo "submetê-los antes de tudo às exigências da guerra". Com isso, a atividade econômica passou a ser objeto de "regulamentação abundante, estrita e minuciosa", que em pouco tempo transformou o direito patrimonial clássico, "abolindo princípios, deformando institutos e confundindo fronteiras".

Depois da Primeira Guerra, outros fenômenos - a crise de deflação e de superprodução de 1929, a Segunda Guerra, a reconstrução que lhe sucedeu, a corrida armamentista, o movimento de concentração do poder econômico nos países industrializados e a política de desenvolvimento no Terceiro Mundo - vieram apenas confirmar a necessidade de um aparato jurídico disciplinando a atividade econômica, tendo sempre em conta os novos objetivos que apareciam $^{15}$.

Daí a observação de Ana Maria de Oliveira Nusdeo ${ }^{16}$ (2002 apud SANTOS, 2007, p. 109), no sentido de que o Estado retirou-se da vida econômica pela "porta da frente" na ordem econômica liberal, retornando pela "porta dos fundos" nos sistemas contemporâneos ${ }^{17}$.

Hodiernamente, o direito da concorrência, ou direito antitruste, como hoje se conhece, tem como ponto de partida o Sherman Act de $1890^{18}{ }^{19}$ que está amplamente

\footnotetext{
${ }^{15}$ Para maiores detalhes sobre leis e atos que marcaram a gradativa atuação do Estado na economia, no Brasil e em outros países, ver Grau (2000, p. 19-20).

16 NUSDEO, Ana Maria de Oliveira. Defesa da concorrência e globalização econômica: o controle da concentração de empresas. São Paulo: Malheiros Ed., 2002.

17 "Escorraçado da economia pelos postulados do liberalismo, o poder público dele saiu pela porta da frente, mas acabou por reingressar gradualmente pela porta dos fundos, isto é, esse reingresso não foi sistemático, nem sempre conscientemente desejado, mas fruto de uma necessidade incontornável, à falta de qualquer outra alternativa para lidar com os apontados problemas" (NUSDEO, 2002, apud SANTOS, 2007, p. 109).
} 
associado ao desenvolvimento da legislação de defesa da concorrência nos marcos do sistema capitalista. É o direito antitruste estadunidense a matriz histórica das legislações e doutrinas sobre o tema e das principais reflexões teóricas.

Assim, pode-se concluir que direito econômico surgiu a partir da Primeira Grande Guerra e foi consolidado, principalmente, na década de 1930, com o New Deal, firmando-se de forma irreversível.

Com vistas a compreender o significado das políticas de defesa da concorrência e definir o âmbito de sua atuação deve-se, em primeiro plano, identificar qual deve ser a sua finalidade, o que constitui um dos pontos mais discutidos da teoria econômica em matéria antitruste. Pretendemos, a seguir, de forma sucinta, identificar os principais pensamentos econômicos.

\subsection{O bem tutelado pelo Direito Antitruste. Principais escolas: Harvard, Chicago e Ortoliberal}

${ }^{18}$ O Sherman Act é a primeira lei federal de defesa da concorrência estadunidense. Teve como objetivo imediato o combate aos trusts (institutos concentradores típicos do direito anglo-saxão, mais eficazes que os pools e cartéis). Celli Júnior relata que "no final do século passado havia uma disseminada insatisfação popular com as redes ferroviárias que, por deterem o monopólio do transporte de bens e mercadorias, acabavam por praticar preços extremamente desproporcionais aos serviços efetivamente prestados. Além disso, muitas indústrias abusavam de seu poder econômico, buscando, de maneira concertada, sempre aumentar sua participação acionária e influência em outras indústrias estratégicas a fim de assegurar a manutenção dos preços altos. Apareceram, assim, os denominados trusts, entre os quais o mais notório tenha sido o composto pelo legendário John Rockfeller. A legislação americana visou exatamente coibir a ação desses trusts” (CELLI JUNIOR, 1996, p. 109).

19 A primeira decisão da Suprema Corte estadunidense baseada no Sherman Act foi em 1911, ordenando a dissolução da Standard Oil mediante distribuição das participações acionárias entre os sócios, em base pro rata. 
Há intensa polêmica sobre quais sejam os principais objetivos do Direito Antitruste. Tal circunstância dá-se justamente pelo fato de não haver objetivos apriorísticos para a defesa da concorrência. Serão, então, apresentadas as diversas correntes sobre o tema a fim de demonstrar que, apesar da calorosa discussão, pode-se afirmar que a política da defesa da concorrência visa tutelar ulteriormente o bem-estar do consumidor ${ }^{20}$.

Com efeito, o debate mais conhecido envolve as Escolas de Harvard e de Chicago. Os adeptos da primeira, que tem no professor Phillip Areeda ${ }^{21}$ o seu mais famoso representante, teve grande influência sobre a política de defesa da concorrência nos Estados Unidos até a década de 70 e também é chamada de estruturalista. Ela possui, como o próprio nome indica, uma preocupação com a estrutura do mercado, defendendo que a livre concorrência deve ser buscada enquanto um fim em si mesma, evitando-se que particulares venham a restringi-la. Nesse contexto, as políticas voltadas à defesa da concorrência visariam preservar o livre mercado. A corrente caracteriza-se por uma análise do funcionamento das estruturas dos mercados, baseada na relação de causalidade que veio a ser denominada de paradigma estrutura-conduta-desempenho ${ }^{22}$ (ECD).

De modo a garantir uma concorrência viável (workable competition), os seguintes elementos são analisados: (i) a estrutura, ora identificada como o grau de concentração da oferta de demanda, barreiras à entrada, tecnologia; (ii) a conduta, isto é, o comportamento dos agentes econômicos, tais como estratégias de competição, por exemplo, guerras de preço, inovação, investimentos em propaganda e marketing e em pesquisa e desenvolvimento; e (iii)

\footnotetext{
${ }^{20}$ Bem-estar do consumidor é: "Benefícios individuais decorrentes do consumo de bens e serviços. Teoricamente, o bem-estar individual é definido pela própria avaliação do indivíduo quanto a sua satisfação, em termos de preços e renda. A medição exata do bem-estar do consumidor requer, por conseguinte, informações sobre preferências individuais. Na prática, a economia do bem-estar aplicada usa a noção de renda do consumidor para medir o bem-estar do consumidor". (SISTEMA DE INFORMAÇÃO SOBRE COMÉRCIO EXTERIOR, 2012).

21 A melhor e mais compreensiva literatura sobre o antitruste é ainda hoje a obra de Areeda e Turner (1978), depois complementado por Areeda e Hovenkamp (1985).

${ }^{22}$ A referência para um compreensão mais ampla do tema é Hovenkamp (2005, p. 42-47).
} 
o desempenho ou performance, ou seja, os resultados observados no mercado como efeitos de determinadas estrutura e conduta. A observação do desempenho se vale de elementos como preço, qualidade e quantidade do produto (VISCUSI; VERNON; HARRINGTON, 2005, p. 62).

Salgado (1997, p. 16-17) sintetiza que o pensamento da Escola de Harvard indica haver uma relação de causa e efeito entre as estruturas de um mercado e o seu funcionamento. Assim, as condições básicas de oferta e de procura afetam a estrutura do mercado, que por sua vez afeta a conduta das empresas e esta é responsável por seu desempenho no mercado.

Em suma, a preocupação central da Escola de Harvard é a estrutura de mercado, preconizando a efetiva concorrência, o que, na sua interpretação, traria a garantia de possibilidade de escolha dos consumidores. Seu maior legado é a eleição do grau de concentração econômica $^{23}$ como elemento relevante de análise para a investigação concorrencial.

A Escola de Chicago ${ }^{24}$, por seu turno, tem como pressuposto básico a busca da maximização da eficiência defendendo que a melhor maneira de distribuir as riquezas se dá através dos mecanismos de mercado (POSNER, 2003) preconizando um controle mínimo sobre as concentrações econômicas ${ }^{25}$, tendo enorme impacto na doutrina e na atuação dos órgãos de defesa da concorrência dos Estados Unidos nas décadas de 70 e 80, período caracterizado por forte concentração econômica e fortalecimento dos grandes grupos econômicos. Diferentemente da Escola de Harvard que visa a manutenção do regular

\footnotetext{
${ }^{23}$ A medida de concentração mais difundida entre as autoridades de defesa da concorrência é o HHI, um índice de qual se valem as autoridades para identificar o grau de concentração de mercado e orientar os limites admissíveis resultantes de uma operação.

${ }^{24}$ Como referência para uma leitura mais aprofundada sobre o tema, ver Kovacic e Shapiro (2000, p. 53).

25 "By 1969, then, the orthodox Chicago position (well represented in writtings of Robert Bork) had crystallized: only explicit price fixing and very large horizontal mergers (merger to monopoly) were worthy of serious concern" (POSNER, 1979, p. 933).
} 
funcionamento do mercado, esta corrente entende que o valor essencial protegido pela política de defesa da concorrência é o bem-estar do consumidor (consumer welfare), aliado à promoção da eficiência, ou seja, busca a habilidade de produzir produtos a custos menores e, assim, reduzir o preço final. Seu principal expoente, Richard Posner, procurou fazer da análise econômica do Direito uma disciplina autônoma, desenvolvendo a possibilidade de todo o Direito ser analisado economicamente, uma vez que muitas instituições jurídicas seriam construídas sobre essa lógica. A hipótese básica de Posner era a de que as instituições jurídicas podem ser analisadas examinando-se em que medida fomentam a produtividade da economia e, assim, elegeu a eficiência econômica como valor absoluto que deveria permear toda e qualquer a análise antitruste.

Sob a denominação Post-Chicago Economics (PCE), doutrinadores desenvolveram novas teorias criticando as premissas das concepções de Chicago, postulando a necessidade de uma maior utilização de medidas interventivas (BAKER, 2002) e relativizando o papel das eficiências econômicas na execução da política de defesa da concorrência. A maior contestação da doutrina da Escola de Chicago é a Escola Ortoliberal (ou Escola de Freiburg) que possui este nome porque, por um lado, é liberal no sentido de preconizar um Estado menos intervencionista e, por outro, entende ser deletério para a democracia em geral e para o direito de escolha do consumidor em específico o excesso de concentração (e o elevado poder econômico). A corrente que tem seu ícone em Jonathan B. Baker estabelece como objeto do direito da defesa da concorrência a livre concorrência (SHUARTZ, 1994, p. 61) a ser alcançada pela proteção ao consumidor.

Afirma-se que hoje impera o entendimento de que não existe uma visão abstrata das finalidades do direito da concorrência, uma vez que as suas normas dependem de 
premissas assumidas sobre mercados e governo, ou seja, dependem da política econômica em vigor em uma determinada época e em um determinado local ${ }^{26}$.

Este trabalho não tem a pretensão de aprofundar-se nas diversas escolas e ramos que professam a necessidade de se realizar uma análise econômica do Direito. Ainda assim, é importante verificar que a utilização da teoria econômica para a solução de conflitos jurídicos, notadamente no direito da concorrência é, em maior ou menor grau, uma ferramenta existente e útil.

\subsection{A evolução do Direito Antitruste no Brasil}

A Constituição Federal de 1934 foi a primeira a tratar da garantia à ordem econômica $^{27}$, prevendo de forma inaugural também disposições sobre a garantia da liberdade econômica, liberdade de iniciativa e proteção à economia popular. Como ponderou Pontes de Miranda (1946, p. 501), a Carta Magna de 1934 trazia implicitamente o princípio da repressão ao abuso do poder econômico e a critica no sentido de sua falta de orientações mais expressas:

As partes programáticas das Constituições burguesas de após-guerra não conseguem dar fins precisos ao Estado (menos ainda o fim único, como ocorreu com a Constituição soviética). São Constituições de intenções teleológicas, que apenas

\footnotetext{
${ }^{26}$ Nesse sentido, ver Whish e Bailey (2005, p. 17-23).

27 "A ordem econômica deve ser organizada conforme os princípios da justiça e as necessidades da vida nacional de modo que possibilite a todos existência digna. Dentro desses limites é garantida a liberdade econômica" (BRASIL, 1934, art. 115).
} 
atenuam o liberalismo sistemático do tipo constitucional do Século XIX e fim do Século XVIII (MIRANDA, 1946, p.13-14).

A Constituição de $1937^{28}$, imposta após o golpe de Estado promovido por Getúlio Vargas, aprofundou ainda mais o capítulo da ordem econômica instituído. Consolidou de vez o Estado intervencionista, no seu artigo $135^{29}$, ao prever a possibilidade de intervenção mediata ou imediata que, inclusive, revestisse a forma de gestão direta. De fato, a constituição ditatorial, fundada no espírito fascista da época, desenhou um Estado Novo "arbitrário despojado de quaisquer controles jurídicos” (BASTOS; MARTINS, 2000, p. 340).

No campo infraconstitucional, o período foi rico em intervenção realizada principalmente através de Decretos-Lei. Com efeito, em 1938, a edição do Decreto-Lei n. 869 introduziu pela primeira vez no ordenamento jurídico brasileiro normas de defesa da concorrência, como por exemplo, a vedação ao açambarcamento de mercadorias, à fixação de preços mediante acordos, à imposição de exclusividade, à prática de preço abusivo e à venda abaixo do preço de custo (HUNGRIA, 1939) ${ }^{30}$. É de se notar também a edição do Decreto-Lei n. 1.716 de 1939 que dispunha sobre a configuração e julgamento dos crimes contra a economia popular. Por fim, por influência do então Ministro da Justiça, Agamenon Magalhães, conhecido por sua luta contra os trustes e por seu posicionamento nacionalista, foi editado o Decreto-Lei n. 7.666/45 ou "Lei Malaia" que dispunha sobre "atos contrários à ordem moral e econômica" tendo sido a primeira lei dedicada exclusivamente à proteção do

\footnotetext{
${ }^{28}$ Antes desse período, alerta-nos Forgioni (1996): “em termos de disciplina da concorrência interna pouco há nesse período que possa ser estudado". Para uma análise mais detalhada, ver Forgioni (1996, p. 59-66).

29 "Na iniciativa individual, no poder de criação, de organização e de invenção do indivíduo, exercido nos limites do bem público, funda-se a riqueza e a prosperidade nacional. A intervenção do Estado no domínio econômico só se legitima para suprir as deficiências da iniciativa individual e coordenar os fatores da produção, de maneira a evitar ou resolver os seus conflitos e introduzir no jogo das competições individuais o pensamento dos interesses da Nação, representados pelo Estado. A intervenção no domínio econômico poderá ser mediata e imediata, revestindo a forma do controle, do estímulo ou da gestão direta" (BRASIL, 1937, art. 135).

${ }^{30} \mathrm{O}$ professor Hungria também é autor da redação do referido decreto-lei.
} 
mercado e à repressão do abuso do poder econômico. Disciplinando a matéria de forma específica, preconizou a intervenção do Estado para garantir a liberdade econômica entre os agentes e previu a estruturação da "Comissão Administrativa de Defesa Econômica" (CADE). Em razão da queda do Governo Getúlio Vargas em 1945, esse Decreto-Lei, porém, teve duração de apenas 3 meses e a Comissão de Defesa Econômica não chegou a ser implantada.

Foi somente a Constituição Federal de 1946 que consagrou a expressão "abuso do poder econômico" em seu art. $148^{31}$. Houve na sequência, a promulgação de outras Leis ${ }^{32}$ também com intuito de se assegurar a livre concorrência mediante a intervenção do Estado no domínio econômico.

A Constituição Federal de 1967, pós-golpe militar de 1964, e com a redação dada pela Emenda Constitucional de n. 1/69, elevou a repressão ao abuso do poder econômico inclusive reforçando seu caráter penal (FERRAZ JUNIOR, 1992, p. 179), juntamente com a liberdade de iniciativa e a função social da propriedade, à categoria de princípio da ordem econômica e social (FARIA, 1990, p. 107). Cristalizou o artigo 157:

\footnotetext{
31 “A lei reprimirá toda e qualquer forma de abuso do poder econômico, inclusive as uniões ou agrupamentos de empresas individuais ou sociais, seja qual for a sua natureza, que tenham por fim dominar os mercados nacionais, eliminar a concorrência e aumentar arbitrariamente os lucros" (BRASIL, 1946, art. 148).

${ }^{32}$ Por exemplo, a Lei dos crimes contra a ordem popular (Lei n. 1.521 de 1951) que em seu art. $3^{\circ}$ definiu o crime de "formação de cartel ou associação cujo propósito era suprimir ou dificultar a livre concorrência". A Lei n. 1.522 de 1951 que autorizava o Governo Federal a intervir no domínio econômico para assegurar a livre distribuição de produtos necessários ao consumo do povo. A Lei de n. 4.137 de 1962, inspirada na Lei Malaia, que disciplinava a repressão do abuso ao poder econômico criando o Conselho Administrativo de Defesa Econômica. Sobre a Lei, Bastos (1997) afirma que "O longo período que sucede à criação do CADE, dominado por partes interventivas do Estado na econômica e no tabelamento de preços (1962/1990), restringiu os seus âmbitos de atuação e consolidou práticas administrativas mais voltadas para resguardar a reserva de mercado e a intervenção econômica do Estado". Segundo Forgioni (1996, p. 95), foram "vinte e nove anos de vigência desprovida de eficácia material". Com isso, o CADE passou a ser visto como um órgão pouco operante e também de pouca importância. Na sequência, houve a edição das Leis Delegadas n. 2 e n. 5 de 26 de 1962. (BASTOS, 1997, p. 107).
} 
A ordem econômica e social tem por fim realizar o desenvolvimento nacional e a justiça social, com base nos seguintes princípios: (...)

V - repressão ao abuso do poder econômico, caracterizado pelo domínio dos mercados, a eliminação da concorrência e o aumento arbitrário dos lucros. (BRASIL, 1967, art. 157)

\section{Em 1990, foi promulgada a Lei n. 8.137 (BRASIL, 1990) que definiu dos crimes}

contra a ordem tributária, econômica e contra as relações de consumo, mantendo a criminalização das práticas anticoncorrencias elencadas em seus dispositivos $4^{33}, 5^{34}$ e $6^{35}$.

33 "Constitui crime contra a ordem econômica: I - abusar do poder econômico, dominando o mercado ou eliminando, total ou parcialmente, a concorrência mediante: a) ajuste ou acordo de empresas; b) aquisição de acervos de empresas ou cotas, ações, títulos ou direitos; c) coalizão, incorporação, fusão ou integração de empresas; d) concentração de ações, títulos, cotas, ou direitos em poder de empresa, empresas coligadas ou controladas, ou pessoas físicas; e) cessação parcial ou total das atividades da empresa; f) impedimento à constituição, funcionamento ou desenvolvimento de empresa concorrente. II - formar acordo, convênio, ajuste ou aliança entre ofertantes, visando: a) à fixação artificial de preços ou quantidades vendidas ou produzidas; b) ao controle regionalizado do mercado por empresa ou grupo de empresas; c) ao controle, em detrimento da concorrência, de rede de distribuição ou de fornecedores. III - discriminar preços de bens ou de prestação de serviços por ajustes ou acordo de grupo econômico, com o fim de estabelecer monopólio, ou de eliminar, total ou parcialmente, a concorrência; IV - açambarcar, sonegar, destruir ou inutilizar bens de produção ou de consumo, com o fim de estabelecer monopólio ou de eliminar, total ou parcialmente, a concorrência; V - provocar oscilação de preços em detrimento de empresa concorrente ou vendedor de matéria-prima, mediante ajuste ou acordo, ou por outro meio fraudulento; VI - vender mercadorias abaixo do preço de custo, com o fim de impedir a concorrência; VII - elevar sem justa causa o preço de bem ou serviço, valendo-se de posição dominante no mercado. (Redação dada pela Lei n. 8.884, de 11.6.1994). Pena - reclusão, de 2 (dois) a 5 (cinco) anos, ou multa" (BRASIL, 1990, art. $4^{\circ}$ ).

34 "Constitui crime da mesma natureza: I - exigir exclusividade de propaganda, transmissão ou difusão de publicidade, em detrimento de concorrência; II - subordinar a venda de bem ou a utilização de serviço à aquisição de outro bem, ou ao uso de determinado serviço; III - sujeitar a venda de bem ou a utilização de serviço à aquisição de quantidade arbitrariamente determinada; IV - recusar-se, sem justa causa, o diretor, administrador, ou gerente de empresa a prestar à autoridade competente ou prestá-la de modo inexato, informando sobre o custo de produção ou preço de venda. Pena - detenção, de 2 (dois) a 5 (cinco) anos, ou multa. Parágrafo único. A falta de atendimento da exigência da autoridade, no prazo de 10 (dez) dias, que poderá ser convertido em horas em razão da maior ou menor complexidade da matéria ou da dificuldade quanto ao atendimento da exigência, caracteriza a infração prevista no inciso IV" (BRASIL, 1990, art. $5^{\circ}$ ).

35 "Constitui crime da mesma natureza: I - vender ou oferecer à venda mercadoria, ou contratar ou oferecer serviço, por preço superior ao oficialmente tabelado, ao regime legal de controle; II - aplicar fórmula de reajustamento de preços ou indexação de contrato proibida, ou diversa daquela que for legalmente estabelecida, ou fixada por autoridade competente; III - exigir, cobrar ou receber qualquer vantagem ou importância adicional de preço tabelado, congelado, administrado, fixado ou controlado pelo Poder Público, inclusive por meio da 
Criada em resposta à transformação econômica que vinha sofrendo o Brasil, notadamente a liberalização econômica da década de 90 , e em razão da inoperância do diploma anterior ${ }^{36}$, foi sancionada a Lei n. 8.158/91. A referida lei previu investigações mais eficazes e céleres criando a Secretaria Nacional de Direito Econômico responsável por "apurar, prevenir e reprimir os abusos do poder econômico, por intermédio do Conselho Administrativo de Defesa Econômica", para "zelar pelos direito e interesses dos consumidores, promovendo as medidas necessárias para assegurá-los", e para "aplicar a legislação de intervenção no domínio econômico para assegurar a livre distribuição de bens e serviços”. Também manteve as normas definidoras de ilícitos e sanções constantes da Lei n. 4.137/1962, assim, o Ministério da Justiça, o CADE e a SNDE "lhe dando suporte de pessoal e administrativo" passaram a atuar de forma integrada - e há quem diga superposta e em prejuízo da celeridade das

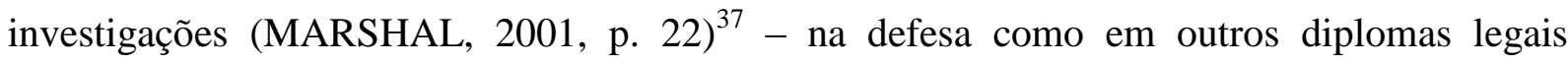
relativos a práticas de abuso de poder econômico.

Trazendo a sistematização da matéria e seu aperfeiçoamento na esfera legislativa (FORGIONI, 1996, p. 101), a Lei n. 8.884/94 revogou as Leis n. 4.137/62 e n. 8.158/91 e também alterou a Lei n. 8.137/90. Em 29 de maio de 2012, entrou em vigor a Lei n. 12.529 de 30 de novembro de 2011 que revogou a Lei n. 8.884/94 e a Lei n. 9.781/99, alterou a Lei n. 8.137/90, o Decreto-Lei n. 3.689/41 e a Lei de n. 7.347/85. As principais características relevantes para o presente trabalho trazidas pela Lei n. 8.884/94 e mantidas pela 12.529/11, que redefiniram os parâmetros da política brasileira concorrencial serão estudadas no Item 3 desta Seção.

adoção ou de aumento de taxa ou outro percentual, incidente sobre qualquer contratação. Pena - detenção, de 1 (um) a 4 (quatro) anos, ou multa" (BRASIL, 1990, art. $6^{\circ}$ ).

${ }^{36}$ Para o professor Tércio Sampaio Ferraz Júnior (1992, p. 181), "O sistema anterior previsto na Lei n. 4.137/63 era inoperante e prolongado, pois os processos tinham a duração média de dois anos, e, assim sendo, não respondiam às expectativas do novo ambiente econômico".

${ }^{37}$ Nos termos da Lei n. 8.158, os atos de concentração passaram a ser apreciados pela SNDE, em caráter excepcional pelo CADE e ainda tendo que serem homologados pelo Ministério da Justiça. 


\section{O advento da Constituição Federal de 1998}

A Constituição de 1988, por sua vez, em vez de tratar da repressão ao abuso do poder econômico, recuperou a linguagem da Carta de 1946 de finalidade ao estabelecer que "a lei reprimirá o abuso do poder econômico que vise a dominação dos mercados, a eliminação da concorrência e o aumento arbitrário dos lucros" (BRASIL, 1988, art. 173), afastando assim a conotação penal pela caracterização do abuso. Observa-se, com isso, que o ordenamento jurídico reprime não a existência do poder econômico, per se, mas sim o seu abuso ${ }^{38}$.

A livre concorrência foi elevada, pela primeira vez, à categoria de princípio econômico constitucional (artigo $170^{39}$ ) a ser observada na realização da ordem econômica juntamente com outros princípios, tais como, a soberania nacional, a propriedade privada, a função social da propriedade, a defesa do consumidor e do meio ambiente, a redução das desigualdades regionais e sociais, a busca pelo pleno emprego.

Hoje, a fundamentação constitucional para as normas antitruste está no inciso IV do art. 170 e no $\S 4^{\circ}$ do art. 173 da Constituição Federal e justifica a intervenção estatal na atividade econômica por alçar o mercado à condição de bem público.

\footnotetext{
38 “O que se condena é seu excesso, seu exercício abusivo de maneira a prejudicar a regular operação das leis de demanda e oferta vigentes no mercado. Cabe, então, ao Estado intervir para coibir o abuso". (SILVA, 1990, p. 16).

39 “A ordem econômica, fundada na valorização do trabalho humano e na livre iniciativa, tem por fim assegurar a todos existência digna, conforme os ditames da justiça social, observados os seguintes princípios: (...) IV - a livre concorrência”" (BRASIL, 1988, art. 170).
} 


\subsection{Contextualização constitucional do bem tutelado: princípios da Ordem Econômica e instrumentalidade da defesa da concorrência}

Para a compreensão do significado da livre concorrência no sistema brasileiro é preciso que se faça sua análise à luz dos preceitos constitucionais uma vez que são eles quem o estabelecem enquanto princípio, norteiam sua convivência com os demais princípios e também indicam a forma que deve ser interpretado e implementado, uma vez que a carta não traz seu conceito, deixando tal tarefa ao legislador e ao intérprete. Tais esclarecimentos são importantes para que se perceba o princípio da livre concorrência enquanto um espectro de um contexto socialmente valioso. Neste sentido, é já conhecida a lição do professor E. Grau de que "jamais se aplica uma norma jurídica, mas sim o direito, não se interpretam normas constitucionais, isoladamente, mas sim a Constituição, no seu todo. Não se interpreta a Constituição em tiras, aos pedaços" (GRAU, 2000, p. 179).

A liberdade de empreender, núcleo da livre iniciativa, pressupõe outra liberdade, a de contratar, núcleo da autonomia da vontade. Por sua vez, a liberdade de concorrer, núcleo do princípio da livre concorrência (BRASIL, 1988, art. 170, inc. IV), pressupõe outra liberdade, qual seja, a de escolha do consumidor, núcleo do princípio da defesa do consumidor (BRASIL, 1988, art. 170, inc. V). Contudo, todas estas liberdades, bem como todos os seus pressupostos, encontram seus limites para a busca de um fim maior, notadamente, a garantia da "dignidade da pessoa humana". No conceito de Grau (2000, p. 222), essa convergência significa que "a ordem econômica mencionada pelo art. 170, caput do texto constitucional isto é, mundo do ser, relações econômicas ou atividade econômica (em sentido amplo) - deve ser dinamizada tendo em vista a promoção da existência digna de que todos devem gozar".

Percebe-se assim o caráter instrumental dos princípios que norteiam a ordem econômica que estão insertos no fim geral e maior, qual seja, "assegurar a todos existência digna, conforme os ditames da justiça social" (FORGIONI, 1998, p. 170). Nessa linha, a "valorização do trabalho humano", acompanhada da "livre iniciativa", que, em verdade, "é um 
modo de expressão do trabalho e, por isso mesmo, corolário da valorização do trabalho" (GRAU, 2000, p. 231), ambas previstas no caput do art. 170 da Constituição como fundamentos da ordem econômica, são condições para que se assegure a "dignidade da pessoa humana".

Forgioni (2005, p. 193) afirma que "No Brasil, a tutela da concorrência não é, portanto, um fim em si mesma e poderá ser afastada quando o escopo maior perseguido pelo sistema assim o exigir". Nas palavras de Salomão Filho (2001, p. 48), "No Brasil, o direito da concorrência tem de servir como uma garantia mínima de equilíbrio na ordem econômica”.

Afigura-se, assim, a livre concorrência enquanto princípio complementar ao da livre iniciativa, ambos voltados à preservação do modo de produção capitalista, através da tutela do consumidor a qual deve também ser encarada, em última instância, como garantidora da dignidade da pessoa humana. Evidencia-se, assim, a preocupação fundada no pensamento da Escola Ortoliberal com a manutenção de um sistema no qual haja uma igualdade de condições mínimas de concorrência entre seus participantes de modo que os benefícios da concorrência se estendam a todos.

No sentido da complementaridade dos princípios da livre concorrência e da livre iniciativa, preleciona José Afonso da Silva (1990, p. 16):

Os dois dispositivos se complementam no mesmo objetivo. Visam tutelar o sistema de livre mercado e, especialmente, proteger a livre concorrência, contra a tendência açambarcadora da concentração e monopólio capitalistas.

Percebe-se, assim, que os princípios da livre iniciativa e da livre concorrência não são absolutos nem constituem um fim em si mesmos. Devem ser harmonizados com outros princípios constitucionais e outros tipos de políticas públicas para um fim maior, qual seja, "assegurar a todos existência digna, conforme os ditames da justiça social” (FORGIONI, 2005, p. 49). 


\section{A Lei 8.884/1994: características gerais, esferas de atuação e autoridades} responsáveis pela sua aplicação. Sua revogação pela Lei 12.529/11 (“Diploma Brasileiro Antitruste")

Como visto, o ápice da valorização da defesa da concorrência no Brasil deu-se através de sua disciplina pela Lei n. 8.884 de 11 de junho de 1994. A referida lei deu a três órgãos a função de proteção da ordem econômica, princípio tutelado por nossa Constituição Federal, e dispôs sobre a prevenção e a repressão às infrações contra a mesma. Assim, a referida lei transformou o Conselho Administrativo de Defesa Econômica (CADE) em autarquia vinculada ao Ministério da Justiça, sendo o órgão responsável em última instância, na esfera administrativa, pela decisão final sobre as concentrações e investigações de condutas anticoncorrencias. A lei também elegeu a Secretaria de Direito Econômico $\left(\mathrm{SDE}^{40}\right)$ do Ministério da Justiça e a Secretaria de Acompanhamento Econômico (SEAE) do Ministério da Fazenda enquanto agências que realizam as análises das concentrações e condutas, e, emitem seus pareceres técnicos não vinculativos ao CADE.

Foram essas as três autoridades principais ${ }^{41}$ que compuseram o Sistema Brasileiro de Defesa da Concorrência (SBDC) até 29 de maio de 2012, quando se deu a revogação da Lei de n. 8.884/94 pelo atual Diploma Antitruste Brasileiro - Lei n. 12.529/11 - e que foram as

\footnotetext{
40 Frise-se ainda que a SDE conta em sua estrutura com o Departamento de Proteção e Defesa da Ordem Econômica (DPDE) e com o Departamento de Proteção e Defesa do consumidor (DPDC).

${ }^{41}$ Vale dizer que o art. 15 da Lei n. 12.529/11, antigo art. 10 da Lei n. 8.884/94, também prevê a criação e as funções da Procuradoria do CADE ("PROCADE"). A PROCADE foi criada para permitir o ingresso do CADE em juízo além de auxiliar o órgão em questões processuais que permeiam sua atuação. O art. 20 da Lei n. 12.529/11 estabelece que o Ministério Público Federal emita parecer, nos processos administrativos, para imposição de sanções administrativas por infrações à ordem econômica, de ofício ou a requerimento do Conselheiro-Relator. Nos termos revogados da Lei n. 8.884/94, a prerrogativa do Ministério Público Federal “em oficiar nos processos sujeitos à apreciação do CADE” estava estabelecida no art. 12 da Lei.
} 
responsáveis pela proteção da livre concorrência a qual é exercida de três formas: (i) preventiva; (ii) repressiva e (iii) advocacia da concorrência.

No chamado "controle de estruturas", em sua função preventiva, caráter inclusive já estabelecido pelo art. caput do art. $174^{42}$ da Carta de 1988, o SBDC analisava eventuais impactos anticompetitivos decorrentes de fusões e aquisições (concentrações) visando assegurar o bem-estar do consumidor final e monitora os comportamentos dos agentes.

Em sua função repressiva, caráter já previsto pelo art. $173 \S 4^{\circ}$ da Carta de 1988, o SBDC pune as práticas que possam eliminar a concorrência existente em um determinado mercado.

Como se vê, ao SBDC foi conferido o poder-dever de não somente reprimir a condutas anticoncorrenciais, mas também de agir preventivamente - no controle das estruturas de mercado. Conforme colocado por Salomão Filho (2007, p. 156) ao tratar desses dois aspectos, enquanto o preventivo diz respeito à necessidade de autorização para a formação de estruturas que possam "vir a gozar de poder de mercado", o controle repressivo visa a "regulamentar e sancionar o chamado abuso do poder econômico em suas mais variadas formas". Desse modo, o direito concorrencial deve estabelecer na esfera do controle das estruturas regras de condutas que preservem o sistema e garantam ao máximo o autocontrole do mercado (SALOMÃO FILHO, 2001, p 49).

Com efeito, a Lei n. 8.884/94 encampa o controle preventivo de estruturas e condutas (art. 14, incisos I e II, e art. de 54 a 58) e repressivo de condutas (artigos 15 a 53 ). Enquanto a tipificação das estruturas que devem ser submetidas para autorização do CADE

\footnotetext{
42 "Como agente normativo e regulador da atividade econômica, o Estado exercerá, na forma da lei, as funções de fiscalização, incentivo e planejamento, sendo este determinante para o setor público e indicativo para o setor privado" (BRASIL, 1988, art. 174).
} 
está prevista no art. 54 caput e $\S 3^{\circ}$, a tipificação das práticas que devem der reprimidas está prevista na conjugação do art. 20 e incisos com o art. 21 e incisos. No presente trabalho, trataremos da prática de cartel sob o enfoque do controle de condutas. Retomaremos em maiores detalhes o enquadramento legal da conduta no item 1.2 da Seção III abaixo.

Por fim, por meio da advocacia da concorrência ou ação educativa das autoridades, a lei (por exemplo, art. 7 incisos X e XVIII e art. XIV e XV) prevê que o SBDC difunda a cultura da concorrência e do conhecimento a respeito de suas principais orientações, benefícios da livre concorrência, etc.

Com efeito, aos 30 de novembro de 2011, a Lei de n. 12.529/2011 foi sancionada e reestruturou o Sistema Brasileiro de Defesa da Concorrência e deu outras providências. A Lei entrou em vigor em 29 de maio de 2012, e implementou uma série de transformações relevantes na política brasileira de defesa da concorrência, dentre elas, unificação das estruturas de instrução e julgamento dos processos e a adoção do sistema de análise prévia de atos de concentração. A lei institui que o SBDC fosse formado pelo CADE e pela SEAE. Em sua estrutura organizacional, o CADE tem a seguinte configuração: Tribunal Administrativo de Defesa Econômica; Superintendência-Geral; e Departamento de Estudos Econômicos. Nesta nova configuração, o CADE ficou responsável pela proteção da livre concorrência em suas formas preventiva e repressiva, enquanto a SEAE ficou responsável por exercer o papel de advocacia da concorrência Ou seja, no que se refere às competências da antiga SEAE, a Secretaria deixou de instruir os atos de concentração e passou a opinar sobre os eventuais efeitos concorrenciais de atos normativos a serem adotados por entidades públicas ou privadas. Especialmente no campo da defesa comercial, a SEAE deve se manifestar sobre os impactos sobre a livre concorrência de medidas relativas às atividades de alteração tarifária, ao acesso a mercados e à defesa comercial.

Feitos os esclarecimentos necessários de natureza conceitual sobre a justificativa das políticas de defesa da concorrência, os princípios constitucionais que a devem nortear e que delimitam o seu espaço de atuação, passemos para a abordagem mais específica sobre 
alguns conceitos de cartel, sua classificação e principais características, sua previsão na legislação brasileira e na comparada. 


\section{Seção III - Cartéis: "the supreme evil of antitrust ${ }^{43 \text { ", }}$}

\section{Nota introdutória e a classificação de cartel adotada por este trabalho}

Dentro da análise comportamental dos agentes econômicos, pode-se identificar dois tipos gerais de condutas anticompetitivas diferenciados pelos efeitos e objeto (SALOMÃO FILHO, 2001, p. 156): as condutas excludentes (ex ludere) que têm por objetivo excluir os concorrentes do "jogo concorrencial" e as condutas colusivas (co ludere) que têm por objetivo trazer o concorrente para dentro do jogo de dominação de mercado. No primeiro tipo, o intuito da dominação de determinado mercado se faz via exclusão dos demais players (e.g. imposição de preços predatórios, negociação compulsória). No segundo tipo, o intuito de dominação de mercado ocorre via a reunião entre os agentes econômicos em uma conduta concertada visando a eliminação de outros concorrentes não agregados ao pacto ou visando que os consumidores não tenham opção de preço ou de serviço prestado. A seguir, estudaremos o segundo tipo de conduta, também conhecido como cartel ${ }^{44}$, especificamente, o internacional.

${ }^{43}$ Assim considerado pela Suprema Corte dos Estados Unidos no caso Verizon Communications versus Curtis V.
Trinko LLP, 540, US. 398 (2004)
${ }^{44}$ Importante mencionar que a teoria econômica admite que nem todos os acordos entre concorrentes são
prejudiciais ao bem-estar econômico. Assim, é possível haver o "bom" e o "mau" cartel. No primeiro caso, que
não é chamado propriamente de "cartel", estão os acordos que visam aumentar a eficiência da produção, diminuir
riscos, melhorar a qualidade dos produtos, ou então contribuir para a realização de pesquisa e desenvolvimento.
Neste sentido, há precedentes de aceitação pela Suprema Corte dos Estados Unidos de condutas cooperativas
entre concorrentes com eventual implicação sobre preços, desde que não exclusivamente com essa finalidade,
após uma análise específica destinada ao balanço específico de seus efeitos pró e anticompetitivos - rule of
reason. Um exemplo em 1918 foi o caso da Chicago Board of Trade em que a adoção de uma regra de transações
a preço fixo no pregão foi considerada adequada para incentivar sua realização no período normal de operações e
minimizar comportamentos oportunistas - free riding - para evitar o pagamento das taxas. Entretanto, o presente
estudo tão somente se refere aos acordos horizontais deletérios à economia. O primeiro, diferentemente do
segundo, não é considerado um ilícito. A separação entre um acordo lícito e ilícito incide na determinação do 
Os cartéis internacionais são explicitamente aqueles acordos privados, tácitos ou expressos, entre concorrentes ou produtores ou fornecedores de múltiplas economias que visam a fixação de preços, limitação da produção e a divisão de mercado. Os cartéis internacionais operam em escala mundial e são formados para determinarem variáveis estritamente concorrenciais (preço, quantidade produzida, divisão geográfica de mercados ou divisão de mercadorias produzidas) reduzindo, assim, a competição dentro de determinado segmento industrial.

A literatura aponta algumas características próprias desse tipo de acordo tais como, envolvimento de altos executivos no conluio e ciência da ilicitude da prática; uso de associações comerciais e empresas fantasmas para acobertar as reuniões; monitoramento do acordo para que ajam de forma "honesta", o que pode incluir a figura de um auditor; uso de esquema de compensação (SPRATLING, 1999).

The most startling characteristic of the multinational cartels we have prosecuted is how cold blooded and bold they are...(...) They go great lengths to cover up their actions such as using code names with one another, meeting is secret venues around the world, creating false covers, facially legal justifications for their meetings, using home phone numbers to contact one another, and giving explicit instructions to destroy any evidence of the conspiracy ${ }^{45}$ (BARNETT, 2006).

A OCDE (1998) reconheceu que os cartéis são considerados as formas de conduta anticompetitiva mais graves e danosas para o livre comércio internacional e para o desenvolvimento da economia mundial uma vez que prejudicam os consumidores em diversos

prejuízo (real ou potencial) à livre concorrência. O Professor Calixto Salomão Filho (2001, p. 57) afirma que o valor jurídico a ser preservado contra a prática de cartel é a concorrência: "É, portanto, o objetivo realizável de dominar o mercado através de ajuste entre empresas fator chave para caracterização da antijuridicidade".

${ }^{45}$ Tradução livre "A característica mais surpreendente dos cartéis internacionais que podemos indicar é o sangue frio e a ousadia (...) percorrem grandes distancias para encobrir suas ações como a utilização de codinomes, encontros em locais secretos ao redor do mundo, criando falsas identidades, apresentando justificativas legais para suas reuniões, usando números de telefone da própria residência para entrar em contato com um outro e dando instruções explícitas para destruir quaisquer provas da conspiração. 
países, aumentando os preços e restringindo a oferta, tornando as mercadorias e serviços completamente impossíveis para a compra de alguns ou aumentando os valores de forma desnecessária para outros.

No âmbito internacional, os cartéis podem se classificar em (EVENETT; LEVENSTEIN; SUSLOW, 2001, p. 1222-1223): (1) cartéis clássicos (hard core cartels), em

que seus membros são agentes econômicos da iniciativa privada; (2) os cartéis de exportação ${ }^{46}$ que se subdividem em (2.a) cartéis privados de exportação, os quais também formados por agentes econômicos da iniciativa privada mas com sua atuação voltada para o mercado externo e (2.b) cartéis de exportação ligados ao Estado; e (3) cartéis de importação. Apenas o primeiro servirá de objeto deste estudo por guardar pertinência ao tema ora abordado.

\section{Aspectos gerais do Cartel e seus deletérios efeitos}

O cartel consiste num acordo entre agentes econômicos em que se estabelece o preço de determinado produto ou serviço ou ainda em que se dividem os mercados. Tem como objetivo final elevar os preços ao consumidor, por meio da redução da concorrência, aproximando sua lucratividade ao que seria alcançado em situação de monopólio (um só ofertante). Ao aumentar preços e restringir oferta, o cartel torna os bens e serviços mais caros ou indisponíveis além de também reduzir o incentivo às inovações. Assim, ao reduzir a concorrência entre as empresas, prejudicando os consumidores, os cartéis são considerados a mais grave lesão a ela.

\footnotetext{
${ }^{46}$ Denomina-se cartel de exportação a situação em que exportadores de um mesmo mercado associam-se a fim de travar concorrência internacional, bem como maximizar os benefícios decorrentes da economia de escala (FORGIONI, 2005, p. 416).
} 
Segundo estimativas da OCDE (1998), os cartéis geram um sobrepreço estimado em média de 10 a $20 \%$ se comparados ao preço de um mercado competitivo causando enormes prejuízos aos consumidores. Na pesquisa conduzida para o período de 1996 e 2000, os países apontaram para a existência de 119 cartéis, sendo que na maioria desses casos não foi possível quantificar ao certo os prejuízos causados. Mesmo assim, identificou-se que os 16 maiores cartéis afetaram o comércio internacional em mais de US\$ 55 bilhões. A pesquisa mostrou também que o sobrepreço gerado por tais acordos varia significativamente, mas em alguns casos pode chegar em até $50 \%$. A OCDE reconhece ${ }^{47}$ que são considerados as formas de conduta anticompetitiva mais graves e danosas para o livre comércio internacional e para o desenvolvimento da economia mundial uma vez que prejudicam os consumidores em diversos países.

Ainda sobre o impacto de um cartel na economia, vale finalizar com trecho de publicação da OCDE (2003) sobre o tema ${ }^{48}$ :

Cartéis prejudicam consumidores e têm efeitos nocivos sobre a eficiência econômica. Um cartel bem-sucedido eleva os preços acima do nível competitivo e reduz a produção. Os consumidores (o que inclui o setor privado e governos) escolhem entre não pagar o preço mais alto por algum ou todo o produto cartelizado que eles desejam, e, portanto, diminuem o consumo, ou eles pagam o preço de cartel e, inconscientemente, transferem renda para os operadores de cartel. Os cartéis geram desperdício e ineficiência. Além do mais, o cartel protege os seus membros de se exporem plenamente às forças do mercado, reduzindo a pressão sobre eles para controlar custos e inovar. Todos esses efeitos prejudicam a eficiência em uma economia de mercado.

${ }^{47} \mathrm{O}$ Report on the Nature and Impact of Hard Core Cartels and Sanctions against Cartels under National Competition Laws está disponível no site da OCDE: www.oecd.org/daf/competition.

48 Tradução livre de "Cartels harm consumers and have pernicious effects on economic efficiency. A successful cartel raises price above the competitive level and reduces output. Consumers (which includes business and governments) choose either not to pay the higher price for some or all of the cartelised product that they desire, thus forgoing the product, or they pay the cartel price and therby unknowingly transfer wealth to the cartel operators. Further, a cartel shelters its members from full exposure to market forces, reducing pressures on them to control costs and to innovate. All of these effects harm efficiency in a market economy" (OCDE, 2003). 


\subsection{Conceito: revisão doutrinária e jurisprudencial à espécie}

Um primeiro delineamento sobre a natureza do cartel pode ser encontrado na lição do professor Nusdeo, para o qual essa modalidade de acordo trata:

de um acordo entre empresas que passam a adotar decisões ou políticas comuns quanto a todos ou a um determinado aspecto de suas atividades. Por se tratar de um acordo, as empresas nele envolvidas não perdem a sua autonomia ou a sua individualidade. Elas apenas se submetem aos termos do acordo no seu particular âmbito de aplicação (NUSDEO, 2001, p. 315).

Nas palavras do Professor Calixto Salomão Filho:

(...) Esta forma de organização empresarial se caracteriza pela uniformização de certos comportamentos ou pela realização de atividade conjunta, sem interferir na autonomia de cada empresa que permanece substancialmente independente naqueles aspectos de atividade não sujeitos ao acordo (SALOMÃO, 2001, p. 227).

O cartel, portanto, é um acordo realizado entre empresas concorrentes com o objetivo de restringir a concorrência. Seus membros partem da premissa de que o comportamento cooperativo é mais proveitoso do que o autônomo e assim estabelecem entre si níveis de produção e fixam preços ${ }^{49}$ com vistas a alcançar uma lucratividade que somente poderia ser obtida em uma situação de monopólio ${ }^{50} 51$.

49 "Is an agreement among otherwise competing firms to reduce output to agreed upon levels or sell at an agreed upon price" (HOVENKAMP, 2005, p. 144).

50 "The firms acting in concert can earn monopoly profits just as single monopolist". (Ibid., p. 58)

${ }^{51} \mathrm{O}$ monopolista tende a praticar preços mais elevados já que o "poder de monopólio" por ele detido o permite fixar preços acima do nível de custos, obtendo lucros acima do competitivo ou "normal". Por isso, comparando a 


\section{Oportuno citar Nélson de Andrade Branco ${ }^{52}$ :}

(...) um acordo, um ajuste, uma convenção de empresas independentes, que conservam, apesar desse acordo, sua independência administrativa e financeira (...) o cartel tem como precípuo objetivo eliminar ou diminuir a concorrência e conseguir o monopólio em determinado setor de atividade econômica. Os empresários agrupados em cartel têm por finalidade obter condições mais vantajosas para os partícipes, seja na aquisição da matéria-prima, seja na conquista dos mercados consumidores, operando-se, de forma a eliminação do processo normal de concorrência (apud FORGIONI, 2005, p. 326).

\section{O Banco Mundial e a OCDE apresentam a seguinte definição para os cartéis:}

Agreements among competitors, often referred to as 'horizontal' agreements, are implicit or explicit agreements that restrict competitors' ability to act independently. The term encompasses a broad range of conduct, from joint ventures, joint advertising or marketing, or trade association activities, to price-fixing and bid rigging (OCDE, 2003, p. 61).

Nesse sentido, confira-se o disposto no XXVIII Relatório Anual sobre a Política de Concorrência da Comunidade Europeia, de 1998:

Na tipologia das restrições de concorrência, os acordos e as práticas concertadas entre empresas sob a forma de acordos secretos constituem indubitavelmente o tipo mais prejudicial. Estas práticas concertadas agrupam muitas vezes um número importante de operadores econômicos de um determinado sector de atividades e têm por consequência uma incidência muito acentuada sobre os mercados em causa. Além disso, estes acordos dizem quase sempre respeito aos preços e conseguem deste modo falsear o jogo da concorrência de forma muito eficaz.

situação de monopólio com a de concorrência, verifica-se a perda de bem-estar do consumidor e a maior transferência de renda para o produtor em detrimento do consumidor.

52 BRANCO, Nelson de Andrade; BARRETO, Celso de Albuquerque. Repressão ao abuso do poder econômico: lei antitruste. São Paulo: Atlas, 1964. 
A jurisprudência do CADE (BRASIL, 2003) ${ }^{53}$ tem proposto a diferenciação entre o cartel enquanto clássicos (ou integrais) e difusos. Define enquanto cartéis clássicos aqueles acordos secretos entre competidores, com alguma forma de institucionalidade, com o objetivo de fixar preços e condições de venda, dividir consumidores, definir nível de produção ou impedir a entrada de novas empresas no mercado. Explica que este tipo de cartel opera através de um mecanismo de coordenação institucionalizado, podendo ser reuniões periódicas, manuais de operação, princípios de comportamento, etc. Isto é, sua ação não decorre de uma situação eventual de coordenação, mas da construção de mecanismos permanentes para alcançar seus objetivos. Por outro lado, jurisprudência nacional estabelece que o cartel difuso é um ato de coordenação da ação entre empresas com objetivo similar ao do cartel clássico, mas de caráter eventual e não institucionalizado. Esse grupo ocorre quando um grupo de empresas decide reunir-se para coordenar um aumento de preço, muitas vezes em função de um evento externo que as afetou simultaneamente. Isto é, tal ação pode ser considerada eventual e não decorreu de uma organização permanente para coordenar as ações das empresas envolvidas.

Consequentemente, ao elevar os preços ao comprador e/ou reduzindo os preços dos vendedores, impacta diretamente o bem-estar econômico à medida que transfere a renda da sociedade para os integrantes do cartel, por meio artificial de competição. Em conclusão, pode-se que os cartéis são acordos entre agentes econômicos, que atuam no mesmo mercado, destinados a anular a concorrência.

\footnotetext{
${ }^{53}$ Investigação que levou as autoridades à conclusão de que havia um cartel entre as empresas de pedra britada.
} 


\subsection{Tratamento normativo dado à espécie no Brasil \& sistema de análise de condutas da} Lei n. 12.529/11

A Constituição Federal que data de 1988 (BRASIL, 1988) estabelece em seu artigo $173 \S 4^{\circ}$ que "A lei reprimirá o abuso do poder econômico que vise à dominação dos mercados, à eliminação da concorrência e ao aumento arbitrário dos lucros". Com efeito, veio ao encontro de tal dispositivo a Lei de n. 8.884/94 - nesta parte integralmente acolhida pelo Diploma Brasileiro Antitruste - quando caracterizou o cartel - sem, no entanto usar essa denominação - em seu art. 36 (antigo 20) caput e incisos de I a IV combinado com o $\S 3^{\circ}$ incisos I e II (antigo art. 21 caput e incisos de I a III e VIII) ${ }^{54}$.

O conceito jurídico expresso na legislação relevante em vigor propõe, assim, que a partir da conjugação do artigo $36 \mathrm{e}$ incisos com o $\S 3^{\circ}$ do mesmo artigo, cabe ao intérprete analisar o enquadramento do caso concreto ora em investigação, isto porque o legislador não traz a definição expressa do que venha ser cartel. Nesse sentido, Fonseca (2001, p. 21) afirma a lacuna da conceituação de cartel na norma:

O Tratado de Roma e a Lei Brasileira adotam uma postura de enumeração exemplificativa, sem pretender qualquer definição dos "tipos legais". Aqui também a

\footnotetext{
54 “Constituem infração da ordem econômica, independentemente de culpa, os atos sob qualquer forma manifestados, que tenham por objeto ou possam produzir os seguintes efeitos, ainda que não sejam alcançados: I - limitar, falsear ou de qualquer forma prejudicar a livre concorrência ou a livre iniciativa; II - dominar mercado relevante de bens ou serviços; III - aumentar arbitrariamente os lucros; IV - exercer de forma abusiva posição dominante. $\S 3^{\circ}$ As seguintes condutas, além de outras, na medida em que configurem hipótese prevista no caput deste artigo e seus incisos, caracterizam infração da ordem econômica: I - acordar, combinar, manipular ou ajustar com concorrente, sob qualquer forma: a) os preços de bens ou serviços ofertados individualmente; b) a produção ou a comercialização de uma quantidade restrita ou limitada de bens ou a prestação de um número, volume ou frequência restrita ou limitada de serviços; c) a divisão de partes ou segmentos de um mercado atual ou potencial de bens ou serviços, mediante, dentre outros, a distribuição de clientes, fornecedores, regiões ou períodos $^{54}$; d) preços, condições, vantagens ou abstenção em licitação pública; II - promover, obter ou influenciar a adoção de conduta comercial uniforme ou concertada entre concorrentes".
} 
identificação e definição das condutas ficam a cargo dos órgãos legalmente competentes para decidir sobre questões afetas à concorrência, sempre levando em conta os princípios ordenadores.

Na tentativa de preencher tal lacuna foi editada a Resolução do CADE de n. 20/99 ${ }^{55}$ que tenta orientar a definição o cartel e apresenta maiores elementos característicos de tal infração. Destacam-se os vocábulos inseridos na legislação que indicam que o cartel se refere ao acordo entre concorrentes para a restrição da concorrência. Ainda que a livre concorrência possa ser atingida por acordos existentes entre agentes econômicos que estejam em níveis diferentes da cadeia produtiva, como produtores e distribuidores, tais acordos caracterizam a colusão vertical $^{56}$, que não é objeto do presente estudo.

A referida Resolução também indicou a análise de tais condutas - e de todas as outras - pressupõe a regra da razão, ou seja, a impossibilidade de se haver uma prática condenável per se e ainda instituiu como pressuposto da configuração do ilícito administrativo a existência de poder de mercado ${ }^{57}$.

55 "Cartéis: acordos explícitos ou tácitos entre concorrentes do mesmo mercado, envolvendo parte substancial do mercado relevante, em torno de itens como preços, quotas de produção e distribuição e divisão territorial, na tentativa de aumentar preços e lucros conjuntamente para níveis mais próximos dos de monopólio". (BRASIL, 1999, grifo nosso).

${ }^{56}$ Para Forgioni (1998, p. 324) “(...) os acordos verticais disciplinam relações entre agentes econômicos que desenvolvem suas atividades em mercados relevantes diversos, muitas vezes complementares. (...) lida-se com uma imaginária linha vertical que nos conduz, através da extração da matéria-prima, das várias fases da produção e comercialização, até o consumidor final do produto. Assim, à guisa de exemplo, um acordo celebrado entre uma empresa fabricante do produto e outra distribuidora é um típico acordo vertical."

${ }^{57}$ Em geral, tais práticas (cartéis) pressupõem a existência ou a busca de poder de mercado sobre o mercado relevante. Em diferentes graus, algumas podem também gerar benefícios em termos de bem-estar ao mercado ("eficiências econômicas"), recomendando a aplicação do "princípio da razoabilidade".

O principal pressuposto, a ser verificado preliminarmente pela análise, é que condutas prejudiciais à concorrência, e não apenas a concorrente(s), em geral, requerem a pré-existência, a alavancagem de um mercado para outro ou a busca de posição dominante no mercado relevante por parte de quem a pratica.

Aplicando-se o princípio da razoabilidade, esses requisitos constituem condições necessárias, mas não suficientes, para considerar uma conduta prejudicial à concorrência. 
Assim, para a caracterização do cartel, o intérprete deve realizar uma leitura conjunta dos artigos supracitados. Na lição do professor Calixto Salomão (2007, p. 68), a função do art. 21 (atual artigo 36) na sistemática da Lei n 8.884/84 é "fornecer aos agentes econômicos suficiente segurança jurídica através da declaração expressa de um certo número ainda que não fechado - de infrações puníveis".

De acordo com o próprio texto da lei, somente haverá a caracterização de cartel e, portanto, uma infração econômica, se houver aptidão à produção de algum dos efeitos enumerados nos incisos do caput do art. 36 da Lei quais sejam: "I - limitar, falsear ou de qualquer forma prejudicar a livre concorrência e a livre iniciativa; II - dominar mercado relevante de bens ou serviços; III - aumentar arbitrariamente os lucros; IV - exercer de forma abusiva posição dominante".

O vocábulo "independente de culpa" do caput do art. 36 é digno de esclarecimento uma vez que sua inserção implica na desnecessidade de provas de espectro subjetivo (existência de dolo ou de culpa) para a caracterização da conduta enquanto infração da ordem econômica.

Tudo isso implica dizer que a sistemática do Diploma Brasileiro Antitruste prevê a caracterização do ilícito concorrencial cartel - assim, como de qualquer outra conduta somente quanto presente qualquer elemento do binômio objeto anticoncorrencial/possibilidade de realização do efeito anticoncorrencial, traduzido pela expressão legislativa do caput "que tenham por objeto ou possam produzir os seguintes efeitos (art. 36), ainda que não sejam alcançados". E em qualquer elemento do binômio há estar presente a figura do "abuso poder econômico" uma vez que o artigo $173 \S 4^{\circ}$ da Carta Magna à ela se refere de forma taxativa enquanto única conduta a ser reprimida. A "condição necessária" da existência de "posição dominante" para a caracterização da infração veio a ser de forma clara consolidada na Resolução n. 20/99 do CADE em seu Anexo II.

Por isso se diz que no campo das condutas, o Diploma Brasileiro Antitruste adotou o sistema de caracterização do ilícito pelo objeto ou efeito, o qual já havia sido inaugurado pela Lei n. 8.884/94. Nos termos da Lei, incorre em ilícito concorrencial, aquele(s) agente(s) econômico(s) que praticam uma conduta descrita no art. $\S 3^{\circ}$ do artigo 36 ou qualquer outra - 
uma vez que o rol não é exaustivo e meramente exemplificativo - que possa efetiva ou potencialmente produzir os resultados enunciados no art. 36.

Ora, também como se observa da redação do caput do art. 36, que para a configuração do ilícito basta a potencialidade de uma conduta gerar algum dos efeitos nele descritos. Em outras palavras, a lei não exige que o efeito tenha sido alcançado para a caracterização da conduta e consequente aplicação da pena. Ou seja, são condições suficientes para a identificação conduta ilícita “(...) a existência de evidências, seja da intencionalidade do ato em produzir os efeitos dos incisos, seja da capacidade do ato de produzir aqueles efeito" $(\text { BRASIL, 2004) })^{58}$.

Neste sentido também são as palavras do professor Calixto Salomão Filho (2001, p. 119):

(...) a lei brasileira não impõe a produção concreta de efeitos para caracterizar a ilicitude. Basta a potencialidade de sua ocorrência. Além disso, os efeitos (ou sua potencialidade) não são um critério único, mas apenas uma alternativa à existência da intenção (objetivo) de eliminar os concorrentes do mercado.

Estudaremos a seguir a interpretação do CADE quanto a sistemática da lei para o tratamento dos cartéis, restringindo-nos a uma limitação relevante do tema, à interpretação dos elementos essenciais para a caracterização dos cartéis internacionais.

\subsection{Tratamento jurisprudencial: a aplicação da regra per se na sistemática da regra da razão}

\footnotetext{
58 Voto do Conselheiro Relator Fernando de Oliveira Marques no Processo Administrativo de n. 08012.003208/99-85.
} 
O extrato do voto abaixo transcrito se deu por ocasião do julgamento e posterior condenação do primeiro, e até o momento o único, caso de formação de cartel internacional. Tratou-se da aplicação de multa ${ }^{59}$ às empresas F. Hoffman - La Roche Ltda., Basf Aktiengesellschaft e Aventis Animal Nutrition pela conduta colusiva no mercado de vitaminas $^{6061}$ com reflexos de seus efeitos no Brasil $^{62}$ durante o período de 1990 a 1999.

Na legislação da defesa da concorrência na maioria dos países não é necessário provar os prejuízos de um cartel aos consumidores para condená-lo. Basta-se provar a sua existência para presumir-se seus efeitos nocivos. Nessa linha documento da $\mathrm{OECD}^{63}$ sobre cartéis clássicos afirma que "Não é, no entanto, fácil quantificar esses efeitos. Isto requer uma comparação da situação atual do mercado sob o cartel com a que existiria em um hipotético mercado competitivo. Autoridades da defesa da competição normalmente não tentam realizar esse cálculo, porque estes são igualmente difíceis e desnecessários na maioria das legislações. (BRASIL, 2007)

Como se vê, a partir da obtenção de elementos indiciários da existência de um cartel $^{64}$, o entendimento prevalecente do Conselho é que já teria se alcançado um "quantum

59 A representada F. Hoffman - La Roche Ltd foi multada no valor de R\$ 12.112.558,32; a Basf Aktiengesellschaft em R \$ 4.726.362,37, a Aventis Animal Nutrition em R \$ 847.125,19. Foi vencido o saudoso Conselheiro Schuartz, que votou pelo arquivamento do Processo Administrativo.

${ }^{60}$ Especificamente das vitaminas A, B2, B5, C, E e Betacaroteno, porém, as autoridades optaram por definir o mercado material enquanto o de "vitaminas em geral" conforme indicado pelo relatório do Conselheiro Relator, às fls. 3.200 e seguintes dos autos. Muito embora a autora acredite ser extremamente saudável uma avaliação do acerto ou não desta definição, esta avaliação não faz parte do recorte a ser investigado por esta pesquisa.

${ }^{61}$ A conduta em questão, nos termos do despacho de instauração das Averiguações Preliminares emitido pelo Secretário de Direito Econômico, às fls. 1.088 dos referidos autos, refere-se às práticas de fixação de preços entre concorrentes, à influência exercida com vistas à adoção de conduta comercial concertada, à regulação de mercados de bens, estabelecendo acordos para limitar sua produção e imposição de preços excessivos, nos termos dos incisos I a IV do art. 20 c/c incisos I, II, X, XXIV do art. 21, na forma do art. 32 e seguintes da Lei 8.884/94.

${ }^{62} \mathrm{O}$ entendimento prevalecente das autoridades competentes foi que o setor de vitaminas no período de atuação do cartel internacional era praticamente abastecido por importações, já que no território brasileiro não se encontravam plantas de síntese de vitaminas, à exceção de uma pequena unidade da Basf localizada no Brasil para a produção de B5 - patotenato de cálcio e somente para uso veterinário, além de algumas outras poucas plantas de transformação das formas oleosas das vitaminas A e D, importadas de seus centros produtores, em forma de pó, exclusivas para uso veterinário.

${ }^{63}$ Cita o documento da OCDE (2003, p. 8) intitulado Hard Core Cartels - Recent Progress and Challenges Ahead.

64 "Admite-se em nosso direito punitivo, inclusive no processo administrativo sancionador para apurar a infração à ordem econômica, a prova indiciária (art. 239 do CPP), não cabendo exigir que a infração à ordem econômica 
probatório" que inclusive prescindiria de estudos econométricos tidos enquanto "desnecessários, controversos e irrelevantes" suficientemente capazes de fundamentar o jus puniendi do Estado em matéria concorrencial. Consignou não haver a exigência de padrão de prova específico para as infrações à ordem econômica, e que o "quantum probatório" não precisaria ser quantificado ou estabelecido uma vez que impera no Brasil o princípio do livre convencimento motivado consagrado no art. 157 do Código do Processo Penal "segundo o qual o juiz forma sua convicção pela livre apreciação da prova, no ficando adstrito a critérios valorativos e apriorísticos e é livre sua escolha, aceitação e valorização ${ }^{65}$ ".

\subsection{Características: oportunidade e conveniência para cartelizar}

Segundo a literatura econômica (HOVENKAMP, 1999, p. 144), é possível identificar algumas características ou condições inerentes a um determinado mercado que propiciam entre seus agentes a formação de um cartel e facilitam a sustentação da colusão. É o que chamamos de "conveniência e oportunidade para a cartelização", ou seja, as condições facilitadoras para a formação e sustentação de um cartel.

A “conveniência" para cartelizar se traduz nas circunstâncias estruturais de determinado mercado que segundo alguns modelos econômicos de cartéis (CONNOR, 2001a ${ }^{66}$; DICK, $1998^{67}$; STIGLER, $1964^{68}$, apud CONNOR, 2002) induziriam as empresas

somente possa ser caracterizada ante a existência de prova direta". Cf .Voto do Conselheiro Relator do Processo, Ricardo Villas Boa Cueva (BRASIL, 2007).

${ }^{65}$ Cita Mirabete (2004, p. 477).

${ }^{66}$ CONNOR, John M. Global Price Fixing: Our Customers are the Enemy. Boston: Kluwer, 2001.

${ }^{67}$ DICK, Andrew R. Cartels. In: EATWELL, John (ed.). The New Palgrave Dictionary of Law and Economics. Londres: Macmillan, 1998.

${ }^{68}$ STIGLER, George J. A Theory of Oligopoly. Journal of Political Economy, n. 72, 1964, pp. 44-61. 
concorrentes ao exercício coordenado de condutas comerciais. Entre elas estão (i) a homogeneidade dos produtos e a concorrência unidimensional em preço, uma vez que diminuem o lucro na ausência de monopólio; (ii) presença de barreiras significativas à entrada $^{69}$ e/ou importação pois que aumentam o lucro sob a operação do cartel e (iii) a fragmentação dos compradores, pois que diminui o poder de barganha do lado da compra e, consequentemente, aumenta o lucro dos participantes do cartel.

A chamada "oportunidade de cartelização" se refere à possibilidade de se sustentar o conluio tacitamente. Ante a necessária informalidade de tais acordos ${ }^{70}$, o cartel depende de uma série de condições garantidoras para seu sucesso e para a sua sustentabilidade. Pode-se enumerar as condições relevantes para a sustentação de um cartel $^{71}$, considerando a latente ameaça de traição $^{72}$ (instabilidade). São elas: número reduzido de firmas e homogeneidade de produtos $^{73}$, porte econômico similar entre elas, homogeneidade de produtos e concorrência unidimensional em preço, homogeneidade entre os custos das firmas, compras pequenas e frequentes, observabilidade de demanda, estabilidade da demanda, ausência de inovação tanto de produtos como de processos de produção, e contato multimercado.

\footnotetext{
${ }^{69} \mathrm{Na}$ acepção pioneira de Joe Bain, as barreiras à entrada dizem respeito às condições que permitiriam que as firmas estabelecidas em um determinado mercado relevante pudessem perceber lucros extraordinários sem induzir a entrada de novos concorrentes. CF. Bain (1956).

${ }^{70}$ Uma vez que nos parece ter ficado em um passado bastante longínquo a época em que cartéis eram formalmente constituídos e registrados em cartório pelos seus integrantes.

${ }^{71}$ Uma boa referência para as condições que facilitam a sustentabilidade dos cartéis é desenvolvida por SALOP (1986).

${ }^{72}$ Ao estabelecer quantidades menores que as que prevaleceriam sem o acordo, cria-se, entre os membros do cartel, um ambiente tentador para trair o acordo e produzir mais e/ou a um preço menor do que combinado, e assim, lucrar mais que os outros. Cf. Connor (1996).

${ }^{73}$ Segundo Connor (1996) - "Without small numbers of member-sellers and reasonably standardized products, the transactions costs of forming and maintaining a group consensus would become too high relative to the anticipated increase in profits".
} 


\subsection{A esfera criminal}

Como se viu, o cartel constitui uma conduta anticoncorrencial tipificada no artigo 36 caput e incisos combinados com seu $\S 3^{\circ}$ e incisos da Lei n. 12.529/11. Nos termos do Diploma Antitruste, trata-se de ilícito de natureza administrativa.

O cartel também constitui uma conduta criminal tipificada no art. $4^{\circ}$ e seus incisos I, II, itens "a", "b" e "c" da Lei n. 8.137/90 (BRASIL, 1990) que define crimes contra a ordem tributária, econômica e contra as relações de consumo, e dá outras providências ${ }^{74}$. Porém, impende esclarecer que o ilícito antitruste não se confunde com o ilícito criminal e, assim, a responsabilização da esfera administrativa dele decorrente tampouco se confunde com a responsabilização penal. Nessa esteira, vale lembrar lição de Hely Lopes Meirelles (1992, p. 414), para quem:

A punição interna, autônoma que é, pode ser aplicada ao servidor antes mesmo do julgamento judicial do mesmo fato. E assim é porque, como já vimos, o ilícito administrativo independe do ilícito penal. A absolvição criminal só afastará o ato punitivo se ficar provada, na ação penal, a inexistência do fato, ou que o acusado foi seu autor.

Há, como se pode ver, a incidência de duas leis sobre um mesmo fato, qual seja a infração à ordem econômica por meio da cartelização. Essa interceptação de diplomas legais é

\footnotetext{
74 “Art. $4^{\circ}$ Constitui crime contra a ordem econômica: I - abusar do poder econômico, dominando o mercado ou eliminando, total ou parcialmente, a concorrência mediante qualquer forma de ajuste ou acordo de empresas; II formar acordo, convênio, ajuste ou aliança entre ofertantes, visando: a) à fixação artificial de preços ou quantidades vendidas ou produzidas; b) ao controle regionalizado do mercado por empresa ou grupo de empresas; c) ao controle, em detrimento da concorrência, de rede de distribuição ou de fornecedores. (Redação dada pela Lei $\mathrm{n}^{\circ} 12.529$, de 2011)”.
} 
de grande valia para a análise da questão da cooperação penal internacional para o combate dos cartéis transfronteiriços.

\subsection{Paralelismo consciente: a não configuração da infração}

O paralelismo consciente ou conscious parallelism doctrine é a situação em que determinados agentes econômicos adotam uma mesma política comercial, mas tal prática advém da racionalidade econômica individual de cada concorrente ${ }^{75}$. Trata-se, de um comportamento paralelo - sem evidências da existência de acordo - cuja racionalidade esteja condicionada à adoção de conduta semelhante pelos demais concorrentes. Apesar da uniformização da conduta dos agentes, sua justificativa econômica - fundamentada pela interdependência entre os agentes em uma situação de oligopólio - embasa a descaracterização de um cartel e, portanto, de ilicitude.

É de se notar que caso a interdependência oligopolística fosse caracterizada como um acordo para fins concorrenciais, então, estará demonstrado o ilícito na conduta. Contudo, a prova econômica da presença de um acordo entre concorrentes exige que o paralelismo consciente esteja associado a outros fatores, isto é, o paralelismo consciente mais fator plus.

\footnotetext{
75 "Consciously parallel. Antitrust. Of, relating to, or characterizing the conduct of a party who has knowledge of a competitor's action (such as raising prices) and who makes an independent decision to take the same action". GARNER (1999, p. 244).
} 
Para a configuração do paralelismo, há que se observar se, plano do comportamento estratégico dos agentes, há características estruturais do mercado que lhes são impostas como parâmetros nos processos decisórios individuais. Se observadas tais características, não há que se falar em punição desse padrão de conduta. Em vários ordenamentos jurídicos tais como Estados Unidos, União Européia e Brasil, o paralelismo consciente é entendido como comportamento lícito. 


\section{Capítulo II - Da incidência da jurisdição extraterritorial no Direito Antitruste}

\section{Seção I - Princípios de Direito Internacional necessários para a compreensão do instituto}

\section{Nota introdutória sobre a concepção de jurisdição extraterritorial}

Há muito pouco, se algum, questionamento sobre a competência dos Estados em reprimir práticas contrárias aos seus ordenamentos jurídicos de defesa da concorrência ocorridas em seu próprio território ou que sobre ele produzam danos. Ora, cabe ao Estado, através de seus poderes legalmente constituídos, a função de dizer o Direito do qual decorrem os conceitos de jurisdição e competência (NUSDEO, A., 2001 apud SANTOS, 2007, p.109).

O Estado (do latim status, que significa estar firme) corresponde a "todas as sociedades políticas que, com autoridade superior, fixaram as regras de convivência de seus membros" (DALLARI, 1995, p. 43), tendo, em geral, sido apontadas três características fundamentais, ou elementos essenciais, para sua identificação, sendo duas delas de ordem material (território e povo) e uma de origem formal (descrita normalmente como soberania ${ }^{76}$ ).

\footnotetext{
${ }^{76}$ A "Soberania, do latim super omnia ou de superanus ou supremitas (caráter dos domínios que não dependem senão de Deus), significa, vulgarmente, o poder incontestável do Estado, acima do qual nenhum outro poder se encontra" (PAUPERIO, 1958, p. 23). Jean Jacques Rousseau sugere um novo conceito de soberania, que reside
} 
Lembra Kelsen (1998) que a doutrina tradicional distingue três elementos do Estado: seu território, seu povo e seu poder, admitindo-se que seja da essência do Estado ocupar certo território delimitado. O território do Estado é, assim, aquele espaço dentro do qual os seus órgãos estão autorizados pelo Direito Internacional a executar a ordem jurídica nacional (KELSEN, 1998, p. 299-300), sendo a esfera territorial de validade da ordem jurídica chamada Estado. É o Estado submetendo à sua jurisdição todos os fatos que lhe são pertinentes.

A cada Estado cabe o poder de legislar e aplicar o Direito emanado de seu arcabouço jurídico a fatos que ocorrem nos limites de seu território ou afetem seus mercados. Assim, cabe ao Estado, através de seus poderes legalmente constituídos a função de dizer o Direito, do qual decorrem conceitos de jurisdição e competência ${ }^{77}$. Com efeito, o termo "jurisdição ${ }^{78 ", ~ d e s c r e v e ~ a ~ a u t o r i d a d e ~ e s t a t a l ~ d e ~ a t u a r ~ s o b r e ~ i n t e r e s s e s ~ e s s e n c i a l m e n t e ~ l e g a i s ~}$ (HENKIN et al., 1993, p. 1046), referindo-se à autoridade do Estado de dizer o Direito, seja por meio da produção de suas normas, de sua aplicação ou de sua execução. Logo, existem três tipos distintos de jurisdição: (i) normativa/prescritiva (criação de norma ou jurisdiction to precribe); (ii) judicial/adjudicativa (aplicação de norma ou juridiction to adjudicate/ to apply) e a (iii) executiva (execução de norma ou juridiction to enforce).

no povo e se confunde com a vontade social, superando o modelo formulado por Hobbes, que indicava a reunião dos indivíduos primitivos para transferir seus poderes para um terceiro ente, o Estado. No contrato social, Rousseau identifica que os indivíduos pactuam entre si, transformando-se em cidadãos soberanos e súditos de si mesmos (ROUSSEAU, 1996, p. 125). O que interessa para o presente trabalho é, naturalmente, o conceito de soberania ora compreendido pelo prisma internacional. A Carta da Organização das Nações Unidas, em seu artigo $1^{\circ}$, estabelece enquanto alguns dos objetivos das Nações Unidas o de "desenvolver relações de amizade entre as nações baseadas no respeito do princípio da igualdade de direitos e da autodeterminação dos povos" (grifo nosso). Mais adiante, em seu artigo $2^{\circ}$, defende que a Organização e os seus membros agirão de acordo com alguns princípios, entre eles o princípio da igualdade soberana de todos os seus membros.

${ }^{77}$ Vale conferir a abordagem das competências normativa e judiciária dos Estados em artigo de Almeida (2001, p.67-87).

${ }^{78}$ Em Direito Processual, o termo remete à interpretação literal, "dizer, ditar o direito". 
Constituindo-se em elemento integrante da soberania, mas com ela não se confundindo, a jurisdição é, então, geralmente exercida nos limites territoriais do país. No âmbito nacional, a jurisdição é exercida de forma livre em relação aos assuntos exclusivos do Estado. No âmbito internacional, o termo "jurisdição extraterritorial" - entendido pela doutrina como controverso e impreciso (ROSENTHAL; KNIGHTON, 1982, p. 8) ${ }^{79}$ - é adotado neste trabalho seguindo a doutrina majoritariamente aceita de Jean Combacau e Serge Sur (1999, p. 347), segundo a qual o exercício da jurisdição extraterritorial se traduz na expressão estatal de aplicar suas normas para reger condutas, determinar situações ou levar em consideração fatos exteriores a seu território ${ }^{80}$. Concerne, assim, a consideração, por parte das autoridades nacionais, de elementos situados fora dos limites geográficos do Estado (STERN, 1987, p. 158).

Também sobre a imprecisão do termo "extraterritorialidade", alerta Martinez (2005, p. 88) que o mesmo "pode levar a erro, dado que a jurisdição extraterritorial pode manifestar-se independentemente da natureza do elemento de conexão adotado (territorial ou não)".

É certo também que a aplicação da jurisdição extraterritorial pode ter sua legitimidade justificada por não haver alternativa que permita submeter as empresas ao enforcement necessário, de modo a evitar as infrações concorrenciais praticadas ao redor do mundo.

\footnotetext{
${ }^{79}$ No mesmo sentido, Cf. NEREP (1983, p. 465-467 e p. 481). Ora, uma vez que a jurisdição territorial não pode ser exercida pelas autoridades de um Estado em outro sem que haja expresso consentimento, alguns autores criticam sua caracterização como "extraterritorial". Vale apontar que a jurisdição, uma vez exercida dentro das fronteiras nacionais de um Estado, afeta pessoas, atos e propriedades localizados em outros, sendo, por esse motivo, denominada "extraterritorial".

${ }^{80}$ Nas palavras desses autores, "[u]ne norme st extraterritoriale, au moment ou elle opére, elle pretend régir des conduits, statuer sur situations, ou prende en consideration dês faits, extérieurs au territoire".
} 
No que tange ao escopo das atividades comerciais das empresas, é certo que as fronteiras territoriais dos Estados estão sendo cada vez mais transpostas à medida que as empresas expandem seus negócios. Por um lado, se como resultado da globalização as atividades das empresas estão "sem-fronteiras", no que tange à aplicação dos regimes jurídicos, no entanto, de acordo com o Direito Internacional, os Estados exercem sobre seu território e sobre seus nacionais o princípio exclusivo de sua jurisdição.

Os negócios são regulados pelas leis nacionais de cada Estado ou por acordos internacionais assinados pelos Estados. Assim, a pergunta que cabe responder é: como moderar as empresas com atividades "sem-fronteiras" nos regimes jurídicos nacionais? Na esfera do comércio internacional, as medidas de cada Estado estão limitadas aos acordos internacionais e, em particular, ao regime GATT/OMC. Porém, falta à esfera da defesa da concorrência um regime internacional universal.

Dessa forma, a problemática reside em se definir, de forma razoável, quais são os vínculos mais adequados a justificar a aplicação extraterritorial da legislação antitruste de determinado país, e que, por sua coerência, levariam à aceitação natural da aplicabilidade de lei alienígena pelo Estado em que a norma deva ser cumprida.

Assim, enquanto os efeitos de um cartel internacional não respeitam qualquer limite de fronteiras, a extensão da aplicabilidade das leis nacionais é mais restrita. Se a soberania e a independência estatais constituem os princípios sobre os quais se desenvolve a liberdade do Estado no desempenho de sua jurisdição normativa em face de outros Estados, como exercê-la sem afrontar a soberania da outra nação? Em quais situações se legitima o exercício jurisdicional? Quais princípios gerais e específicos foram estabelecidos pelo Direito Internacional que limitam tal exercício? Essas são algumas das perguntas que a presente seção se propõe a responder. 


\subsection{Fundamentos utilizados pelos Estados para justificar a extraterritorialidade de seu exercício jurisdicional}

Consequências da igualdade entre os Estados no âmbito do Direito Internacional são (1) que os Estados têm poder jurisdicional para atuar na consecução dos interesses comuns da sociedade internacional ${ }^{81}$ e (2) a possibilidade de admissão de efeitos extraterritoriais às normas nacionais, alcançando pessoas, recursos ou eventos fora de seus territórios em razão de um vinculo fático do evento com o território, como a nacionalidade dos agentes, o objeto do negócio ou da relação jurídica, ou a valores que direta ou indiretamente afetem o Estado em seus domínios territoriais (MAGALHÃES, 1999, p. 661).

O poder de cada Estado (1) é exercido nacional e internacionalmente em prol de seu interesse e de valores comuns e, naturalmente, encontra limites de modo a evitar conflitos com a ordem internacional vigente. Para tanto, segundo a doutrina internacionalista, a legitimidade deve demonstrar que os interesses internos defendidos pelo Estado coincidem com os valores caros à sociedade internacional ${ }^{82}$. É exatamente neste sentido o artigo 27 da Convenção de Viena sobre o direito dos tratados, de 1969: “: uma parte não pode invocar as disposições de seu direito interno como justificativa para o descumprimento de um tratado”.

\footnotetext{
81 Adolfo Miaja de La Muela adota a diferenciação entre conceitos de comunidade e sociedade internacional, elaborada por Poch e Gutiérrez de Caviedes. A sociedade internacional surge da relação estabelecida artificialmente por seus membros através de contratos e é conduzida primordialmente com base em valores jurídicos, enquanto a comunidade internacional possui vínculos naturais que independem de qualquer ação estatal nesse sentido, se caracterizando pela predominância dos valores éticos sobre os jurídicos e da origem de seus princípios no direito natural (LA MUELA, 1974, p. 12-14)

${ }^{82}$ Esse mecanismo é denominado de "persuasão", sendo empregado para dirimir conflitos entre os Estados (MAGALHÃES, 1999, p.53-54)
} 
Também nesse sentido são as fontes do Direito Internacional, ${ }^{83}$ que podem informar uma eventual limitação da jurisdição estatal. A Corte Internacional de Justiça já afirmou inclusive que a jurisdição, em princípio pertencente ao Estado, está limitada pelas regras do Direito Internacional ${ }^{84}$.

Por outro lado, verifica-se (2) a possibilidade de admissão de efeitos extraterritoriais às normas nacionais não só pela delimitação de competência interna dos Estados, mas por critérios que admitam a competência destes para analisar fatos ocorridos fora de seus territórios e também para o cumprimento de suas decisões além de suas fronteiras. É o que se depreende do artigo $2^{\circ}$ da Carta das Nações Unidas ${ }^{85}$, de 1945.

O problema é que o Direito Internacional, que deve reconhecer os limites da jurisdição extraterritorial estabelecidos por seus princípios, ainda não se manifestou de forma inequívoca sobre o assunto $^{86}$. Conciliar os interesses estatais nacionais com os da sociedade internacional apresenta-se, então, como a grande problemática a ser enfrentada.

83 “Art. 38: 1. A Corte, cuja função é decidir de acordo com o direito internacional as controvérsias que lhe forem submetidas, aplicará: a) as convenções internacionais, quer gerais, quer especiais, que estabeleçam regras expressamente reconhecidas pelos Estados litigantes; b) o costume internacional, como prova de um prática geral aceita com sendo o direito; c) os princípios gerais do direito, reconhecidos pelas nações civilizadas; d) sob ressalva da disposição do art. 59, as definições judiciárias e a doutrina dos juristas mais qualificados da diferentes nações, como meio auxiliar para a determinação das regras de direito" (ONU, TRIBUNAL INTERNACIONAL DE JUSTIÇA, 1945).

84 "jurisdiction which, in principle, belongs solely to the State, is limited by rules of international law", do caso Nationality Decrees in Tunis and Morocco (1921) (apud MANN, F., 1964, p. 17)

${ }^{85}$ Artigo 2: A Organização e seus Membros, para a realização dos propósitos mencionados no Artigo 1, agirão de acordo com os seguintes princípios:

Nenhuma disposição da presente Carta autorizará as Nações Unidas a intervir em assuntos que dependam essencialmente da jurisdição interna de qualquer Estado, ou obrigará os membros a submeterem tais assuntos a uma solução, nos termos da presente Carta; este princípio, porém, não prejudicará a aplicação das medidas coercitivas constantes do capítulo VII.

${ }^{86}$ Em Direito Penal, contudo, pode-se dizer que se alcançou algum tipo de consenso. Segundo o artigo 7 do Código Penal Brasileiro, incisos I e II, os princípios informadores da jurisdição extraterritorial do Direito Penal podem ser assim agrupados segundo alguns doutrinadores, como Nucci, Delmanto e Jesus (2008, p. 114): (1) Defesa ou Proteção: na qual se leva em conta a nacionalidade brasileira do bem jurídico lesado pelo delito, (2) Justiça Universal ou Cosmopolita: na qual se tem em vista punir os crimes de alcance internacional, (3) 
Especificamente para o Direito Antitruste, considerando a recente e intensa atividade econômica internacional que ocasionou o surgimento dos cartéis internacionais, a aplicação extraterritorial das leis antitruste é, por vezes, fonte de conflitos entre as jurisdições interessadas. A participação de indivíduos e empresas na ordem econômica de dois ou mais Estados, fenômeno pujante no contexto de globalização, enseja situações de conflitos entre as diversas jurisdições afetadas (MEESEN, 1996).

Segundo a lição de Jacob Dolinger (1996, p. 257), as regras ou elementos de conexão são “as normas estatuídas pelo Direito Internacional que indicam o direito aplicável às diversas situações jurídicas conectadas a mais de um sistema legal”. Assim, o elemento de conexão tem utilidade na medida em que busca solucionar conflitos entre mais de uma legislação, a princípio aplicáveis a uma situação concreta.

Assim, há que se questionar sobre os critérios de fixação da jurisdição extraterritorial, ou seja, os fundamentos jurídicos que a tornam legal e legítima quanto à possibilidade de sua aplicação para a legislação da defesa da concorrência. Com este propósito, critérios embasados nos princípios da territorialidade, do comportamento e dos efeitos, da nacionalidade, da segurança pública, da universalidade e da personalidade passiva, e solidificados pelos usos e costumes internacionais (MAGALHÃES, 1999, p.662-663) serão a seguir abordados.

\subsubsection{Princípio da nacionalidade}

Nacionalidade ou Personalidade: na qual se leva em conta a nacionalidade brasileira do agente do delito, (4) Representação ou Bandeira: na qual se tem em consideração a bandeira brasileira da embarcação ou da aeronave privada, situada em território estrangeiro. 
O princípio da nacionalidade, também denominado "princípio da personalidade" e reconhecido pelo Direito Internacional para o exercício da jurisdição extraterritorial, permite que o Estado exerça competência para aplicar sua própria lei aos seus nacionais ${ }^{87}$ mesmo que estejam fora de suas fronteiras. Ora, é legítimo que os Estados exerçam jurisdição sobre seus nacionais, onde quer que eles se encontrem, sendo fundamental para sua aplicação o ingresso de tais agentes no território de seu Estado. Com base neste princípio, as regras estabelecidas pelo direito interno devem ser aplicadas antes daquelas alienígenas. Tal princípio, contudo, tem menor importância no âmbito do Direito Antitruste do que o princípio dos efeitos internos ou do impacto territorial a ser estudado no item 1.1.6., o qual tem por base o princípio geral de que cada Estado é soberano para organizar e preservar sua ordem econômica nacional, a que se sujeitam todos aqueles que dela participem, independentemente de sua nacionalidade ou domicílio. Poder-se-ia fazer uma ressalva e pensar na utilização do princípio da nacionalidade para fixar a jurisdição extraterritorial às situações em que atos de uma empresa brasileira, ainda que praticados no exterior, estariam sujeitos à legislação brasileira. Contudo, a atribuição de nacionalidade às pessoas jurídicas ${ }^{88}$ normalmente acaba sendo regulado pelo direito interno, sendo um tema pouco explorado. Nesse sentido:

Assim, não obstante a pessoa jurídica tenha a nacionalidade formal de um Estado, podem seus dirigentes, ou, de qualquer forma, detentores de seu controle, ficar sujeitos à legislação de outro. É o que ocorre, sob esse aspecto, com a legislação antitruste dos Estados Unidos, aplicada com caráter extraterritorial, quando alcança atos praticados por nacionais no exterior mesmo que ao abrigo das leis locais. Essa prática faz aflorar um conflito de competência e de qualificações entre os Estados, pois interfere com pessoas jurídicas de outras nacionalidades que estão adstritas a

\footnotetext{
${ }^{87}$ Segundo Pontes de Miranda (1935, p. 37), "nacionalidade é o vínculo jurídico-político de Direito Público interno, que faz da pessoa um dos elementos componentes da dimensão pessoal do Estado".

${ }^{88}$ Para maior elucidação sobre o assunto, ver a análise da nacionalidade das pessoas jurídicas na perspectiva do direito comparado, colocada por Rodas (1995).
} 
seguir os parâmetros das leis nacionais a que estão sujeitas (MAGALHÃES, 1999, p. 662-663).

Com efeito, é de grande complexidade a determinação da nacionalidade da pessoa jurídica, uma vez que são vários e muitas vezes divergentes ${ }^{89}$ entre si os critérios internos utilizados pelos Estados, além do fato do Direito Internacional ter se manifestado poucas vezes sobre o tema.

\subsubsection{Princípio da proteção da segurança nacional}

Também conhecido como "princípio da real ou da defesa" leva em consideração a nacionalidade do bem jurídico lesado, independentemente da nacionalidade do sujeito ativo ou do local da prática do crime. Ora, o Estado tem competência para aplicar sua legislação quando sua integridade e segurança pública estão em perigo. Assim, tal princípio legitima a jurisdição do Estado para processar ou julgar os fatos que ocorrem no exterior caso o ato atente contra as suas instituições, sua organização ou sua credibilidade, tal como a emissão de moeda estrangeira, moeda falsa ou a emissão de selos falsos no exterior.

Segundo Hungria (1955, p. 144): "Este princípio resulta da necessidade de se acautelarem, os Estados, contra crimes que se praticam, no estrangeiro, contra seus interesses vitais".

\footnotetext{
${ }^{89}$ O professor José Carlos de Magalhães (1974, p. 97-124) traz uma importante análise sobre os critérios, à luz da aceitação do Direito Internacional.
} 


\subsubsection{Princípio da universalidade}

Em consonância com o princípio da universalidade ou cosmopolita, o Estado pode punir os crimes contra os quais deve lutar em nível mundial ou que internacionalmente ele tenha assumido, por tratado ou convenção, a obrigação de punir, sendo irrelevante o lugar da realização da conduta, a nacionalidade dos sujeitos ou do bem jurídico atingido. Por exemplo, em casos de crimes de guerra, genocídios, redução da liberdade e tráfico de pessoas, o Estado pode aplicar as suas normas a tais fatos uma vez que estes possuem uma configuração universal e condenada universalmente.

\section{Segundo Mestieri (1990, p. 117):}

O fundamento desta teoria é ser o crime um mal universal, e por isso todos os Estados têm interesse em coibir a sua prática e proteger os bens jurídicos da lesão provocada pela infração penal.

Dessa forma, o Brasil, por meio de tratados ou convenções (art. $7 .^{\circ}$, II, $a$, do Código Penal) se obrigou a reprimir o tráfico internacional de drogas, a falsificação de moedas, o tráfico de mulheres, a criminalidade altamente organizada e os crimes em matéria de meio ambiente. É o que se denomina de Direito Internacional convencional.

O cartel é uma infração às leis de defesa da concorrência, mas também se configura enquanto crime, sendo certo que tem a consideração da grande maioria das jurisdições ao redor do mundo de que tal prática, por tão perversamente danosa à economia, merece ser severamente combatida. 


\subsubsection{Princípio da personalidade passiva}

O princípio da personalidade passiva permite a um Estado a extensão internacional de sua jurisdição nos casos em que seus nacionais estejam envolvidos, no pólo passivo da demanda. Magalhães (1999, p. 664) alerta que a determinação da jurisdição com base neste principio é bastante controvertida e o argumento para justificar tal princípio não tem sido aceito nos sistemas jurídicos dos países da Common Law.

Decidido em 1927, o caso Lótus, um dos mais importantes sobre o assunto, decorre de um acidente marítimo em alto mar - em águas internacionais - entre um navio francês e outro turco. Na ocasião, França e Turquia concordaram em submeter à Corte Permanente Internacional de Justiça a discussão sobre afixação de competência para julgamento de crime praticado em alto mar, uma vez que a colisão resultou na morte de tripulantes turcos ${ }^{90}$.

O Presidente da Corte Internacional afirmou que o Direito Internacional obriga os Estados a agir conforme as restrições estabelecidas nos tratados e convenções internacionais ou naquelas aceitas geralmente nos usos e costumes. Contudo, inexistindo restrição expressa ou implícita em tais fontes de direito, os Estados podem agir livremente. Em suas palavras:

\footnotetext{
${ }^{90}$ Em 2 de agosto de 1926, o navio turco Boz-Kourt colidiu com a embarcação francesa Lótus, que transportava correspondências. O Boz-Kourt partiu-se em dois e afundou, o que resultou na morte de oito marinheiros turcos. O Lótus levou os sobreviventes até Constantinopla. O tenente M. Demons, cidadão francês, era o responsável pela navegação no Lótus e Hassan Bey era o capitão do Boz-Kourt, que foi salvo pelos franceses após a colisão. Em 3 de agosto de 1926, as autoridades policiais da Turquia iniciaram o inquérito, com o objetivo de apurar as responsabilidades pelo ocorrido; em 5 de agosto intimaram o tenente Demons para prestar depoimento. Em seguida, os turcos detiveram o tenente Demons, sem prévio aviso, no Consulado-Geral da França. Hassan Bey também foi preso. O promotor de Istambul requereu a prisão preventiva dos dois, Demons e Bey, indiciando-os pela prática de homicídio culposo. O tenente Demons foi condenado a 80 dias de prisão e ao pagamento de uma multa de 22 libras turcas. Hassan Bey foi condenado a uma pena um pouco mais severa.
} 
International law governs relations between independent States. The rules of law binding upon States therefore emanate from their own free will as expressed in conventions or by usages generally accepted as expressing principles of law and established in order to regulate the relations between these co-existing independent communities or with a view to the achievement of common aims. Restrictions upon the independence of States cannot therefore be presumed. Now the first and foremost restriction imposed by international law upon a State is that - failing the existence of a permissive rule to the contrary - it may not exercise its power in any form in the territory of another State. In this sense jurisdiction is certainly territorial; it cannot be exercised by a State outside its territory except by virtue of a permissive rule derived from international custom or from a convention ${ }^{91}$ (S.S. LOTUS (Fr. v. Turk.), 1927, p.27).

\section{Sobre a tese francesa, de que a bandeira deveria definir a competência em questão}

\section{e não a nacionalidade da vítima, lê-se na decisão vencedora:}

The second argument put forward by the French Government is the principle that the State whose flag is flown has exclusive jurisdiction over everything which occurs on board a merchant ship on the high seas. It is certainly true that - apart from certain special cases which are defined by international law - vessels on the high seas are subject to no authority except that of the State whose flag they fly. In virtue of the principle of the freedom of the seas, that is to say, the absence of any territorial sovereignty upon the high seas, no State may exercise any kind of jurisdiction over foreign vessels upon them. Thus, if a war vessel, happening to be at the spot where a collision occurs between a vessel flying its flag and a foreign vessel, were to send on board the latter an officer to make investigations or to take evidence, such an act would undoubtedly be contrary to international law. But it by no means follows that a State can never in its own territory exercise jurisdiction over acts which have occurred on board a foreign ship on the high seas. A corollary of the principle of the freedom of the seas is that a ship on the high seas is assimilated to the territory of the State the flag of which it flies, for, just as in its own territory, that State exercises its authority, upon it, and no other State may do so. All that can be said is that by virtue of the principle of the freedom of the seas, a ship is placed in the same position as

${ }^{91}$ Tradução livre: “O Direito Internacional governa as relações entre Estados independentes. O direito que vincula aos Estados decorre consequentemente das próprias vontades dos Estados, tais como expressas nos tratados ou nos usos geralmente aceitos como indicativos de princípios de direito, fixados com o objetivo de regular as relações entre as comunidades independentes coexistentes ou com vista à obtenção de objetivos comuns. Restrições impostas aos Estados não podem ser presumidas. A primeira e mais importante restrição imposta pelo direito internacional a um Estado é que, na existência de regra permissiva contrária, o Estado não pode exercer seu poder, de nenhuma forma, no território de outro Estado. Nesse sentido, a jurisdição é certamente territorial; não pode ser exercida por um Estado em território que não seja seu, exceto por força de regra permissiva que decorra de um costume ou tratado internacional." 
national territory but there is nothing to support the claim according to which the rights of the State under whose flag the vessel sails may go farther than the rights which it exercises within its territory properly so called ${ }^{92}$ (S.S. LOTUS (Fr. v. Turk.), 1927, p. 68).

Em suma, prevaleceu a ótica de que:

Far from laying down a general prohibition to the effect that States may not extend the application of their laws and the jurisdiction of their courts to persons, property and acts outside their territory, it leaves them in this respect a wide measure of discretion, which is only limited in certain cases by prohibitive rules; as regards other cases, every State remains free to adopt the principles which it regards as best and most suitable ${ }^{93}$ (S.S. LOTUS (Fr. v. Turk.), 1927, p. 68).

\section{Assim, decidiu a Corte Permanente Internacional de Justiça em favor da Turquia, afirmando - com fundamentos que não ficaram perfeitamente claros - inexistir regra de Direito Internacional que proibisse o Estado ao qual pertencia o navio, onde os efeitos do}

${ }^{92}$ Tradução livre: "O segundo argumento levantado pelo governo francês decorre do princípio de que o Estado sob cuja bandeira se navegue possua jurisdição exclusiva para julgar tudo o que ocorra no aludido navio mercante em alto mar. É certamente verdade que - além de certos casos especiais definidos pelo Direito Internacional navios em alto mar não são sujeitos a nenhuma autoridade exceto à do Estado da bandeira sob a qual navegam. Como resultado do princípio da liberdade dos mares, isto é, da ausência de qualquer soberania territorial em alto mar, nenhum Estado pode exercer jurisdição sobre navios estrangeiros. Assim, se uma embarcação de guerra, que por algum acaso esteja no local no qual se tenha uma colisão entre embarcação de bandeira igual a sua e embarcação estrangeira, e enviar para essa última um oficial para investigar, ou para colher provas, ter-se-á indubitavelmente um ato contrário ao Direito Internacional. Mas isso não significa que um Estado não possa jamais exercer jurisdição no território próprio, em relação a fatos que ocorreram a bordo de navio estrangeiro em alto mar. Um corolário do princípio da liberdade dos mares é que um navio em alto mar seja assimilado ao território do Estado sob cuja bandeira navega, porque, apenas em seu próprio território é que um Estado exerce autoridade, sobre o próprio território, nenhum outro Estado podendo fazê-lo. Tudo o que pode ser dito é que em virtude do princípio da liberdade dos mares, um navio é colocado na mesma posição de território nacional, mas não há nada que justifique a argumentação de que os direitos de um Estado sob cuja bandeira navega uma embarcação possam ir além dos direitos que possa exercer em território próprio".

${ }^{93}$ Tradução livre: "Longe de se afirmar uma proibição geral, no sentido de que os Estados não podem estender a aplicação de suas leis e sua jurisdição a seus tribunais e pessoas, propriedades e atos fora de seus territórios, ele ( o Direito Internacional) lhes confere, a esse respeito, uma ampla discricionariedade, que é somente limitada em certos casos por regras proibitivas; em relação a outros casos, todo Estado permanece livre para adotar os princípios que ele considera como melhores e mais adequados". 
delito se manifestassem, de exercer jurisdição, com base na ficção de que o delito fosse cometido em seu próprio território. Para Cretella Neto (2008, p. 275):

O efeito sobre o navio turco foi equiparado a um efeito sobre o território da Turquia. É preciso cautela nessa análise, contudo, pois, em primeiro lugar, o acidente ocorrera em alto-mar e, em segundo lugar, nem navios nem embaixadas são partes do "território nacional", pelo que essa abordagem artificial meramente obscurece as questões jurídicas.

\subsubsection{Princípio da territorialidade}

O princípio da territorialidade é o mais importante e o menos controverso já que é fundado no conceito da soberania do Estado em exercer sua jurisdição sobre seu próprio território. Todo Estado goza de independência em relação aos demais e de supremacia em relação aos seus nacionais e estrangeiros em seu território. A lei de um país terá aplicação aos fatos ocorridos dentro de seu território sendo certo que o Estado deve exercer sua jurisdição sobre as pessoas que se encontrem em seu território. Com efeito, é o mais básico e persuasivo princípio que deriva do exercício dos Estados em poder regular fatos e atividades em seu próprio território. Por exemplo, o Estado pode aplicar suas leis ambientais às atividades comerciais desempenhadas dentro de suas fronteiras. Pelo princípio da territorialidade, o Estado tem também competência para regular os comportamentos cujos efeitos são sentidos em seu território, circunstância que, segundo Magalhães (1999, p. 664), representa um alargamento do próprio conceito de território por considerar produzido nele o evento ocorrido parcialmente no exterior.

Em razão do sujeito e do local em que se verificam os eventos, costuma-se segregar o princípio da territorialidade na vertente subjetiva e na objetiva. Enquanto a subjetiva (local da atividade), permite que o Estado manifeste sua jurisdição sobre os atos iniciados em seu território, mas finalizados fora dele, a vertente objetiva (local do resultado) 
permite ao Estado manifestar sua jurisdição sobre os atos iniciados fora de seu território, mas finalizados dentro dele.

Segundo Magalhães (1999, p. 664):

O princípio da territorialidade objetiva estabelecer uma relação de causa e efeito no evento ocorrido parcialmente no exterior e parcialmente dentro do Estado, o que confere aos Estados envolvidos, em igualdade de condições, competência para regular o evento, bem assim, seus participantes. A justificativa aqui é a ocorrência parcial do fato no território e, por via de consequência, do impacto social que o mesmo causou. O Estado mais afetado pela ocorrência tem, preponderantemente, maior interesse em submetê-la à sua competência territorial. E é a maior ou menor intensidade do impacto no território dos Estados envolvidos que serve de elemento definidor das competências.

De acordo com o critério subjetivista, o Estado possui competência judiciária sobre participantes de eventos iniciados no Estado, mas consumados no exterior, desde que estes adentrem o seu território. De acordo com o princípio subjetivo, o início, a preparação, a realização do ato, cujos efeitos se produzam fora, fundamenta a competência. Pelo princípio objetivo, é o local da consumação, onde os efeitos danosos se fazem sentir, que justifica a asserção da competência.

A propósito das limitações do princípio da territorialidade da jurisdição estatal em caso de conflito de jurisdições, uma vez que há situações em que infrações transnacionais afetem simultaneamente duas ou mais jurisdições ocasionando no fenômeno chamado “jurisdição concorrente de Estados”, observa Mann (1973, p. 50-51):

But the simplicity of Huber-Storyan teaching is deceptive. The question, for instance, where a crime or tort is committed is subject to so much doubt that no certain answer can be suggested in any but the clearest cases; nor has territorial test led to much certainty in the field of trade practices or taxation. Finally, from a point of view of the progressive evolution of international law, it would be no doubt desirable if the principle of exclusivity would come to be accepted for the purpose of jurisdiction, if, in other words, by common consent jurisdiction in respect of a given set of acts were exercised by one State only. Such development cannot begin while the doctrine of jurisdiction is embedded in the procrustean law of territoriality. It is, 
however, likely that to be promoted by a doctrine which bases jurisdiction upon closeness connection ${ }^{94}$.

\subsubsection{Princípio do efeito interno ou impacto territorial ou Teoria dos Efeitos ("Effects} Doctrine")

A teoria dos efeitos é aquela que adota enquanto elemento de conexão o efeito interno ou impacto territorial por parte do ordenamento jurídico, normalmente no plano do Direito Econômico, do Estado afetado por práticas comerciais transfronteiriças. A incidência da lei do Estado é verificada não em razão da nacionalidade ou do domicílio dos partícipes, mas sim em razão daquele território no qual os efeitos da prática são produzidos.

Segundo Forgioni (2005, p. 503-505),

No âmbito do Direito Antitruste, este é o mais comum dos elementos de conexão, sendo adotado pelo tratado da Comunidade Europeia e pelas legislações norteamericanas e brasileira.

94 Tradução livre: “A simplicidade dos ensinamentos Huber-Storyan é enganosa. A questão, por exemplo, da situação em que o crime ou o delito é cometido está sujeita a tanta dúvida que nenhuma resposta tem sugerido nas áreas de comércio internacional ou de tributos que o teste da territorialidade leva à certeza de sua aplicação correta senão nas situações mais evidentes. Finalmente, do ponto de vista da evolução do Direito Internacional, é sem dúvida desejável que o princípio da exclusividade seja aceito para efeitos de jurisdição, se, em outras palavras, por comum consentimento, a jurisdição em relação a determinado conjunto de atos for exercida por um único Estado. Tal evolução não pode começar enquanto a doutrina da jurisdição for incorporada na lei de Procrustes de territorialidade. É, no entanto, provável que, para ser promovido por uma doutrina que baseie a jurisdição mediante uma maior de proximidade". 
A teoria dos efeitos é dita aplicável por aqueles que a defendem em situações em que os efeitos do crime são produzidos no território do Estado afetado. Assim, o Estado possui jurisdição sobre os estrangeiros e acontecimentos estrangeiros que produzam efeitos em seu território, afastando-se do conceito do princípio da territorialidade objetiva na medida em que atribui a jurisdição extraterritorial não ao Estado em que foi consumado o crime, mas sim àquele no qual se fizeram sentir seus resultados ou efeitos.

Segundo Magalhães (1999, p. 73), esta teoria parte da premissa que "os efeitos do ato danoso carregam consigo seus autores”. Também para o mesmo autor:

\begin{abstract}
O ponto central dessa doutrina é o de que, embora o evento ocorra no exterior, em área internacional ou dentro de outro Estado, se tal evento produz importante consequência no território do Estado, este pode legitimamente aplicar quaisquer meios para submeter a seu controle, vale dizer, a sua competência legislativa e judiciária, os autores do evento, a fim de proteger seus interesses ameaçados. Isto é, o requisito de que parte do evento ocorra efetiva e fisicamente dentro do território, como propugnado pelo princípio da territorialidade subjetiva ou objetiva, é substituído pelo requisito dos resultados ou das consequências do fato dentro do território. (MAGALHÃES, 1999, p. 666)
\end{abstract}

Tal teoria é resultado da construção jurisprudencial estadunidense que passou a interpretar extensivamente o princípio da territorialidade objetiva enfrentando diversas críticas ante a indeterminação e subjetividade do termo "efeitos". Outros autores a criticam, sobretudo, por tal doutrina não corresponder ao catálogo tradicional de elementos de conexão do Direito Penal Internacional ${ }^{95}$. Geralmente, os Estados que aceitam, em princípio, a teoria dos efeitos adotam como requisito de aplicação outros elementos que mais se aproximem do princípio da territorialidade e que lhe assegurem a efetividade, tal como inicialmente proposto pelos Estados Unidos da América. Dentre eles, destacam-se aqueles elementos com os quais haja certa proximidade entre "efeitos" e a ordem jurídica interna, exigindo que tais efeitos sejam

95 Cf., em lugar de muitos, MANN (1964, p. 1-161; p. 100-108, e as referências na nota 206), SEIDLHOHENVELDERN (1971, p. 55 e ss, com referências). Veja-se também a crítica mais recente de COPPEL (1993, p. 73-90). 


\title{
"diretos e substanciais", "atuais" e "previsíveis" (ANTITRUST DIVISION, U.S. DEPARTMENT OF JUSTICE, 1995).
}

\author{
Nas palavras de Sullivan (1977, p. 187), \\ todo e qualquer contrato, combinação ou acordo, mesmo aqueles que envolvam \\ apenas empresas estrangeiras, pode violar a Lei Sherman caso afete a concorrência \\ no mercado externo americano ou o próprio comércio exterior americano. Ao \\ reconhecimento de ofensa à lei, não é necessário demonstrar uma redução no fluxo \\ da mercancia exterior, mas, tão somente, uma violação que afete substancialmente tal \\ comércio.
}

Marc-André Renold (1991, p. 148) aponta que muitos Estados adotam esse enfoque para aplicação de sua própria legislação antitruste:

É fácil constatar que, usando exatamente a liberdade que lhes confere o direito internacional público, os Estados frequentemente adotaram o critério dos efeitos para delimitar o âmbito de aplicação de sua legislação. A prática das autoridades nacionais se baseia amplamente no critério dos efeitos. 


\section{Seção II - A consagração do instituto pelo Direito Antitruste Brasileiro}

\section{A jurisdição extraterritorial da Lei $\mathbf{n}^{\circ} \mathbf{1 2 . 5 2 9 / 1 1}$}

A teoria dos efeitos foi inaugurada no Brasil ${ }^{96}$ em 1994 por meio da Lei de $n^{\circ}$ $8.884^{97}$, revogada pela Lei de $n^{\circ} 12.529 / 2011$, seguindo uma tendência internacional já adotada por diversas jurisdições, como Austrália, Canadá, Estados Unidos da América, Nova Zelândia e União Europeia. A Lei de n ${ }^{\circ}$ 8.884/ 1994, ao revogar as Leis de n ${ }^{\circ}$ 4.137, de 10 de setembro de 1962, de $\mathrm{n}^{\circ} 8.002$, de 14 de março de 1990 e de $\mathrm{n}^{\circ} 8.158$, de 8 de janeiro de 1991, dispondo sobre a prevenção e a repressão às infrações contra a ordem econômica, conferiu caráter extraterritorial às suas disposições, nos termos do artigo $2^{\circ 98}$. A Lei de $\mathrm{n}^{\circ} 12.529 / 2011$,

${ }^{96}$ O Brasil e a Argentina, que introduziu essa doutrina em sua legislação antitruste em 1999 através da Lei de ${ }^{\circ}$ 25.156, são os únicos países da América Latina e do Caribe que a aceitam em suas legislações. As leis antitruste vigentes no hemisfério estão disponíveis em: www.sice.oas.org.

${ }^{97}$ Antes da entrada em vigor da Lei de $n^{\circ}$ 8.884/94, não havia dispositivo legal expresso autorizando a aplicação extraterritorial do direito da concorrência brasileiro, sendo o único elemento de conexão relacionado no art. $2^{\circ}$, inciso I, da Lei $\mathrm{n}^{\circ} 4.137$ referia-se apenas aos "mercados nacionais". "Art. $2^{\circ}$ : Consideram-se formas de abuso do poder econômico: I - Dominar os mercados nacionais ou eliminar total ou parcialmente a concorrência por meio de: a) ajuste ou acordo entre empresas, ou entre pessoas vinculadas a tais empresas ou interessadas no objeto de suas atividades; b) aquisição de acervos de empresas ou de cotas, ações, títulos ou direitos; c) coalisão, incorporação, fusão, integração ou qualquer outra forma de concentração de empresas; d) concentração de ações; títulos, cotas ou direitos em poder de uma ou mais empresas ou de uma ou mais pessoas físicas; e) acumulações de direção, administração ou gerência de mais de uma empresa; f) cessação parcial ou total das atividades de empresa promovida por ato próprio ou de terceiros; g) criação de dificuldades à constituição, ao funcionamento ou ao desenvolvimento de empresa; (...)".

98 “Art. $2^{\circ}$ : Aplica-se esta lei, sem prejuízo de convenções e tratados de que seja signatário o Brasil, às práticas cometidas no todo ou em parte no território nacional ou que nele produzam ou possam produzir efeitos. $\S 1$ Reputa-se domiciliada no território nacional a empresa estrangeira que opere ou tenha no Brasil filial, agência, sucursal, escritório, estabelecimento, agente ou representante. § 2 A empresa estrangeira será notificada e intimada de todos os atos processuais previstos nesta Lei, independentemente de procuração ou de disposição contratual ou estatutária, na pessoa do agente ou representante ou pessoa responsável por sua filial, agência, sucursal, estabelecimento ou escritório instalado no Brasil". 
que entrou em vigor em 29 de maio de 2012, repete ipsis litteris, também em seu artigo $2^{\circ}$ caput e $\S 1$ o mesmo texto da lei anterior ${ }^{99}$.

\section{Análise do artigo $2^{\circ}$ caput e $\S \S \&$ dos critérios de para aplicação extraterritorial da Lei Antitruste Brasileira}

\subsection{Princípio da territorialidade e dos efeitos}

É bastante claro o texto do artigo $2^{\circ}$ da Lei de $n^{\circ} 12.529 / 2011$ no sentido de adotar, expressamente, além do critério da territorialidade ("práticas cometidas no todo ou em parte no território no Território Nacional”), o critério dos efeitos (“ou que nele produzam ou possam produzir efeitos”). Note-se também que o Brasil terá jurisdição para apreciar a prática restritiva ainda que seus efeitos não se tenham concretizado em território brasileiro, mas exista a possibilidade de que tal fato venha a ocorrer. Ou seja, a competência brasileira estender-se-á ainda a que os efeitos sejam considerados como "potenciais".

Assim, o Direito Concorrencial Brasileiro considera enquanto elemento de conexão e critério determinador da aplicação do direito pátrio os efeitos (efetivos ou potenciais) em seu território. O Brasil aplica suas leis aos efeitos (efetivos ou potenciais) ou ao resultado, verificados em seu território, da prática ocorrida no exterior.

\footnotetext{
${ }^{99}$ Em relação ao $\S 2^{\circ}$, a antiga redação apresentava conteúdo ligeiramente diferente, mas que trazia o mesmo princípio em geral: "A empresa estrangeira será notificada e intimada de todos os atos processuais, independentemente de procuração ou de disposição contratual ou estatutária, na pessoa do responsável por sua filial, agência, sucursal, estabelecimento ou escritório instalado no Brasil”.
} 
Da leitura do dispositivo acima, manteve o legislador o requisito da vinculação do fato ou da prática ao território, adotando a teoria dos efeitos do fato no território, como extensão do princípio da territorialidade, objetivo também consagrado pelo artigo $6^{\circ 100}$ do Código Penal.

Nota-se que a redação do caput do artigo $2^{\circ}$ da Lei de $n^{\circ} 12.529 / 2011$, utilizada para afirmar a doutrina dos efeitos (“às práticas cometidas no todo ou em parte no território nacional ou que nele produzam ou possam produzir efeitos"), prescinde de maiores elementos de definição ou restrição para o termo "efeitos". Segundo Corrêa (2002, p. 156):

A terminologia usada pelo legislador para tratar da teoria do impacto territorial (...), sem qualitativos para o vocábulo "efeitos" (v.g. "substanciais", "diretos", "relevantes", "previsíveis" etc.) indica a adoção intencional (política legislativa) de uma formulação ampliada ou postura extensiva na determinação da jurisdição antitruste nacional.

O espectro de maior alcance é encontrado na redação do caput do artigo $2^{\circ}$ da Lei Antitruste Brasileira ou "essa formulação ampliada da jurisdição extraterritorial"

acaba por facilitar, na prática, a aplicação do Direito Antitruste positivo, já que a autoridade administrativa não estará constrangida a comprovar a intensidade, a proximidade ou a previsibilidade dos efeitos sobre a ordem econômica interna de modo a fazer atuar o comando normativo Corrêa (2002, p. 156).

\footnotetext{
${ }^{100}$ Considera-se praticado o crime no lugar em que ocorreu a ação ou omissão, no todo ou em parte, bem como onde se produziu ou deveria produzir-se o resultado. Vale observar que não se fez a distinção se tal disposição se aplica a crimes cometidos no território nacional ou no estrangeiro.
} 
Para Franceschinni (2003, p. 440), o Diploma Antitruste Brasileiro aplica o princípio da ubiquidade, ou seja, considera-se competente para punir infrações cometidas no exterior que produzam ou possam produzir efeitos no território nacional. Tal autor entende, dessa forma, que:

Os critérios de definição de competência internacional da jurisdição brasileira estão estabelecidos por meio do critério do "locus delictus" e não pelo domicílio ou residência do acusado (CORRÊA, 2002, p. 35).

\subsection{Princípio da nacionalidade}

Nota-se também que a aplicação extraterritorial do Direito Antitruste brasileiro pelo critério da territorialidade e pelo local de verificação dos efeitos prescinde de análise da nacionalidade dos agentes. Nesse sentido, a nacionalidade dos agentes não é tratada de especial forma para a definição da jurisdição extraterritorial brasileira no Direito Antitruste, não importando a nacionalidade dos envolvidos para efeitos da aplicação da legislação, nas hipóteses de violação.

\subsection{Análise da jurisdição pessoal}

Uma vez analisadas as classificações materiais da jurisdição extraterritorial da Lei Antitruste Brasileira, há que se estudar os aspectos pessoais da competência da autoridade de defesa brasileira em julgar a empresa estrangeira que praticou a conduta anticoncorrencial, cujos efeitos repercutiram em território nacional. 
$\mathrm{O} \S 1^{\circ}$ do artigo $2^{\circ}$ ora em comento estabelece que se reputa domiciliada no território nacional a empresa estrangeira que opere ou que tenha no Brasil filial, agência, sucursal, escritório, estabelecimento, agente ou representante. O $\S 2^{\circ}$ do referido artigo determina que a empresa estrangeira será notificada e intimada de todos os atos processuais previstos nesta lei, independentemente de procuração ou de disposição contratual ou estatutária, na pessoa do agente, representante ou pessoa responsável por sua filial, agência, sucursal, estabelecimento ou escritório instalado no Brasil.

Para Leopoldino da Fonseca (2001, p. 88-89), a redação do dispositivo em comento não adota expressamente a jurisdição in personam e afirma que "o legislador não se preocupa aqui com a aplicação subjetiva da lei, não importam os sujeitos. O que interessa é o ato e lugar do ato".

Para Silva (2004, p. 359-360), o exercício da jurisdição pessoal é justificado pelo fundamento da competência territorial, sendo que:

o Código de Processo Civil prefere estabelecer a competência internacional das autoridades brasileiras sob este prisma tão-somente. Assim, embora pela leitura dos artigos 88 e 89 do CPC seja possível verificar quando a competência internacional tem como alicerce a relação entre território e a matéria, e quando ela se fundamenta na vinculação existente entre território e a pessoa. O liame é estabelecido sempre com o território e não há um tratamento específico para os temas da jurisdição pessoal em apartado.

Vale dizer também que, para fins de fundamentar as normas de competência internacional e de citação estabelecidas no artigo $2^{\circ}$ ora em estudo, conforme a Exposição de Motivos da Medida Provisória 2.055-1, de 2000 (BRASIL, 2000, p. 22.724-22.725), que deu origem à Lei 10.149/2000, o legislador esclareceu expressamente que se valeu das disposições 
do artigo $88^{101}$ do Código de Processo Civil e dos artigos 12 , VII ${ }^{102}$, e $216^{103}$ do Código de Processo Civil, sobre citação de empresas estrangeiras.

Assim, de acordo com ótica adotada pela legislação pátria, a competência internacional das autoridades brasileiras é fundamentada na competência territorial.

\section{Sujeitos do Diploma Antitruste Brasileiro}

Faz-se necessário um esclarecimento sobre aquelas pessoas, físicas e jurídicas, que estão sujeitas às autoridades brasileiras de defesa da concorrência. Os artigos $31^{104}, 32^{105} \mathrm{e}$ $33^{106}$ do Diploma Antitruste Brasileiro são os dispositivos estabelecem os sujeitos que se submetem à jurisdição antitruste brasileira.

101 “Art. 88. É competente a autoridade judiciária brasileira quando: I - o réu, qualquer que seja a sua nacionalidade, estiver domiciliado no Brasil; II - no Brasil tiver de ser cumprida a obrigação; III - a ação se originar de fato ocorrido ou de ato praticado no Brasil. Parágrafo único. Para o fim do disposto no inciso I, reputa-se domiciliada no Brasil a pessoa jurídica estrangeira que aqui tiver agência, filial ou sucursal".

102 “Art. 12. Serão representados em juízo, ativa e passivamente: (...) VII - a pessoa jurídica estrangeira, pelo gerente, representante ou administrador de sua filial, agência ou sucursal aberta ou instalada no Brasil (Art. 88, parágrafo único (...)".

103 "Art. 216. A citação efetuar-se-á em qualquer lugar em que se encontre o réu”.

${ }^{104}$ Art. 31. Esta Lei aplica-se às pessoas físicas ou jurídicas de direito público ou privado, bem como a quaisquer associações de entidades ou pessoas, constituídas de fato ou de direito, ainda que temporariamente, com ou sem personalidade jurídica, mesmo que exerçam atividade sob regime de monopólio legal. (BRASIL, 2011).

105 Art. 32. As diversas formas de infração da ordem econômica implicam a responsabilidade da empresa e a responsabilidade individual de seus dirigentes ou administradores, solidariamente. (BRASIL, 2011).

${ }^{106}$ Art. 33. Serão solidariamente responsáveis as empresas ou entidades integrantes de grupo econômico, de fato ou de direito, quando pelo menos uma delas praticar infração à ordem econômica. (BRASIL, 2011). 
Percebe-se que tais artigos trazem o critério da subjetividade, sendo o Diploma Antitruste Brasileiro aplicado às pessoas físicas e jurídicas por ela descritas. Como se percebe da leitura dos dispositivos acima transcritos, o legislador procurou uma redação legislativa ampla de modo a estender a lei a todas as situações em que suas possíveis violações sejam vislumbradas. Os ilícitos descritos pela lei podem assim ser praticados por quaisquer pessoas físicas ou jurídicas, sejam elas de Direito Público ou Privado que tenham se constituído segundo as exigências legais ou cuja existência seja meramente de fato. É de se notar que inexiste qualquer menção quanto à nacionalidade de tais pessoas, corroborando, assim, o entendimento esposado nos itens 2.1, 2.2 e 2.3 acima de que o princípio da nacionalidade tem irrelevante importância em vista da consagração, pelo Direito Antitruste Brasileiro, da teoria dos efeitos. Assim o Brasil é soberano para preservar sua ordem econômica nacional, sujeitando todos aqueles que dela participem, independentemente de sua nacionalidade ou domicílio.

\section{Estudo de Casos}

Sobre a aplicação da teoria dos efeitos nos termos do artigo $2^{\circ}$ caput do Diploma Antitruste Brasileiro, que submete à aplicação desta os atos que produzam ou possam produzir efeitos no território nacional, a pouca jurisprudência em casos de cartéis internacionais tem afirmado seu caráter extraterritorial nas circunstâncias em que há afetação do mercado brasileiro. Nesse sentido, no caso do cartel internacional de vitaminas, o único em que o CADE se manifestou sobre o tema, o Conselheiro Relator Ricardo Villas Bôas Cueva, cujo voto prevaleceu, afirmou:

é induvidosa a aplicabilidade das normas brasileiras de defesa da concorrência, ainda que nenhum ato tenha sido praticado em território nacional e mesmo que nenhum 
efeito tenha de fato se produzido, bastando que se prove a potencialidade dos danos internamente dos atos praticados fora do Brasil ${ }^{107}$.

Considerou, então, o voto vencedor como critério para aplicar a legislação antitruste brasileira no caso, ou seja, para que a jurisdição brasileira incidisse sobre a prática anticompetitiva em questão, o local da verificação dos efeitos, como expressamente admitido pelo dispositivo legal. Pela leitura do trecho do voto, vale notar também que o Conselheiro Relator reiterou o dispositivo em questão sobre a aplicação da jurisdição brasileira enquanto competente para apreciar práticas anticompetitivas, ainda que seus efeitos não tenham sido concretizados, mas que exista sua "potencialidade". Assim, previu estender, conforme the permite a legislação, a competência brasileira àqueles efeitos, ainda que considerados potenciais.

O voto-vogal do então Conselheiro Paulo Furquim de Azevedo traz relevantes considerações sobre a matéria ora em estudo:

Uma jurisdição é afetada por cartel - e, portanto, este deve ser objeto de condenação nesta jurisdição - se sua área de abrangência inclui no todo ou em parte o objeto do cartel (i.e. o mercado afetado pela conduta concertada). É absolutamente o local onde o acordo é desenhado (onde ocorreram reuniões, acompanhamento de condutas, etc.), se em São Paulo, São João da Boa Vista, Ilha de Comandatuba, Paris, Madagascar ou o espaço sideral. Relevante é o espaço abrangido pelo objeto do acordo. (...). O local onde o cartel é celebrado é irrelevante em uma análise de mérito. Importa saber qual foi o espaço abrangido pelo acordo entre empresas (grifos nossos). ${ }^{108}$.

${ }^{107}$ Conforme voto do Conselheiro Relator no bojo do Processo Administrativo de 08012.004599/1999-18 (BRASIL, 2007, p. 7).

${ }^{108}$ Conforme voto-vista do Conselheiro Paulo Furquim de Azevedo no bojo do Processo Administrativo de 08012.004599/1999-18 (FURQUIM, 2007, p. 7). 
O acórdão do caso foi igualmente expresso ao reconhecer a aplicação da teoria dos efeitos ao caso:

Aplicabilidade da lei brasileira a atos praticados no exterior que produzam ou possam produzir efeitos no território nacional: princípio dos efeitos (art. $2^{\circ}$ da Lei ${ }^{\circ}$ 8.884).

No bojo do Processo Administrativo de n. 08012.004897/2000-23 (BRASIL, ANO), caso conhecido como "cartel internacional das lisinas", o parecer da SDE, à fl. 1942 e 1944, respectivamente, dos autos do processo, também afirmou:

Tendo ocorrido um ato no exterior que tenha a potencialidade de produzir efeitos no Brasil, seus responsáveis devem ser processados perante a lei brasileira.

Tendo em vista a potencialidade de gerar efeitos no Brasil, a partir dos atos ocorridos fora do território nacional, justifica-se a atuação da SDE.

Também no acima mencionado caso sobre o alegado cartel internacional de lisinas, nota-se que a SDE determinou enquanto Representadas do polo passivo as subsidiárias ou escritórios de representação no Brasil das empresas envolvidas no cartel internacional e de acordo com o $\S$ único do artigo $2^{\circ} \mathrm{c} / \mathrm{c} /$ artigo 88, I do Código de Processo Civil, notificou as Representadas para apresentação de suas defesas. Porém, ao cabo de sua análise, a SDE concluiu, que não houve há indícios de participação das empresas Representadas no cartel investigado, mas sim das empresas matrizes sendo que as filiais brasileiras deveriam ter sido utilizadas apenas para fins de notificação das empresas estrangeiras que cometeram a infração contra a ordem econômica.

Tal entendimento, contudo, não foi avaliado em última instância administrativa pelo CADE, pois o Conselho reconheceu de plano a incidência da prescrição intercorrente e 
arquivou a investigação, não enfrentando questões secundárias. Assim, o Conselheiro Relator do caso, Carlos Emmanuel Joppert Ragazzo, concluiu em seu voto vencedor:

Por outro lado, a ausência de maiores elementos que esclareçam o vocábulo "efeitos" do artigo $2^{\circ}$ caput do Diploma Antitruste Brasileiro é refletida também na jurisprudência, que tampouco definiu parâmetros mais detalhados para qualificar o termo mencionado pelo dispositivo. É certo, no entanto, que o voto vencedor no caso trouxe importantes argumentos e fatos para consubstanciar que o cartel de vitaminas, reconhecidamente praticado na Europa, produziu suficientes efeitos no Brasil a ponto de resultar na sua condenação pelas autoridades brasileiras. Referido voto ${ }^{109}$, assim, para fins de configuração dos efeitos no mercado brasileiro, ressaltou que ainda que não existisse nenhuma fábrica das referidas vitaminas na América Latina com exceção de uma filial da BASF, com

\footnotetext{
${ }^{109}$ Constata-se que em toda a América Latina não existe nenhuma unidade produtora de vitaminas, excetuando-se uma pequena unidade da BASF localizada no Brasil para a produção de vitamina B5, conhecida como pantotenato de cálcio, e tão-somente para uso veterinário. Além desta fabrica da BASF, encontram-se também poucas plantas industriais de processamento e transformação de formas oleaginosas das vitaminas A e D em forma de pó, comercializadas exclusivamente no mercado de produtos veterinários. (...) Considerando-se, pois, que o mercado brasileiro de vitaminas é provido quase que totalmente por importações, e a partir dos dados da Secretaria da Receita Federal-SFR/MF, repassados pela SEAE, (...) percebe-se que a soma das participações dos mercados indica uma forte concentração dos mercados dessas vitaminas, configurando uma posição de dominância incontestável dessas empresas. Contudo, para além da posição de dominância incontestável dessas empresas, é possível concluir pela existência de um reflexo direto sobre o mercado brasileiro das condutas ilícitas praticadas na Europa. Tal conclusão é imediatamente verificável a partir da comparação com os dados que constam da Comissão Européia (itens 166 a 168), na qual se vê que a participação de mercado das representadas em nível mundial para as vitaminas A e E. (...) Outra linha de comprovação que converge para a formação de que o cartel apontado não poderia mesmo deixar de produzir seus deletérios efeitos no Brasil se refere à estrutura organizacional das empresas envolvidas, bem como à similitude na comunicação com suas respectivas matrizes. (...) A estrutura organizacional desses grupos, considerando-se suas ramificações nos negócios de vitaminas no Brasil, permite reconhecer, por si só, a possibilidade de propagação dos efeitos do cartel praticado no exterior. (...) Por todo o exposto acima, considero que, pelo menos no que se refere à divisão de mercados entre as representadas, as provas são suficientes para concluir não apenas pela potencialidade de efeitos danosos ao mercado brasileiro senão pela sua efetiva e concreta constatação. Na verdade, os indícios coligidos permitem presumir, como faz a SDE, que os efeitos nocivos desse cartel sobre o mercado brasileiro de vitaminas tenham se propagado de forma muito mais importante do que os dados disponíveis nos autos permitem quantificar. Nesse sentido, há que se mencionar que estudos realizados por pesquisadores estrangeiros estimam que o impacto desse cartel no Brasil ao longo de toda sua duração (1990-1999) levou a um prejuízo de mais de 183 milhões de dólares com o sobrepreço pago sobre as importações de numerosos tipos de vitaminas. (BRASIL, 2007, p. 14)
} 
base nos dados da Receita Federal, o mercado nacional era quase que totalmente abastecido por importações provindas das empresas internacionais participes do cartel.

Assim, o CADE concluiu que os efeitos danosos do cartel internacional de vitaminas estavam configurados tendo em vista que o mercado brasileiro era, à época que operou o cartel, abastecido quase que $100 \%$ pelo mercado internacional por meio de importações das empresas matrizes das subsidiárias brasileiras na Europa, as quais eram as representadas no processo e já haviam sido condenadas na Europa pela conduta, algumas inclusive tendo reconhecido sua culpa. Também considerou que a documentação probatória indicava que a coordenação das quantidades e preços das vitaminas a serem vendidas no Brasil era determinada pelas empresas matrizes. Entendeu, dessa forma, que o mercado brasileiro foi prejudicado já que as vitaminas eram exportadas para o Brasil e aqui chegavam como resultado do conluio deflagrado no exterior com alcance mundial. De tal modo que, ausente a concorrência entre as empresas matrizes, as vitaminas comercializadas no Brasil - todas provenientes das sedes das representadas no estrangeiro - tiveram seu preço majorado em razão da existência do cartel.

\section{Extraterritorialidade da Defesa da Concorrência: análise de $\mathbf{4 2}$ jurisdições}

Diante da globalização da economia do mundo, é inexorável que as investigações de cartéis sejam enfrentadas simultaneamente por várias jurisdições. Faz-se assim fundamental conhecer as características da aplicação da jurisdição extraterritorial pelas agências de defesa da concorrência no mundo, quando previstas em suas legislações, e saber as circunstâncias em que tais instrumentos foram aplicados.

Da pesquisa conduzida pela publicação Global Competition Review, do ano de 2010, 40 das 42 jurisdições pesquisadas informaram que adotam em seus ordenamentos 
jurídicos de defesa da concorrência mecanismos para o exercício extraterritorial da jurisdição. São elas: África do Sul, Alemanha, Argentina, Austrália, Áustria, Bélgica, Brasil, Canadá, China, Chipre, Coréia do Sul, Eslovênia, Dinamarca, França, Grécia, Hungria, Índia, Irlanda, Israel, Itália, Japão, Letônia, Lituânia, Luxemburgo, Macedônia, Nigéria, Noruega, Nova Zelândia, Países Baixos, Polônia, Portugal, Reino Unido, Rússia, Suécia, Suíça, Turquia e Ucrânia. A União Europeia também afirmou positivamente. Chile e Colômbia não estabelecem em suas legislações nenhuma previsão para o exercício da jurisdição extraterritorial em matéria concorrencial. Em relação ao Chile, foi informado que o Diploma Antitruste Chileno, DL n. 211, é válido e aplicável somente dentro do território do país. Já a legislação de defesa da concorrência da Colômbia não se estende aos fatos ocorridos fora do país.

Dos 40 países que informaram dispor de dispositivos de exercício de jurisdição extraterritorial, todos confirmaram que as legislações internas de defesa da concorrência consagram a teoria dos efeitos para a aplicação da extraterritorialidade. Dos 40 países que afirmaram que adotam a teoria dos efeitos para fins de determinação da jurisdição extraterritorial, três deles, Coreia do Sul, Estados Unidos da América e Nova Zelândia - além da União Europeia - reportaram terem se valido desse dispositivo recentemente, conforme melhor detalhado na sequência.

A Coreia do Sul reportou que, em 2002 e 2003, seu órgão antitruste aplicou sanções administrativas consubstanciadas em multas pecuniárias às empresas estrangeiras que participaram dos cartéis de eletrodos de grafite e de vitaminas. Em 2008, o órgão também aplicou multas em quatro empresas que participaram do cartel asiático de papel, em uma investigação iniciada através do programa de leniência e que foi conduzida em cooperação com as autoridades antitrustes da Austrália.

Os Estados Unidos da América informaram que a teoria dos efeitos é aplicada às situações em que a conduta anticompetitiva praticada fora do país produz efeitos "substantivos" e "intencionais" no território estadunidense, conforme jurisprudência 
estabelecida pelo caso Hartford Fire Ins Co vs. Califórnia (1993). Nos termos da decisão de primeira instância do caso USA vs. Nippon Paper Industries Co. (1997), ficou estabelecido que a jurisdição estadunidense de seu principal Diploma Antitruste, o Sherman Act, é igual para casos de natureza civil e criminal. A Suprema Corte ainda não endereçou essa questão.

A Nova Zelândia, por sua vez, informou que, nos termos da decisão em Harris vs. Comissão do Comércio (2009), as cortes neozelandesas têm jurisdição sobre o "ato ou omissão que resultar na prática, consentimento ou autorização de entendimentos anticompetitivos que for direcionado ao mercado neozelandês e que for 'implementado' no território", mas ressaltou que esta decisão pende de apelação pela Suprema Corte do país. Ademais, participantes de cartel serão considerados presentes na Nova Zelândia quando tiverem meramente participado de comunicações no país através de faxes, e-mails ou telefonemas, consistentemente com dispositivos iguais aos da legislação antitruste contidos na legislação de comércio internacional, conforme o caso Commerce Commission vs. Discount Premium Holidays \& Ors (2007). Adicionou que o órgão antitruste tem tomado medidas contra as empresas estrangeiras, por exemplo, no caso do cartel dos quadros de distribuição isolados a gás (Gas Insulated Switchgear - GIS) em que os investigados eram empresas europeias que tinham operações no país através de suas subsidiárias. Também, em outros dois casos recentes, Commerce Commission vs. Koppers Arch Wood Protection (NZ) Ltd [2007] 2 NZLR 805 e Commerce Commission vs. Visy Board (NZ) Ltd [11 June 2009] HC, Auckland, CIV-2007-404-7237, todos os indivíduos que figuram no polo passivo da investigação residem fora da Nova Zelândia.

A União Europeia citou o artigo 101 do Tratado de Funcionamento da União, o qual é aplicado às partes localizadas fora da União Europeia, mas cujas atividades ilícitas produziram efeitos na concorrência dentro da União Europeia. Em termos gerais, justifica-se a aplicação da teoria dos efeitos em relação aos cartéis internacionais nas situações em que os acordos anticompetitivos tenham "imediatos" e "substanciais" efeitos na União Europeia. Citou também casos de cartéis em que esse entendimento foi exposto: realçadores de sabor (2002), videotape (2007), bananas (2008) e mangueiras marítimas (2009). 


\section{Capítulo III - A Cooperação no combate aos cartéis internacionais: instrumentos existentes e características}

\section{Panorama mundial no combate aos cartéis internacionais}

A partir deste ponto, será apresentada uma breve introdução sobre o panorama mundial no combate aos cartéis internacionais, com o recrudescimento da aplicação das leis nas Américas, Europa, Ásia-Pacífico, Oriente Médio e África.

No final da última década, a defesa da concorrência presenciou desenvolvimentos gigantescos em todo o mundo, marcando-se como período em que o combate aos cartéis internacionais se tornou prioridade para as agências. $\mathrm{O}$ aumento do número de países que passou a criminalizar as condutas de cartel transformou para sempre o cenário mundial do Direito Antitruste. Das 23 jurisdições europeias pesquisadas que reportaram regular a conduta de cartel internamente, onze impõem sanções penais à conduta de cartéis. Países como a Grécia e a Eslovênia aplicaram penas máximas para os condenados do cartel. Quatro países nas Américas do Norte e do Sul passaram a ter legislações nacionais que criminalizam a conduta de cartel. Países da Ásia, do Oriente Médio e da África também recentemente passaram a perseguir criminalmente os indivíduos e empresas participantes de cartel.

A tendência global verificada para a criminalização do cartel tem sido acompanhada pelo crescimento dos programas de leniência, que resultaram em pagamentos milionários de multas pelas empresas multinacionais condenadas pela conduta. Países que recentemente adotaram ou revisaram seus programas de leniência incluem Áustria, Bélgica, Bulgária, China, Chipre, República Tcheca, Dinamarca, Finlândia, França, Alemanha, Grécia, Hungria, Irlanda, Israel, Itália, Japão, Coreia do Sul, Letônia, Lituânia, Luxemburgo, Holanda, Nova Zelândia, Noruega, Polônia, Portugal, Romênia, Rússia, Singapura, Eslováquia, 
Espanha, Suécia, Suíça, Turquia, Reino Unido, Estados Unidos e também a Comissão Europeia,. Os programas de tais países são semelhantes e compartilham o objetivo de dissuasão e detecção de cartéis, incentivando a delação e cooperação para a identificação dos demais participantes com a promessa de obtenção da isenção das multas.

A proliferação de países que ativam e agressivamente reprimem os cartéis tornou muito mais caro para as empresas enfrentarem os processos de investigação de cartéis internacionais, mesmo quando resolvem assinar acordos de cessação da prática com a autoridade. O benefício associado com este tipo de resolução de processo é normalmente uma multa inferior àquela que seria aplicada à empresa caso não tivesse ela se disposto a confessar o ilícito e encerrar a investigação através do pagamento de um montante.

Para fazer jus aos benefícios de isenção das penas administrativa e criminal, o candidato ao programa de leniência em uma jurisdição precisa admitir sua culpa na participação da conduta ilícita. Com efeito, dada a crescente cooperação e compartilhamento de informações entre as agências de defesa de concorrência para o combate aos cartéis, o candidato pode ser pressionado a confessar a prática ilícita enquanto que em outra jurisdição o candidato pode tentar defender sua inocência.

O notável ritmo de mudança ao redor do mundo no combate aos cartéis demonstra o crescente e efetivo interesse na identificação e condenação de tais condutas. Esta maior atenção aos cartéis provocou em países anteriormente isentos de legislações de defesa da concorrência o desejo de se tornarem mais ativos e de coordenarem com outros países seus esforços no combate dessas condutas. Como o número de países que proíbem as atividades colusivas aumentou, assim também aumentaram as multas que estão sendo impostas às empresas. Além disso, embora ainda tímidas em termos mundiais, as penas de prisão para os indivíduos estão se tornando cada vez mais comuns, particularmente para os indivíduos condenados nos Estados Unidos da América. Essas mudanças tendem a continuar na nova década. A seguir, fazemos uma síntese da compilação da pesquisa, elaborada pela publicação Global Competition Review (GCR) em 2010 em 42 jurisdições sobre a matéria. 


\subsection{Américas}

Mudanças recentes nas regulamentações sobre cartéis nas Américas do Norte e do Sul acentuam o crescente foco sobre as condutas anticompetitivas. Dos seis países das Américas do Norte e do Sul que relataram suas legislações a respeito de cartéis para a GCR, quatro- Estados Unidos da América, Canadá, Brasil e Argentina - têm sanções penais para a prática de cartel.

Nos Estados Unidos da América, a execução criminal antitruste continua a ser uma grande prioridade da Divisão Antitruste do Departamento de Justiça (DoJ). Nos últimos anos, o DoJ aumentou seu foco no ajuizamento de processos em face de indivíduos. Desde maio de 1999, mais de trinta réus estrangeiros cumpriram ou estão atualmente cumprindo pena de prisão no país pela participação em cartéis internacionais.

Em março de 2009, o Canadá alterou sua legislação sobre a defesa da concorrência estabelecendo como prática criminosa os acordos colusivos para a fixação de preços sobre produção e fornecimento. As alterações também significaram um aumento das penalidades criminais pela prática de cartel: empresas ou indivíduos podem ser multados em até US\$25 milhões e indivíduos podem ser presos por até catorze anos.

Multas civis por violação à legislação antitruste nas Américas também estão se desenvolvendo. Por exemplo, a Lei de n. 1340, de julho de 2009, da Colômbia, aumentou a multa civil para indivíduos que violarem a legislação de 300 para 2.000 salários mínimos mensais (de US\$69 mil para US\$500 mil). Igualmente, a mesma multa para empresas subiu de 2 mil salários mínimos mensais (US\$500 mil) para 100 mil (US\$24 milhões) ou, se superior, até $150 \%$ do lucro da empresa. 
O Chile alterou o Decreto Lei n. 211 de 1973 (DL 211), o que aumentou a multa civil máxima que pode ser imposta para indivíduos ou empresas para US\$26 milhões e estabeleceu um programa de leniência que oferece imunidade total para a primeira empresa que fornecer informação substancial para a autoridade competente (Fiscalía Nacional Económica-FNE) sobre o cartel e 50\% de redução na multa para os candidatos subsequentes.

\subsection{Europa}

Dos 23 Estados membros da União Europeia que relataram suas legislações a respeito de cartéis para a GCR, onze processam cartéis criminalmente. Cinco Estados membros - Áustria, Alemanha, Itália, Polônia e Turquia - também possuem sanções criminais para a prática de fraude às licitações. Nos últimos seis meses, Grécia e Eslovênia aumentaram suas penas de prisão para condutas individuais de cartel.

Em junho de 2008, a autoridade antitruste do Reino Unido (Office of Fair Trading - OFT) processou criminalmente três empresários que estavam envolvidos no cartel das mangueiras marítimas. Eles foram sentenciados em 20 a 30 meses de prisão após declararemse culpados das acusações de fixação de preços e fraude às licitações. Em setembro de 2009, o OFT também impôs uma multa de $£ 39,27$ milhões às empresas que formaram um cartel que visava a boicotar novos entrantes e fixar taxas.

A Comissão Europeia impôs mais de $€ 1,3$ bilhão em multas por infrações concorrenciais em 2009. Em novembro de 2009, a Comissão Europeia impôs multas que totalizaram $€ 173$ milhões a 24 empresas pela fixação de preços de aditivos plásticos. Também notável é a multa imposta a dois dos maiores fornecedores de gás da Europa que atingiu mais de $€ 553$ bilhões, para cada um, por acordarem em não competir no mercado nacional de gás natural um do outro. Em novembro de 2008, a Comissão Europeia impôs a maior multa a 
cartéis da história - €1,4 bilhão - a quatro produtores de vidro de carro por divisão de mercado em quotas e fixação de preços.

A investigação internacional de fretes aéreos realça a cooperação transatlântica cada vez mais sofisticada entre as autoridades. Em 2006, as autoridades dos Estados Unidos da América e da Europa instauraram uma investigação sobre a colusão entre as maiores empresas da indústria de frete aéreo para fixação de preços. No final de 2009, o DoJ já havia conseguido declarações de culpa de 15 empresas representadas e havia imposto mais de US\$1,6 bilhão em multas às transportadoras de carga aérea. Em fevereiro de 2009, a Comissão Australiana de Concorrência e do Consumidor multou as empresas Martinair, Cargolux e Air France em A $\$ 17,3$ milhões. A autoridade antitruste canadense (Canadian Competition Bureau) processou e impôs mais de C\$10 milhões em multas à Air France, KLM e Martinair em junho de 2009. A autoridade japonesa (Japanese Fair Trade Commission - JFTC) determinou que onze empresas japonesas de transporte pagassem um total de ¥8,4 bilhões em 2009 devido a formação de um cartel para fixar taxas de frete aéreo que causaram danos ao mercado japonês.

Em março de 2009, a autoridade concorrencial francesa lançou o guia revisado de seu programa de leniência. O guia de consulta descreve o mínimo de evidências necessárias para o aproveitamento total ou parcial da desejada imunidade. As empresas que pleiteiam a imunidade devem fornecer às autoridades antitrustes francesas informações e evidências relevantes a respeito da existência do cartel e de suas atividades. Outras condições devem ser preenchidas de forma cumulativa: a empresa deve cessar seu envolvimento no suposto cartel, cooperar plenamente com a autoridade concorrencial durante toda a investigação e impedir a destruição ou falsificação de evidências do cartel.

A Grécia recentemente alterou o artigo 29 da Lei $n^{\circ}$ 703/1977 a fim de robustecer as sanções criminais impostas a membros de cartéis. Sob a nova legislação, qualquer individuo que, individualmente ou como representante de uma entidade legal, participar de um cartel pode ser multado de $€ 15$ mil até $€ 150$ mil. As modificações também aumentaram a pena máxima de prisão de três para seis meses. Em 2009, a Comissão Grega de Concorrência 
(Greek Competition Commission - GCC) multou quatro grandes seguradoras em €32,5 milhões por fixação de preços. Em 2008, a GCC impôs €50 milhões em multas a British Petroleum e Shell por colusão para fixar descontos oferecidos a donos de postos de gasolina na Grécia.

Em junho de 2009, a Hungria também modificou sua legislação de defesa da concorrência - a Lei LVII, de 1996, sobre Práticas Ilegais de Mercado e Restrições à Concorrência. Sob a nova legislação, indivíduos envolvidos em cartéis podem ser presos por até cinco anos. As mudanças também introduziram um regime de leniência sofisticado. Embora o programa apenas se aplique a cartéis hard-core, que são aqueles definidos como acordos ou práticas concertadas entre um ou dois concorrentes envolvendo fixação de preços, divisão de mercados ou fixação de quotas, a política de leniência húngara oferece imunidade total e parcial para multas. A primeira empresa a cooperar recebe imunidade completa. A imunidade parcial é concedida para aquelas posteriores que fornecerem um claro valor adicionado às provas e evidências já submetidas à autoridade sobre o cartel.

As alterações de junho de 2009 na legislação concorrencial da Eslovênia seguiram a tendência internacional em direção à criminalização das práticas de cartel. As modificações aumentaram substancialmente as penalidades criminais para a conduta de cartel e estabeleceram o primeiro programa de leniência. Indivíduos podem ser presos por até cinco anos e multados em até $€ 1$ milhão. O programa de leniência da Eslovênia se aplica a membros de cartéis que cessarem suas participações na conduta, enviarem provas que auxiliem na investigação e cooperarem com a autoridade concorrencial (Slovenian Competition Protection Office). A primeira empresa a cooperar recebe redução de 30 a 50 por cento na aplicação das multas. A multa da segunda empresa candidata poderá ser reduzida de 20 a 30 por cento e todos os candidatos subsequentes poderão receber uma redução de 20 por cento das multas.

Recentes alterações na legislação da Macedônia sobre a defesa da concorrência criminalizaram as condutas que possam "impedir, restringir ou falsear a concorrência resultando em dano material de grande valor". Embora a responsabilidade penal seja imposta 
apenas a indivíduos, as penalidades são severas: eles podem ser sentenciados a até dez anos de prisão e multados em até 250 salários mínimos mensais.

$\mathrm{Na}$ fronte Eurasiana, recentes alterações no Código Penal Russo estabeleceram a responsabilização criminal por "ações de restrição da concorrência, fixação de preços, contratos desarrazoadamente elusivos e imposição de restrições à entrada no mercado". Desde outubro de 2009, a prática de cartel tornou-se punível com até sete anos de prisão, multa de um milhão de rublos ou o equivalente a cinco anos do salário do indivíduo punido. As modificações também expandiram a responsabilização penal pessoal de altos executivos por “crimes relacionados à concorrência".

\section{3. Ásia-Pacífico}

Quatro dos sete países do eixo Ásia-Pacífico que foram entrevistados para a GCR informaram processar tal conduta em âmbito criminal. As recentes alterações nas legislações sobre de cartéis do Japão e da Austrália, indicaram um aumento nas penas máximas previstas para indivíduos. Alterações no artigo 35 do Decreto de Aplicação da Lei da Coreia também revolucionaram o seu programa de leniência.

O Parlamento australiano aprovou em 16 de junho de 2009 a emenda à Lei de Práticas Comerciais Ilegais. Esta nova legislação, que entrou em vigor em julho do mesmo ano, segue a abordagem dos EUA no que tange aos processos criminais contra indivíduos e empresas por condutas anticompetitivas. Aos indivíduos, pode ser aplicada uma pena de prisão máxima de 10 anos e multas de até A\$220 mil. As empresas podem ser multadas em até 10 por cento dos seus lucros anuais no ano anterior da condenação. De acordo com a referida emenda, uma pessoa não deve fazer, ou dar causa, a um contrato, acordo ou entendimento que contenha "previsão de formação de cartel". Multas civeis para participação em cartel foram 
também aumentadas: as empresas podem ser multadas em até A \$ 10 milhões por prática anticompetitiva e os indivíduos podem ser multados em até A $\$ 500$ mil.

A emenda à Lei da Concorrência do Japão (2010) foi promulgada em $1^{\circ}$ de janeiro de 2010. A emenda majorou as sanções penais para condutas colusivas de mercado. Especificamente, aumentou a pena máxima para a prática de cartel ou fraude à licitação de três para cinco anos. Empresas podem ser multadas em até $¥ 500$ milhões e os indivíduos podem ser multados em até ¥ 5 milhões. A emenda de 2010 também inclui uma previsão específica que permite um aumento de 50\%em multas civeis se: (i) a empresa premeditar a conduta caracterizada como "restrição excessiva ao comércio em violação da Lei da Concorrência"; (ii) solicitar a outra empresa que realize ato considerado violação à Lei da Defesa da Concorrência; (iii) ou impeça que outras empresas cessem a prática de tal conduta. A nova legislação também permite que até cinco empresas se candidatem ao programa de leniência

japonês. Os três últimos candidatos, no entanto, só poderão receber uma redução de até 30\%nas multas impostas. A agência competente (Japanese Fair Trade Commission - JTFC) também anunciou que contará com uma coordenação especial para as investigações internacionais de cartéis, exclusivamente para atuar no combate a cartéis transfronteiras. Antes dessas alterações, pedidos de leniência conjuntos não eram permitidos na Coréia do Sul. Agora, as empresas afiliadas que pertencerem ao "mesmo grupo econômico" poderão apresentar pedidos de leniência conjunta. As alterações também permitirão "movimentos ascendentes na lista de leniência" se houver uma retirada voluntária de um pedido de leniência melhor posicionado no ranking.

\subsection{Oriente Médio e África}

A crescente onda de combate aos cartéis avançou para o Oriente Médio e África. Israel criminalizou a conduta de cartel em 1988 e a África do Sul está em vias de introduzir 
em sua legislação sanções penais por prática de cartel. O Estatuto de Israel que regula a prática de cartel - Práticas Restritivas de Comércio, Lei n 5748/1988 - impõe sanções penais aos indivíduos membros de cartel. Os indivíduos podem ser multados em até 2 milhões de shekels israelenses e presos por até três anos pelo crime de cartel ou até cinco anos se a prática for cometida em "circunstâncias agravantes".

Durante a última década, vários executivos têm cumprido sentenças de prisão em Israel por crimes de cartel. Em 28 de agosto de 2009, o presidente sul-africano Jacob Zuma assinou emenda à Lei Concorrencial (a Emenda) que entrará em vigor "em data a ser definida pelo presidente Zuma, após preocupações constitucionais terem sido extirpadas”. A alteração prevê novas sanções penais para os indivíduos e inclui penas de até 10 anos e multas de até 500 mil rand. De acordo com a emenda, um diretor executivo ou qualquer outra pessoa com autoridade gerencial em uma empresa estará sujeita à punição se fizer com que a empresa pratique a conduta de cartel ou "deliberadamente consentir no compromisso da empresa em prática de cartel, tendo conhecimento de tal conduta". A emenda também alterou o programa de leniência da África do Sul para que tanto indivíduos como empresas possam fazer uso de tal ferramenta.

A partir do levantamento da pesquisa da GCR, os seguintes países já criminalizam a conduta de cartel de acordo com suas legislações: África do Sul, Alemanha, Argentina, Austrália, Áustria, Bélgica, Brasil, Canadá, Chipre, Dinamarca, França, Grécia, Hungria, Irlanda, Israel, Japão, Coreia do Sul, Macedônia, Nigéria, Noruega, Polônia, Romênia, Rússia, Eslovênia, Suíça, Turquia, Reino Unido e Estados Unidos da América. Por outro lado, as exceções são: Chile, China, Colômbia, Índia, Itália: Letônia, Lituânia, Luxemburgo, Holanda, Nova Zelândia, Portugal, Suécia, Ucrânia e União Europeia. 


\section{Seção I - Cooperação multilateral e convergência: a soft law aplicada}

\section{Os fóruns multilaterais: cenário mundial}

Principalmente no âmbito da política econômica, tem-se tornado cada vez mais comum no Direito Internacional a ocorrência do soft law, ou seja, a utilização de diversos instrumentos que geram deveres nas relações mútuas entre pessoas de Direito Internacional, mas sobre as quais é acordado, expressa ou implicitamente, que são desprovidos de caráter jurídico; ou, ainda, são formulados textos que dificultam a caracterização do acordo como jurídico (VIRALLY, 1984).

Um dos benefícios das normas não vinculantes do Direito Internacional é a maior participação dos atores envolvidos nas questões discutidas, como empresas, técnicos, experts, representantes de populações locais (em casos envolvendo desenvolvimento sustentável), o que não ocorre nas negociações de instrumentos jurídicos internacionais clássicos, nos quais acabam prevalecendo os interesses hegemônicos. Há, portanto, o surgimento de um direito transnacional que ultrapassa o Direito Internacional Público e a regulação estatal (KOSKENNIEMI, 2004).

Esse fenômeno tem como causa a conjuntura econômica internacional extremamente flutuante dos dias de hoje e a intensificação das relações internacionais contemporâneas de que resultam situações difíceis de submeter ao Direito (VIRALLY, 1984).

Dentre os argumentos apresentados na doutrina, merecem destaque os principais fatores que levam à opção pela soft law em detrimento das convenções mais solenes do Direito Internacional (chamados na doutrina americana de hard law): a flexibilidade e a celeridade, possíveis na medida em que são dispensados os trâmites constitucionais de adoção do instrumento de Direito Internacional no ordenamento doméstico. 
No que tange à existência de conteúdo jurídico, há divergências doutrinárias quanto à verdadeira natureza da soft law. Parte majoritária da doutrina tem como pressuposto que o principal elemento para a constituição de uma norma jurídica no âmbito internacional é o consenso, já que, nesse contexto, não há falar em um órgão superior legitimado à edição de normas. Partindo dessa premissa, os instrumentos de soft law produzidos pelos Estados não são fontes autônomas do Direito Internacional porque os Estados poderiam celebrar um tratado, mas optaram por não fazê-lo (NASSER, 2005).

Não se deve sequer utilizar o termo "law" na designação desses instrumentos, pois, para ele, a base da formação das normas jurídicas internacionais é o consenso. Se não há consenso sobre a obrigatoriedade do quanto disposto em determinado instrumento, trata-se, então, de regra do jogo (rule of the game), termo que seria muito mais apropriado (AREND, 1999).

Outra parcela da doutrina, bem menos expressiva, não é a denominação que se dá à norma internacional que vai definir se ela é juridicamente vinculante (hard) ou se não o é (soft law) (KRATOCHWIL, 1989); é, na verdade, a decisão no caso concreto, seja proveniente de uma Corte Internacional ou de um juiz no âmbito doméstico que, ao decidir uma contenda, definirá a natureza da norma. ${ }^{110}$ ${ }^{110}$ Kratochwil (1989, p. 203-204) cita como exemplo o caso da propriedade cultural nigeriana, julgado na Corte
Constitucional Alemã. O caso versava sobre o seguro contratado, na Alemanha, para o transporte de artefatos
africanos de Porto Harcourt para Hamburgo. Durante o transporte, seis figuras de bronze foram perdidas e a
seguradora recusou-se a pagar, sob o fundamento de que, de acordo com o Código Civil Alemão (BGB), os
contratos contra bonos mores são proibidos. Havia, à época, uma lei nigeriana que proibia a exportação e
transferência de propriedade cultural do país e ainda um instrumento de soft law adotado como recomendação
pela UNESCO em 1964, também com o objetivo de proibir e prevenir a transferência de propriedades culturais.
Posteriormente à edição da recomendação, foi celebrada uma convenção com o mesmo objetivo, ratificada pela
Nigéria mas não pela Alemanha Ocidental. Como o acordo havia sido celebrado na Alemanha, deveria incidir a
lei civil alemã e não as normas internacionais não vinculantes. A Corte, entretanto, entendeu, com base na
convenção e nas recomendações, que esses instrumentos expressavam "convicções fundamentais " da
comunidade internacional de que cada país tem o direito de preservar suas heranças; assim, a violação desses
princípios não merecia a proteção das normas de Direito Privado. A prática da transferência dos artefatos não se 
Uma terceira corrente, apesar de não caracterizar a soft law como fonte de Direito Internacional vinculante, reconhece que esses instrumentos têm efeitos jurídicos. Essa corrente é a que melhor explica o fenômeno dessas normais flexíveis.

Ao analisar o caso específico das recomendações firmadas no âmbito das organizações internacionais, conclui-se que, apesar de seu caráter não vinculante, seus efeitos práticos são indiscutíveis e podem ser classificados como explicativos, programáticosinovativos, legitimadores ou terminativos (SCHREUER, 1988).

No caso das recomendações do Comitê da Basileia, fica evidente sua principal característica: a de ser programático-inovativa, dado o expresso intuito de uniformizar a regulação do sistema bancário em todo o mundo, inovando, de fato, os sistemas jurídicos internos de cada país.

Sobre a questão da natureza jurídica desses instrumentos, apresenta outra perspectiva: para ele, a questão sobre se as recomendações são juridicamente vinculantes não é o cerne do problema. Na prática, a importância legal ou a autoridade das recomendações podem variar de acordo com fatores como a posição e o respeito pelo órgão, sua composição, seu papel como órgão principal ou acessório, a autoridade nele investida pelos poderes conferidos e o respeito por suas atividades anteriores.

No mesmo sentido, os destinatários das recomendações não são obrigados a se submeterem e não cometem infrações em caso de desrespeitarem-nas; entretanto, reconhecem nesses instrumentos um valor normativo e as possíveis sanções políticas decorrentes do descumprimento de seu conteúdo. Acrescentam, ainda, dois requisitos aos apresentados por Schreuer para analisar o alcance dos efeitos das recomendações: o quorum alcançado em sua

coadunava com a "boa moral" (good morals) e, no interesse da preservação da decência no comércio internacional, a seguradora foi declarada perdedora. 
votação, a importância dos Estados que exprimem reservas nesta ocasião e a existência ou não de mecanismos de controle de aplicação das recomendações (DINH; DAILLER; PELLET, 2003).

Considerando o caso concreto, tanto o BIS como o Comitê da Basiléia ocupam posição extremamente relevante no sistema financeiro internacional, porque têm como missão proporcionar a cooperação entre bancos centrais e outra agência em busca da estabilidade monetária e financeira. E, mais importante, atuam como banco central dos bancos centrais por meio de atividades como: fórum de discussão e análise de políticas entre os bancos centrais, juntamente com a comunidade financeira internacional; centro de pesquisa econômica e monetária; principal parceiro dos bancos centrais em suas transações financeiras; agente ou trustee de operações financeiras internacionais ${ }^{111}$.

O BIS oferece, ainda, um largo espectro de serviços financeiros para dar suporte aos bancos centrais e outras instituições financeiras oficiais na administração de suas reservas de moeda estrangeira. A influência mais óbvia da soft law na conduta dos Estados por meio da regulação e de parâmetros de conduta é exercida pelas organizações internacionais que têm reais benefícios a distribuir, como serviços ou empréstimos - exatamente o caso do BIS. Chama a atenção, ainda, para o problema ainda não resolvido de que esses concertos internacionais, muitas vezes, não envolvem todos os países por eles afetados e que os problemas substantivos de Direito Internacional raramente são devidamente enfrentados.

Confrontando-se os critérios apresentados por Schreuer (1988) e Dinh, Dailler e Pellet (2003) com as características do BIS e do Comitê da Basiléia, pode-se dizer que é bem considerável a relevância jurídica dos Princípios da Basiléia II, motivo pelo qual o presente trabalho adere a essa terceira corrente. É em razão da importância dessa organização, que

111 Informações institucionais disponíveis em no portal do BIS, recuperado em 6 de março de 2010, em www.bis.org.br. 
ocupa posição central na regulação do sistema financeiro mundial (o que se verifica na sua relação com bancos centrais e demais órgãos reguladores) e do fato de que há participação direta em operações financeiras internacionais. Há, ainda, dentro do Comitê da Basiléia, o Grupo de Implementação do Acordo (Accord Implementation Group), responsável por acompanhar a implementação de suas resoluções. Por óbvio, esse grupo não tem poder de autuar nenhum país que descumpra os critérios formulados, mas, em um mercado em que a fidúcia é componente fulcral, o simples fato de dar conhecimento ao mundo de que um mercado não segue as medidas de prevenção de riscos já representa uma importante forma de coação política e, até, financeira. Soma-se a isso o fato de que o Banco Mundial e o FMI têm exigido a adoção dos princípios da Basiléia como requisito para concessão de empréstimo.

\subsection{OMC}

O comércio internacional vem desempenhando um papel cada vez mais importante na economia mundial. A atestar tal importância estão os dados dos fluxos de comércio da década de 1990 que vêm crescendo a uma taxa média de 7\% em valor, enquanto a taxa média de crescimento do produto industrial para o mesmo período é de apenas $3 \%$.

O valor do comércio mundial de bens atingiu, em 1997, a cifra de cerca de US\$ 5,5 trilhões, com taxa de crescimento de 3\% em relação a 1996. O valor do comércio de serviços, em 1997, cresceu 2\% em relação a 1996 e atingiu a cifra de cerca de US\$1,3 trilhões (OMC, 1998). Na área de investimentos, o fluxo de investimentos estrangeiros diretos, em 1996, atingiu a cifra de US\$ 350 bilhões enquanto que o estoque de investimentos estrangeiros diretos foi estimado em US\$ 3,2 trilhões (UNCTAD, 1997).

Desses totais, os países desenvolvidos são responsáveis por aproximadamente $66 \%$ das exportações mundiais e $65 \%$ do fluxo dos investimentos diretos. Papel de destaque deve 
ser dado às empresas transnacionais que, em 1996, foram responsáveis por um total de vendas de US\$ 6,4 trilhões, incluindo as áreas de bens e serviços e, mais ainda, foram responsáveis por cerca de $60 \%$ das exportações mundiais (UNCTAD, 1997).

Diante do quadro antes apresentado, fica evidente que o cenário atual é marcado por uma densa rede de comércio e investimento, que evoluiu de forma a determinar os contornos do atual cenário internacional.

A mais importante consequência desse novo cenário é o fim das fronteiras entre políticas domésticas e políticas externas, principalmente a de comércio externo.

Tal fato exige que o comércio de bens e serviços e a área de investimentos passem a ser coordenados em níveis multilaterais e que as regras de conduta dos parceiros comerciais passem a ser controladas e arbitradas também em nível internacional.

Dentro do contexto internacional, a OMC, criada em janeiro de 1995, é a coluna mestra do novo sistema internacional do comércio. A OMC engloba o GATT, o Acordo Geral de Tarifas e de Comércio (concluído em 1947), os resultados das sete negociações multilaterais de liberalização de comércio realizadas desde então e, ainda, todos os acordos negociados na Rodada Uruguai, concluída em 1994.

O acordo que estabelece a OMC determinou os objetivos da nova organização. Os termos negociados foram os seguintes:

As Partes reconhecem que as suas relações na área do comércio e atividades econômicas devem ser conduzidas com vistas à melhoria dos padrões de vida, assegurando o pleno emprego e um crescimento amplo e estável do volume de renda real e demanda efetiva, e expandindo a produção e o comércio de bens e serviços, ao mesmo tempo que permitindo o uso ótimo dos recursos naturais de acordo com os objetivos do desenvolvimento sustentável, procurando proteger e preservar o 
ambiente e reforçar os meios de fazê-lo, de maneira consistente com as suas necessidades nos diversos níveis de desenvolvimento econômico ${ }^{112}$.

Ponto básico para a consecução desses objetivos é a liberalização do comércio de bens e, agora, de serviços, principalmente através do desmantelamento das barreiras impostas nas fronteiras ao comércio entre os países. A OMC tem basicamente quatro funções ${ }^{113}$. A primeira é Facilitar a implantação, a administração, a operação e os objetivos dos acordos da Rodada Uruguai, que incluem: setores diversos como agricultura, produtos industriais e serviços; regras de comércio como valoração, licenças, regras de origem, antidumping, subsídios e salvaguardas, barreiras técnicas, e empresas estatais; supervisão dos acordos regionais e sua compatibilidade com as regras do GATT; propriedade intelectual; e, novos temas como meio ambiente, investimento e concorrência. A segunda é constituir um foro para as negociações das relações comerciais entre os estados membros, com objetivo de criar ou modificar acordos multilaterais de comércio. A terceira é administrar o Entendimento (Understanding) sobre Regras e Procedimentos relativos às Soluções de Controvérsias, isto é administrar o "tribunal" da OMC. A última é administrar o Mecanismo de Revisão de Políticas Comerciais (Trade Policy Review Mechanism) que realiza revisões periódicas das Políticas de Comércio Externo de todos os membros da OMC, acompanhando a evolução das políticas e apontando os temas que estão em desacordo com as regras negociadas ${ }^{14}$.

Com tais objetivos e funções, o sistema multilateral de comércio vem se consolidando nos últimos anos através da OMC, que conta atualmente com 132 membros e cerca de 30 membros em processo de acessão. As atividades vêm se desenvolvendo dentro de

\footnotetext{
${ }^{112}$ GATT. The Results of the Uruguay Round of Multilateral Trade Negotiations. 1994.

${ }^{113}$ GATT. The Results of the Uruguay Round of Multilateral Trade Negotiations. 1994

${ }^{114}$ GATT. The Results of the Uruguay Round of Multilateral Trade Negotiations. 1994
} 
quatro conselhos, aproximadamente 35 comitês, além dos grupos de acessão de novos membros.

Os objetivos do GATT/OMC ao longo das cinco décadas da sua história sempre enfatizaram a liberalização do comércio através do estabelecimento e aplicação de regras para a remoção de barreiras nas fronteiras. No entanto, tais objetivos vêm sendo questionados diante do novo contexto mundial. Atualmente, as políticas nacionais estão sendo cada vez mais influenciadas pelos acontecimentos internacionais, as empresas transnacionais estão desempenhando papel cada vez mais importante no comércio e a estratégia da globalização está agora ditando as regras de investimento e de avanços tecnológicos.

Diante desse contexto, surgem novas discussões sobre o papel que a OMC deve desempenhar e quais novos objetivos a organização deve perseguir. Tais discussões já abrangem uma abordagem mais ampla para a OMC: não só de liberalização do comércio, via o exame dos instrumentos de política comercial, mas de uma nova análise que incluiria os instrumentos das diversas políticas econômicas e seus impactos sobre a competição internacional, além do modo de operação dos mercados (FEKETEKUTY, ROGOWSKY, 1996).

Dentre as razões apontadas para a necessidade de uma nova abordagem estão os métodos de produção dirigidos à globalização e ao consumidor, que acabaram com a distinção entre as estratégias de comércio e de investimentos. Antes, comércio e investimento eram considerados atividades alternativas para se penetrar no mercado externo. Agora, na era da globalização, as empresas tratam comércio e investimento como atividades complementares. Cada vez se torna mais difícil implantar regras sobre a troca de bens que envolvam origens nacionais distintas.

$\mathrm{Na}$ área de serviços, temas como comércio, investimento e movimento dos prestadores são pontos básicos das negociações sobre liberalização.

Com a globalização, a identidade nacional dos produtos e das empresas que os fornecem fica cada vez mais difícil de ser identificada. Como consequência, as novas regras para o comércio internacional devem enfocar o impacto de todas as políticas econômicas sobre o funcionamento dos mercados globais, sujeitas às exigências econômicas de melhor 
eficiência e às políticas de tratamento justo aos interesses de outros países por parte dos governos. O tratamento não discriminatório para produtos e para empresas, sejam nacionais ou estrangeiros, passou a ser um dos grandes temas do momento atual.

O processo de globalização tem resultado em um aprofundamento da especialização internacional e na interpenetração das economias nacionais. Isto significa que os interesses econômicos das nações passaram a se interpenetrar, de modo a tornar sem significado a tradicional distinção entre instrumentos de política econômica doméstica e instrumentos de política econômica internacional. Assim, toda medida que tenha impacto na decisão de produção de bens ou serviços de uma empresa globalizada se tornou tema de interesse para o governo de outros países e para a comunidade internacional, tanto do lado do produtor quanto do lado do consumidor.

Diante dessas considerações é que se tem advogado uma nova postura para o comércio internacional, até agora sob uma abordagem de simples liberalização das fronteiras, para uma abordagem mais ampla e orientada para a competição internacional. As razões defendidas são de que tal abordagem enfocaria mais diretamente os impactos das medidas sobre o funcionamento eficiente dos mercados globais, bem como passaria a incluir um conjunto mais amplo de instrumentos de políticas que afetassem a competição internacional. Com a nova abordagem, toda a argumentação de defesa da liberalização do comércio internacional permanece válida, mas é ampliada pela nova abordagem.

Com o fortalecimento do processo de globalização, todo o sistema multilateral do comércio deveria passar por profundas modificações, caso uma nova abordagem orientada para a competição internacional se impusesse ao processo de liberalização do comércio internacional. Os objetivos do sistema multilateral de promover a eficiência e o crescimento econômico agora deveriam também incluir políticas e instrumentos que permitissem maior competição internacional entre as empresas, de modo a garantir uma alocação de recursos economicamente eficiente, tanto em termos estáticos quanto dinâmicos. Tais objetivos passariam a exigir acesso equivalente a insumos e consumidores, além de tratamento equivalente sob a regulamentação doméstica, não importando a origem da empresa. 
Nesse novo cenário, as novas negociações multilaterais de comércio teriam necessariamente que incluir novos temas como: políticas e medidas que discriminassem as empresas entre si, com base na nacionalidade dos detentores do capital; leis e medidas que impedissem ou distorcessem desnecessariamente a operação das forças do mercado, ou ainda que limitassem a entrada e saída das empresas; e, ainda, políticas e medidas essenciais para o funcionamento eficiente do mercado global. Cada governo nacional manteria os seus direitos de estabelecer e atingir seus objetivos sociais nas áreas da saúde, segurança, igualdade social e ambiente (FEKETEKUTY; ROGOWSKY, 1996).

Dentro dessa nova abordagem, as futuras negociações internacionais continuariam o processo de desmantelamento das barreiras já identificadas como tarifas, quotas, barreiras técnicas, subsídios, dumping, práticas das empresas estatais, barreiras no comércio de serviços e de padrões de propriedade intelectual.

Mas, novos temas seriam incluídos como: medidas que afetam os investimentos, práticas comerciais restritivas ou medidas que distorcem a concorrência, medidas ambientais que afetam o comércio e padrões trabalhistas, entre outros. A razão seria de que qualquer prática discriminatória em qualquer dessas políticas poderia afetar os objetivos estabelecidos de se assegurar a competição global.

Diante do novo contexto internacional de globalização do sistema produtivo e de prestação de serviços, que tem dado sustentação ao crescimento dos fluxos de comércio e de investimentos, é importante ter em mente a ampliação do papel da OMC como pilar central de todo o sistema multilateral do comércio.

A OMC já iniciou a discussão sobre diversos dos novos temas que vêm afetando o comércio internacional, com a criação de novos comitês ou grupos de trabalho para analisar seus impactos e discutir a necessidade de se ampliar as atividades da OMC com a negociação de novos acordos sobre o comércio. Dentre eles, investimentos, concorrência e meio ambiente. Paralelamente, vem seguindo as discussões sobre o tema padrões trabalhistas na Organização Internacional do Trabalho (OIT), com refletões sobre as consequências de também incluí-lo no âmbito da OMC. 
As atividades de todos esses comitês e grupos de trabalho se revestem de mais importância ainda diante das pressões políticas e econômicas de se iniciar mais uma rodada multilateral de negociações (a Rodada do Milênio), ou de forma restrita, com os temas já previstos na Rodada Uruguai e que incluem agricultura, serviços e propriedade intelectual, ou, de forma mais ampla, agregando todas as áreas relacionadas ao comércio.

Atividades transfronteiriças de comércio e de investimento têm sido consideradas como fenômenos econômicos distintos, com diferentes características e efeitos, e, como tais, sujeitos a regulamentações governamentais diferentes.

Atualmente, no entanto, comércio e investimentos estão sendo considerados como estreitamente relacionados, cada um possuindo um papel essencial no processo de integração internacional e de globalização. Cada um deles surge como meio para atingir as economias de escala e expansão de mercados, maior escolha e menores preços para os consumidores, transmissão de tecnologia e práticas modernas de administração, que são essenciais para a eficiência econômica e o desenvolvimento (OECD, 1997).

Questões relativas à presença no mercado ou ao acesso ao mercado como, por exemplo, o conjunto de condições que regulam a permissão para as firmas se estabelecerem e operarem nos mercados estrangeiros tem assumido um papel central na interpenetração das economias e são consequência da expansão das atividades transfronteiriças da última década. Nesse processo, comércio e investimento passaram a apresentar uma complementaridade crescente. As empresas que operam no mercado internacional têm considerado o comércio e o investimento como meios complementares para desenvolverem atividades de produção global, e não como estratégias alternativas para penetrarem no mercado.

Vários organismos internacionais têm analisado os temas de comércio e de investimento ao longo dos anos, desenvolvendo um número expressivo de pesquisas nessas áreas, além de negociarem instrumentos formais, obrigatórios ou voluntários para seus membros. Dentre eles, estão a OCDE, o Banco Mundial, o FMI e a UNCTAD. Vários acordos regionais também têm negociado regras para a interface entre comércio e investimento, como o NAFTA, a APEC, a ASEAN e o Tratado Europeu sobre a Energia. Além disso, um número 
expressivo de países tem demonstrado grande interesse em negociar regras bilaterais relacionadas ao comércio e ao investimento.

Recentemente, presenciou-se um aumento significativo de acordos bilaterais para a promoção e proteção do investimento estrangeiro. Um levantamento da UNCTAD relata que, em 1997, o número de BITs (Bilateral Investment Treaties) era de 1310, envolvendo cerca de 160 países, sendo que mais da metade desses tratados surgiu depois de 1990 (UNCTAD, 1997).

A multiplicidade de acordos sobre investimentos tem levantado a necessidade de se criar regras internacionais sobre o tema. Algumas das razões apontadas seriam (LOW; SUBRAMANIAN, 1999): (i) um acordo internacional com obrigações sobre investimentos, incluindo disposições sobre solução de controvérsias, forneceria continuidade política e maior segurança para novas oportunidades de investimento; (ii) os governos que liberalizaram seus regimes de investimento poderiam usar um quadro de referências multilateral de compromissos sobre investimentos de forma a dificultar o movimento reverso ao da liberalização; (iii) uma ação concertada dos governos reforçaria o processo de liberalização; (iv) um quadro de referência internacional garantiria que os inúmeros acordos regionais não operariam de modo a fragmentar a economia internacional; (v) um acordo internacional sobre investimentos exerceria um forte efeito inibidor contra a guerra de incentivos para atrair novos investimentos.

\subsection{OCDE}

A inter-relação entre as políticas sobre o comércio externo e sobre a concorrência tem sido reconhecida na área internacional há muitos anos. Inúmeros trabalhos sobre o tema têm sido apresentados por organismos internacionais, dentre eles, a OCDE, o Banco Mundial e o FMI. Tais organismos passaram a reconhecer a necessidade de um trabalho mais sistemático 
sobre as relações entre políticas de comércio, de investimento e de concorrência, de modo a melhorar a coerência das políticas e apoiar o bom funcionamento do sistema multilateral do comércio.

Desde 1967, a OCDE vem desenvolvendo análises e recomendações na área da concorrência, através de seus grupos de trabalho, baseada nas premissas de que: as práticas anticompetitivas do setor privado podem restringir o acesso ao mercado; medidas sobre o comércio podem restringir a concorrência; e, as regulamentações do governo podem restringir o acesso ao mercado e à concorrência.

As análises da OCDE concluíram que a eficácia da lei sobre a concorrência depende de uma série de fatores, entre eles, a cobertura e a abrangência das leis, o real cumprimento das leis e a identificação das práticas restritivas que devem ser incluídas nas leis. Tais práticas foram divididas em três categorias: acordos horizontais, como os cartéis internacionais, cartéis de exportação, alianças estratégicas e fusões; restrições verticais, como a integração da produção ou de prestação de serviços; e, o abuso da posição dominante, como restrição a entrada ou preço predatório (OCDE, 1997).

A OCDE (1995) também vem elaborando uma série de recomendações que têm caráter não obrigatório, mas incluem um instrumento de notificação entre as agências que cuidam de concorrência.

Em 1991, a American Bar Association (ABA) elaborou um relatório intitulado International Antitrust e concluiu que a elaboração de uma lei anticoncorrência internacional não seria possível, uma vez que, embora os cartéis fossem tratados como formalmente ilegais, muitos países excluíam certos tipos de cartéis das suas leis de defesa da concorrência (AMERICAN BAR ASSOCIATION, 1991).

Em 1993, um grupo formado por 12 acadêmicos, o Grupo de Munique, tomou uma posição oposta e divulgou o International Antitrust Code, propondo a sua inclusão no GATT através de um acordo plurilateral (FOX, 2003). 
Em 1995, a Comissão da União Europeia formou um grupo de especialistas que elaborou um relatório sobre concorrência, também recomendando a negociação de um acordo plurilateral dentro da OMC. O Report on Competition Policy in the New Trade Order (COMMISSION OF EUROPEAN COMMUNITIES, 1995) foi elaborado por acadêmicos e funcionários da Comissão e depois adotado pelo Conselho da CE como posição da comunidade junto à OMC. A abordagem é a de uma construção progressiva da coordenação das políticas da concorrência (building blocks). As etapas seriam as seguintes: (i) adoção de legislação sobre concorrência em nível nacional, incluindo estrutura administrativa pelos membros interessados em participar do acordo. Tal legislação deveria incluir regras sobre os principais temas: acordos restritivos, abuso de posição dominante e fusões, bem como instrumentos de investigação e sanções apropriadas, com garantia de acesso das partes privadas às autoridades domésticas e às cortes judiciais; (ii) adoção de regras comuns, através da identificação de princípios comuns, bem como a adoção de tais regras em nível internacional, de modo a promover condições iguais de concorrência, e facilitar a cooperação das autoridades, promovendo uma gradual convergência das leis da concorrência; (iii) estabelecimento de um instrumento de cooperação entre as autoridades, incluindo notificações, troca de informações, e cooperação; (iv) estabelecimento de um mecanismo de solução de controvérsias, adaptando o mecanismo da OMC para as especificidades dos casos de concorrência.

\subsection{ICN}

A Rede Internacional da Concorrência (International Competition Network - ICN) foi criada em outubro de 2001 por 14 autoridades de órgãos antitruste do mundo com objetivo de promover a convergência global em matéria de concorrência e prover um fórum independente e especializado nessa matéria. A proposta surgiu em 2000 no relatório do Comitê de Aconselhamento de Política de Concorrência Internacional dos Estados Unidos 
(ICPAC), composto por especialistas em concorrência de vários setores, que funcionou entre 1997 e 2000 a fim de avaliar os desafios das políticas antitruste para o século XXI. A proposta de criação da ICN foi endossada pela Direção Geral para Concorrência da Comissão Europeia e por profissionais de grande destaque nas áreas de concorrência pública e privada.

A ICN iniciou suas atividades como uma rede virtual composta por autoridades da concorrência. Posteriormente, teve sua estrutura institucionalizada, período em que foram estabelecidas as suas áreas de atuação, seus critérios de admissão e as competências dos grupos de trabalho criados e do steering group.

Formada por autoridades de concorrência nacionais ou multinacionais, organizações não governamentais, organismos internacionais (como a OCDE, a OMC e a UNCTAD), comunidades acadêmicas e setores privados relacionados à concorrência, essa rede é composta, atualmente, por mais de uma centena de autoridades de concorrência.

A ICN é dirigida por um steering group composto por 15 autoridades de concorrência, seguindo um critério geográfico, com mandato de dois anos. Tem como função: estabelecer, designar e recomendar a composição dos grupos de trabalho que desenvolvem os projetos aprovados nas conferências anuais; revisar e aprovar o plano de trabalho para cada projeto desenvolvido pelos grupos de trabalho; preparar e distribuir agendas e documentos nas conferências e encontros; e, aprovar a agenda e os participantes não membros na conferência anual. Como a ICN não conta com um secretariado permanente, as despesas de organização e de secretariado são financiadas, anualmente, pelo país que recebe a conferência anual.

A operacionalização dos trabalhos na ICN se dá através da constituição de grupos de trabalho (working groups), com base em um projeto específico a ser desenvolvido, compostos por autoridades dos países membros e convidados (como especialistas) indicados pelo presidente (chair) do grupo. Os resultados das discussões são convertidos em relatórios que identificam os diferentes posicionamentos dos membros. Cada working group pode ser dividido ainda em dois ou mais subgrupos, de acordo com a especialização do assunto dentro do tema maior do grupo. 
Atualmente, a ICN conta com os seguintes Grupos de Trabalho (GT): Advocacia da Concorrência, Efetividade de Agências de Defesa da Concorrência, Cartéis, Fusões e Aquisições e Condutas Unilaterais. Os GTs são compostos por autoridades dos países membros e convidados (i.e., especialistas), na qualidade de consultores não governamentais (NGAs), indicados pelo presidente do grupo.

As conferências anuais representam o "carro-chefe" das atividades da ICN, nas quais são apresentados os resultados dos grupos de trabalho e as autoridades de concorrência analisam e fazem recomendações sobre os novos projetos e o progresso dos projetos em curso. As recomendações são estabelecidas por consenso entre os membros e funcionam apenas como diretrizes para cada país membro (sem vinculação), sendo, portanto, as autoridades de concorrência livres quanto ao prazo e a forma de implementação das diretrizes. Ao final de cada conferência há um encontro dos representantes do steering group para discutir o progresso dos grupos de trabalho, dos projetos em curso e dos futuros.

No ano de 2012, o Brasil teve a oportunidade de sediar o evento, realizado no Rio de Janeiro, de 17 a 20 de abril. A conferência, organizada conjuntamente pelo CADE, a SDE e a SEAE, contou com representantes de 82 jurisdições, somando, aproximadamente, 500 participantes, sendo 400 internacionais. .

Com base nos princípios colocados pela OCDE e relatados na Seção 1.1 acima, o Relatório do Grupo de Trabalho de Cartéis do International Competition Network elenca quatro categorias que englobam os tipos de informações que poderiam ser trocadas entre as jurisdições: (i) informações públicas. Neste caso, uma agência simplesmente ajuda outra agência a dar celeridade à investigação ao fornecer informações que já são de domínio público. Por exemplo, um relatório sobre as características do mercado investigado difícil de ser encontrado ou informações de mercado decorrentes de estudos feitos pela agência; (ii) informações da agência. Diz respeito às informações que não estão necessariamente em domínio público, mas que são geradas pela própria agência e não foram fornecidas pelas partes para investigação (embora possam ser baseadas em dados fornecidos pelas partes). 
Estas “informações das Agências” podem se referir ao estágio alcançado pelas investigações, o cronograma planejado para os próximos passos, as conclusões prévias da investigação e as conclusões obtidas sobre a natureza do mercado, entre outros; (iii) informações das partes já em poder de uma agência. Este tipo de material pode ser a prova de uma infração ou ainda informações sobre o mercado ou das atividades das partes (como, por exemplo, valores de faturamento). Estas informações podem ser fornecidas voluntariamente (através de uma leniência, por exemplo) ou de forma compulsória (em uma inspeção, busca e apreensão, mediante intimação, dentre outros); (vi) informações obtidas pelas partes a pedido de outra agência. Quando duas agências possuem um nível altamente desenvolvido de cooperação, pode ser possível que uma delas requeira que a outra obtenha informações, ainda não disponíveis, sobre as partes em sua jurisdição. Essa cooperação pode envolver a realização de buscas e apreensões, inspeções, testemunho, envio de intimações, entre outros.

Ainda segundo o relatório do ICN, a cooperação poderia ocorrer em diferentes fases da investigação: (i) na fase pré-investigatória, que é a fase antecedente a coleta de provas. As agências podem cooperar no que se refere aos mercados a serem investigados, às empresas a serem alvo da investigação, ao local da prova e às formas de se evitar a destruição de provas; (ii) na fase investigatória, que é a fase na qual a prova é coletada e analisada, e o caso é formado. As agências podem cooperar para coordenar medidas investigatórias. Tal coordenação pode incluir inspeções, buscas e apreensões simultâneas; envio de notificação ou outros pedidos de informações ou oitivas de testemunhas; e (iii) na fase pós-investigatória, que diz respeito à denúncia, decisão e imposição de penalidades. As agências podem trocar provas e outras informações que tenham obtido e, ainda, podem cooperar através de discussões sobre o caso entre os investigadores.

Resta evidente, portanto, a possibilidade de cooperação efetiva entre jurisdições no combate aos cartéis. No caso de cartéis internacionais, a cooperação é essencial por diversos motivos. Por exemplo, uma jurisdição pode não ter conhecimento da existência de um cartel ou, ainda, a ação coordenada de busca e apreensão de documentos ou inspeções pode evitar a destruição de provas, permitindo uma melhor investigação e desenvolvimento do processo. 


\section{A ascensão dos fóruns multilaterais no Brasil}

No plano das convenções multilaterais, o Brasil tem intensificado sua participação nos mais importantes fóruns internacionais de discussão de políticas de defesa da concorrência, tais como, a $\mathrm{OCDE}^{115}$, a $\mathrm{ICN}^{116}$ e $\mathrm{UNCTAD}^{117}$. Destaca-se que o Brasil tem seguido as recomendações de 2005 da OCDE e da ICN no tocante à cooperação entre os países-membros no combate às praticas anticompetitivas que restrinjam o comércio internacional, sendo membro observador do Grupo de Concorrência no âmbito da OCDE. Tais fóruns internacionais proporcionam aos participantes um importante intercâmbio de experiências nacionais, com a identificação das melhores práticas na condução de investigações de condutas anticompetitivas e na análise de concentrações econômicas que possam ser incorporadas à realidade nacional. E, por fim, promovem o diálogo entre as

${ }^{115}$ A OCDE realiza anualmente reuniões de seu Comitê de Concorrência, com o objetivo de apresentar e discutir experiências em legislação de defesa da concorrência e sua efetiva implementação.

116 Os objetivos da International Competition Network (ICN) podem ser traduzidos pela seguinte assertiva de William Kolansky, procurador-geral da Divisão Antitruste do Departamento de Justiça norte-americano: "The goal of the ICN was twofold. First, to provide support for new competition agencies both in enforcing their laws and in building a strong competition culture in their countries. Second, to promote greater convergence among these authorities around sound competition principles by working together and with stakeholders in the private sector, to develop best practice recommendations for antitrust enforcement and competition advocacy that could then be implemented voluntarily by the member agencies" (KOLANSKY, 2002). Tradução livre: "O objetivo da ICN era duplo. Em primeiro lugar, fornecer suporte para as novas agências de defesa da concorrência na aplicação de suas leis e na construção de uma cultura forte de concorrência nos seus países. Segundo, promover uma maior convergência entre essas autoridades sobre os importantes princípios de defesa da concorrência através de um trabalho em conjunto com as partes interessadas no setor privado, para desenvolver as práticas que recomendadas para aplicação das leis de antitruste e em prol da advocacia da concorrência.

${ }^{117}$ Durante os anos 1950, a Organização das Nações Unidas tomou a iniciativa de tentar controlar as práticas comerciais restritivas através de acordos internacionais. Embora tais esforços tenham tido pouco sucesso, a Assembléia Geral adotou um conjunto de princípios sobre o tema, a pedido dos países em desenvolvimento, mas suas recomendações não tiveram caráter obrigatório. O Conjunto de Princípios e Regras Justas Acordadas Multilateralmente para o Controle das Práticas Comerciais Restritivas foi adotado em 1980, tomando a forma de uma recomendação. 
autoridades das diversas jurisdições, a fim de proporcionar melhores formas de cooperação para lidar com problemas comuns de ordem prática.

A OCDE, a UNCTAD e a ICN são exemplos da chamada soft law ${ }^{118}$, ou seja, são mecanismos multilaterais que não têm caráter vinculativo, mas que se baseiam na premissa de que a persuasão decorrente dos resultados dos trabalhos da instituição e a pressão (peer pressure) entre seus membros por meio da identificação, do desenvolvimento e da adoção de melhores práticas antitruste (reputação em risco) podem tornar efetivos os resultados visados (IVO, 2004). Tais instrumentos estão fundamentados: (a) na soberania individual de cada Estado-membro que adere à convenção de forma voluntária e (b) no compromisso assumido em agir cooperativamente para evitar conflitos de interesses nacionais no âmbito da aplicação das leis antitruste. Não pretendem impor regras materiais vinculativas padronizadas a seus membros, buscando sim incentivar o debate e promover a aproximação entre os órgãos de defesa da concorrência de diversos países com o objetivo da harmonização e convergência espontânea substantiva e procedimental. Em uma era na qual o mundo redefine o conceito de soberania (SLAUGHTER, 2004) em vista dos múltiplos desafios enfrentados pelas relações internacionais contemporâneas, as redes oficiais que propiciam o contato direto entre as autoridades antitruste de diversos países surgem como peças-chaves na busca de um ambiente concorrencial desejável. Entendemos não ser mais factível nem tampouco eficaz que, em pleno século XXI, um Estado cogite construir, desenvolver e aperfeiçoar suas ferramentas de defesa da concorrência de forma unilateral. Se assim o fizer, estará fadado a um isolacionismo ultrapassado e ao absoluto fracasso de suas leis antitruste. Por mais dramática que a assertiva

118 O termo soft law emergiu no contexto da prática reiterada e cada vez mais atuante no século XX da diplomacia multilateral e se refere a instrumentos "quase-legais" que não possuem caráter juridicamente vinculativo, sendo mais brando do que as leis tradicionais, muitas vezes referidas como hard law ou jus cogens. A inadimplência da soft law se dá por um sistema de sanções distintas daquelas previstas nas normas tradicionais, possivelmente assimiláveis às obrigações morais versadas nos sistemas obrigacionais internos dos Estados. Cf. Soares (2003). Para uma análise importante sobre jus cogens, numa perspectiva brasileira, ver artigo de Rodas (1974, p. 125-36). Para uma literatura internacional sobre a distinção entre soft e hard law, ver Abbott e Snidal (2000). 
anterior possa parecer, ela guarda coerência com as igualmente dramáticas transformações sofridas no novo desenho das relações geopolíticas entre os Estados.

Abram e Antonia Chayes (1995) afirmam que "a nova soberania é a capacidade de participar em instituições internacionais que permitam aos membros trabalharem de forma conjunta para a conquista daqueles fins que antes conquistavam sozinhos". Com efeito, a participação do SBDC nessas convenções multilaterais proporcionou efetivamente algumas melhorias na aplicação da antiga Lei de n. 8.884/94.

Destaca-se, por exemplo, a notória influência do instituto norte-americano Amnesty Program ao programa de leniência introduzido pela SDE em 2000 por meio da reforma parcial da Lei de n. 8.884/94. O programa brasileiro, eleito enquanto eixo da política nacional de combate a cartéis, a espelho de seu similar norte-americano, concede àquele participante de cartel que denuncie a prática anticompetitiva às autoridades antitruste e coopere com as investigações, a fim de obter imunidade antitruste administrativa e criminal ou ou reduzir as penalidades aplicáveis. Observa-se, também, que a inserção deste instituto à realidade brasileira decorreu de propostas escritas e discussões entre os representantes das agências dos diversos países-membros da OCDE (GABAN, 2007) que já se utilizavam, com sucesso (SLAUGHTER, 2004), deste meio de investigação e combate aos cartéis e que foram objeto de debates.

Interessante apontar o fato de que nove dos 15 acordos de leniência assinados no Brasil foram firmados com partes envolvidas em cartéis internacionais, em situações nas quais elas assinaram similares acordos em outras jurisdições ${ }^{119}$. Há, inclusive, uma percepção de que tal fato seja decorrente da cooperação formal ou informal entre as autoridades brasileiras e internacionais (ROSENBERG; BERARDO, 2007).

${ }^{119}$ Cf. Lei e Política da Concorrência no Brasil: uma revisão pelos pares - 002010073 @ O OECD / IDB 2010. 
Nitidamente, observou-se uma espiral ascendente promovida pelo networking entre as autoridades antitruste: a cooperação permitiu a inserção de um poderoso instrumento no seio da legislação brasileira de combate aos cartéis, fortalecendo sobremaneira a aplicação da legislação antitruste nacional, e, na sequência, a cooperação promoveu a sua utilização prática.

Também em 2009, outra iniciativa foi a recepção, pela extinta SDE, do consultor da OCDE responsável pelo levantamento de informações e realização de entrevistas que embasaram o Peer Review (Avaliação pelos Pares) do Sistema Brasileiro de Defesa da Concorrência (SBDC). O Peer Review é uma avaliação feita pela organização que apresenta um balanço das características e evoluções do sistema brasileiro de defesa da concorrência nos últimos cinco anos.

A avaliação da OCDE é de suma importância para o SBDC, pois, nos moldes das melhores práticas internacionais, aponta em que e como o país precisa se aperfeiçoar no setor, além de promover a transparência e o entendimento recíproco da política econômica da concorrência dos Estados-membros.

Certo é que tais resultados somente foram possíveis a partir de um esforço do SBDC em convergir com uma agenda multilateral na conquista de uma consistência na aplicação das leis antitruste no mundo.

\section{Principais obstáculos à cooperação internacional no âmbito da defesa da concorrência}

Considerando que os efeitos dos cartéis internacionais são sentidos em mais de uma jurisdição, exsurgem como legítimos mais de um Estado para a investigação e condenação da conduta. Como consequência, levantam-se importantes questões como, por 
exemplo, a aplicação extraterritorial das leis antitruste de cada Estado e a solução de conflitos de competência na aplicação das decisões. As próprias diferenças procedimentais ${ }^{120}$ entre os Estados quanto à aplicação de suas leis de defesa da concorrência, as disposições substantivas das leis, o devido processo legal, o nível de transparência regulatória e os diferentes níveis de maturidade de suas instituições devem ser considerados em qualquer exercício em que se pretenda encontrar um método de repressão às infrações globais.

A título de exemplo, menciona-se que a cooperação entre as autoridades antitruste pode expor uma empresa estrangeira aos treble damages próprios da persecução civil aos cartéis nos Estados Unidos. O risco dessa indenização em triplo foi inclusive citado pela autoridade antitruste canadense (FINCKENSTEIN, 1998) enquanto um obstáculo a uma cooperação mais ampla com os Estados Unidos.

É preciso reconhecer que este talvez seja o mais significativo obstáculo no combate aos cartéis internacionais no contexto da internacionalização da cooperação entre as agências antitruste. Notoriamente, dos Estados com forte tradição antitruste àqueles com pouca ou nenhuma tradição, há leis de defesa da concorrência que possuem viés protecionista, atreladas à análise de fusões e aquisições, sendo certo também que muitos deles se utilizam de mecanismos jurídicos que permitem condutas anticompetitivas contrárias aos consumidores estrangeiros.

Os Estados Unidos, como não poderiam deixar de ser, possuem instrumentos (como o Webb-Pomeren Act, de 1918 (15 U.S.C., §§ 61-65), e o Export Trading Company Act) que conferem imunidade em relação ao Sherman Act e ao Clayton Act, permitindo, de forma deliberada, que empresas norte-americanas formem cartéis de exportação. Outros países como Austrália, Canadá, Israel, África do Sul, Taiwan, Japão e Alemanha possuem ou já

\footnotetext{
${ }^{120}$ Como, por exemplo, distintas técnicas investigativas e diferentes prazos estabelecidos.
} 
possuíram instrumentos jurídicos análogos. Destaca-se que a legislação brasileira da defesa da concorrência não estabelece nenhum tipo de imunidade nesse sentido (ROSENBERG; BERARDO, 2007). Tal estado de coisas demonstra como as autoridades devem estar atentas a estas políticas externas deletérias que - de forma deliberada, consciente e com chancelas governamentais estrangeiras - se apropriam do bem-estar social de outros países.

É notável, contudo, que o fato de um país adotar isenções antitruste não significa que tal isenção seja válida ou aceita em outras jurisdições. Pelo contrário, é largamente reconhecido que outros países retêm jurisdição ampla para perseguir tais associações sem que isso signifique o descumprimento do princípio do direito internacional de não-interferência. Nesse sentido, Martinez (1988, p. 519) cita o caso "Woodpulp" julgado pelo Tribunal de Justiça das Comunidades Europeias. O caso apurou a existência de um acordo de fixação de preços entre produtores de polpa de madeira, em que foi investigada a Pulp, Paper and Paperboard Export Association of the United States, uma associação registrada como cartel de exportação nos Estados Unidos, nos termos do Webb-Pomerene Act. Contudo, há poucos países que, na prática, possuem a habilidade para efetivamente punir tais condutas tendo em vista as dificuldades impostas pela aplicação extraterritorial das leis antitruste.

Conforme Thorstensen (1998), há vários exemplos de práticas anticompetitivas com efeitos internacionais causadas por empresas com suporte do próprio governo, sendo certo que, em algumas vezes, o governo participa diretamente na operação, mas, outras vezes, não aplica a lei anticoncorrência do país para proteger o mercado nacional. Dentre tais exemplos, cita a formação de cartéis de crise, cujo objetivo é a recuperação e restruturação de indústrias em dificuldades; a manutenção de barreiras à entrada no mercado para produtores estrangeiros, com objetivos de proteger a indústria doméstica, através do controle das importações; acordos de preços predatórios para os produtos exportados, mas não para os produtos de venda doméstica; estabelecimento de relações privilegiadas fornecedor-cliente, impedindo acesso ao mercado de fornecedores externos; negociação de acordos voluntários de restrições a exportações, incluindo quantidade e preço, com ou sem a participação do governo; negociação de acordos voluntários de importação, com ou sem a participação do governo; 
cartéis de exportação cujas práticas estão fora da jurisdição das leis internas; concessões de licenças exclusivas; e, barreiras nos canais de distribuição que impeçam a entrada de produtos importados. 


\section{Seção II - Cooperação bilateral: meios alternativos e eficazes da cooperação}

Quando o conflito de interesses nacionais das jurisdições no âmbito das convenções multilaterais é inevitável, os acordos bilaterais estabelecem os procedimentos que buscam resolvê-los de forma construtiva. Tais acordos expressam o interesse comum entre as jurisdições de minimizar quaisquer efeitos adversos relacionados às medidas de implementação de uma jurisdição sobre os interesses da outra na aplicação de suas respectivas leis de concorrência.

Com efeito, a experiência obtida nos acordos de cooperação bilateral tem sido benéfica, tanto no sentido de evitar conflitos de jurisdições na aplicação extraterritorial de leis antitruste, quanto para servir de exemplo em um eventual acordo de cooperação multilateral no que se refere a políticas de concorrência no âmbito global. Ana Maria de Oliveira Nusdeo (2002, p. 170) afirma que:

os principais deveres assumidos pelas partes referem-se à informação recíproca a respeito de atividades potencialmente anticompetitivas realizadas em seu território de que tenham conhecimento e sejam do interesse da contraparte; à informação sobre investigações ou medidas tomadas que possam afetar os interesses da outra parte, podendo requisitar documentos, inquirir testemunhas, realizar buscas, etc. Costumase estabelecer também as cláusulas de cortesia, através das quais as partes se comprometem a levar em consideração os interesses da contratante no desempenho de suas funções. 
Os acordos bilaterais de cooperação entre os Estados em matéria antitruste surgiram enquanto meios mais realísticos e efetivos de lidar com a questão ${ }^{121}$. Através desses acordos, os Estados reconhecem que a cooperação e a coordenação nas atividades de aplicação das leis de concorrência resultam em um atendimento mais efetivo das suas respectivas preocupações do que o que poderia ser alcançado por meio de suas ações independentes.

Um bom exemplo é o acordo de cooperação bilateral celebrado entre o governo dos EUA e a Comissão Europeia em 1991, cuja principal proposta era promover a cooperação e coordenação, diminuindo a possibilidade de impacto resultante das diferenças entre as partes na aplicação de suas leis sobre concorrência (MONTINI, 1999, p. 6). O acordo prevê que cada uma das partes notifique a outra quando for aplicar sua legislação antitruste, caso a aplicação possa vir a afetar os interesses da outra. Prevê também reuniões periódicas entre ambas as autoridades da concorrência, a fim de promover maior convergência na aplicação de suas leis antitruste.

Sem dúvida, a maior inovação trazida por esse acordo foram os chamados positive comity e negative comity principles, traduzidos como princípios de cortesia positiva e de cortesia negativa. Basicamente, pela cortesia negativa (MONTINI, 1999, p. 7), uma das partes leva em consideração os interesses da outra, antes de aplicar sua legislação antitruste contra atos anticompetitivos praticados por ela em seus próprios limites territoriais, podendo inclusive não iniciar uma investigação, que deixaria a cargo do parceiro no $\operatorname{acordo}^{122}$.

Já o positive comity principle ${ }^{123}$, ou princípio de cortesia positiva, consiste em atos positivos de cooperação e assistência recíprocas entre autoridades antitruste nacionais

\footnotetext{
${ }^{121}$ Os dados de 2006 estimavam a existência de 115 acordos bilaterais e 38 acordos multilaterais. Cf. Pesquisa empreendida pela Tuck School of Business Administration at Dartmouth.

${ }^{122}$ Cf. artigo VI do Acordo CE-EUA, de 1991.

123 Positive comity: that policy is that a country should give full and sympathetic consideration to another country's request that it open or expand a law enforcement proceeding in competition cases in order to remedy
} 
localizadas em diferentes países, ao contrário da negative comity, que implica, simplesmente, na decisão de não iniciar uma investigação. Mediante a cortesia positiva ${ }^{124}$, uma das partes, sentindo-se prejudicada por práticas anticompetitivas que ocorram no território da outra, pode notificá-la para que tome as medidas cabíveis em cada caso ${ }^{125}$.

É importante frisar que as disposições do acordo, principalmente no que concerne aos princípios de cortesia, não têm caráter vinculativo para as partes, ou seja, são mecanismos de aplicação voluntária com o intuito de dirimir os conflitos e tensões causados por aplicações unilaterais de leis antitruste nacionais.

Em 1998, os EUA e a União Europeia estabeleceram um novo acordo de cooperação, ampliando os termos do acordo de $1991 \mathrm{e}$, principalmente, tornando mais abrangente o conceito de cortesia positiva ${ }^{126}$. A versão aprimorada do princípio da cortesia positiva estabelece que quaisquer das partes têm o dever de abrir uma investigação contra atos praticados em seu território, sempre que isso seja solicitado pela outra parte. Não obstante, uma parte deve atender ao pedido da outra, mesmo que não haja qualquer violação de sua legislação antitruste interna.

Os EUA também firmaram acordos de cooperação bilateral com a Alemanha, a Austrália, o Canadá e com países em desenvolvimento, como o Brasil. Nota-se que há um

conduct in its territory that is substantially and adversely affecting another country's interests. In addition, the requested country is urged to take whatever remedial action it seems appropriate on a voluntary basis and in consideration of its own legitimate interests. Cf. OCDE (1999). Tradução livre: "Cortesia positiva: a política de que um país deve considerar de forma plena e empática o pedido de outro para instaurar ou expandir uma investigação antitruste para remediar a conduta em seu território que esteja substancial prejudicialmente afetando o interesse do outro país. Além disso, o país requerido é instado a tomar qualquer ação corretiva que pareça oportuno numa base voluntária e tendo em consideração seus interesses legítimos".

${ }^{124}$ Nesse sentido, Ana Maria de Oliveira Nusdeo (2002, p. 171, grifo do autor) esclarece: “...tem-se difundido o uso da chamada cláusula de cortesia positiva, estabelecendo a presunção de deferimento por uma das partes, na aplicação de suas regras de concorrência ao interesse da outra, quando as atividades anticompetitivas forem direcionadas principalmente ao território desta última".

${ }^{125}$ Cf. artigo V do Acordo CE-EUA de 1991.

${ }^{126}$ Cf. artigo III do Acordo CE-EUA, de 1998. 
grande interesse, por parte dos norte-americanos, em ampliar a cooperação antitruste com seus parceiros comerciais, que começou a se manifestar principalmente a partir de 1994, quando o Congresso americano aprovou uma lei que permite a troca de informações confidenciais com outros países; trata-se da International Enforcement Assistance Act (IAEAA), que confere poderes às agências de concorrência para celebrarem acordos de cooperação não apenas no âmbito das trocas de informações sigilosas, mas também no que concerne às modalidades de assistência técnica $^{127}$.

Apesar do interesse norte-americano na cooperação técnica com países em desenvolvimento, cumpre-nos ressaltar que há diferenças em relação aos acordos celebrados pelos EUA com outros países desenvolvidos. Isso ocorre devido à similaridade entre os níveis de desenvolvimento dos sistemas de concorrência desses países, diferentes, por sua vez, dos sistemas de países emergentes, que muitas vezes nem possuem legislação antitruste. Em razão disso, há dois tipos de acordos bilaterais de cooperação, os chamados acordos de primeira geração e os de segunda geração.

Os primeiros objetivam fundamentalmente desenvolver uma cooperação na área da política de concorrência entre seus signatários nos casos de interesse mútuo da aplicação das leis de defesa da concorrência. A maioria desses acordos segue as recomendações da $\mathrm{OCDE}^{128}$, que fornecem alguns instrumentos de cooperação, como a coordenação de atividades, notificações e consultas nos casos de mútuo interesse e a disposição sobre prevenção de conflitos na aplicação das leis de defesa da concorrência, além de estabelecerem o princípio norteador da cortesia positiva.

\footnotetext{
${ }^{127}$ Nesse sentido, Cf. Thorstensen (1998, p. 328) e Nusdeo, A. (2002, p. 171).

${ }^{128}$ A OCDE exarou sua primeira recomendação sobre o assunto em 1967 e a última em 2005. Cf. OCDE (2005).
} 
Para estes tipos de acordos, o acesso às informações confidenciais da outra jurisdição só é permitido caso haja a expressa anuência da parte interessada, o que é muito raro, e, mesmo assim, de modo geral, de forma limitada (OLIVEIRA; RODAS, 2004, p. 385).

Papadopoulos (2006) afirma que, através deles, os Estados criam obrigações normalmente imprecisas de cumprimento voluntário, constituindo-se um pouco mais que uma promessa política e muito menos que um compromisso vinculativo.

Oliveira e Rodas (2004, p. 385) os consideram como soft agreements, uma vez que não têm força de lei nem o mesmo caráter vinculativo dos tratados internacionais (PARISI, 1999), estando subordinados às respectivas leis das jurisdições de cada parte. Também não possuem o condão de afetarem direitos e obrigações das partes decorrentes de outros acordos internacionais dos quais elas participem.

Enfim, acordos de primeira geração são próprios de instituições que ainda não atingiram maturidade institucional para firmarem os acordos de segunda geração, os quais preveem a troca de informações confidenciais entre as autoridades de defesa da concorrência.

Já os acordos de segunda geração, chamados de Acordos de Assistência Mútua em Matéria Antitruste, permitem às autoridades envolvidas trocar informações e documentos confidenciais e protegidos sem que, para isso, seja necessário o prévio consentimento das fontes ou partes envolvidas. Acordos de segunda geração têm um objetivo de troca de informações mais amplo do que o existente nos acordos de primeira geração (PARISI, 1999). Isto, pois, além da troca de informações ocorrer até mesmo contra a vontade das partes envolvidas, elas, em alguns casos, também podem ser transmitidas fora do contexto de informações formais. Alguns exemplos são os firmados entre os Estados Unidos da América e a Austrália e entre os Estados Unidos da América e Canadá, que permitem a troca de informações confidenciais de matéria antitruste nas esferas civil e criminal, sem a necessidade de qualquer autorização para tanto. 
Atualmente, a União Europeia e a Suíça também estão em processo de negociação para a assinatura de um acordo de cooperação de segunda geração (KIRIAZIS, 2007). Entre as cláusulas discutidas para este pacto, estão: somente a permissão de troca de informações que já estão em poder da autoridade antitruste, sendo vedada a coleta de informações para o fornecimento à autoridade do outro país; a transmissão de informações pessoais apenas quando as autoridades de ambos os países estiverem investigando as mesmas condutas ou condutas relacionadas; e a proibição de troca de informações de signatários de acordos de leniência ou de termos de cessação de condutas, a não ser que haja consentimento escrito para tanto.

No plano das iniciativas bilaterais, há também chamados de "Acordos de Cooperação Judiciária e Assistência Mútua em Matéria Penal” (MLATs ${ }^{129}$ ) que objetivam fundamentalmente o incremento da efetividade das ações de prevenção e persecução criminal através de iniciativas de assistência mútua. Podem, assim, constituir outro tipo de instrumento capaz de permitir a cooperação bilateral entre as agências brasileiras e as estrangeiras para fins de promoção e aplicação das leis de defesa da concorrência, aplicáveis somente em conexão com assuntos criminais - como os casos de cartéis internacionais - muito embora não sejam específicos da matéria antitruste, como os acordos acima abordados.

Holmes et al. (2006) argumentam que tais acordos possuem importante papel na internacionalização da defesa da livre concorrência e precisam ser examinados vis-à-vis os acordos que incluem provisões específicas da matéria antitruste.

Representam, em verdade, instrumentos aperfeiçoados de cooperação entre duas jurisdições, aplicáveis às questões criminais clássicas, mas que foram recentemente estendidos às condutas anticompetitivas de caráter criminal, como os cartéis. O referido aperfeiçoamento

${ }^{129}$ Do inglês Mutual Legal Assistance Treaties. 
decorre de provisões que estabelecem um maior nível de cooperação bem como um maior comprometimento entre os Estados com a prestação da cooperação.

Tais acordos costumam designar uma "autoridade central" para fazer e receber as solicitações de assistência e, normalmente, preveem o requerimento à outra parte de fazer uso de suas prerrogativas no âmbito da investigação do crime em que se investiga, incluindo o intercâmbio de informações confidenciais quando em sintonia com a legislação nacional da parte requerida: a tomada de depoimentos, o fornecimento de documentos, registros e bens, a execução de pedidos de busca e apreensão, a localização ou identificação de pessoas físicas ou jurídicas. São instrumentos muito mais poderosos para a efetiva cooperação entre os Estados: a prestação da cooperação é regra devendo a exceção ser justificada pela existência de incompatibilidade entre as leis e interesses essenciais do Estado requerido e/ou os princípios do Direito Internacional e o pedido. Normalmente, também preveem a denegação do pedido de assistência quando o Estado requerido considerar que seu cumprimento interferirá em um processo penal em curso em seu território.

Como dito, além de estabelecerem um maior alcance da assistência mútua, tais acordos constituem vínculos mais fortes de obrigações entre os Estados. Entende-se natural que à medida que se aumenta a amplitude da cooperação, aumenta-se, também, a exigência do compromisso obrigacional quanto à cooperação.

Cumpre esclarecer que estes acordos só serão aplicáveis no caso de haver a previsão da dupla incriminação, quando o cartel for perseguido criminalmente em ambas as jurisdições. Tais como os primeiros instrumentos, os acordos de assistência mútua somente podem ser invocados pelas partes signatárias. 
Importante citar, por fim, que a cooperação caso a caso ocorre tanto sem a invocação formal dos acordos pelas autoridades, na ausência dele ${ }^{130}$, ou, ainda, a despeito dele, quando, por exemplo, o acordo não municia as autoridades com os mecanismos que a cooperação exige em determinada situação.

\footnotetext{
${ }^{130}$ Por exemplo, em outubro de 2007, a pedido do Governo da Angola, a SEAE prestou assistência técnica àquele governo para fins da elaboração da lei de defesa da concorrência do país e capacitação das autoridades angolanas em matéria de antitruste e de regulação. Também em 2007, a SDE participou de algumas iniciativas de assistência técnica à autoridade de defesa da concorrência de El Salvador - sobretudo, para instruir as autoridades em diligências de buscas e apreensões - e do Chile, quando um novo diploma sobre defesa da concorrência estava sendo elaborado. Vale mencionar também que o Brasil e o Chile fazem parte do Projeto Latino-Americano da OCDE sobre Cartéis em Licitações Públicas, que objetiva melhor capacitar os países da região na investigação de tais cartéis. Anualmente, o CADE participa de seminários promovidos pelo Tribunal Espanhol da Concorrência e pela Agência Espanhola de Cooperação Internacional (AECI).
} 


\section{Seção III - A cooperação internacional no Brasil em matéria antitruste no combate aos cartéis internacionais}

O Brasil sempre encarou com elevado espírito de solidariedade internacional o dever que incumbe aos vários Estados de se auxiliarem reciprocamente na repressão dos crimes (VALLADÃO, 1933. p. 463). Nos últimos anos, o Brasil tem adotado algumas iniciativas bilaterais, no âmbito do MERCOSUL e junto às organizações multilaterais, com vistas a munir seu Sistema Brasileiro de Defesa da Concorrência de melhores instrumentais de cooperação interjurisdicional para a persecução dos crimes de cartéis internacionais.

Conforme visto na Seção II acima, a extensão da cooperação entre as agências no combate aos cartéis internacionais depende, sobretudo, dos limites estabelecidos em cada categoria do acordo bilateral. Notadamente, a assistência entre os órgãos prevista em tais instrumentos difere de jurisdição para jurisdição em razão de tais acordos internacionais meramente refletirem a autoridade delegada pelo direito interno para a concessão da assistência no âmbito do Direito Antitruste. Com efeito, é a lei nacional que impõem limites e restrições para prever determinado tipo de assistência. Da mesma forma, a agência cuja assistência foi requerida de sua contraparte estrangeira pode não estar estritamente obrigada a provê-la uma vez que muitos desses instrumentos cooperacionais retratam compromissos mais frouxos e não obrigações absolutas e legalmente vinculativas.

Por essas razões, faz-se fundamental a compreensão da fundamentação do Direito Interno, que embasa os princípios desses instrumentos que autorizam a assistência estabelecida. Em suma, dadas as inúmeras variáveis que afetam a aplicação e o escopo da cooperação estabelecida em cada acordo internacional, é importante a leitura atenta de cada instrumento no contexto legal da jurisdição brasileira. É esta a análise que a seguir se propõe. 


\section{Natureza dos acordos}

\subsection{Acordos de Primeira Geração}

No plano das iniciativas bilaterais de cooperação específicas em matéria antitruste, as quais são normalmente negociadas diretamente entre as agências de defesa da concorrência, o SBDC $^{131}$ assinou acordos de cooperação com a Rússia ${ }^{132}$ (2001), os Estados Unidos da América $^{133}$ (2003), a Argentina ${ }^{134}$ (2003), Portugal ${ }^{135}$ (2005), Canadá ${ }^{136}$ (2008) e Chile ${ }^{137}$ (2008). No âmbito das iniciativas regionais, acordos de primeira geração também foram

${ }^{131}$ Cf. informação disponível no site da SDE, do Ministério da Justiça, recuperado em 26 de junho de 2012, em: http://portal.mj.gov.br/sde/data/Pages/MJ34431BE8ITEMIDA9EA8F7D13D249C1BF0F20E752606414PTBRIE .htm.

${ }^{132}$ Em dezembro de 2001, foi assinado o Acordo entre o Governo da República Federativa do Brasil e o Governo da Federação da Rússia sobre a Cooperação na área da política da Concorrência. Em 2009, o SBDC firmou acordo com o Serviço Federal Antimonopólio da Federação da Rússia. Trata-se de um Programa de Cooperação entre os referidos órgãos para o período 2010-2011.

${ }^{133}$ Em outubro de 1999, foi assinado o Acordo entre o Governo da República Federativa do Brasil e o Governo dos Estados Unidos da América Relativo à Cooperação entre suas Autoridades de Defesa da Concorrência na Aplicação de suas Leis de Concorrência. O acordo somente entrou em vigor em 25 de março de 2003.

${ }^{134}$ Em outubro de 2003, foi assinado o Acordo de Cooperação entre a Republica Federativa do Brasil e a República Argentina Relativo à Cooperação entre suas Autoridades de Defesa da Concorrência na Aplicação de suas Leis de Concorrência. Para um minucioso entendimento do estágio da cooperação entre o Brasil e a Argentina na implementação deste acordo, ver Botta (2009, p. 153-178). O autor conclui que as iniciativas entre os países de cooperação, tanto no âmbito bilateral quanto no Mercosul fracassaram, sobretudo, em razão (1) do desnível de maturidade institucional entre as jurisdições e (2) da falta de comunicação ou contato direto entre as autoridades antitruste de ambos os países.

${ }^{135}$ Em setembro de 2005, foi assinado o Protocolo de Cooperação Técnica entre o SBDC e a Autoridade da Concorrência de Portugal.

${ }^{136}$ Em maio de 2008, foi assinado o Entendimento de Cooperação entre o Conselho da Concorrência, a Agência da Concorrência do Governo do Canadá e o CADE, o SEAE e SDE acerca da aplicação de suas respectivas Normas de Defesa da Concorrência.

${ }^{137}$ Em outubro de 2008, foi assinado o Entendimento de Cooperação entre a Fiscalía Nacional Económica do Chile e o Conselho Administrativo de Defesa Econômica, a Secretaria de Direito Econômica do Ministério da Justiça e a Secretaria de Acompanhamento Econômico do Ministério da Fazenda do Governo da Republica Federativa do Brasil, acerca da aplicação de suas respectivas normas de defesa da concorrência. 
assinados com o Mercosul (2004) e a Comissão Europeia ${ }^{138}$ (2009). A seguir, analisaremos o conteúdo pragmático de cada acordo, abordando, sobretudo, temas fundamentais, tais como, o escopo da cooperação prevista, os limites estabelecidos para a troca de informações e os fundamentos para a negação da cooperação.

O Acordo entre o Governo da República Federativa do Brasil e o Governo da Federação da Rússia sobre a Cooperação na Área da Política de Concorrência foi assinado em dezembro de 2001. Sobre sua vigência, o acordo permanecerá em vigor até a expiração do prazo de seis meses após a notificação escrita de uma das partes sobre a sua intenção de denunciá-lo. Como escopo, tem-se que a cooperação entre as partes se dará nas seguintes direções principais: aperfeiçoamento das bases jurídicas da política de concorrência; realização de medidas práticas para regulação antimonopolista e desenvolvimento de ambiente concorrencial; troca de experiência no campo de revelação de casos ligados à violação da legislação concorrencial; troca de experiência no campo do respeito às regras antimonopolistas na política de comércio exterior; criação de condições favoráveis ao funcionamento eficaz dos mercados de mercadorias e valores; e desenvolvimento da base científica e metodológica para pesquisas no campo do Direito Concorrencial. As formas principais de cooperação entre as partes na área de política de concorrência serão: intercâmbio entre as partes de atos normativos jurídicos, de materiais informativos, metodológicos e outros; prestação de ajuda metodológica, intercâmbio de resultados de pesquisas e promoção de consultas; convite a especialistas da outra parte para participar do processo de ensino e em estágios para a troca de experiências; organização de simpósios, conferências e seminários bilaterais. Sobre a confidencialidade da troca de informações, tem-se que a menos que acordado de forma diferente pelas partes, cada parte deverá manter o máximo de confidencialidade possível sobre as informações a ela fornecidas em sigilo pela outra parte, nos termos deste acordo. Cada parte deverá se opor ao

\footnotetext{
${ }^{138}$ Em outubro de 2009, foi assinado o Memorando de Entendimento de Cooperação entre o SBDC e o DiretórioGeral de Concorrência da Comissão Europeia (DG Competition).
} 
máximo possível e em consistência com as leis daquela parte, a qualquer pedido de uma terceira Parte, de fornecimento de tais informações confidenciais. O presente Programa de Cooperação não é um tratado internacional e não cria direitos ou obrigações sob o Direito Internacional. Sobre os fundamentos para a negação da cooperação, tem-se que nenhuma parte estará obrigada a fornecer informações à outra parte se o fornecimento de tal informação for proibido, segundo as leis da parte detentora da informação, ou se for incompatível com os interesses relevantes daquela parte.

O Acordo entre o Governo da República Federativa do Brasil e o Governo dos Estados Unidos da América Relativo à Cooperação entre suas Autoridades de Defesa da Concorrência na Aplicação de suas Leis de Concorrência foi assinado em março de 2003. Sobre sua vigência, tem-se que o acordo permanecerá em vigor por período de tempo indefinido, a não ser que uma das partes notifique a outra, por escrito, o seu desejo de denunciá-lo. Nesse caso, o acordo permanecerá em vigor por 60 dias após a data da notificação. Sobre o escopo da cooperação, as partes autorizam que funcionários de uma parte possam visitar o território da outra parte no curso de investigações ao amparo de suas respectivas leis de concorrência. Essas visitas deverão estar condicionadas à notificação em conformidade com este artigo e ao consentimento da parte notificada. Também, se uma parte acreditar que práticas anticompetitivas realizadas no território da outra parte afetam adversamente seus importantes interesses, a primeira parte poderá, após consulta prévia à outra parte, solicitar que as Autoridades de Defesa da Concorrência daquela outra parte iniciem qualquer investigação ou procedimento ao amparo de suas leis de concorrência. Também estão previstas atividades de cooperação técnica, tais como: o intercâmbio de informações; o intercâmbio de funcionários dos órgãos de defesa da concorrência para fins de treinamento nos órgãos de defesa da concorrência da outra parte; a participação do pessoal dos órgãos de defesa da concorrência como conferencistas e consultores em cursos de treinamento sobre leis e políticas de concorrência organizados ou patrocinados por suas autoridades de defesa da concorrência; e quaisquer outras formas de cooperação técnica que as autoridades de defesa da concorrência das partes acordarem serem apropriadas para os fins deste acordo. Sobre a confidencialidade na troca de informações, foi estabelecido que a menos que acordado 
de forma diferente pelas partes, cada parte deverá manter o máximo de confidencialidade possível sobre as informações a ela fornecidas em sigilo pela outra parte, nos termos deste acordo. Cada parte deverá se opor, ao máximo possível e em consistência com as leis daquela parte, a qualquer pedido, de uma terceira parte, de fornecimento de tais informações confidenciais. Sobre os fundamentos para a negação da cooperação, tem-se que nenhuma parte estará obrigada a fornecer informações à outra parte se o fornecimento de tal informação for proibido, segundo as leis da parte detentora da informação, ou for incompatível com os importantes interesses daquela parte.

O Acordo de Cooperação entre a República Federativa do Brasil e a República Argentina Relativo à Cooperação entre suas Autoridades de Defesa da Concorrência na Aplicação de suas Leis de Concorrência foi assinado em outubro de 2003. Sobre sua vigência, tem-se que o acordo permanecerá em vigor por período de tempo indeterminado, sendo reservado a quaisquer das partes o direito de denunciá-lo, a qualquer tempo, mediante notificação escrita, à outra parte. Em caso de denúncia, o acordo permanecerá em vigor durante 60 dias após a data de recebimento da notificação pela parte notificada. $\mathrm{O}$ acordo tem por escopo tanto a cooperação na aplicação das leis de defesa da concorrência, quanto a cooperação técnica, bem como garantir que as partes assegurem consideração cuidadosa a seus importantes interesses recíprocos na aplicação de suas leis de concorrência. Também, as partes autorizam que funcionários de uma parte visitem o território da outra parte no curso de investigações ao amparo de suas respectivas leis de concorrência. Essas visitas deverão estar condicionadas à notificação, em conformidade com este artigo, e ao consentimento da parte notificada. As partes acordam ser de interesse comum o compartilhamento das informações que: a) possam facilitar a aplicação efetiva das respectivas leis de concorrência ou b) promovam uma compreensão mais acurada das condições econômicas e mercadológicas de importância para as atividades das autoridades concorrenciais. Se uma parte acreditar que práticas anticompetitivas realizadas no território da outra parte afetam adversamente seus importantes interesses, a primeira parte poderá, após consulta prévia à outra parte, solicitar às autoridades de defesa da concorrência daquela outra parte que iniciem as investigações ou procedimentos apropriados. A cooperação técnica inclui: o intercâmbio de informações; o 
intercâmbio de funcionários dos órgãos de defesa da concorrência da outra parte; a participação do pessoal dos órgãos de defesa da concorrência como conferencistas e consultores em cursos de treinamento sobre leis e políticas de concorrência, organizados ou patrocinados por suas autoridades de defesa da concorrência; e quaisquer outras formas de cooperação técnica que as autoridades de defesa da concorrência das partes acordarem serem apropriadas para os fins deste acordo. É estabelecido que o grau de confidencialidade das informações será decidido pela parte que as detiver, cabendo exclusivamente a esta verificar a possibilidade e o interesse em fornecê-las. Sobre os fundamentos para a negação da cooperação, nada neste acordo exigirá que uma parte tome qualquer medida, ou abstenha-se de agir de uma maneira que não esteja em conformidade com suas leis existentes, ou que exija qualquer mudança nas leis das partes ou de suas respectivas unidades constitutivas de Estado Federal. Da mesma forma, nenhuma parte estará obrigada a fornecer informações à outra parte, em qualquer hipótese, se o fornecimento de tal informação for proibido, segundo as leis da parte detentora da informação, ou se for incompatível com os importantes interesses daquela parte.

O Entendimento sobre Cooperação entre as Autoridades de Defesa da Concorrência dos Estados Partes do Mercosul para a Aplicação de suas Leis Nacionais de Concorrência ("MERCOSUL/CMC/DEC. N. 04/04"), cujos signatários são: Brasil, Argentina, Paraguai e Uruguai, foi assinado em julho de 2004, não tendo disposição específica sobre vigência e denúncia do entendimento. Tem por objetivo promover a cooperação, incluindo tanto a cooperação na aplicação da legislação nacional de concorrência quanto a cooperação técnica entre as autoridades de concorrência, e assegurar que as partes tomem em consideração os importantes interesses recíprocos nas atividades de aplicação da legislação nacional de concorrência. As atividades de cooperação técnica incluem: o intercâmbio de informações; o intercâmbio de funcionários das autoridades de concorrência para fins de seu treinamento na autoridade de concorrência de outras partes; a participação de pessoal das autoridades de concorrência como conferencistas ou consultores em cursos de treinamento relativos à legislação de concorrência organizados ou patrocinados por suas autoridades de concorrência. Uma parte pode autorizar os funcionários de outra parte para que visitem seu território no 
curso de investigações. As partes entendem que é de comum interesse cooperar para a identificação de práticas anticompetitivas e a aplicação de suas legislações de concorrência, de modo a compartilhar informações que facilitem a efetiva aplicação de suas legislações de concorrência e promover o melhor entendimento das políticas e atividades das partes na aplicação da Legislação de Concorrência, na medida em que seja compatível com suas leis e interesses, e dentro dos recursos razoavelmente disponíveis. Se uma parte entende que estão sendo levadas a cabo, no território de outra parte, práticas anticompetitivas que afetam adversamente seus interesses fundamentais, poderá solicitar às autoridades de concorrência da outra parte que iniciem os procedimentos de cooperação previstos neste entendimento. Sobre a confidencialidade na troca de informações, cada parte deve manter a confidencialidade com respeito às informações fornecidas em confidencialidade por outra parte, nos termos do presente entendimento, e não poderá, sem prévia autorização da parte que a proporcionou, fornecer tal informação confidencial a uma terceira parte. Nenhuma parte está obrigada a prover de informações a outra parte, se a provisão da referida informação for proibida de acordo com suas leis ou for incompatível com seus interesses fundamentais. Sobre os fundamentos para a negação da cooperação, o acordo não limita a discricionariedade das autoridades de concorrência da parte solicitada no sentido de condicionar a condução de suas atividades com respeito às práticas anticompetitivas identificadas na solicitação, nem impede as autoridades da parte solicitante de levar a cabo atividades com respeito a tais práticas conforme sua própria legislação.

O Protocolo de Cooperação Técnica entre si que celebram o SBDC e a Autoridade de Defesa da Concorrência de Portugal foi assinado em setembro de 2005, sendo que vigerá pelo prazo de dois anos, podendo ser prorrogado mediante comunicação às partes com a antecedência mínima de sessenta dias e termo aditivo celebrado entre as partes. Inclui atividades de cooperação técnica e compartilhamento de informações e documentos, notadamente, a realização de programas de intercâmbio com vista à partilha de experiências entre os técnicos das partes; promoção e organização de eventos em prol da defesa da concorrência, tais como seminários, fóruns, cursos, palestras, e outros; realização de consultas mútuas sobre temas relevantes para a política de concorrência e intercâmbio de publicações 
entre as partes. Não há dispositivo em específico sobre a confidencialidade das trocas de informações. Sobre os fundamentos para a negação da cooperação, tem-se que é vedado às partes prestar informações a terceiros sobre relatórios decorrentes do presente protocolo ou decididas pelas partes, enquanto a matéria não tiver sido julgada.

O Entendimento de Cooperação entre o Conselho da Concorrência, a Agência de Defesa da Concorrência do Governo do Canadá e o SBDC acerca da Aplicação de suas Respectivas Normas de Defesa da Concorrência foi assinado em Maio de 2008. O Entendimento permanecerá vigente por prazo indeterminado, a não ser que um dos Participantes notifique aos outros, por escrito, de seu desejo de rescindi-lo. Neste caso, o Entendimento estará rescindido para o Participante notificante depois de decorrido o prazo de 60 dias, contados a partir da notificação por escrito. O Entendimento tem por propósito promover a cooperação e a coordenação entre os Participantes. Os Participantes reconhecem que é de interesse comum cooperar e compartilhar informação, quando apropriado e viável. As iniciativas podem incluir as formas de cooperação técnica que os Participantes decidam ser adequadas aos fins deste Entendimento e podem incluir encontros periódicos entre os Participantes para, entre outros; trocar informações relativas à implementação e a prioridade no que se refere às respectivas normas de defesa da concorrência; trocar informações sobre setores econômicos de interesse comum; discutir mudanças nas normas de defesa da concorrência que estejam sob apreciação; e discutir outros assuntos de interesse mútuo relacionados à aplicação de suas respectivas normas de defesa da concorrência ou à operacionalização deste Entendimento. Sobre a confidencialidade na troca de informações, o grau com que um Participante comunica uma informação relativa a este Entendimento a outro Participante pode estar sujeito a, e dependente da aceitação das garantias dadas pelo outro Participante a respeito da confidencialidade das informações e dos fins para os quais ela será utilizada. Exceto se decidido de outra forma pelos Participantes, cada Participante manterá, ao máximo possível, a confidencialidade de quaisquer informações a ela fornecidas em sigilo por outro Participante. Cada Participante será contrário, tanto quanto possível, a qualquer requerimento de tais informações confidenciais feito por uma terceira parte, a menos que o Participante que transmitiu a informação consinta de forma escrita com o seu fornecimento. 
Nada neste Entendimento exigirá que um Participante tome qualquer medida, ou abstenha-se de agir de uma maneira que não esteja em conformidade com suas leis existentes, ou exigirá qualquer mudança nas leis ou regulamentos do Canadá ou da República Federativa do Brasil. Sobre os fundamentos para a negação da cooperação, nenhum Participante é obrigado a comunicar informações a outro se esta comunicação for proibida pelas leis ou regulamentos do Participante que detém esta informação, ou ainda, caso seja incompatível com os interesses daquele Participante na aplicação de suas normas de defesa da concorrência.

O Entendimento de Cooperação entre a Fiscalía Nacional Económica do Chile e o SBDC acerca da Aplicação de suas respectivas Normas de Defesa da Concorrência foi assinado em 2008 e permanece vigente por prazo indeterminado, a não ser que um dos Participantes notifique aos outros, por escrito, de seu desejo de rescindi-lo. Neste caso, o Entendimento estará rescindido para o Participante notificante depois de decorrido o prazo de 60 dias, contados a partir da notificação por escrito. Tem por objetivo promover a cooperação e a coordenação entre os Participantes. Os Participantes reconhecem que é de interesse comum cooperar e compartilhar informação, quando apropriado e viável. As iniciativas podem incluir as formas de cooperação técnica que os Participantes decidam ser adequadas aos fins deste Entendimento e podem incluir encontros periódicos entre os Participantes para, entre outros; trocar informações relativas à implementação e a prioridade no que se refere às respectivas normas de defesa da concorrência; trocar informações sobre setores econômicos de interesse comum; discutir mudanças nas normas de defesa da concorrência que estejam sob apreciação; e discutir outros assuntos de interesse mútuo relacionados à aplicação de suas respectivas normas de defesa da concorrência ou à operacionalização deste Entendimento. O grau com que um Participante comunica uma informação relativa a este Entendimento a outro Participante pode estar sujeito a, e dependente da aceitação das garantias dadas pelo outro Participante a respeito da confidencialidade das informações e dos fins para os quais ela será utilizada. Sobre os fundamentos para a negação da cooperação, nada neste Entendimento exigirá que um Participante tome qualquer medida, ou abstenha-se de agir de uma maneira que não esteja em conformidade com suas leis existentes, ou exigirá qualquer mudança nas leis ou regulamentos do Chile ou da República Federativa do Brasil. Nenhum Participante é obrigado 
a comunicar informações a outro se esta comunicação for proibida pelas leis ou regulamentos do Participante que detém esta informação, ou ainda, caso seja incompatível com os interesses daquele Participante na aplicação de suas normas de defesa da concorrência.

O Memorando de Entendimentos sobre Cooperação entre o SBDC e a Diretoria Geral de Concorrência da Comissão Europeia foi assinado em Outubro de 2009 não havendo dispositivo em específico sobre a vigência do Memorando de Entendimentos. Tem por propósito promover e fortalecer a cooperação e coordenação entre as duas Partes, incrementar seus entendimentos e consciências de suas atuais e futuras políticas, legislação e respectiva aplicação sobre defesa da concorrência. As Partes consideram que é de comum interesse fornecer uma a outra assistência técnica relacionada à aplicação de suas políticas de defesa da concorrência para o propósito de compartilharem experiências e ideias. Tais iniciativas incluem, entre outros, intercâmbio periódico de agentes; promoção e organização de seminários, cursos, fóruns e iniciativas similares; intercâmbio de publicações e outros documentos disponíveis publicamente. Se uma Parte acreditar que condutas anticompetitivas praticadas no território de outra Parte possam afetar adversamente seus importantes interesses, pode requerer atividades apropriadas de enforcement. Sobre a confidencialidade da troca de informações, tem-se que a cooperação está sujeita às respectivas leis de cada Parte e, em particular, àquelas que protegem as informações confidenciais e segredos de negócio. Da mesma forma, as Partes reconhecem que é de comum interesse a troca de informações nãoconfidenciais. Nada neste Memorando de Entendimentos limita a discrição da Parte requerida em decidir se agirá em relação às práticas anticompetitivas identificadas na solicitação. Sobre os fundamentos para a negação da cooperação. Nada neste Memorando de Entendimentos exigirá que uma Parte tome qualquer medida, ou abstenha-se de agir de uma maneira que não esteja em conformidade com suas leis existentes, ou exigirá qualquer mudança de tais leis ou regulamentos. Nenhuma Parte é obrigada a comunicar informações à outra se esta comunicação for proibida pelas leis ou regulamentos do Participante que detém esta informação, ou ainda, caso seja incompatível com os interesses daquele Participante na aplicação de suas normas de defesa da concorrência. Os dispositivos deste Memorando de 
Entendimentos não foram estabelecidos para criar direitos ou obrigações legais no âmbito do direito internacional.

\subsection{Acordos de Segunda Geração}

Não há instrumentos cooperacionais assinados pelo Brasil da categoria dos Acordos de Assistência Mútua em Matéria de Antitruste. Como visto na Seção II acima, tais instrumentos são considerados mais sofisticados e próprios de jurisdições com legislações de defesa da concorrência mais consolidadas uma vez que permitem cooperação mais ampla comparados com os acordos de primeira geração. Não há para o Brasil acordos desta natureza que possibilitariam às agências brasileiras de defesa da concorrência uma cooperação com agências internacionais mais efetiva já que autorizam o intercâmbio de documentos e materiais de natureza confidencial. Tampouco, se conhece legislação nacional que permitiria a execução de tais acordos.

\subsection{Acordos de Cooperação Judiciária e Assistência Mútua em Matéria Penal}

Como visto na Seção II, Item 1.3. acima, os Acordos de Cooperação Judiciária e Assistência Mútua em Matéria Penal constituem outro tipo instrumento capaz de permitir a cooperação bilateral entre as agências brasileiras e as estrangeiras para fins de promoção e aplicação das leis de defesa da concorrência, aplicáveis somente em conexão com assuntos criminais - como casos de cartéis internacionais - muito embora não sejam específicos da matéria antitruste como os acordos acima abordados. 
O Brasil possui acordos dessa natureza firmados ${ }^{139}$ com Itália (1993), Portugal (1994), França (1999), Estados Unidos da América (2001), Colômbia (2001), Peru (2001). República da Coréia (2006), Ucrânia (2006), China (2007), Cuba (2008), Espanha (2008), Canadá (2008), Suriname (2008) e Suíça (2008). A seguir, analisaremos o conteúdo pragmático de cada acordo, abordando, sobretudo, temas fundamentais, tais como, principais características (objetivo, vigência, exigência da dupla incriminação para a devida aplicação, disposição sobre forma e conteúdo) alcances e limitações.

O Tratado sobre Cooperação Judiciária em Matéria Penal, entre a República Federativa do Brasil e a República Italiana foi promulgado pelo Decreto n. 862, de 9 de julho de 1993 e tem por objetivo incrementar ações conjuntas de prevenção, controle e repressão ao delito em todas as suas manifestações, por meio da coordenação de ações e execução de programas concretos, tendo seu término por denúncia. Sobre a necessidade da exigência da dupla incriminação para sua aplicação, tem-se que a cooperação será prestada ainda que os fatos que deram origem ao processo não constituam crime perante a lei da Parte requerida. Para a execução de revistas pessoais, apreensão e sequestros de bens, a cooperação somente será prestada se o fato que originou o processo na Parte requerente for previsto como crime na lei da Parte requerida ou, ainda, se ficar comprovado que o acusado manifestou expressamente seu consentimento. Não faz menção especifica a cartéis e/ou à área de defesa da concorrência e dispõe sobre forma e conteúdo das solicitações. A cooperação compreenderá, especialmente, a comunicação de atos judiciais, o interrogatório de indiciados ou acusados, a coleta de provas, a transferência de presos para fins de prova, a informação dos antecedentes aos cidadãos da outra Parte. Adicionalmente, cada parte pode requerer a outra, informações referentes à legislação e jurisprudência. Tem por limitações: (i) a Cooperação não compreenderá a execução de medidas restritivas de liberdade pessoal nem a execução de

\footnotetext{
${ }^{139} \mathrm{Cf}$. área de cooperação internacional do site do Ministério da Justiça, recuperado em 22 de junho de 2012, em: http://portal.mj.gov.br/data/Pages/MJD6765F39ITEMID9FA8D9D8D00F41539C30491F1BDCD3EAPTBRIE.ht $\mathrm{m}$
} 
condenações, (ii) a cooperação será recusada se os atos solicitados forem vedados pela lei da Parte Requerida, ou contrários aos princípios fundamentais de seu ordenamento jurídico, (iii) a cooperação será recusada se o fato tipificado pela parte requerida for político ou militar, se o acusado já tiver sido julgado pelo mesmo fato na Parte Requerida, e não houver escapado à execução da pena, se a Parte requerida considerar que a prestação da cooperação pode comportar prejuízo à própria soberania, segurança ou a outros interesses nacionais essenciais.

O Tratado de Auxílio Mútuo em Matéria Penal entre o Governo da República Portuguesa e o Governo da República Federativa do Brasil foi promulgado pelo Decreto n. 1.320, de 30 de novembro de 1994, tendo por objetivo melhorar a eficiência na luta contra a criminalidade. Tem seu término por denúncia. Sobre a exigência da dupla incriminação para sua aplicação, há disposição estabelecendo que o auxílio só é prestado relativamente a fatos puníveis segundo as leis de ambas as partes. Não faz menção especifica a cartéis e/ou à área de defesa da concorrência, mas dispõe sobre forma e conteúdo das solicitações. Como alcance, o auxílio compreende, nomeadamente, notificação de documentos; a obtenção de meios de prova; exames de pessoas, lugares ou coisas, revistas, buscas e apreensões de bens; a notificação de suspeitos, arguidos ou indicados, testemunhas ou peritos e a audição dos mesmos; as informações sobre o direito respectivo e as relativas aos antecedentes penais de suspeitos, arguidos ou indicados e condenados. As possibilidades de auxílio previstas no Tratado não limitam qualquer outra modalidade de auxílio em matéria penal que as Partes entendam, caso, mutuamente, concede-se. Tem as seguintes limitações: não se aplica à execução de decisões de detenção ou de condenação, nem às infrações militares que não constituam infrações de delitos de direito comum. É certo também que o auxílio poderá ser recusado pela parte quando: se tratar de infração política ou com ela conexa; o cumprimento do pedido ofender a soberania, segurança, ordem pública ou qualquer outro interesse essencial; o auxílio pode ser recusado se a Parte requerida entender que se verificam fundadas razões que tornariam desproporcionada a concessão de auxílio.

O Acordo de Cooperação Judiciária em Matéria Penal entre o Governo da República Federativa do Brasil e o Governo da República Francesa foi promulgado pelo 
Decreto n. 3.324, de 30 de dezembro de 1999 e tem por objetivo incrementar ações conjuntas de prevenção, controle e repressão ao delito em todas as suas manifestações, por meio da coordenação de ações e execução de programas concretos. Sobre a exigência da dupla incriminação, tem-se que a cooperação será prestada ainda que os fatos que deram origem ao processo não constituam crime perante a lei da Parte requerida. Para a execução de revistas pessoais, apreensão e sequestros de bens, a cooperação somente será prestada se o fato que originou o processo na Parte requerente for previsto como crime na lei da Parte requerida ou, ainda, se ficar comprovado que o acusado manifestou expressamente seu consentimento. Não há menção especifica a cartéis e/ou à área de defesa da concorrência e dispõe sobre forma e conteúdo das solicitações. A cooperação compreende, especialmente, a comunicação de atos judiciais, o interrogatório de indiciados ou acusados, a coleta de provas, a transferência de presos para fins de prova, a informação dos antecedentes aos cidadãos da outra Parte. Adicionalmente, cada parte pode requerer a outra, informações referentes à legislação e jurisprudência. Tem as seguintes limitações: (i) a Cooperação não compreenderá a execução de medidas restritivas de liberdade pessoal nem a execução de condenações, (ii) a cooperação será recusada se os atos solicitados forem vedados pela lei da Parte Requerida, ou contrários aos princípios fundamentais de seu ordenamento jurídico, e (iii) a cooperação será recusada se o fato tipificado pela parte requerida for político ou militar, se o acusado já tiver sido julgado pelo mesmo fato na Parte Requerida, e não houver escapado à execução da pena, se a Parte requerida considerar que a prestação da cooperação pode comportar prejuízo à própria soberania, segurança ou a outros interesses nacionais essenciais.

O Acordo de Assistência Judiciária em Matéria Penal entre o Governo da República Federativa do Brasil e o Governo dos Estados Unidos da América foi promulgado pelo Decreto n. 3.810, de 2 de maio de 2001 e tem por objetivo facilitar a execução das tarefas das autoridades responsáveis pelo cumprimento da lei de ambos os países, na investigação, inquérito, ação penal e prevenção do crime por meio de cooperação e assistência judiciária mútua em matéria penal, tendo seu término por denúncia. Sobre a exigência da dupla incriminação, a assistência será prestada ainda que o fato sujeito à investigação não seja punível na legislação de ambos os Estados. Não há menção especifica a cartéis e/ou à área de 
defesa da concorrência, sendo que as Partes reconhecem a especial importância de combater graves atividades criminais, incluindo lavagem de dinheiro e trafico ilícitos de armas de fogo, munições e explosivos, sem limitar o alcance da assistência prevista neste artigo as Partes devem prestar assistência mutua sobre essas atividades. Dispõe sobre forma e conteúdo das solicitações. Tem por alcance a prestação de assistência mútua, nos termos do presente Acordo em matéria de investigação, inquérito, ação penal e prevenção do crime e processos relacionados de natureza criminal. A assistência inclui, entre outros, o fornecimento de documentos; tomada de depoimentos ou declarações de pessoas; localização ou identificação de pessoas (físicas ou jurídicas) ou bens; execução de pedidos de busca e apreensão; e qualquer outra forma de assistência não proibida pelas leis do Estado Requerido. Prevê as seguintes limitações: A Autoridade Central do Estado Requerido poderá negar assistência, entre outros, se a solicitação referir-se a delito previsto na legislação militar, sem contudo, constituir crime comum; se o atendimento à solicitação prejudicar a segurança ou interesses essenciais semelhantes do Estado Requerido; ou se a solicitação não for feita de conformidade com o Acordo.

O Acordo de Cooperação Judiciária e Assistência Mútua em Matéria Penal entre o Governo da República Federativa do Brasil e o Governo da República da Colômbia foi promulgado pelo Decreto n. 3.895, de 23 de agosto de 2001, tendo por objetivo incrementar ações conjuntas de prevenção, controle e repressão ao delito em todas as suas manifestações, por meio da coordenação de ações e execução de programas concretos. Tem seu término por denúncia. Não há a exigência da dupla incriminação, a assistência será prestada ainda que o fato sujeito à investigação não seja punível na legislação de ambos os Estados. Não há menção específica a cartéis e/ou à área de defesa da concorrência e dispõe sobre forma e conteúdo das solicitações. Tem por alcance a prestação de assistência mútua, conforme as disposições do acordo e em estrito cumprimento de seus respectivos ordenamentos jurídicos, para a investigação de delitos e a cooperação em processos relacionados à matéria penal. A assistência inclui, entre outros, notificação de atos processuais, recepção e produção prática de provas, tais como testemunhos e declarações, perícia e inspeção de pessoas, bens e lugares, localização e identificação de pessoas, traslado de pessoas detidas para efeito de 
comparecimento como testemunho no território da Parte Requerente ou com outros propósitos expressamente indicados no pedido, medidas cautelares sobre bens, entrega de documentos e de outros objetos de prova, embargo e sequestro de bens para efeitos de pagamento de indenizações e multas impostas por sentença penal. Por outro lado, tem as seguintes limitações: A Parte Requerida poderá denegar assistência quando, entre outros, se o pedido referir-se a delito previsto na legislação militar, mas não na legislação penal ordinária, a delito político ou conexo e realizado com fins políticos, à pessoa com relação à qual se solicita a medida haja sido absolvida ou haja cumprido pena na Parte Requerida pelo delito mencionado no pedido, quando o cumprimento do pedido seja contrário à segurança, à ordem pública ou a outros interesses essenciais da Parte Requerida e na situação que o pedido for contrário ao ordenamento jurídico da Parte Requerida.

O Acordo de Assistência Jurídica em Matéria Penal entre o Governo da República Federativa do Brasil e o Governo da República do Peru foi promulgado pelo Decreto n. 3.988, de 29 de outubro de 2001, tendo seu término por denúncia. Tem por objetivo desenvolver ações conjuntas de prevenção, controle e sanção do delito sob todas as suas formas, através da coordenação e execução de programas concretos, e de agilizar os mecanismos de assistência jurídica. Não há a exigência da dupla incriminação, a assistência será prestada mesmo quando o fato que lhe der motivo na Parte requerente não constitua delito na Parte requerida. Para a execução de mandados de busca de pessoas e registros, confiscos, indisponibilidade de bens, de sequestro com fim de prova e interceptação telefônica por ordem judicial devidamente motivada, assim como para a execução de medidas que envolvam algum tipo de coerção, a assistência somente será prestada se o fato lhe der motivo na Parte requerente estiver previsto como delito na legislação da Parte requerida ou quando a pessoa envolvida no pedido de assistência tiver manifestado livremente seu consentimento de forma escrita. Não há menção específica a cartéis e/ou à área de defesa da concorrência nem disposição sobre forma e conteúdo das solicitações. As Partes se comprometem a prestar, de acordo com sua legislação, assistência mútua em matéria de intercâmbio de informação, provas, processamento e demais procedimentos penais e compreenderá, entre outros, a localização e identificação de pessoas e bens, notificação de atos judiciais, entrega de documentos e informações judiciais. Não prevê 
expressamente nenhuma limitação à assistência, exceto para as circunstâncias especiais em que se exige a dupla incriminação para a assistência ser prestada.

O Tratado entre a República Federativa do Brasil e a República da Coréia sobre Assistência Jurídica Mútua em Matéria Penal foi promulgado pelo Decreto no 5.721 , de 13 de março de 2006 tendo seu término por denúncia. Tem por objetivo melhorar a eficácia da lei de ambos os países, na investigação, ação penal e prevenção do crime por meio de cooperação e assistência mútua em matéria penal. A assistência poderá ser denegada se, no entendimento da Parte Requerida, a conduta objeto da investigação, ação ou processo penal na Parte Requerente não constituir um delito nos termos da lei da Parte Requerida. Não há menção a cartéis e/ou à área de defesa da concorrência, as partes comprometeram-se a prestar mutuamente informações em matéria jurídica nas áreas abrangidas pelo Tratado, mas podem prestarem-se assistência nos termos de qualquer acordo, ajuste ou outra prática bilateral cabível. Dispõe sobre forma e conteúdo das solicitações. As Partes se obrigam a prestar assistência mútua nos termos do presente Acordo, da forma mais ampla possível em matéria de investigação, ação penal ou processos relacionados a delitos de natureza criminal e incluirá: tomada de depoimentos ou declarações de pessoas, fornecimento de informações, documentos, registros e elementos de prova, localização ou identificação de pessoas (físicas e jurídicas) ou bens, entrega de documentos, execução de pedidos de busca e apreensão, transferência de pessoas sob custódia para prestar depoimento ou ajudar nas investigações, etc. Tem por limitações que o Acordo não se aplica à extradição de qualquer pessoa, à execução, na Parte Requerida, de um julgamento criminal realizado na Parte Requerente, exceto na medida em que seja permitido pelas leis da Parte Requerida e neste Acordo, transferência de pessoas condenadas para cumprimento de sentença e transferência de procedimentos em matéria criminal. A assistência poderá ser denegada se a solicitação referir-se a delito político ou crime previsto na legislação militar sem, contudo, constituir crime comum; o cumprimento do pedido ofender a soberania, segurança, ordem pública ou qualquer outro interesse público essencial da Parte Requerida, entre outros. 
O Acordo de Assistência Judiciária em Matéria Penal entre a República Federativa do Brasil e a Ucrânia foi promulgado pelo Decreto n. 5.984 de 12 de dezembro de 2006 e tem por objetivo: melhorar a efetividade das autoridades responsáveis pelo cumprimento da lei de ambos os países, na investigação, inquérito e prevenção do crime por meio de cooperação e assistência jurídica mútua em matéria penal. Tem seu término por denúncia. Não há a exigência da dupla incriminação, a assistência será prestada ainda que a conduta sujeita a investigação, inquérito ou ação penal não seja punível nos termos da legislação de ambas as Partes. Embora não haja menção especifica a cartéis e/ou à área de defesa da concorrência, as Partes poderão, ainda, prestar assistência nos termos de qualquer tratado, acordo ou outra prática que possam ser aplicáveis entre os órgãos de cumprimento da lei das Partes. Há disposiçõos especificas sobre forma e conteúdo das solicitações. As Partes prestarão uma à outra assistência jurídica mútua, nos dispositivos do presente Tratado, em relação à investigação, inquérito e prevenção de crimes e processos relacionados à matéria penal, dentro dos limites de suas legislações e incluirá, entre outros, tomada de depoimentos; fornecimento de documentos e outros materiais de prova; entrega de documentos judiciais ou de outra natureza;localização ou identificação de pessoas ou objetos; transferência de pessoas sob custódia; execução de pedidos de busca e apreensão; identificação, rastreamento, indisponibilidade, sequestro, confisco e disposição de produtos do crime e assistência em processos relacionados; devolução de ativos, de acordo com a legislação interna. Como limitações, o Tratado não se aplica nos seguintes casos: busca, prisão ou encarceramento de pessoa processada ou julgada criminalmente com a intenção de obter-se a extradição da pessoa; execução de sentenças penais. A assistência também poderá ser denegada quando, entre outros, a solicitação referir-se a delito político ou a delito previsto na legislação militar, sem, entretanto, constituir crime comum; o atendimento à solicitação prejudicar sua soberania, segurança, ordem pública ou outros interesses públicos essenciais; a Parte Requerida já tiver proferido julgamento ou decisão final sobre a mesma pessoa pelo mesmo delito referido na solicitação.

O Acordo de Assistência Jurídica Mútua em Matéria Penal entre o Governo da República Federativa do Brasil e o Governo da República Popular da China foi promulgado 
pelo Decreto n. 6.282, de 3 de dezembro de 2007, tendo por objetivo: promover cooperação efetiva entre os dois países acerca de assistência judiciária mútua em material penal com base em respeito mútuo pela soberania e igualdade e benefício mútuo. Tem seu término por denúncia. As Partes podem recusar-se a prestar assistência judiciária mútua de acordo com este Artigo com base na ausência de dupla incriminação. Entretanto, quando julgar apropriado, a Parte Requerida pode decidir fornecer assistência de forma discricionária independentemente da conduta constituir-se ou não em ofensa sob a lei interna do Estado Requerido. Não há menção especifica a cartéis e/ou à área de defesa da concorrência, mas sim sobre forma e conteúdo das solicitações. As Partes se obrigam a prestar assistência mútua, nos termos do presente Tratado, em matéria de investigação, inquérito, ação penal e processos relacionados a delitos de natureza criminal. A assistência inclui, entre outros, a entrega de documentos; tomada de depoimentos ou declarações de pessoas; obtenção e fornecimento de avaliação por peritos; fornecimento de documentos, registros, e meios de prova, inclusive registros bancários, financeiros, corporativos ou empresariais; localização ou identificação de pessoas, ativos ou meios de prova; condução de inspeção judicial ou exame de locais e objetos; e qualquer outra forma de assistência não proibida pelas leis do Estado Requerido. Como limitações, prevê que: O Estado Requerido poderá negar assistência se a solicitação referir-se a delito militar ou a delito político; prejudicar sua soberania, segurança, ordem pública ou outros interesses essenciais; a Parte Requerida já tiver dado julgamento ou decisão final sobre a mesma pessoa pelo mesmo delito relacionado na solicitação; existirem motivos substanciais para a Parte Requerida acreditar que a solicitação foi feita com intuito de investigar, processar, punir ou proceder de qualquer outra forma contra uma pessoa por causa de sua raça, sexo, religião, nacionalidade ou opinião política, ou que a posição daquela pessoa possa ser prejudicada por qualquer daquelas razões;ou a solicitação não for feita de conformidade com este Tratado.

O Acordo de Cooperação Judicial em Matéria Penal entre o Governo da República Federativa do Brasil e o Governo da República de Cuba foi promulgado pelo Decreto n. 6.462, de 21 de maio de 2008, tendo por objetivo melhorar a eficiência de ambos os países na prevenção, investigação, ação penal e combate ao crime por meio de cooperação judicial 
mútua em matéria penal. Tem seu término por denúncia. Os pedidos de assistência poderão ser recusados se os fatos ou omissões alegados que deram origem à solicitação não constituírem um delito previsto na legislação da Parte Requerida. Não há menção especifica a cartéis e/ou à área de defesa da concorrência, e dispõe sobre forma e conteúdo das solicitações. Tem por alcance que as Partes cooperarão entre si adotando todas as medidas apropriadas de que dispõem, a fim de prestar cooperação em matéria penal, nos termos do presente Acordo e dentro dos limites das disposições dos respectivos ordenamentos jurídicos internos. Enquanto limitações, o acordo não faculta às autoridades de uma das Partes a, na jurisdição territorial da outra, exercerem ou desempenharem funções cuja jurisdição ou competência estejam exclusivamente reservadas às autoridades da outra Parte, de acordo com suas leis ou regulamentos nacionais. Também, a cooperação será denegada se, conforme juízo da Parte Requerida, entre outros, se a execução do pedido afetar sua soberania, segurança, ordem pública ou interesses públicos essenciais similares, prejudicar a segurança de qualquer pessoa ou não for razoável por outros motivos. Por fim, a Parte Requerente não usará a informação ou as provas obtidas no âmbito do presente Acordo para propósitos diferentes daqueles constantes do pedido, sem o consentimento prévio da Autoridade Central da Parte Requerida.

O Acordo de Cooperação e Auxílio Jurídico Mútuo em Matéria Penal entre a República Federativa do Brasil e o Reino da Espanha foi promulgado pelo Decreto ${ }^{\circ} 6.681$, de 8 de dezembro de 2008, tendo por objetivo: promover ações de controle e repressão de delitos em todas as suas manifestações por meio da coordenação de ações e execução de programas concretos. Tem seu término por denúncia e não há exigência da dupla incriminação: o auxílio será prestado mesmo que o fato pelo qual se processa na Parte requerente não seja considerado delito pelo ordenamento jurídico da Parte requerida. Não há menção especifica a cartéis e/ou à área de defesa da concorrência, e dispõe sobre forma e conteúdo das solicitações. Sobre o alcance, as Partes se comprometem a prestar mutuamente, segundo as disposições do presente Acordo, o auxílio jurídico mais amplo possível em todos os procedimentos referentes a delitos cuja repressão seja, no momento em que se solicita o auxílio, da competência das autoridades judiciais ou do Ministério Público da Parte requerente. Por outro lado, prevê as seguintes limitações, (i) não faculta às autoridades ou aos 
particulares da Parte requerente realizar no território da Parte requerida atividades que, segundo as leis internas, estejam reservadas a suas autoridades, (ii) em casos, por exemplo, de o pedido se referir a delitos tipificados na Parte requerida como exclusivamente militares; políticos ou a eles conexos, e, ainda, (iii) Parte requerida poderá denegar auxílio caso considere que o pedido ofende a soberania, a segurança, a ordem pública ou outros interesses essenciais de seu país.

O Tratado de Assistência Mútua em Matéria Penal entre o Governo da República Federativa do Brasil e o Governo do Canadá foi promulgado pelo Decreto n. 6.747, de 22 de janeiro de 2009, tendo por objetivo: tornar mais efetivas as ações dos dois países na investigação, processo penal e repressão do crime mediante cooperação e assistência mútua em matéria penal. Tem seu término por denúncia. Não há dispositivo especifico sobre a exigência da dupla incriminação nem faz menção a cartéis e/ou à área de defesa da concorrência. Dispõe sobre forma e conteúdo das solicitações. Tem por alcance a prestação de assistência mútua em matéria penal na medida mais ampla possível e incluirá, entre outros, tomada de depoimentos e obtenção de declarações de pessoas; fornecimento de informações, documentos e outros registros, inclusive registros criminais, registros judiciais e registros governamentais; localização de pessoas e objetos, inclusive a identificação dos mesmos; busca e apreensão; entrega de bens, inclusive empréstimo de provas materiais; tornar disponíveis pessoas detidas e outras para fornecer provas ou auxiliar investigações; transmissão de documentos, inclusive documentos visando ao comparecimento de pessoas em juízo; medidas para localizar, bloquear e confiscar produtos oriundos de crime. Tem por limitação à prestação dessa assistência, quando, na opinião do Estado requerido, sua execução puder de alguma maneira afetar sua soberania, segurança, ordem pública ou interesse público essencial semelhante, prejudicar a segurança de qualquer pessoa ou não ser razoável por outras razões.

O Tratado entre o Governo da República Federativa do Brasil e o Governo da República do Suriname sobre Assistência Jurídica Mútua em Matéria Penal foi promulgado pelo Decreto $\mathrm{n}^{\mathrm{o}}$ 6.832, de 29 de abril de 2009, tendo por objetivo melhorar a efetividade das autoridades responsáveis pelo cumprimento da lei de ambos os países, na investigação, 
inquérito e prevenção do crime por meio de cooperação e assistência jurídica mútua em matéria penal. Tem seu término por denúncia. Não há a exigência da dupla incriminação, sendo que assistência será prestada ainda que a conduta sujeita a investigação, inquérito ou ação penal não seja punível nos termos da legislação de ambas as Partes. Embora não haja menção a cartéis e/ou à área de defesa da concorrência, prevê que as Partes poderão prestar assistência nos termos de qualquer tratado, acordo ou outra prática que possam ser aplicáveis entre os órgãos de cumprimento da lei das Partes. Dispõe sobre forma e conteúdo das solicitações. Tem por alcance, a prestação de assistência jurídica mútua em relação à investigação, inquérito e prevenção de crimes e processos relacionados à matéria penal, dentro dos limites de suas legislações e incluirá, entre outros, tomada de depoimentos; fornecimento de documentos e outros materiais de prova; entrega de documentos judiciais ou de outra natureza; localização ou identificação de pessoas ou objetos; transferência de pessoas sob custódia; execução de pedidos de busca e apreensão; identificação, rastreamento, indisponibilidade, sequestro, confisco e disposição de produtos do crime e assistência em processos relacionados; devolução de ativos, de acordo com a legislação interna. Enquanto limitações dessa assistência, o Tratado não se aplica nos seguintes casos: busca, prisão ou encarceramento de pessoa processada ou julgada criminalmente com a intenção de obter-se a extradição da pessoa; execução de sentenças penais. A assistência também poderá ser denegada quando, entre outros, a solicitação referir-se a delito político ou a delito previsto na legislação militar, sem, entretanto, constituir crime comum; o atendimento à solicitação prejudicar sua soberania, segurança, ordem pública ou outros interesses públicos essenciais; a Parte Requerida já tiver proferido julgamento ou decisão final sobre a mesma pessoa pelo mesmo delito referido na solicitação.

O Tratado de Cooperação Jurídica em Matéria Penal entre a República Federativa do Brasil e a Confederação Suíça foi promulgado pelo Decreto no 6.681 , de 8 de dezembro de 2008, tendo por objetivo concluir um Tratado de cooperação jurídica em matéria penal e de cooperar de forma mais eficiente na investigação, persecução e repressão de delitos. Tem seu término por denúncia. Não há dispositivo regendo a matéria da exigência da dupla incriminação, tampouco sobre a aplicação especifica em caso de cartéis e/ou à área de defesa 
da concorrência. Dispõe sobre forma e conteúdo das solicitações. Tem por alcance a mis ampla cooperação jurídica em qualquer investigação relativos a delitos cuja repressão é da jurisdição do Estado Requerente e abrange, entre outros, tomada de depoimentos ou outras declarações; entrega de documentos, registros e elementos de prova, inclusive os de natureza administrativa, bancária, financeira, comercial e societária; restituição de bens e valores; troca de informações; busca pessoal e domiciliar; busca \& apreensão, sequestro e confisco de produtos de delito; intimação de atos processuais; transferência temporária de pessoas detidas para fins de audiência ou acareação. Enquanto limitações, o Tratado não se aplica aos seguintes casos: busca, detenção ou prisão de uma pessoa processada ou julgada penalmente com o intuito de obter a sua extradição e execução de sentenças penais sendo que a cooperação jurídica poderá ser recusada se, entre outros, o pedido de cooperação se referir a infrações consideradas pelo Estado Requerido como delitos políticos ou conexos a delitos políticos; se o pedido referir-se a delitos militares que não constituam delitos de direito comum; se o Estado Requerido julgar que a execução do pedido pode atentar contra a sua soberania.

\subsection{Acordos de Extradição}

Os Tratados de Extradição são acordos bilaterais que permitem que um signatário requeira a transferência para si de um indivíduo localizado na jurisdição do outro signatário com o propósito de persecução penal. O ex-ministro do Supremo Tribunal Federal, Francisco Rezek (2005), conceitua extradição como:

Entrega, por um Estado a outro, e a pedido deste, de pessoa que em seu território deva responder a processo penal ou cumprir pena. Cuida-se de uma relação executiva, com envolvimento judiciário de ambos os lados: o governo requerente da extradição só toma essa iniciativa em razão da existência do processo penal - findo ou em curso - ante sua Justiça; e o governo do Estado requerido (...) não goza, em 
geral, de uma prerrogativa de decidir sobre o atendimento do pedido senão depois de um pronunciamento da Justiça local.

Para Rodrigues (1930, p.3), o ato de extraditar consiste em

ato de vontade soberana de um Estado que entrega à justiça repressiva de outro Estado um indivíduo, por este perseguido e reclamado, como acusado ou já condenado por determinado fato sujeito à aplicação da lei penal.

\begin{abstract}
Ainda que tratados de extradição não sejam instrumentos cooperacionais específicos do Direito Antitruste, preenchidos certos requisitos, podem ser usados pelas autoridades brasileiras de defesa da concorrência em conexão com as investigações de cartéis internacionais. Tais requisitos integram o sistema "da contenciosidade limitada", adotado pelo Brasil, que investe o Supremo Tribunal Federal na categoria de órgão juridicamente existente apenas no âmbito do direito interno, devendo, portanto, adstringir-se a examinar a legalidade da extradição; é dizer, seus aspectos formais, nos termos do art. 83 da Lei 6.815/80:
\end{abstract}

Nenhuma extradição será concedida sem prévio pronunciamento do Plenário do Supremo Tribunal Federal sobre sua legalidade e procedência, não cabendo recurso da decisão.

A despeito da existência de determinado acordo bilateral cooperacional, seja de primeira ou segunda geração seja de cooperação judiciária e assistência mútua em matéria penal, na busca de assistência técnica em matéria antitruste, as autoridades brasileiras de defesa da concorrência pode também requerer ou prover assistência recíproca ao amparo dos tratados de extradição.

Os tratados de extradição só poderão ser aplicados para fins de cooperação antitruste nas situações em que ambas as jurisdições definirem em seus ordenamentos jurídicos a possibilidade do individuo ser criminalmente perseguido pela prática de cartel. São 
assim, norteados pelo princípio da dupla incriminação, o qual que se legitima na necessidade de o crime assim ser considerado tanto no país que requer a extradição de um indivíduo como no Estado requerido. Sua interpretação traduz-se na garantia de não infringência ao princípio da legalidade, ou seja, de que não pode haver um crime se não houver previsão legal assim o definindo. No caso dos pedidos de extradição, estes não se restringem, porém, à existência de previsão de tipos legais idênticos, mas também se a ação é típica e antijurídica nos dois ordenamentos jurídicos, excluindo-se, daí, os delitos de natureza militar ou política. Outro princípio fundamental é o do non bis in idem, ou seja, a proibição da concessão do pedido ante a hipótese de já existir sentença condenatória transitada em julgado pelo mesmo crime em que se solicita a extradição.

O Brasil tem tratados bilaterais de extradição com Argentina, Austrália, Bélgica, Bolívia, Chile, Colômbia, República da Coréia, Equador, Espanha, França, Estados Unidos da América, Itália, Lituânia, México, Paraguai, Peru, Portugal, Reino Unido, Romênia, Rússia, Suíça, Ucrânia, Uruguai e Venezuela. Há também um tratado multilateral extradicional celebrado entre os países do MERCOSUL ${ }^{140}$ e países associados (Bolívia e Chile), que já foi ratificado pelo Brasil por meio do Decreto $n^{\circ} 35$ de 2002; porém, para ter vigência internacional, é necessária a ratificação de pelo menos dois países membros do Mercosul e um país associado.

Tramitam no Congresso Nacional os tratados bilaterais de extradição com os seguintes países: Angola, Canadá, Guatemala, Líbano, Moçambique, Panamá, República Dominicana e Suriname.

\footnotetext{
${ }^{140}$ Até a presente data, apenas o Brasil e o Uruguai ratificaram o Acordo. Cf. última atualização do site da Organização dos Estados Americanos aconteceu em maio de 2010, recuperado em 26 de junho de 2010, em: http://www.oas.org/juridico/mla/pt/bra/index.html.
} 


\section{Avaliação dos acordos}

\subsection{Acordos de Primeira Geração}

Todos os oito acordos descritos no Item 1.1. acima, de forma pormenorizada, fazem parte dos chamados acordos de primeira geração e objetivam fundamentalmente desenvolver uma cooperação na área da política de concorrência entre seus signatários nos casos de interesse mútuo da aplicação das leis de defesa da concorrência, da cortesia positiva.

A análise aprofundada de todos acordos demonstra que inexiste dispositivo nesses acordos que permita o intercâmbio de informações confidenciais entre as agências de defesa da concorrência.

Nota-se também, a partir da análise dos instrumentos, que, ao tempo em que as partes se comprometem a compartilhar informações entre si, também reconhecem que é a lei do direito interno de cada uma que rege esse compromisso. Assim, nos termos desse compromisso, normalmente, as informações e documentos trocados entre as agências referemse a materiais publicamente disponíveis. Sabe-se que as leis nacionais sobre informações confidenciais abrangem uma série de categorias, tais como, segredo judicial, segredo de negócio, informação pessoal. Tendem, assim, a expressamente proibirem a publicação ou divulgação de tais informações com vistas a salvaguardar os direitos de privacidade dos indivíduos e garantir que informações sensíveis do ponto de vista dos negócios das empresas não sejam divulgadas por alguma agência do governo. Desta forma, no âmbito da cooperação internacional com as outras agências de defesa da concorrência, está o SBDC restrito a obedecer às garantias da confidencialidade tal como exigida pelas legislações brasileiras ou ainda podem os órgãos brasileiros compartilhar informações confidenciais quando autorizado expressamente pela parte cuja informação confidencial está se pretendendo compartilhar. 
Outro ponto importante de se ressaltar diz respeito à obtenção de evidências localizadas no estrangeiro. Por exemplo, que as agências de defesa da concorrência possam, a partir da concessão de mandado judicial, proceder com medidas de busca e apreensão ${ }^{141}$ de documentos para fins de melhor instruir suas investigações além de estarem dotadas de outros poderes de investigação ${ }^{142}$ com vistas à obtenção de material probatório. Como tais poderes investigativos estão devidamente fundamentados e legitimados na legislação brasileira, tendo sido concedidos às agências nacionais de defesa da concorrência, agências internacionais não estão autorizadas a exercerem tais medidas de investigação no Brasil.

Conforme aponta o quadro descritivo, os acordos do Brasil possuem conteúdo bastante generalista. Suas disposições preveem mecanismos da cooperação em matéria antitruste $^{143}$, tendo normalmente, por objeto, a troca de experiências e treinamentos entre as partes, o intercâmbio livre de informações não confidenciais ${ }^{144}$, a mútua promoção

\footnotetext{
${ }^{141}$ Nos termos do artigo 13 da Lei Antitruste: “Art. 13. Compete à Superintendência-Geral: (...) d - requerer ao Poder Judiciário, por meio da Procuradoria Federal junto ao Cade, mandado de busca e apreensão de objetos, papéis de qualquer natureza, assim como de livros comerciais, computadores e arquivos magnéticos de empresa ou pessoa física, no interesse de inquérito administrativo ou de processo administrativo para imposição de sanções administrativas por infrações à ordem econômica, aplicando-se, no que couber, o disposto no art. $839 \mathrm{e}$ seguintes da Lei n. 5.869, de 11 de janeiro de 1973 - Código de Processo Civil, sendo inexigível a propositura de ação principal".

${ }^{142}$ Nos termos do artigo 13 da Lei Antitruste: “Art. 13. Compete à Superintendência-Geral: a) requisitar informações e documentos de quaisquer pessoas, físicas ou jurídicas, órgãos, autoridades e entidades, públicas ou privadas, mantendo o sigilo legal, quando for o caso, bem como determinar as diligências que se fizerem necessárias ao exercício de suas funções; b) requisitar esclarecimentos orais de quaisquer pessoas, físicas ou jurídicas, órgãos, autoridades e entidades, públicas ou privadas, na forma desta Lei; c) realizar inspeção na sede social, estabelecimento, escritório, filial ou sucursal de empresa investigada, de estoques, objetos, papéis de qualquer natureza, assim como livros comerciais, computadores e arquivos eletrônicos, podendo-se extrair ou requisitar cópias de quaisquer documentos ou dados eletrônicos; (...)”.

${ }^{143}$ À exceção do Acordo entre Estados Unidos e Canadá, também aplicável à cooperação em relação à proteção e defesa do consumidor.

${ }^{144}$ Tais como legislações, publicações e decisões ou outras informações também públicas relacionadas aos atos de concentração e práticas anticompetitivas transnacionais. As informações confidencias somente podem ser compartilhadas se permitido expressamente pela parte detentora da informação, o que, no geral, vem acompanhado de uma série de limitações. Cf. Martinez (2005).
} 
institucional e cultural em prol da defesa da concorrência, notificação das investigações e atos de concentração que possam ter efeitos em ambos os Estados etc.

Menciona-se que os acordos de primeira geração assinados pelo Brasil são todos baseados no princípio da cortesia positiva pelo qual uma parte deve considerar os interesses da outra quando da sua aplicação das leis de defesa da concorrência em seu território.

Outra característica identificada é que tais instrumentos incluem compromissos de coordenação e notificação que estabelecem o tipo, as circunstâncias e procedimentos para a troca das informações relevantes. Em geral, é o direito interno de cada parte que delimita e define tais critérios. Assim, os compromissos de coordenação e notificação, tal como aquele de cooperação, estão sujeitos às leis internas das partes, sendo certo que não prevalecerão em caso de conflito ou dissonância com elas.

A despeito desses acordos assinados pelo Brasil serem de primeira geração, Araújo (2006) esclarece que eles oferecem evidentes vantagens tanto em relação aos instrumentos de soft law quanto à cooperação informal, uma vez que fornecem aos Estados uma moldura mais clara sobre o escopo da cooperação. Da mesma forma, na medida em que os compromissos neles assumidos instituem relações mais sólidas entre as agências e representam um desejo de aprofundamento de tais laços, refletem um anseio compartilhado entre as agências em prover assistência uma a outra na extensão do quanto permitido pela legislação nacional.

\subsection{Acordos de Cooperação Judiciária e Assistência Mútua em Matéria Penal}

Os 14 acordos bilaterais desta natureza assinados pelo Brasil dispõem, em termos gerais, de dispositivos que regulem os meios de produção de provas e de acesso às evidências que estejam localizadas no outro país e que sejam importantes para as investigações criminais do país que busca a assistência. Tais acordos possuem natureza de Tratados Internacionais, 
sendo sempre (i) celebrados pelo Presidente da República em nome da República Federativa do Brasil, conforme artigo 84, inciso VIII ${ }^{145}$, da Constituição Federal Brasileira (BRASIL, 1988), (ii) aprovados pelo Congresso Nacional por meio de Decretos Legislativos, conforme artigo 49, inciso $\mathrm{I}^{146}$, da Constituição Federal Brasileira e (iii) promulgados pelo Presidente da República por decreto conforme artigo 84, inciso IV $^{147}$, da Constituição Federal Brasileira. São, assim, incorporados no ordenamento jurídico brasileiro e, em consequência, possuem força obrigatória, ou seja, geram direitos e obrigações para seus signatários. É de se notar que, para o Supremo Tribunal Federal, os tratados internacionais, mesmo aqueles que abordam matéria relativa a direitos humanos, são incorporados ao direito brasileiro como norma ordinária, ou seja, serão equiparados às leis ordinárias, conforme entendimento exposto pela Suprema Corte ${ }^{148}$. Em suma, referido entendimento estabelece a prevalência da Constituição Brasileira sobre quaisquer convenções internacionais.

145 Art. 84. "Compete privativamente ao Presidente da República: (...) VIII - celebrar tratados, convenções e atos internacionais, sujeitos a referendo do Congresso Nacional; (...)".

146 Art. 49. "É da competência exclusiva do Congresso Nacional: I - resolver definitivamente sobre tratados, acordos ou atos internacionais que acarretem encargos ou compromissos gravosos ao patrimônio nacional;(...)".

147 Art. 84. "Compete privativamente ao Presidente da República: (...) IV - sancionar, promulgar e fazer publicar as leis, bem como expedir decretos e regulamentos para sua fiel execução;(...)”.

148 "Prevalência da Constituição, no Direito brasileiro, sobre quaisquer convenções internacionais, incluídas as de proteção aos direitos humanos, que impede, no caso, a pretendida aplicação da norma do Pacto de São José: motivação. A Constituição do Brasil e as convenções internacionais de proteção aos direitos humanos: prevalência da Constituição que afasta a aplicabilidade das cláusulas convencionais antinômicas. (...) Assim como não o afirma em relação às leis, a Constituição não precisou dizer-se sobreposta aos tratados: a hierarquia está ínsita em preceitos inequívocos seus, como os que submetem a aprovação e a promulgação das convenções ao processo legislativo ditado pela Constituição e menos exigente que o das emendas a ela e aquele que, em consequência, explicitamente admite o controle da constitucionalidade dos tratados (CF, art. 102, III, ). Alinharse ao consenso em torno da estatura infraconstitucional, na ordem positiva brasileira, dos tratados a ela incorporados, não implica assumir compromisso de logo com o entendimento majoritário em recente decisão do STF (ADI 1.480-MC) que, mesmo em relação às convenções internacionais de proteção de direitos fundamentais, preserva a jurisprudência que a todos equipara hierarquicamente às leis ordinárias. Em relação ao ordenamento pátrio, de qualquer sorte, para dar a eficácia pretendida à cláusula do Pacto de São José, de garantia do duplo grau 
Tais acordos criam, assim, obrigações internacionais vinculativas entre os signatários. O Brasil assinou seu primeiro “Acordo de Cooperação Judiciária e Assistência Mútua em Matéria Penal" em 1993 com a Itália e, desde então, mais 13 acordos desta natureza foram assinados. Como referência, os Estados Unidos da América possuem pouco mais de 55 acordos dessa natureza $^{149}$.

Nos termos de tais acordos, a assistência é solicitada e prestada somente para a matéria conexa a assuntos criminais e embora nenhum deles disponha especificamente de previsão para aplicação a assuntos do Direito Antitruste, podem ser aplicados nas investigações de cartéis internacionais já que tais condutas além de constituírem ofensa administrativa do ponto de vista da lei de defesa da concorrência, configuram-se também crimes. De que se tem notícia, no entanto, nenhum desses acordos teve tal aplicação.

Outra característica desses acordos é que nem todos possuem o requisito da dupla incriminação, ou seja, não é sempre imprescindível que a assistência solicitada e prestada esteja relacionada a um crime, assim previsto na legislação interna da parte requerida, como no caso dos acordos com a Itália, Estados Unidos da América, Colômbia, Peru, Espanha e Suriname.

Também é de importância notar que, normalmente, o alcance da assistência é bastante amplo incluindo medidas de instrução e investigação tais como, a tomada de depoimentos e de declarações pessoais; fornecimento de documentos e outros materiais de

de jurisdição, não bastaria sequer lhe conceder o poder de aditar a Constituição, acrescentando-lhe limitação oponível à lei como é a tendência do relator: mais que isso, seria necessário emprestar à norma convencional força ab-rogante da Constituição mesma, quando não dinamitadoras do seu sistema, o que não é de admitir". (BRASIL, 2002)

149 Argentina, Antígua e Barbuda, Áustria, Austrália, Barbados, Bahamas, Belize, Brasil, Bélgica, Canadá, Colômbia, Chipre, República Dominicana, República Checa, Estônia, Egito, Finlândia, Hong Kong, França, Grenada, Grécia, Índia, Hungria, Itália, Israel, Japão, Jamaica, Coreia, Lituânia, Luxemburgo, Letônia, Principado de Liechtenstein, Marrocos, México, Filipinas, Países Baixos, Panamá, Romênia, Polônia, St. Kitts \& Nevis, Espanha, África do Sul, St. Lucia, Suíça, Saint Vincent \& the Grenadines, Trindade e Tobago, Turquia, Tailândia, Reino Unido, Anguilla, Ilhas Virgens Britânicas, Ilhas Caymans, Turks and Caicos Islands, Uruguai, Ucrânia e Venezuela. Conforme informação disponível no site da Expat Intelligence, recuperado em 25 de junho de 2012, em: http://www.expatintelligence.com/mutual-legal-assistance-treaties.shtml. 
prova; localização ou identificação de pessoas ou objetos; transferência de pessoas sob custódia; execução de pedidos de busca e apreensão; condução de inspeção judicial ou exame de locais e objetos; identificação, rastreamento, indisponibilidade, sequestro, confisco e disposição de produtos do crime e assistência em processos relacionados, entre outras.

Da mesma forma, há casos em que a assistência poderá ser denegada, normalmente, quando seu pedido se referir a infrações consideradas pela parte requerida como delitos políticos ou conexos a delitos políticos; ou referir-se a delitos militares que não constituam delitos de direito comum; se a parte requerida julgar que a execução do pedido pode atentar contra a sua soberania, segurança, ordem pública ou outros interesses essenciais

\subsection{Acordos de Extradição}

Dos países com os quais o Brasil assinou tratado de extradição e aqueles que, assim como a legislação brasileira, perseguem criminalmente a conduta de cartel são Estados Unidos da América, Reino Unido, Canadá, Austrália, Japão, França, Chile, Coréia do Sul, Itália, México, Suíça. Assim, somente nestes, no âmbito dos tratados de extradição com tais países é que um indivíduo perseguido por cartel poderia ser objeto de uma solicitação extradicional.

No Brasil, o Ministério da Justiça, por meio da Secretaria Nacional de Justiça, é o responsável por formalizar os pedidos de extradição feitos por autoridades judiciárias brasileiras a um determinado Estado estrangeiro (ativa) ou, ainda, processar, opinar e encaminhar as solicitações de extradição formuladas por outro país às autoridades brasileiras (passiva). Os pedidos de extradição formulados ao Governo brasileiro são analisados pelo Supremo Tribunal Federal e da sua decisão não cabe recurso, apenas embargos de declaração. 


\section{A jurisprudência brasileira em termos de cooperação}

A análise da jurisprudência brasileira revela que os Estados Unidos e a Comissão Europeia tem sido os maiores cooperadores com o Brasil no combate a cartéis internacionais.

\subsection{O cartel internacional das lisinas}

As autoridades brasileiras de defesa da concorrência estrearam sua participação na cooperação com suas agências-irmãs estrangeiras em 1999, quando o então Secretário da SEAE, tendo participado de um workshop de Cartéis Internacionais em Washington DC, toma conhecimento dos detalhes da investigação do cartel internacional de lisinas levada a cabo pelo Departamento de Justiça dos Estados Unidos (ARAUJO, M. 2002). Foi instaurado o Processo Administrativo n. 08012.004897/2000-23 para verificar a participação das empresas brasileiras em referido cartel.

Em Nota Técnica final proferida pela antiga SDE em 18 de dezembro de 2009 a SDE concluiu que as Representadas (subsidiárias brasileiras das empresas americanas condenadas) "não são as pessoas jurídicas contra as quais a SDE reuniu indícios que poderiam motivar a condenação por infração à ordem econômica" sugerindo ao CADE o arquivamento do feito para as empresas brasileiras ressaltando que as empresas estrangeiras é que deveriam ter constado do polo passivo do processo tendo já havido a prescrição para instauração de novo processo contra elas uma vez que a época confessada para a existência de cartel foi junho de 1992 a junho de 1995. 
Ao final, o CADE determinou o arquivamento do feito, uma vez que reconheceu a incidência do instituto da prescrição intercorrente, em virtude da inércia da Administração Pública por período superior a três anos.

\subsection{O cartel internacional das vitaminas}

Tratou-se de processo administrativo n. 08012.004599/99-18 instaurado em 17 de maio de 2000 (BRASIL, 2007), por despacho do Senhor Secretário de Direito Econômico, publicado no Diário Oficial da União na mesma data, para apurar a existência de infrações à ordem econômica nacional, resultante da prática de cartel com atuação em âmbito internacional entre 1990 e 1999.

Conforme descrito pela Nota Técnica da $\mathrm{SDE}^{150}$, as investigações pelas autoridades antitruste brasileiras iniciaram-se com a promoção de Averiguação Preliminar, instaurada por despacho do então Secretário de Direito Econômico, de 26 de maio de 1999, após a veiculação de matérias nos jornais O Globo (fls. 02/03) e Gazeta Mercantil (fls. 04), informando acerca da condenação das empresas representadas pelo Departamento de Justiça dos Estados Unidos pela formação de cartel de dimensões internacionais no mercado de vitaminas.

As matérias jornalísticas noticiavam a aplicação de multa no valor de US\$ 500 milhões e US\$ 225 milhões, respectivamente, à empresa suíça Roche e à alemã Basf, pela participação no cartel, que resultou na fixação de preços e produção das vitaminas A, B2, B5,

${ }^{150}$ Nota Técnica 2005/SDE/DPDE/CGAJ, proferida em: 3 jun. 2005. 
C, E, betacaroteno e das pré-misturas. O grupo francês Rhône-Poulenc também estava envolvido no conluio lá deflagrado, mas por ter cooperado com aquelas investigações (Programa de Leniência do Departamento de Justiça dos Estados Unidos) não sofreu sanção pecuniária.

Vale mencionar que, quando da instauração do processo administrativo, a SDE determinou a juntada ex officio aos autos das decisões condenatórias pela prática de cartel internacional no mercado de vitaminas da Comissão de Concorrência das Comunidades Europeias e do Departamento de Justiça Norte-Americano. Tais decisões eram públicas e foram retiradas dos sites oficiais dessas autoridades, também sendo determinada pela SDE a tradução destes documentos. Além disso, o despacho determinava que fossem apresentadas informações acerca das exportações de vitaminas para o mercado brasileiro, bem como o faturamento líquido auferido com as vendas dessas vitaminas.

Sendo assim, com base em tais documentos, a SDE comprovou a existência de cartel internacional e o fato de que o Brasil havia sido afetado por tal conduta colusiva, tendo sugerido ao CADE a condenação das empresas e pessoas físicas envolvidas, tendo o Conselho, em abril de 2007, condenado algumas das empresas investigadas. O então Conselheiro Paulo de Azevedo Furquim, em seu voto-vista, delimitou os critérios probatórios para a condenação de um cartel internacional com efeitos no Brasil afirmando que nesses casos "basta provar que o Brasil faz parte do objeto do acordo de cartel." E complementou o ex-Conselheiro Luiz Tadeu Delorme Prado: "Portanto, aceita a tese pelos autores de que havia um cartel internacional e, ainda, havendo evidência que este tratava da exportação para várias regiões do mundo, inclusive às Américas, há indícios suficientes para concluir que este afetava também o Brasil"'.

\subsection{O suposto cartel entre 2001 e 2006 do LCD}


Recentemente, a cooperação novamente foi um importante instrumento para a autoridade antitruste brasileiro. Em 17 de dezembro de 2008 foi instaurada pela SDE a Averiguação Preliminar n. 08012.011980/208-12 para investigar suposto cartel internacional com efeitos no Brasil entre os fabricantes de transistores de película fina para painéis de cristal líquido (TFT-LCD), conhecido como Cartel do LCD. Nos termos na Nota Técnica de abertura do Processo Administrativo, datada de 07 de dezembro de 2009, o fundamento para instauração da investigação estava, entre outros, na notícia da celebração de acordo de confissão de prática de cartel entre 2001 e 2006 no mercado de transistores de película fina para painéis de cristal líquido (TFT-LCD) firmado pelas empresas Sharp Co. (Sharp), Chungwa Picture Tubes Ltd. (Chungwa), LG Display Co. (LG) e LG Display América, Inc., (LG EUA) e seus executivos, diante das autoridades de defesa da concorrência dos Estados Unidos da América. Conforme descreve a Nota Técnica o Departamento de Justiça dos Estados Unidos tornou público em 12 de novembro de 2008 que a Sharp, a Chunghwa, a LG e a LG EUA admitiram o envolvimento em um cartel destinado à fixação artificial de preços de TFT-LCD nos Estados Unidos e no resto do mundo. Também tornou público que as empresas se comprometeram a recolher US\$ 585 milhões (quinhentos e oitenta e cinco milhões de dólares americanos) em multas devidas pelas práticas das infrações nos Estados Unidos.

Descreve ainda a Nota Técnica que segundo os documentos oficiais norteamericanos publicamente disponíveis, LG, LG EUA, Chungwa e outros concorrentes no mercado de painéis de TFT-LCD encontravam-se nos chamados "crystal meetings" (reuniões de cristal). Durante esses encontros e outras discussões, as empresas envolvidas concordaram em fixar o preço dos painéis de TFT-LCD usados em monitores de computadores, laptops, TVs e outros produtos de LCD para consumidores em todos os países do mundo. Além disso, havia troca de informações comercialmente sensíveis como oferta, demanda e planos de expansão, com reuniões bilaterais e multilaterais. A Nota Técnica descreve ainda que o Departamento de Justiça dos Estados Unidos tornou públicas as confissões feitas por executivos e empresas pela prática de cartel internacional. 
Importa destacar, ainda, que a Nota Técnica da SDE noticia a existência de investigações na Coréia do Sul, Japão e Comissão Europeia, já tendo havido condenação pela autoridade japonesa. Com relação à prática no Brasil, ressalta a SDE que suas suspeitas foram as de que os representados, nos termos do já confessado perante as autoridades americanas, desenvolveram o cartel internacional no mercado de painéis de TFT-LCD por meio das seguintes condutas: (i) reuniões, conversas e comunicações em Taiwan, Coréia do Sul e Estados Unidos; (ii) ajuste de preços nestas reuniões e conversas; (iii) envio aos demandantes de orçamentos de acordo com o pré-ajustado com os outros concorrentes; (iv) trocas de dados relativos às vendas de painéis de TFT-LCD, com a finalidade de monitorar e obrigar a efetivação dos acordos entre concorrentes. Além disso, havia troca de informações comercialmente sensíveis como oferta, demanda e planos de expansão, com reuniões bilaterais e multilaterais, com a referência igualmente a acordos de divisão de clientes.

Com relação aos efeitos da suposta prática no Brasil, destacou a Nota Técnica da SDE que o mercado brasileiro é atendido integralmente por importações e destacou o entendimento firmado no cartel das vitaminas no que se refere aos efeitos do cartel, destacando se necessário apenas a análise de dois critérios, quais seja, a comprovação da formação de cartel em território estrangeiro; e uma jurisdição é afetada por um cartel - e, portanto, tal cartel deve ser objeto de punição nessa jurisdição - se a sua área de abrangência inclui, no todo ou em parte, o objeto do cartel, sendo irrelevante onde o acordo foi "celebrado" e importando apenas saber qual o espaço abrangido pelo acordo entre empresas.

Portanto, determinou a SDE a instauração de Processo Administrativo em 07 de dezembro de 2009 estando o processo atualmente sob instrução da SDE. Ainda que não haja decisão no Brasil sob tal suposto cartel, a cooperação mostrou-se essencial eis que o processo na jurisdição brasileira fundamentou-se principalmente nas informações disponibilizadas pelo Departamento de Justiça dos Estados Unidos. 


\subsection{O suposto cartel internacional dos compressores}

Além dos casos acima citados em que o Brasil pode ser visto com um beneficiário da cooperação, merece destaque a recente investigação envolvendo compressores em que o Brasil atuou conjuntamente com autoridades antitruste do Departamento de Justiça dos Estados Unidos e da Comissão Europeia na organização de busca e apreensões simultâneas realizadas em fevereiro de 2009 nas três jurisdições, revelando-se uma parceria inédita em termos de cooperação.

Tal investigação também se revela inédita eis que os indícios do suposto cartel foram identificados pela autoridade brasileira. Conforme descrito por Gaban e Domingues (2009, p. 284-285), a SDE, a Polícia Federal e o Grupo de Atuação Especial de Repressão à Formação de Cartéis e à Lavagem de Dinheiro e de Recuperação de Ativos (GEDEC), órgão do Ministério Público do Estado de São Paulo, deflagraram, em 17 de fevereiro de 2009, a denominada "Operação Zero Grau”, contra um suposto cartel de compressores (equipamentos utilizados no resfriamento de aparelhos como geladeira, ar-condicionado e bebedouro). A operação teve início no último trimestre de 2008 por iniciativa do Departamento de Proteção e Defesa Econômica.

As investigações foram iniciadas com a celebração de um acordo de leniência no Brasil tendo a autoridade brasileira verificado também a existência de evidências fora do Brasil, resultando nessa parceria inédita para a realização de busca e apreensão simultânea no Brasil, Estados Unidos, Alemanha, Dinamarca e Itália.

Após a realização de tais buscas e apreensões, foi instaurado o Processo Administrativo n. 08012.00820/2009-11 que atualmente encontra-se sob análise da SDE, para investigação de suposta conduta colusiva durante o período de 1996 a 2008. 


\section{Conclusão}

Enquanto os efeitos de um cartel internacional não respeitam qualquer limite de fronteiras territoriais, a extensão da aplicabilidade das leis antitruste nacionais enfrenta certos limites colocados pelo Direito Internacional.

Se a soberania e a independência estatais constituem os princípios sob os quais se desenvolve a liberdade do Estado no desempenho de sua jurisdição normativa em face de outros Estados, a exata extensão material do exercício da jurisdição extraterritorial do Estado está longe de ser considerada uma unanimidade.

Os Estados podem exercer sua jurisdição executiva extraterritorial sem que tal exercício seja considerado uma afronta à soberania da outra nação ou ao Direito Internacional, quando em nome da independência e soberania internacionais repercutidas pelo princípio da territorialidade. Sem dúvidas, tal princípio é o de maior importância e o mais aceito, já que tem enquanto seu elemento central de conexão o território, sendo certo que tal elemento se afigura enquanto o mais consistente e que, via de regra, prevalece em detrimento aos demais para a determinação da jurisdição do Estado $^{151}$.

Desta forma, verificou-se para o exercício da jurisdição extraterritorial do Estado, que o Direito Internacional prescreve princípios de cunho geral (tais como a igualdade entre os

\footnotetext{
151 "The received rule as to the territoriality of criminal law rests on a sound basis. The territorial sovereign has the strongest interest, the greatest facilities, and the most powerful instruments for repressing crimes, whether committed by native-born subjects or by domiciled aliens in his territory" (LEWIS, George Cornewall. Foreign Jurisdiction and the Extradition of Criminals, 1859, p. 30 apud HARVARD LAW SCHOOL, 1935, p. 483). Tradução livre: "A regra estabelecida quanto à territorialidade do direito penal repousa sobre uma base sólida. A soberania territorial possui o mais forte dos interesses e os mais poderosos instrumentos de repressão contra crimes, sejam ela cometido por indivíduos nativos ou estrangeiros domiciliados em seu território".
} 
Estados e o respeito à soberania de outra nação) e de cunho específico. Em relação a esses últimos, impende fazermos uma observação quanto ao fato de tais princípios terem sido inicialmente estabelecidos para aplicação exclusiva em jurisdição penal por meio de princípios norteadores para sua aplicação. Posteriormente, tiveram sua aplicação estendida às outras matérias, seja por aceitação da sociedade internacional, por exemplo, o princípio da universalidade, o qual é aplicado no âmbito dos Direitos Humanos, seja pela iniciativa unilateral de determinados Estados.

Notadamente na esfera do Direito Antitruste, como vimos no Capítulo II, há três critérios principais comumente utilizados pelas legislações de defesa da concorrência com o objetivo de determinar a jurisdição a ser exercida sobre determinada prática anticompetitiva: (i) territorialidade, (ii) nacionalidade dos agentes e (iii) local da verificação dos efeitos.

Se a competência dos Estados em reprimir práticas restritivas da concorrência praticadas em seu território é praticamente inquestionável, a controvérsia reside sobre a extensão extraterritorial do direito da concorrência aos acordos celebrados no estrangeiro que produzem efeitos no mercado interno, ou seja, na chamada doutrina dos efeitos originária dos Estados Unidos da América.

Muito embora nem todas as jurisdições concordem com a doutrina dos efeitos inaugurada pelos Estados Unidos da América, sendo certo que algumas delas sejam vigorosas e repetidamente tenham protestado a aplicação extraterritorial das leis estadunidense, a pesquisa conduzida com 42 jurisdições sobre a extraterritorialidade prevista em suas legislações de defesa da concorrência traz dois elementos fáticos bastante interessantes. $\mathrm{O}$ primeiro é que apenas Chile e Colômbia não dispõem de instrumentos de extraterritorialidade para aplicação de seu direito interno. O segundo é que dos 40 países que afirmaram se valer da extraterritorialidade em casos de cartel internacional 40 deles, ou seja, 100\%, adotam enquanto fundamento principal a teoria dos efeitos.

No que toca especificamente o Brasil, a Lei Antitruste Brasileira prevê expressamente sua aplicação extraterritorial em seu artigo $2^{\circ}$ caput. Com efeito, o legislador 
brasileiro adota expressamente o princípio da territorialidade contemplado no trecho "às práticas cometidas no todo ou em parte do território nacional" - que se refere ao local da atividade - e o princípio dos efeitos territoriais contemplado no trecho "ou que nele produzam ou possam produzir efeitos" - que se refere aos efeitos (efetivos ou potenciais) que tiveram local no Brasil. Vale lembrar que o legislador brasileiro optou por não qualificar quais efeitos são suficientes para legitimar a aplicação da jurisdição extraterritorial do Brasil.

Em relação ao grau de maturidade dos instrumentos de cooperação que se valem as autoridades brasileira de defesa da concorrência, vimos, no Capítulo III, que ainda há um grande percurso a ser trilhado pelo Brasil, pois, o país ainda se pauta nos acordos de primeira geração, o quais são instrumentos de cooperação muito rudimentares e característicos de instituiçõos que ainda não atingiram maturidade institucional para firmarem os acordos de segunda geração. Nenhum dos acordos firmados pelo Brasil prevê obrigações quanto ao fornecimento de informações confidenciais à outra parte e, na prática, o consentimento, quando é concedido, ocorre sob diversas condições e limitações. Como corrobora a assertiva exposta no documento enviado à OCDE pelas autoridades brasileiras de defesa da concorrência, "Our cooperation usually relates to the exchange of non-confidential information and general views on the case" (OCDE, 2012a).

Contudo, como visto, o CADE tem um papel de líder na América Latina na organização e participação das conferências que buscam incrementar o nível de maturidade das agências da região. Há, assim, boas razões para se acreditar que a cooperação entre o CADE e suas contrapartes estrangeiras está evoluindo a passos largos, em particular no cenário apresentado. Pode-se, assim, resumir esta evolução em três momentos. Um primeiro, até 2003, fase em que as instituições do CADE estavam ainda amadurecendo. O Brasil era exclusivamente receptor de assistência técnica, sendo esse papel ainda que passivo, de extrema importância para a contribuição do aperfeiçoamento do instrumental de aplicação das leis de defesa da concorrência no Brasil. De um lado, como se viu, durante os primeiros casos de cartéis internacionais enfrentados pelo CADE, as investigações brasileiras não receberam aporte documental dos órgãos estrangeiros os quais, inclusive, já haviam emitido decisões 
condenatórias sobre os casos. Do outro lado, vale destacar o empenho do CADE em tirar proveito do auxílio técnico e experiência oferecidos pelas suas agências-irmãs estrangeiras mais amadurecidas e das orientações das organizações multilaterais no sentido de edificar no seio da legislação antitruste brasileiras melhores técnicas investigativas e persecutórias aos cartéis. Esses lados são, não por acaso, as duas faces da mesma moeda. Não há cooperação estrangeira para fins de investigação de um cartel transnacional, como de fato não houve, sem antes haver confiança na solidez das instituições brasileiras de defesa da concorrência. Mérito do CADE, em particular da antiga SDE, que, neste primeiro momento, soube pavimentar o caminho para a conquista da confiança de suas contrapartes internacionais. Fortalecer seus instrumentos legais de investigação por meio da Lei n. 10.149/00, além de, por meio da advocacia da concorrência, promover interna e externamente as instituições brasileiras de defesa da concorrência contribuíram imensamente para essa pavimentação.

No segundo momento, período de 2003 a 2009, o CADE passou a colher os primeiros frutos do início de seu processo de consolidação institucional. Dispondo dos sofisticados instrumentos legais e priorizando seus recursos para o combate aos cartéis, passou a utilizá-los efetivamente nas investigações ${ }^{152}$. Também, formou fundamentais parcerias com a Polícia Federal, a Advocacia Geral da União, os Ministérios Públicos, Controladoria-Geral da União através da promoção da conscientização da importância da proteção do livre mercado também por esses órgãos do governo. Promoveu seu programa de leniência mundo à fora ${ }^{153}$. Não foi à toa que a partir de 2003 os primeiros acordos de leniência em caso de cartéis internacionais foram firmados. Também neste período, o CADE, como demonstrado acima,

\footnotetext{
152 Por exemplo, o número de mandados de busca e apreensão para obter provas de cartéis tem aumentado significativamente: de 2003 a 2005, 11 mandados foram cumpridos; em 2006, 19 mandados foram cumpridos; e, em 2007, 84 mandados foram cumpridos. Em 2008, outras 12 empresas suspeitas de participação no ilícito de cartel sofreram operação de busca e apreensão autorizada judicialmente. Em 2009, a SDE realizou quatro operações de busca e apreensão.

${ }^{153}$ No início de 2008, a SDE, tendo elaborado uma cartilha sobre o Programa de Leniência Brasileiro, realizou uma espécie de road show e entregou o documento aos grandes escritórios de advocacia internacionais. Cf. notícia do jornal $O$ Globo, de 15 fev. 2008.
} 
passou a ser, além de receptor, doador de assistência técnica, afirmando-se enquanto aspiração da categoria antitruste para suas agências-irmãs latino-americanas.

A partir de 2009, neste contexto de maior credibilidade institucional no contexto nacional e internacional, foi possível uma cooperação mais pareada entre o CADE e os órgãos de defesa da concorrência de outros países. Prova disso foi a "Operação Zero Grau” com o objetivo de apreender evidências relativas ao suposto cartel internacional no mercado de compressores. Foram cumpridos seis mandados de busca e apreensão de documentos nos Estados de São Paulo e Santa Catarina numa ação coordenação entre SDE, a Polícia Federal e o Grupo de Atuação Especial de Combate à Formação de Cartéis e à Lavagem de Dinheiro (GEDEC) do Ministério Público do Estado de São Paulo. Simultaneamente à operação no Brasil, o Departamento de Justiça dos Estados Unidos e a Comissão Europeia realizaram ações similares nos Estados Unidos e Europa (Itália e Dinamarca), sendo a primeira vez que as autoridades brasileiras participaram de ação conjunta com autoridades estrangeiras em caso de cartéis.

Sem dúvida, há um reconhecimento que transcende o território brasileiro do avançado estágio de maturidade do SBDC, sobretudo, do Programa Brasileiro de Combate a Cartéis.

Com efeito, o processo de cooperação entre as agências antitruste do mundo leva inexoravelmente a uma convergência global em termos de implementação de uma cultura mais homogênea da concorrência nos países do mundo. Essa convergência não pode significar a mera transposição do sistema de defesa da concorrência de um país que hoje goza de credibilidade a outro uma vez que isto poderia implicar a transposição - em nível mundial - de todos os fracassos que emergirem do sistema-modelo. Tampouco pode a convergência desconsiderar que cada país tem sua própria e distinta cultura jurídica, "uma ordenação de ideias, pensamentos e atitudes sobre o direito e instituições legais que conduz a um evidente problema de transferibilidade de institutos legais de uma cultura a outra" (SALLES, 1998, p. 29). 
Outra problemática que emerge trata-se de quão transparente e de quanto deve ser a cooperação entre as agências aos investigados. As autoridades antitruste brasileiras por lei e pela Constituição devem zelar pelas informações tidas como confidenciais e sensíveis das empresas e dos indivíduos sob investigação de prática anticompetitiva no território nacional. Também por lei e pela Constituição, devem salvaguardar em sua plenitude as garantias processuais dos investigados. O CADE, seja enquanto doador ou receptor de cooperação internacional, deve conciliar duas de suas obrigações, a de garantir o due processo of law aos investigados e a de proteger informações confidenciais relativas às empresas e ou aos indivíduos nos termos da legislação nacional.

Também, o CADE, ao estabelecer mecanismos de cooperação, não pode abdicar de duas perspectivas fundamentais, quais sejam, a ex parte principis - a preocupação do Estado com a governabilidade e com a manutenção de suas relações internacionais - e a ex parte populi - a perspectiva daqueles que estão submetidos ao poder e cuja preocupação é a liberdade, tendo como conquista os direitos humanos (ARAUJO, N. 2009, p. 98).

Enfim, como se viu, a cooperação internacional entre as agências antitruste emerge enquanto mecanismo fundamental para o imperativo combate ao cartel internacional. $\mathrm{O}$ diálogo entre as agências não pode e nem deve, ainda que sob a argumentação da solidariedade entre os Estados no plano internacional, esquecer-se da Justiça - mormente, das garantias individuais dos investigados. 


\section{Referências Bibliográficas}

ABBOTT, Kenneth W.; SNIDAL, Duncan. Hard and Soft Law in International Governance. In: International Organization, Cambridge: Cambridge University Press, 22 jun. 2000. Disponível em <http://www.accessmylibrary.com/article-1G1-65147526/hard-and-softlaw.html>. Acesso em 1 jul. 2010.

ACCIOLY, Hildebrando; SILVA, G. E. do Nascimento; CASELLA, Paulo Borba. Manual de Direito Internacional Público. 17. ed. Saraiva: São Paulo, 2010.

ALMUNIA, Joaquín. A new decade for the International Competition Network. In: Annual Conference of the International Competition Network, 10, 2011, The Hague. Speech... The Hague, ICN, 18 mai. 2011. Disponível em <http://europa.eu/rapid/pressReleasesAction.do?reference=SPEECH/11/346\&format=HTML \&aged $=0$ \&language $=E N \&$ guiLanguage $=e n>$. Acesso em: 7 jul. 2011.

ALMEIDA, José Gabriel Assis de. A Aplicação "Extraterritorial" do Direito da Concorrência. Revista do IBRAC, v. 8, n. 3, 2001.

AMERICAN BAR ASSOCIATION. Section of Antitrust Law. Report of the ABA Special Committee on International Antitrust. 1991. Disponível em: <http://www.americanbar.org/content/dam/aba/administrative/antitrust_law/report_1991_full_ report.authcheckdam.pdf>. Acesso em: 23 nov. 2012.

ANNUAL CONFERENCE OF THE INTERNATIONAL COMPETITION NETWORK, 6, 2007, Moscou. Co-operation between competition agencies in cartel investigations. Moscou: ICN, mai. 2007. Disponível em <http://www.internationalcompetitionnetwork.org/uploads/library/doc348.pdf>.

ARAUJO, Mariana Tavares de. The Brazilian Experience on International Cooperation in Cartel Investigation. Brasília: Secretaria de Acompanhamento Econômico, 2002. Documento de Trabalho, n. 21, nov./2002. Disponível em: http://www.seae.fazenda.gov.br/central_documentos/documento_trabalho/2002. Acesso em: 12 jul. 2010.

ARAUJO, Mariana Tavares de. Programa de Leniência e a Espiral Ascendente. In: IBRAC, 2007, Rio de Janeiro. Apresentação...Rio de Janeiro: IBRAC, 2007. Disponível em: http://portal.mj.gov.br/sde/data/Pages/MJ34431BE8ITEMID4022B1D525C3404A828D4F073 52CF1E1PTBRIE.htm. Acesso em: 25 jun. 2010

ARAUJO, Mariana Tavares de. Advocacia da Concorrência: A Experiência Brasileira. In: 9TH ICN ANNUAL MEETING, Turquia, 4, 2010. Apresentação...Turquia: ICN, 29 abr. 2010. Disponível em: http://portal.mj.gov.br/main.asp?ViewID=\%7BF13CE2B7-13C8-48EF8422-84E1DA1FFA23\% 7D\&params=itemID=\%7B4CEF9AA7-0EB5-408A-8EE6C8B98309ABC8\%7D;\&UIPartUID=\%7B2868BA3C-1C72-4347-BE11A26F70F4CB26\%7D. Acesso em: 21 dez. 2012. 
ARAUJO, Nádia. A importância da cooperação jurídica internacional para a atuação do Estado Brasileiro no plano interno e internacional. In: CARVALHO, André R.; CASELLA, P. B. (Orgs.). Direito Internacional: homenagem a Adherbal Meria Mattos. São Paulo: Quartier Latin, 2009.

AREEDA, Phillip E.; KAPLOW, Louis. Antitrust analysis: problems, texts, cases. 4. ed. Boston: Little, Brown and Company, 1988.

AREEDA, Phillip E.; TURNER, D. Antitrust law. Boston-Toronto: Little, Brown and Company, 1978.

AREND, Anthony Clark. Legal Rules and International Society. Oxford: Oxford University Press, 1999.

BAIN, Joe Staten. Barriers to New Competition. Cambridge: Harvard University Press, 1965.

BAKER, Jonathan B. A Preface to Post-Chicago Antitrust. In: VAN DEN BERGH, Roger; PARDOLESI, Roberto; CUCINOTTA, Antonio (ed.). Post-Chicago Developments in Antitrust Law. Londres: Edward Elgar, 2002.

BARNETT, Thomas O. Seven steps to better cartel enforcement. In: Annual Competition Law \& Policy Workshop, 11, 2006, Florença. Presentation... Florença: European Union Institute Florence, Italy. Disponível em <http://www.justice.gov/atr/public/speeches/216453.htm>. Acesso em: 20 jul. 2011.

BASTOS, Aurelio Wander. Cartéis e concorrência: estudo sobre a recuperação legislativa de conceitos de direito econômico no Brasil. Revista do Direito do Consumidor, v. 23/24 jul./dez. 1997.

BASTOS, Celso Ribeiro; MARTINS, Ives Gandra. Comentários à Constituição do Brasil. v. 1. 2. ed. São Paulo: Saraiva, 2000.

BOBBIO, Norberto. Teoria do Ordenamento Jurídico. Brasília: Editora Universidade de Brasília, 1991.

BONAVIDES, Paulo. Ciência Política, Rio de Janeiro, 7ª ed., Forense, 1988.

BOTTA, Marco. The Cooperation between the Competition Autorithies of the Developing Countries: Why does it not Work? Case Study on Argentina and Brazil. The Competition Law Review, v. 5, issue 2, p. 153-178, 2009.

BRASIL. Constituição (1934). Constituição da República dos Estados Unidos do Brasil . Rio de Janeiro, DF: Imprensa Nacional, 1935.

BRASIL. Constituição (1937). Constituição da República dos Estados Unidos do Brasil: decretada pelo presidente Getulio Vargas em 10 de novembro de 1937. Rio de Janeiro, DF: s.n., 1937.

BRASIL. Constituição (1946). Constituição da República dos Estados Unidos do Brasil . Rio de Janeiro, DF: s.n., 1946.

BRASIL. Lei n. 4.137, de 10 de setembro de 1962. Regula e repressão ao abuso do Poder Econômico. Diário Oficial [da] República Federativa do Brasil, Brasília, DF, 12 nov. 1962. 
Disponível em <http://www.planalto.gov.br/ccivil_03/leis/1950-1969/L4137.htm〉. Acesso em: 14 jul. 2011.

BRASIL. Constituição (1967). Constituição da República Federativa do Brasil . Brasília, DF: s.n., 1967.

BRASIL. Constituição (1988). Constituição da República Federativa do Brasil. Brasília, DF: Senado, 1988.

BRASIL. Lei $n$. 8.137, de 27 de setembro de 1990. Define crimes contra a ordem tributária, econômica e contra as relações de consumo, e dá outras providências. Diário Oficial [da] República Federativa do Brasil, Brasília, DF, 28 set. 1990. Disponível em <http://www.planalto.gov.br/ccivil_03/leis/L8137.htm>. Acesso em: 14 jul. 2011.

BRASIL. Lei $n$. 8.158, de 8 de janeiro de 1991. Institui normas para a defesa da concorrência e dá outras providências. Diário Oficial [da] República Federativa do Brasil, Brasília, DF, 9 jan. 1991. Disponível em <http://www.planalto.gov.br/ccivil_03/leis/L8158.htm>. Acesso em: 14 jul. 2011.

BRASIL. Lei n. 12.529, de 30 de novembro de 2011. Estrutura o Sistema Brasileiro de Defesa da Concorrência; dispõe sobre a prevenção e repressão às infrações contra a ordem econômica; altera a Lei no 8.137, de 27 de dezembro de 1990, o Decreto-Lei no 3.689, de 3 de outubro de 1941 - Código de Processo Penal, e a Lei no 7.347, de 24 de julho de 1985; revoga dispositivos da Lei no 8.884, de 11 de junho de 1994, e a Lei no 9.781, de 19 de janeiro de 1999; e dá outras providências. Diário Oficial [da] República Federativa do Brasil, Brasília, DF, 30 nov. 2001. Disponível em: <http://www.planalto.gov.br/ccivil_03/_Ato20112014/2011/Lei/L12529.htm>. Acesso em: 22 nov 2012.

BRASIL, Ministério da Justiça, CADE. Resolução n. 20, de 9 de junho de 1999. Dispõe, de forma complementar, sobre o Processo Administrativo, nos termos do art. 51 da Lei 8.884/94. Diário Oficial da União, Brasília, DF, 28 jun. 1999.

BRASIL. Medida Provisória 2.055-1, de 12 de setembro de 2000. Diário do Congresso Nacional, Brasília, DF, 10 out. 2000, p. 22724-22725

BRASIL, Supremo Tribunal Federal. Recurso em Habeas Corpus 79.785. Relator: Min. Sepúlveda Pertence. Data de Julgamento: 22 nov. 2002.

BRASIL, Ministério da Justiça, CADE. Processo administrativo - denúncia de formação de cartel - Mercado relevante: pedra britada. Processo Administrativo n. 08012.002127/2002-14. Relator: Conselheiro Luis Carlos Thadeu Delorme Prado. Brasília, 2003.

BRASIL, Ministério da Justiça, CADE. Processo administrativo - prática de acordo de preços por postos revendedores de combustíveis sob a influência do Sindicato do Comércio Varejista de Derivados de Petróleo e Lojas de Conveniência no Estado de Pernambuco - Mercado relevante: serviço de revenda de combustíveis - gasolina, álcool e diesel. Processo Administrativo n. 08012.003208/99-85. Relator: Conselheiro Fernando de Oliveira Marques. Brasília, 2 jun. 2004.

BRASIL, Ministério da Justiça, CADE. Processo administrativo - cartel internacional punido na Europa e nos Estados Unidos - Mercado relevante: vitaminas em geral. Processo Administrativo n. 08012.004599/1999-18. Relator: Conselheiro Ricardo Villas Bôas Cueva. Brasília, 2007. 
BRASIL, Ministério da Justiça, Secretaria do Desenvolvimento Econômico. Defesa da Concorrência. 2012. Disponível em: http://portal.mj.gov.br/main.asp?ViewID=\%7B34431BE8-99AE-426E-B569E0785B5AB1B8\%7D\&params=itemID=\%7BA9EA8F7D-13D2-49C1-BF0F20E752606414\%7D; \&UIPartUID=\%7B2868BA3C-1C72-4347-BE11-A26F70F4CB26\%7D. Acesso em: 12 out 2012.

CELLI JUNIOR, U. Direito da Concorrência no Mercosul. In: CASELLA, Paulo Borba (coord.). Contratos internacionais e direito econômico no Mercosul. São Paulo: Ltr, 1996.

CHAYES, Abram; CHAYES, Antonia Handler. The New Sovereignty: Compliance with International Regulatory Agreements, Cambridge, MA: Harvard University Press, 1995.

COMBACAU, Jean; SUR, Serge. Droit International Public. 4. ed. Paris: Montchrestien, 1999.

COMMISSION OF THE EUROPEAN COMMUNITIES. Competition Policy in the New Trade Order: Strengthening International Cooperation Rules, Brussels, 1995. Disponível em: <http://eurlex.europa.eu/LexUriServ/LexUriServ.do?uri=COM:1995:0359:FIN:EN:PDF>.

Acesso em: 21 dez. 2012

COMPARATO, Fábio K. O indispensável direito econômico. In: de direito empresarial. Rio de Janeiro: Forense, 1978, pp. 455-459. . Ensaios e pareceres

CONNOR, John M. Global Cartel Redux: The Amino Acid Lysine Antitrust Litigation (1996). West Lafayette: Purdue University, 2002. Disponível em: http://www.agecon.purdue.edu/staff/connor/papers/global_cartels_redux4.doc. Acesso em: 3 dez. 2010.

CONNOR, John M.; HELMERS, C. Gustav. Statistics on Modern Private International Cartels, 1900-2005. AAI Working Paper, Washington, DC, n. 07-01, jan. 2007. Disponível em <http://www.antitrustinstitute.org/files/567_020920070047.pdf>. Acesso em: 25 jun. 2010.

COPPEL, Jason. A Hard Look at the Effects Doctrine of Jurisdiction under Public International Law. Leiden Journal of International Law, Cambridge, Massachusetts, Estados Unidos da América, v. 6, n. 1, p. 73-90, 1993.

CORRÊA, Darwin Lourenço. Jurisdição Extraterritorial em Direito Antitruste. 2002. $240 \mathrm{f}$. Dissertação (Mestrado em Direito). Faculdade de Direito da Universidade de São Paulo, São Paulo, 2002.

CORTINA, Adela. Ética sin moral. Madrid: Tecnos, 1990.

CRETELLA NETO, José. Curso de Direito Internacional Penal. Ijuí: Editora Unijuí, 2008.

DALLARI, Dalmo de Abreu. Elementos de Teoria Geral do Estado. São Paulo: Saraiva, 1995. DINH, Nguyen Quoc; DAILLER, Patrick; PELLET, Alain. Direito Internacional Público. $2^{\mathrm{a}}$ ed. Lisboa: Fundação Calouste Gulbenkian, 2003.

DINIZ, Maria Helena . Curso de Direito Civil Brasileiro - Teoria Geral do Direito Civil. 21. ed. São Paulo: Saraiva, 2004. 
DOLINGER, Jacob. Direito Internacional Privado: parte geral. Rio de Janeiro: Renovar, 1996.

EVENETT, Simon. Síntesis del estudio preparado para el Grupo de Trabajo sobre La Interacción entre Comercio y Política de Competência. In: TALLER AVANZADO SOBRE COMERCIO Y POLÍTICA DE COMPETENCIA/ADVANCED WORKSHOP ON TRADE AND COMPETITION POLICY. 12, 2004, Brasília. Apresentação...Brasília: OMC, 2004

EVENETT, Simon J.; LEVENSTEIN, Margaret C.; SUSLOW, Valerie Y. International Cartel Enforcement: lessons from the 1990s. World Bank Policy Research Working Paper, Washington, DC, n. 2680, set. 2001. Disponível em < http://documents.worldbank.org/curated/en/2001/09/1614730/international-cartelenforcement-lessons-1990s\# >. Acesso em: 9 jun. 2007.

FARIA, Werter R. Constituição econômica, liberdade de iniciativa e concorrência. Porto Alegre: Fabris Ed., 1990.

FEKETEKUTY, G. \& ROGOWSKY, R. The Scope, Implication and Economic Rationale of a Competition Oriented Approach to Future Multilateral Trade Negotiations. In: ARNDT, A.; MILNER, C. The World Economy. Cambridge: Blackwell, 1996.

FERRAZ JUNIOR, Tércio Sampaio. Lei de defesa da concorrência, origem histórica e base constitucional. Arquivos do Ministério da Justiça, n. 180, jul./dez. 1992.

FINCKENSTEIN, Konrad Von. Core International Competition Issues in Canada. In: INTERNATIONAL COMPETITION POLICY ADVISORY COMMITTEE, 11, 1998, Washington, D.C. Speech... Washington, D.C, 2 nov. 1998. Disponível em: http://www.competitionbureau.gc.ca/eic/site/cb-bc.nsf/eng/00917.html. Acesso em: 28 jun. 2012.

FONSECA, João Bosco Leopoldino da. Lei de proteção da concorrência: comentários à legislação antitruste, Rio de Janeiro: Forense, 2001.

FORGIONI, Paula. Os fundamentos do antitruste. 1996. 369 f. Tese (Doutorado em Direito Econômico e Financeiro) - Faculdade de Direito, Universidade de São Paulo, 1996. . Os fundamentos do antitruste. 1. ed. São Paulo: Revista dos Tribunais, 1998. . Os fundamentos do antitruste. 2. ed. São Paulo: Revista dos Tribunais, 2005.

FOX, Eleonor M. International Antitrust and the Doha Dome. Virginia Journal of International Law, Charlottesville (VA), v. 43, 2003. Disponível em: cplaw.cupl.edu.cn/upload/05070100579562.pdf. Acesso em: 23 nov. 2012.

GABAN, Eduardo Molan. Acordos de leniência no Brasil (Lei n. 8.884/94). In: FRANCESHINI, José Inácio G.; MIRANDA, Custódio da P. U. (Org.). Direito Empresarial questões contemporâneas em coletânea. São Paulo: Singular, 2007, p. 35-45

GABAN, Eduardo M.; DOMINGUES, Juliana O. Direito Antitruste: O Combate aos Cartéis. 1. e 2. ed. São Paulo: Editora Saraiva, 2009.

GARNER, Bryan A. (ed.). Black’s Law Dictionary. 7. ed. St. Paul: West Group, 1999. 
GATT. The Results of the Uruguay Round of Multilateral Trade Negotiations. 1994.

GRAU, Eros Roberto. A Ordem Econômica na Constituição de 1988. 5. ed. São Paulo: Malheiros, 2000.

GRINOVER, Ada Pellegrini. Lineamentos gerais do novo processo penal na América Latina: Argentina, Brasil e o Código Modelo para Ibero-América. In: ARAÚJO JUNIOR. (org.). Ciência e política criminal em honra de Heleno Fragoso. Rio de Janeiro: Forense, 1992, pp. 33-55.

As garantias processuais na cooperação internacional em matéria penal. In: Revista Forense, Rio de Janeiro, v. 373, 2004, pp. 03-27.

HENKIN, Louis et al. International Law: cases and materials. 3.ed. St. Paul, West Publishing Co., 1993.

HOVENKAMP, Herbert. Federal antitrust policy: the law of competition and its practice. St. Paul: Thomson/West, 2005.

HUNGRIA, Nelson. Dos Crimes contra a Economia Popular. Rio de Janeiro: Livraria Jacinto, 1939.

. Comentários ao Código Penal. 3. ed. vol. I. Rio de Janeiro: Revista Forense, 1955.

IVO, Wilson Carlos Pereira; MAIA Camila Ieracitano M. Cooperação internacional entre autoridades antitruste brasileiras e estrangeiras. Migalhas. 2004. Disponível em <http://www.migalhas.com.br/mostra_noticia_articuladas.aspx?cod=8375>. Acesso em: 26 jun. 2010.

JAMES, Charles A. James. International Antitrust. In: 21st. Century: Cooperation and Converge, 2001. Paris. Speech... Paris, Fórum Global de Concorrência da OCDE, 17 out. 2001. Disponível em: http://www.oecd.org/dataoecd/62/57/2438935.pdf. Acesso em: 28.06.2010

KELSEN, Hans. Teoria Pura do Direito. Trad. João Batista Machado. 6. ed. São Paulo: Martins Fontes, 1998.

KHEMANI, R. Shyam (coord.). Diretrizes para Elaboração e Implementação de Política de Defesa da Concorrência. São Paulo: Singular, 2003.

KIRIAZIS, Georgios. Jurisdiction and cooperation issues in the investigation of international cartels. European Comission. 2001. Disponível em: < http://ec.europa.eu/competition/speeches/text/sp2001_010_en.pdf >. Acesso em: 24 ago. 2012.

KLEIN, Joe. Remarks Regarding the International Competition Policy and Advisory Committee. ICPAC, 27 nov. 1997. Disponível em $<$ http://www.usdoj.gov/atr/icpac/1294.htm>.

KOLANSKY, William. Global Competition Convergence and Cooperation: Looking Back and Looking Ahead. In: AMERICAN BAR ASSOCIATION FALL FORUM, Washington, D.C., 11, 2002. Speech... Washington, D.C.: American Bar Association Fall Forum, 7 jun. 2002. Disponível em: http://www.justice.gov/atr/public/speeches/200442.htm. Acesso em: 4 jul. 2010. 
KOSKENNIEMI, Martti. International law and hegemony: a reconfiguration. Cambridge (UK): Cambridge Review of International Affair, 2004.

KOVACIC, William E.; SHAPIRO, Carl. Antitrust policy: a century of economic and legal thinking. Journal of economic perspectives, v. 14, n. 1, inverno 2000.

KRATOCHWIL, Friedrich. Rules, Norms and Decisions - On the conditions of practical and legal reasoning in international relations and domestic affairs. Cambridge: Cambridge University Press, 1989.

HARVARD LAW SCHOOL. Research in International Law: Draft Convention on jurisdiction with respect to crime. The America Journal of International Law, v. 29, 1935.

LEWIS, George Cornewall. Foreign Jurisdiction and the Extradition of Criminals, 1859, p. 30 apud HARVARD LAW SCHOOL, 1935.

LOW, P.; SUBRAMANIAN, A. Beyond TRIMs: a case for multilateral action on investment rules and competition policy. In MARTIN, W.; WINTERS, A. (eds.), The Uruguay Round and the developing countries. Cambridge, U. K.: Cambridge University Press, 1996.

MACHADO, Maira Rocha. Cooperação penal internacional no Brasil: as cartas rogatórias passivas. In: Revista Brasileira de Ciências Criminais, São Paulo: RT, n. 53, mar./abr. 2005.

MAGALHÃES, José Carlos de. Aplicação extraterritorial de leis nacionais. Revista de Direito Público, São Paulo, v. 66, p. 63-80, 1983.

767, set. 1999.

Fatores de limitação da jurisdição do Estado. Revista dos Tribunais, São Paulo, v.

MAIA NETO, Cândido Furtado. Código de Direitos Humanos para a Justiça Criminal Brasileira. Rio de Janeiro: Forense, 2003.

Mann, Friedrich A. The doctrine of jurisdiction in International Law. Recueil des Cours de l'Académie de Droit International, v. 164, n. 1, 1964.

. The Doctrine of Jurisdiction in International Law. Oxford: Clarendon Press, 1973.

MARSHALL, Carla C. Panorama Geral da Defesa da Concorrência no Brasil. In: Revista IBRAC, São Paulo, v. 8, n. 4, 2001, p. 9-25.

MARTINEZ, Ana Paula. Jurisdição Extraterritorial em Direito da Concorrência: Balanço e Perspectivas. Revista de Direito Internacional e Econômico, Ano II, n. 10, jan/fev/mar/2005, p. 88.

MAZZUOLI, Valério de Oliveira. Tratados Internacionais de Direitos Humanos e Direito Interno. São Paulo: Saraiva, 2010.

MEESEN, Karl M. (ed.). Extraterritorial jurisdiction in theory and practice. Dresden: Kluwer Law International, 1996.

MEIRELLES, Hely Lopes. Direito Administrativo Brasileiro. 17. ed. São Paulo: Malheiros, 1992.

MELLO, Celso de Albuquerque. Curso de Direito Internacional Público. 15. ed. Rio de 
Janeiro: Renovar, 2007, v. 1.

MESTIERI, João. Teoria elementar de direito criminal: parte geral. Rio de Janeiro: edição do autor. 1990.

MIAJA DE LA MUELA, Adolfo. Introducción al Derecho Internacional Público. 6. ed. Madri: Gráficas Yagües, 1974, v. 1.

MIRABETE, Julio Fabbrini. Código de Processo Penal Interpretado. 11. ed, São Paulo: Ed. Atlas, 2004.

MIRANDA, Pontes de. Tratado de direito internacional privado. Rio de Janeiro: José Olympio, 1935.

MIRANDA, Pontes de. Comentários à Constituição de 1946. v. 4. 2. ed. São Paulo: M. Limonad, 1953.

MONTINI, Massimiliano. Globalisation and International Antitrust Co-operation. FEEM Working Paper No. 69.99, 1999. Disponível em <http://ssrn.com/abstract=200611 or http://dx.doi.org/10.2139/ssrn.200611>. Acesso em 3 jan 2013.

NASSER, Salem Hikmat. Fontes e formas do direito internacional: um estudo sobre a soft law. São Paulo: Atlas, 2005.

NEREP, Erik. Extraterritorial control of competition under International Law. Estocolmo, Norstedt \& Söners Förlag, 1983, v. 2.

NUSDEO, Fábio. Fundamentos para uma codificação do direito econômico. São Paulo: Revista dos Tribunais, 1995.

. Curso de economia introdução ao direito econômico. 3. ed. São Paulo: Revista dos Tribunais, 2001.

OCDE. Revised recommendation of the Council Concerning Cooperation between Member countries on Anticompetitive Practices affecting International Trade. C(95)130/FINAL, 1995. Disponível em: $<$ http://www.oecd.org/regreform/liberalisationandcompetitioninterventioninregulatedsectors/2 1570317.pdf>. Acesso em: 3 jan. 2013.

. Main Features of the Multilateral Agreement on Investment. DAFFE/MAI(98)4, 1997. Disponível em: <www.oecd.org/daf/mai/pdf/ng/ng984e.pdf>. Acesso em: 21 dez. 2012

Report of the OECD Committee on Competition Law And Policy: Making International Markets More Efficient Through "Positive Comity" In Competition Law Enforcement. DAFFE/CLP(99)19, $1999 . \quad$ Disponível em: <http://www.oecd.org/dataoecd/40/3/2752161.pdf>. Acesso em: 1 jul. 2010.

. Hard Core Cartels - Recent Progress and Challenges Ahead. Paris: OECD, 2003.

. Competition Committee. Best practices for the formal exchange of information between competition authorities in hard core cartel investigations. DAF/COMP(2005)25/FINAL, 16 nov. 2005. Disponível em <http://www.oecd.org/dataoecd/1/33/35590548.pdf>. Acesso em: 10 jul. 2010. 
. Lei e Política de Concorrência no Brasil: Uma Revisão pelos Pares. 2010.

. Improving International Co-Operation In Cartel Investigations Contribution from

Brazil - Session II. DAF/COMP/GF/WD(2012)32, 2012a.

. Report on the Nature and Impact of Hard Core Cartels and Sanctions against Cartels

under National Competition Laws. 9 abr. 2012b. Disponível em <http://www.oecd.org/competition/cartelsandanti-competitiveagreements/2081831.pdf>.

Acesso em: 03 jan. 2013.

OLIVEIRA, Gesner; RODAS, João Grandino. Direito e economia da concorrência. São Paulo: Renovar, 2004.

PAPADOPOULOS, Anestis. Bilateral Enforcement Cooperation Agreements. In: MARSDEN (ed.). Handbook of Research in Trans-Atlantic Antirust. Cheltenham, UK and Northampton, MA, USA: Edward Elgar, 2006.

PARISI, John J. Enforcement Cooperation Among Antitrust Authorities. In: Sixth Annual London Conference on EC Competition Law, 1999, London, England. Apresentação... London, $\quad$ England, $1999 . \quad$ Disponível em: http://www.ftc.gov/speeches/other/ibc99059911update.shtm. Acesso em: 28 jun. 2010.

PERMANENT COURT OF INTERNATIONAL JUSTICE. S.S. Lotus (Fr. v. Turk.), 1927 P.C.I.J. (ser. A) No. 10 (Sept. 7). Publications of the Permanent Court of International Justice, Series A, n. 10. Collection of Judgments, A.W. Sijthoff's Publishing Company, Leyden, 1927. Disponível em: <http://www.worldcourts.com/pcij/eng/decisions/1927.09.07_lotus.htm>. Acesso em: 13 jun. 2012.

PETERSMANN, Ernst-Ulrich. Competition-oriented Reforms of the WTO World Trade System - Proposals and Policy Options. In: ZÄCH, Roger (ed.). Towards WTO Competition Rules: Key Issues and Comments on the WTO Report (1998) on Trade and Competition. The Hague: Kluwer Law International, 1999, pp. 48-53.

POSNER, Richard. The Chicago School of Antitrust Analysis. University of Pennsylvania Law Review, Philadelphia, v. 127, n. 4, abr. 1979, pp. 925-948. . Law, pragmatism and democracy. Harvard: Harvard University Press, 2003.

REZEK, José Francisco. Direito Internacional Público. Curso Elementar. 4. ed. São Paulo: Saraiva, 1994.

RODAS, João Grandino. Jus Cogens. Revista da Faculdade de Direito da Universidade de São Paulo, São Paulo, v. 69, n. 2, 1974.

RODAS, João Grandino. Sociedade Comercial e Estado. São Paulo: Editora Unesp, 1995.

RODRIGUES, Manuel Coelho. A Extradição no Direito Brasileiro e na Legislação Comparada. Tomo I. Rio de Janeiro: Imprensa Nacional, 1930.

ROSENBERG, Barbara; BERARDO, José Carlos da Matta. Brazil: Cartels and Leniency. The Antitrust Review of the Americas 2007. Global Competition Review, London (UK), Special Report, 2006. Disponível em: 
http://www.bmalaw.com.br/nova_internet/arquivos/Artigos/Brazil_Cartels_and_Leniency200 7.pdf. Acesso: 21 de dez de 2012

ROSENTHAL, Douglas E.; KNIGHTON, William M. National laws and international commerce: the problem of extraterritoriality. Londres: Routledge \& Kegan Paul, 1982.

ROUSSEAU, J.-J. O Contrato Social. Tradução Antônio de Pádua Danesi. 3. ed. São Paulo: Martins Fontes, 1996.

SALGADO, Lucia Helena. A economia política da ação antitruste. São Paulo: Singular, 1997.

SALLES, Carlos Alberto de. Execução judicial em matéria ambiental. São Paulo, Revista dos Tribunais, 1998.

SALOMÃO FILHO, Calixto. Regulação da Atividade Econômica: princípios e fundamentos jurídicos. São Paulo: Malheiros, 2001.

SALOP, G. Practices that (credibly) facilitate oligopoly coordination. In: STIGLITZ, J.; MATHEWSON, F. (ed.). New Developments in the Analyzis of Market Structure. Cambrigde: MIT Press, 1986.

SANTOS, Karla Margarida Martins. Cartéis Internacionais - Uma abordagem dos mecanismos extraterritoriais de persecução. São Paulo: LTr, 2007.

SCHREUER, Christoph. The significance of International Organizations in current International Law. In: Law and State - a biannual collection of recent german contributions to these fields, vol. 38. Tubigen: Institute for Scientific Co-operation, 1988.

SCHUARTZ, Luis Fernando. Abuso de poder econômico e (i)legitimidade. Revista de Direito Mercantil, Industrial, Econômico e Financeiro, São Paulo, n. 95, jul./set. 1994.

Ilícito Antitruste e Acordos entre Concorrentes. Revista de Direito Mercantil, Industrial, Econômico e Financeiro, São Paulo, n. 124, out./dez. 2001, pp. 47-71.

SEIDL-HOHENVELDERN, Ignaz. Völkerrechtliche Grenzen bei der Anwendung des Kartellrechts. Aussenwirtschaftsdienst des Betriebs-Beraters, 1971.

SILVA, José Afonso da. Comentários à Constituição do Brasil. v. 7. São Paulo: Saraiva, 1990.

SILVA, Valéria Guimarães de Lima. Jurisdição Extraterritorial no Direito da Concorrência e a Ordem Internacional Contemporânea. 2004678 f. (Doutorado em Direito). Faculdade de Direito da Universidade de São Paulo, São Paulo, 2004.

SISTEMA DE INFORMAÇÃO SOBRE COMÉRCIO EXTERIOR. Dicionário de Termos de Comércio. Política de Concorrência. SICE, 2012. Disponível em <http://www.sice.oas.org/dictionary/CP_p.asp>. Acesso em 12 out 2012.

SLAUGHTER, Anne-Marie. Sovereignty and Power in a Networked World Order. Stanford Journal of International Law, Stanford (USA), v. 40, n. 2, 2004.

SOARES, Guido Fernando Silva. Uma Reavaliação Atual das Fontes do Direito Internacional: A Questão do "Jus cogens" e a "Soft law". In: __ Curso de Direito Internacional Público. 1. v. São Paulo: Atlas, 2004. 
SOKOL, D. Daniel. Monopolists without Borders: The Institutional Challenge of International Antitrust in a Global Gilded Age. Berkeley Business Law Journal, vol. 4.1, 2007.

SPRATLING, Gary. Negotiating the waters of International Cartel Prosecutions Agreements in International Cases. In: Annual National Institute on White Collar Crime conference, 13, 1999, São Francisco. Speech... São Francisco, ABA's Criminal Justice Section, 4 mar., 1999 . Disponível em: <http://www.justice.gov/atr/public/speeches/2275.htm >. Acesso em: 3 jun. 2007.

STERN, Brigitte. Conclusions. L'application extraterritoriale du droit économique, Cahiers du CEDIN, Paris, Montchrestien, 1987.

THORSTENSEN, Vera. A OMC - Organização Mundial do Comércio e as negociações sobre investimentos e concorrência. Revista Brasileira de Política Internacional, Brasília, v. 41, n. 1, 1998.

TOWNSEND, James B. Extraterritorial antitrust: the Sherman Antitrust Act and U.S. abroad. Colorado: Westview Press, 1980.

U.S. DEPARTMENT OF JUSTICE. Antitrust Division. International Competition Policy Advisory Committee. Final Report to the Attorney General and Assistant Attorney General for Antitrust. Washington, DC: U.S. Department of Justice, 2000. Disponível em <http://www.justice.gov/atr/icpac/finalreport.html>. Acesso em: 7 jul. 2011.

. The federal Trade Commission. Antitrust Enforcement Guidelines for International Operations, 1995. Disponível em: <http://www.justice.gov/atr/public/guidelines/internat.htm>. Acesso em 18 jun. 2012.

UNITED NATIONS CONFERENCE ON TRADE AND EMPLOYMENT, 1947-48, Havana. Havana Charter for an International Trade Organization. Havana, UNO, 24 mar. 1948. Disponível em <http://www.worldtradelaw.net/misc/havana.pdf $>$. Acesso em: 3 jul. 2010.

UNITED NATIONS CONFERENCE ON TRADE AND EMPLOYMENT. World Investment Report, Transnational Corporations, Market Structure and Competition Policy. 1997.

VALLADÃO, Haroldo. Da cooperação internacional em processos criminais. In: Revista dos Tribunais, São Paulo, vol. LXXXVII, fascículo 400, 1933.

VISCUSI, W. Kip; VERNON, John M.; HARRINGTON, Joseph E. Economics of regulation and antitrust. Cambridge: MIT Press, 2005.

VIRALLY, Michel. Annuaire de l'Institut de Droit International. Paris: Editions A. Pedone, v. 60, t. I., 1984. In: MENEZES, Wagner (coord.). A "soft law" como fonte do direito internacional. Direito internacional no cenário contemporâneo. Curitiba: Juruá, 2003

WHISH, Richard; BAILEY, David. Competition law. 5. ed. Oxford: Oxford University Press, 2005.

WTO MINISTERIAL CONFERENCE, 5, 2003, Cancun. Draft Cancún Ministerial Text. Cancun: WTO, 13 set. 2003. Disponível em <http://www.wto.org/english/thewto_e/minist_e/min03_e/draft_decl_rev2_e.htm>. Acesso 
em: 3 jul. 2010.

WTO MINISTERIAL CONFERENCE, 6, 2005, Hong Kong. Ministerial Declaration. Hong Kong: $\quad$ WTO, 18 dez. $2005 . \quad$ Disponível em <http://www.wto.org/english/thewto_e/minist_e/min05_e/final_text_e.htm>. Acesso em: 3 jul. 2010. 